\title{
EDSON GOMES
}

CONFORMABILIDADE PLASTICA DOS METAIS PELA MECANICA DA FRATURA NAO-LINEAR

TESE APRESENTADA A ESCOLA POLITECNICA DA UNIVERSIDADE DE SÃo PAUlo, PARA OBTENČ̃o DO TÍTULO DE DOUTOR EM ENGENHARIA.

SÃo PAULO, 1990

CONSULTA

ET -580 


\title{
EDSON GOMES
}

Engenheiro Mecânico, Universidade Estadual de Campinas, 1975 Mestre em Reatores Nucleares, Instituto de Pesquisas Energéticas e Nucleares-Universidade de são Paulo, 1978

\author{
CONFORMABILIDADE PLÁSTICÁ DOS METAIS
}

PELA MECÂNICA DA FRATURA NÃO-LINEAR

\begin{abstract}
Tese apresentada à Escola Politécnica da Universidade de são Paulo, para obtenção do titulo de Doutor em Engenharia.
\end{abstract}

\begin{abstract}
Orientador: Prof.Dr. ETTORE BRESCIANI FILHO
Professor Credenciado na Pós-Graduação, Escola Politécnica da Universidade de são Paulo

Professor Titular, Faculdade de Engenharia Mecânica da Universidade Estadual de Campinas
\end{abstract}

São Paulo, 1990 


\section{AGRADECIMENTOS}

Quero registrar o meu especial agradecimento ao Professor Doutor Ettore Bresciani Filho, orientador desta tese de doutorado e amigo. Tambem quero agradecer a Professora Doutora Cecilia Amélia de Carvalho Zavaglia que contribuiu de modo decisivo para a conclusão desta tese e ao eterno amigo Professor Fernando Antonio da Costa Nery pelo apoio e paciência durante este longo periodo de convivência mútua na EPUSP.

Agradeço tambem às seguintes pessoas $e$ instituições que de algum modo contribuirâf para a realização deste trabalho: ao Professor Doutor Valter Francisco Arruda Alves da EPUSP; ao Professor Doutor Carlos C. Tu; da EPUSP; ao Professor Doutor Giorgio E.O. Giacaglia, da EPUSP; ao Professor Doutor Roberto Y. Hukai, do IEE-USP; ao Professor Doutor José Maria S. Jarbado, da EESC-USP; ao Professor Assistente Gilmar Ferreira Batalha, da EPUSP; ao Professor Doutor Francisco Emílio Baccaro Nigro, da EPUSP e do IPT; ao Professor Doutor Itamar Ferreira, da UNICAMP; ao Professor Doutor Célio Tanigushi, da EPUSP; ao Professor Assistente Emilio Del Moral Hernandez, da EPUSP; ao Professor Assistente Antonio Carlos Seabra, da EPUSP; ao Professor Doutor Normonds Allen, da EPUSB; às Srtas. Cecília Maria da Costa Souza e Maria Lúcia Salata, da BICENGE; à srta. Thelma Lúcia Guedes Camelo, da ABLA; à srta. Ivan Rocha da silva, da EPUSP; ao sr. Donato João Binelli, da EPUSP; à Srta. Anita Leocádia Mokrejs, da UNESP; à Srta. Leila Funk Abraão, do IME da USP; aos engenheiros Mamiro Yoshizawa, e cláudio Antonio scarpinella, especialistas da CESP; ao Sr. Ayrton Roberto Mazzucato Leal da, EPUSP; ao Sr. 
Nelson Gomes de Moraes, da EPUSP; ao Professor Doutor Rubens Murillo Marques ,Presidente da Fundação Carlos Chagas; ao Professor Doutor Hélio Mitio, da EPUSP; ao Professor Doutor Marco Antonio Brinati, da EPUSP; ao Professor Doutor Eugénio da Motta Singer, da UNICAMP; ao especialista em energia Antonio Carlos Daniek, da CESP; à analista de computação Rosemary Nowak, do CCE da USP; ao analista de computação Francisco Marcos Dias, da ITAUTEC; ao analista de computação Lucas da costa Manso, da EMPIASA; à Sra. Neide de Souza Goes, às Srtas. Cristiane Alves de Souza e Silvana Bentley Murbak, aos técnicos Álvaro Mercatelli e Oswaldo Sanches Jr,todos do IPT: ao especialista em energia Elio Takashi Kumoto, da CESP; à Srta. Elizabeth Noto, da Secretaria de Defesa do Consumidor do Estado de São Paulo; ao Comandante Luiz Victor seize, Professor do Colégio Naval; às bibliotecárias Silvia Lúcia Ribeiro e Ademir do Carmo Merlin Barroso, da EPUSP; e ao Prof. Dr. Luiz Novaes Ferreira, da EPUSP.

Registro o meu especial agradecimento à FAPESP, à FINEP, à CAPES, ao IPEN (antigo IEA), à Faculdade de Engenharia Mecânica da UNICAMP, ao Departamento de Engenharia Mecânica da EPUSP, ao IPT, à Sra. Elizabete Pessine, do IPEN, ao Especialista da CESP Roberto Pessine e à Comissão de Pós-Graduação da Escola Politécnica da Universidade de São Paulo.

As minhas homenagens póstumas são para o Professor Doutor Rômulo Ribeiro Pieroni, do IEA, e ao engenheiro pesquisador Paulo Evaristo da Silva Chaves, do IPT. 


\section{RESUYO}

Este trabalho visa modelar e estabelecer procedimentos experimentais para permitir a construção de mapas de conformabilidade plástica dos metais fundamentados na mecânica da fratura não-linear elasto-plástica. Un critério de conformabilidade plástica foi desenvolvido pela utilização de uma integral invariante generalizada baseada no teorema de NOETHER das integrais invariantes. Discute-se tambem as limitações da teoria da plasticidade que impossibilitam a obtenção de critérios de conformabilidade por seu intermédio. É um importante objetivo proporcionar o surgimento de uma metodologia de ensaio contendo alto rigor técnico mas sendo de baixo custo $e$ de fácil implementação em simples instalações industriais. 0 procedimento foi aplicado no estudo do caso do forjamento a frio em matriz aberta, simulado por ensaio de compressão em prensa hidráulica. 


\begin{abstract}
The present study is aimed to the development of a low cost, to be implemented with ease, and technicality satisfactory industrial type testing for metal forming workability analysis. It is concerned with the development of an experimental procedures to permit the building up the metal forming workability maps, based on the nonlinear elastic-plastic fracture mechanics. A generalized nonlinear fracture mechanics invariant integral was applied to the case problem of the cold forging in flat open die of a ductile metalic material. At end a fracture criterion was developed in order to be possible the construction of the fracture deformation maps of the case study.
\end{abstract}




\section{INDICE}

SIMBOLOGIA

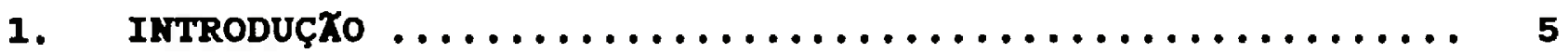

1.1. Teoria da Plasticidade dos Metais ............. 5

1.2. Mecânica da Fratura Linear e Não-Linear .......... 19

1.3. Conformação Plástica dos Metais .............. 31

1.4. Conformabilidade Plástica dos Metais ........... 36

Referências Bibliográficas ................... 40

2. ESTABELECIMENTo do PROBLEMA .................. 53

2.1. Definições $\ldots \ldots \ldots \ldots \ldots \ldots \ldots \ldots \ldots \ldots \ldots \ldots \ldots \ldots \ldots \ldots \ldots$

2.2. o Problema ........................... 54

2.3. Objetivos do Presente Trabalho .............. 54

2.4. Justificativa ....................... 55

Referências Bibliográficas $\ldots \ldots \ldots \ldots \ldots \ldots \ldots \ldots \ldots \ldots$

3. MECANICA da CONFORMaçT̃o PLÁstica dos metais .......... 54

3.1. Conceitos Fundamentais ................. 58

3.1.1. Comportamento dos Metais na Conformação ...... 63

3.1.2. Relações da Plasticidade dos Metais na ........ 65

3.1.3. Relações Experimentais de Tensões

versus Deformaçōes: LUDWICK, HOLLOMON,

VOCE, SWIFT, RAMBERG-OSGOOD e PRAGER .......... 69

3.1.4. A questão da anisotropia na Plasticidade........ 71

3.2. Teoria Geral da Plasticidade na

Conformação Plástica dos Metais .............. 73

3.2.1. Sistemas de Coordenadas Generalizadas

Sistema de LAGRANGE e de EULER,

Tensões de CAUCHY, LAGRANGE e de

KIRCCHOFF ....................... 73 
3.2.2. Sistemas de Equações para Problemas de

Conformação Plástica dos Metais .............

3.3. Métodos de Resoluções de Problemas

Elasto-plásticos ..................... 94

3.4. Método Variacional na Elasticidade e na

Plasticidade .......................... 95

3.4.1. Teoremas Gerais da Formulação Variacional ....... 96

3.4.2. Método de HILL do Trabalho Plástico ........... 100

3.4.3. Método dos Limites de PRAGER ............... 104

3.4.4. Aplicações dos Teoremas dos Valores Extremos

na Conformação Plástica dos' Metais .......... 109

3.5. Mecânica da Interação entre superficies

em Contato na Conformação Plástica:

fenômeno do atrito ..................... 112

Referências Bibliográficas $\ldots \ldots \ldots \ldots \ldots \ldots \ldots \ldots \ldots \ldots \ldots$

4. MECANICA DA FRATURA NTO-LINEAR E AS INTEGRAIS

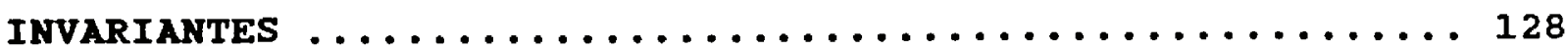

4.1. Fundamentos da Mecânica da Fratura

Linear e Não-Linear ..................... 128

4.2. Teorema de NOETHER para as Integrais

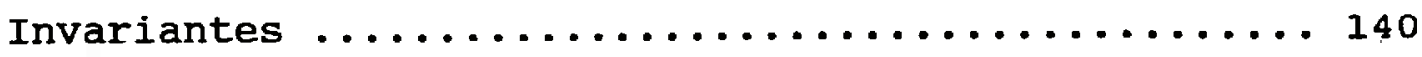

4.3. Integrais Iñváriantes e a Mecânica da

Fratura Não-Linear ..................... 141

Referências Bibliográficas ................... 158

5. CONFormabilidade PLASTICA dos metais PELA MecAnica

DA FRATURA NAO-LINEAR ..................... 162

5.1. Conceitos de Conformabilidade Plástica dos

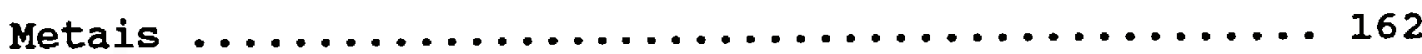


5.1.1. Conformabilidade Baseada no Conceito

Microscópico de Fratura Dúctil .............. 162

5.1.2. Conformabilidade Baseada no Conceito

Macroscópico de Deformação Plástica ............ 164

5.1.3. Desvantagens e Vantagens dos critérios de

Conformabilidade Variantes: baseados na

fratura dúctil e na deformação plástica

dos metais ........................... 165

5.2. Campos da Elasto-Plasticidade Gerados por

Integrais Invariantes da Mecânica da Fratura

Não-Linear ........................... 167

5.3. Conformabilidade Plástica dos Metais pela

Mecânica da Fratura Não-Linear .............. 181

Referências Biblioğráficas ................... 188

6. DESEHVOLVIMENTO EXPERIMENTAL ................... 191

6.1 Considerações Iniciais .................... 191

6.2 Material para os Ensaios............................

6.3 Determinação das expressões da Relação Tensão vs

Deformação............................. 195

6.4 Determinação do Coeficiente de Atrito e das Cargas de Compressão ............................. 198

6.5 Ensaios de Conformabilidade ................. 203

Referências Bibliográficas..................... 209

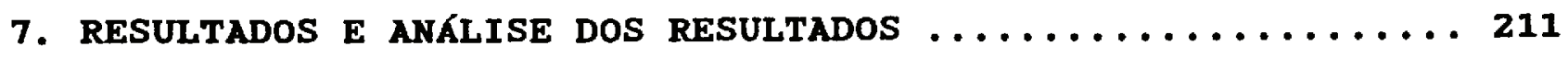

Referências Biblioggráficas.................... 224

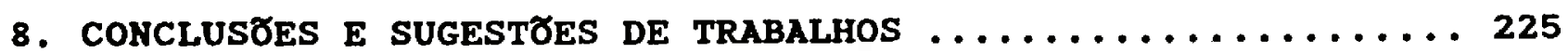

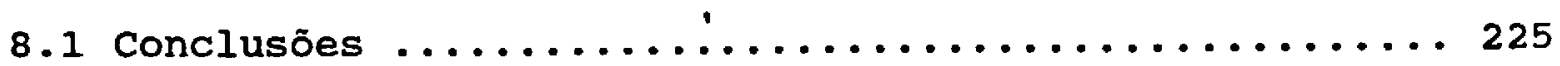

8.2 Sugestões de Trabalhos .................... 225 


\section{APANDICE}

Referência Bibllográfica 


\section{SIMBOLOGIA}

a; semi comprimento de trinca

$a, b, n$; parámetros na fórmula de vOCE

a, c, ni parámetros na fórmula de SWIFT

$A, \alpha, n$; constantes materiais ajustáveís

$A_{0}, A_{f}$; áreas inicial e final .

b. $\underline{B}$; vetores binormais

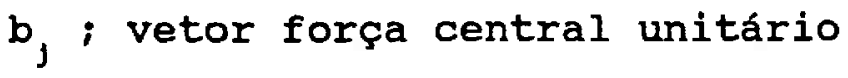

$a_{n}$; parâmetro relacionado à abertura de trincas

$d \underline{\varepsilon}^{\mathrm{P}}$; vetor incremental de deformação

de $\varepsilon_{1 j}$; deformação incremental total

d $\varepsilon_{1 j}^{0}$; deformação incremental elástica

$\mathrm{d} \varepsilon_{1\}}^{\mathrm{p}}$; deformação incremental plástica

Do ; fator de frequência relacionado ao coeficiente de difusão

D ; regiāo externa a uma trinca de RICE

$\frac{\mathrm{D}}{\mathrm{Dt}}\{\ldots\}$; derivada material em coordenadas materiais

62

$\frac{\partial}{\partial t}\{\ldots\} ;$ derivada parcial

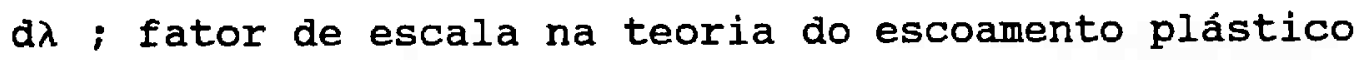

E ; energia total transferida para uma região de fratura

E ; módulo de Young para material elástico

$e_{1 \mathrm{jk}}, \varepsilon_{1 \mathrm{mn}}$; símbolos permutadores alternantes

e ; densidade de energia interna

$f_{\mathrm{XH}}\left(\sigma_{1 j}\right)$; função superfície de escoamento de HENCKY-VON MISES $f\left(\sigma_{1,}, k^{2}\right)$; superficie de escoamento

$f(s)$; função de parâmetros microestruturais

$f_{1}$; força de campo por̀ unidade de volume

grad $(\phi)$; vetor função gradiente da função $\phi(x)$ 
$g^{11}$; tensor métrico Euclidiano no sistema $x_{1}$

$g_{1 j}$; tensor métrico Euclidiano no sistema $x_{1}$

$G$; módulo de KIRCHHOFF para o cisalhamento

$g\left(\sigma_{1}, \mathrm{x}^{2}\right) ;$ potencial plástico generalizado

$\mathrm{H}$; constante de encruamento na expressão de LUDWICK

$\mathrm{h}$; espessura da película lubrificante

$I_{2}\left(S_{1,}\right)$; segundo invariante do tensor das tensões reduzidas

$I_{n}$; expressão integral constante para determinação da integral-J

$J$; integral-J de RICE

$\hat{\mathrm{J}}_{k}$; generalização da integral-J translacional

$K$; na expressão $F\left(\sigma_{1,}, \varepsilon_{1,}^{p}, W^{p}, T, K^{2}\right)=0$, é o critério de plasticidade

$\mathrm{k}$; constante de BoLtzManN na expressão de energia de ativação

$K$; coeficiente da expressão de HOLLOMON para resistência plástica

$\mathrm{K}, \mathrm{N}, \mathrm{p}$ ou $\mathrm{n}$; parâmetros de RAMBERG-OSGOOD

$\mathrm{K}$; fator de intensidádé de tensão perto da ponta de uma trinca

k ; energia cinética por unidade de massa

1 ; comprimento de arco numa curva envolvendo a trinca

$\hat{\mathrm{L}}_{\mathbf{k}}$; generalização da integral-L rotacional

m ; fator de atrito constante

m ; sensibilidade à taxa de deformação

$\hat{M}_{k}$; generalização da integral-M de expansão auto-similar

$\mathrm{n}$; expoente de encruamento nas expressōes de HOLLOMON e LUDWICK

$n_{k}, n_{j} ;$ vetores normais unitários

$\underline{\mathrm{n}}, \underline{\mathrm{N}}$; vetores normais

p ; pressão externa aplicada ao sistema material

p ; expoente na expressão de RAMBERG-OSGOOD

$Q$; energia de ativação

$R$; constante universal dos gases

$R A$; fator de redução de área 
$r$; distancia radial de um ponto afastado da ponta da trinca $s_{1 j}$; tensor de tensáo de KIRCHHOFF

$s_{11}, \sigma_{11}^{\prime} ;$ tensores das tensões reduzidas

$\mathrm{T}_{\text {fusaro }}$; temperatura de fusão

$T_{11}$; tensor de tensão de IAGRANGE

$T$; temperatura absoluta

$t, \underline{T}$; vetores, tangenciais

$t_{1}$; vetor de tração

$U$; energia potencial elástica

ù : taxa de deslocamento relativo, velocidade de evolução

ü ; aceleração

$u_{1}$; deslocamento relativo no sistema $x_{1}$

$\mathrm{U}_{1}$; deslocamento relativo no sistema $\mathrm{x}_{1}$

$\mathrm{V}$; volume do material envolto por uma superficie $\mathrm{S}$

$\underline{\text { i }}$; vetor velocidade

$\mathrm{v}_{1}$; campo de velocidades

$\mathrm{x}_{1}$; sistema de coordenadas materiais de LAGRANGE

$x_{1}$; sistema de coordenadas geométricas'de EULER

$z_{k}$; parâmetro de zENNER-HOLLOMON

$W^{p}$; densidade da energia de deformação

$\mathrm{w}_{\text {, }} \Delta \mathrm{v}$; velocidade relativa

W ; trabalho fornecido para um sistema

$W\left(\varepsilon_{11}\right)$; densidade de energia de deformação

$\alpha, \mathrm{n}$; parâmetros da expressão de RAMBERG-OSGOOD

$\delta\{\ldots\}$; primeira variação

$\hat{\delta}$; abertura da trinca relacionada à integral- $\hat{J}$

$\delta_{11}$; função delta de KRONECKER

$\delta_{t}$; deslocamento da abertura da trinca

$\Delta \mathrm{H}_{k}$; energia de ativação verdadeira 
$\varepsilon_{\text {oq }} ;$ deformação equivalente

$\varepsilon_{1 j}^{p}$; tensor das deformações plásticas

$\underline{\varepsilon}^{p}$; vetor de deformaçăo plástica

$\varepsilon_{1 j}=\frac{d}{d t} \varepsilon_{1 j}$; taxa de deformação

${ }^{E} \varepsilon_{1 j}$; tensor de deformação de ALMANSI-EULER

${ }^{L} \varepsilon_{1}$; ; tensor de deformação de GREEN-LAGRANGE

$\gamma_{\text {s }}$; energia específica.de formação de superficie livre

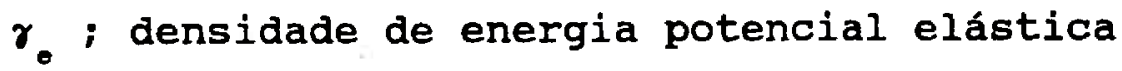

$\gamma_{p}$; densidade de energia potencial plástica

$\Gamma_{11}$ : tensor métrico de transformação

$\lambda, \mathrm{d} \lambda$; parâmetros de proporcionalidades na plasticidade

$\mu$; coeficiente de atrito de COULOMB

$v$; razão de POISSON

$\rho$; densidade do material

$\bar{\sigma}_{\text {。 }}$ tensão limite de escoamento

$\sigma_{\mathrm{m}}$; tensão média

$\sigma_{0}$; tensão de referência para a expressão de LUDWICK

$\sigma_{1,} ;$ tensor de tensões

$\sigma, \bar{\sigma}$; tensões efetivas

$\sigma_{11}$; tensor de tensão de CAUCHY

$\Sigma, \mathrm{s}$; superficie envolvendo um volume $\mathrm{V}$

$\tau$; tensão de cisalhamento

$\varphi$; função de proporcionalidade entre o tensor das deformações incrementais e o tensor das tensões reduzidadas na formulação de HENCKY-ILYUSHIN-NADAI

$\varnothing$; termo de descontinuidade material

$\omega_{j}, v_{j}$; vetor normal unitário 


\section{INTRODUÇXo}

Dentre os processos de conformação dos metais envolvendo as transformações mecânicas, o da conformação plástica dos metais é um processo mecânico bastante desenvolvido industrialmente para a produção de peças e componentes para sistemas mecánicos, ALTAN ${ }^{1}$. Esse processo é classificado como sendo de não remoção de material, e, ainda, godendo ser realizado tanto a frio como a quente. Além do mais, a conformação plástica envolve conhecimentos das áreas da mecânica dos meios contínuos dentro do campo da elasticidade e da plasticidade dos metais, as ciências térmicas, a mecânica dos fluidos, a metalurgia e a tribologia na conformação plástica, juntamente com as áreas da matemática aplicada com seus métodos analiticos e numéricos.

\subsection{Teoria da plasticidade dos metais}

o desenvolvimento da conformação plástica tem englobado os progressos alcançados nas áreas citadas, mas a teoria da plasticidade é a que mais tem contribuido com importantes avanços para o presente estado da tecnologia.

o trabalho de HILI ${ }^{2}$, até 0 ano de 1950, consolida a maioria das contribuições, tanto as experimentais como as teóricas, desenvolvidas e aplicadas na plasticidade dos metais, principalmente nas suas formulações matemáticas.

Mas a preocupação teórica com a plasticidade iniciou-se com COULOMB ${ }^{3}$, que propôs um critério para o limite de escoamento plástico dos sólidos, posteriormente aplicado na mecânica dos solos por PONCELET ${ }^{4}$ e RANKINE ${ }^{5}$. O início dos estudos sistemáticos da teoria da plasticidade dos metais se deveu a 
TRESCA ${ }^{2,5-6}$, que, desenvolvendo a ldéia de COULOMB, estabeleceu que o metal iniclava a deformação plástica quando a tensâo máxima de cisalhamento atingisse um valor critico, sendo este uma propriedade mecánica do metal obtida experimentalmente por ensaios padronizados. O trabailho de TRESCA. se baseou em resultados experimentais a partir de ensaios de puncionamento e de extrusão.

Uma primeira contribuição à teoria matemática da plasticidade foi proporcionada por SAINT-VENANT ${ }^{8}$, que aplicando o critério do início do escoamento plástico de TRESCA, determinou as tensões num tubo parcialmente plastificado, submetido a esforços de torção e de flexão. Também, SAINT-VENANT déterminou as tensões em um tubo totalmente plastificado sujeito a uma pressão interna onde se estabeleceu um sistema de cinco equações, relacionando tensões e deformações para um estado plano de deformações. LEVY 9 , seguindo as idéias de TRESCA, propôs as relações tridimensionais para as tensōes e deformações plásticas. originou-se, portanto o conhecido critério de escoamento plástico de TRESCA - SAINT-VENANT, da máxima tensão de cisalhamento.

Quase quatro décadas após LEVY, HAAR e VON KÁRMÁN ${ }^{10}$ desenvolveram as equaçōes da plasticidade a partir do principio variacional e tendo como objetivo derivá-las com base no principio generalizado de CASTIGLIANO, o qual estabelece que as tensões reais minimizam a energia elástica de um corpo isotrópico, usando uma combinação com o critério de TRESCA.

A grande contribuição, que satisfez a maioria dos metais com relação ao comportamento plástico, foi a proposta por VON MISES ${ }^{11}$, que baseandुo-se en argumentos puramente' matemáticos, estabeleceu que o material metálico iniciava o escoamento plástico quando uma certa soma de desvios 
das tensões normais e das tensões de cisalhamento quadráticas atingissem um valor crítico. Este critério de vON MISES foi posteriormente interpretado por $\mathrm{HENCKY}^{12}$ como sendo o da máxima energia da distorção, ou seja, o escoamento plástico de um metal ocorre quando a densidade de energia de deformação cisalhante elástica atinge um valor crítico relacionado com a propriedade mecânica do material. Essa propriedade é obtida através de ensaios de tração, torção ou de compressão simples. A esse critério de escoamento plástico se denominou de critério de HUBER-HENCKY-VON MISES da máxima energia de distorção. ○ mesmo proposto por HUBER ${ }^{7}$.

PRANDTL $^{13}$ mostrou que $\circ$ problema da plasticidade dos metais, no estado plano de deformação era matematicamente de natureza hiperbólica, o que permitiu o cálculo de cargas no caso da deformação plástica por compressão de superficies planas por matrizes também planas. A generalização do método de PRANDTL foi realizada por $\mathrm{HENCKY}^{12}$, que estabeleceu as propriedades geométricas do campo das linhas de deslizamento no estado plano de deformação. As equaçōes, que governam as variações de velocidade de escoamento ao longo das linhas, foram obtidas por GEIRINGER ${ }^{15}$.

o método das linhas de deslizamento é o conhecido método das características, muito utilizado na busca de soluções analíticas de problemas formulados em sistemas diferenciais parciais do tipo hiperbólicos ${ }^{19}$. As condições de existência das linhas de deslizamento são discutidas em $\mathrm{HILL}^{2}$ e KACHANOV ${ }^{20}$, onde o método é aplicado em vários problemas de plasticidade metálica na condição de deformação plana. As aplicaçōes da teoria da plasticidade nos processos tecnológicos começăram com voN KÁRMÁN ${ }^{16}$, que analisou o problema da determinação do estado de 
tensão na laminação de tiras metálicas. SACHS $^{17}$ e $\operatorname{SIEBEL}^{18}$ desenvolveram aplicações para a análise de problemas da trefilação de fios.

- estabelecimento das relações entre tensões e deformações também tem sido uma área de intensa pesquisa. Do lado experimental, uma relação simples foi a proposta por LUDWICK $^{21}$ para os metais sob condição de deformação plástica a frio. Essa relação de LUDWICK considera o encruamento como um fator importante na caracterização do escoamento plástico. A complexidade dessa relação, para a época, não permitiu a sua utilização de modo sistemático; A maioria das análises foram desenvolvidas para modelos simplificados de comportamento idealmente plástico.

Os esforços de pesquisas realizadas durante a década de quarenta, levou ao estabelecimento de outras relações experimentais que permitiram a construção de curvas de relações tensões versus deformaçōes por métodos gráficos. A relação de HOLLOMON ${ }^{22}$, seguindo a fornecida por LUDWICK, gerou a relação parabólica ou da potência, de fácil manipulação gráfica e algébrica. Mas apenas alguns metais com baixosvalores em seus expoentes de encruamento e com elevada ductilidade ọbedecem essa relação de HOLLOMON. As restrições às relações de HOLLOMON e LUDWICK levaram à proposição dé outras que serão discutidas ao longo deste trabalho, e que são as relações de: $\operatorname{vocE}^{23}$, $\operatorname{sWIFT}^{24}$ e de RAMBERG-OSGOOD ${ }^{25}$.

Para um metal de elevada ductilidade, a relação de vOCE tem sido ótima na obtenção de ajustes a dados experimentais numa grande faixa de significância estatistica, mas apresenta uma alta dificuldade na sua manipulação algébrica, principalmente quando 
inserida nas expressōes da teoria da plasticidade.

Alguns metais dúcteis, como as ligas de alumínio, obedecem melhor a relação proposta por SWIFT.

Recentemente, KIEEMOLA ${ }^{26}$ verificou numericamente as relaçōes propostas por VOCE e HOLLOMON, mas não foi possivel extrair conclusões com alto nivel de significância desses cálculos devido à natureza não-linear da deformação plástica.

Uma outra relação utilizada, principalmente em análises elasto-plásticas é à "de RAMBERG-OSGOOD, também de natureza experimental. Mas apesar de sua grande complexidade algébrica, tem sido utilizada com sucessó nas aplicaçōes estruturais em aeronáutica. A relação de RAMBERG-OSGOOD é uma fórmula que considera o ajuste aos dados experimentais, segundo uma forma normalizada.

Uma relação prática é a devida a $\operatorname{PRAGER}^{27}$, que tenta ajustar dados experimentais dentro de uma faixa infinita de deformações e conhecida como lei da tangente hiperbólica.

As relações de VOCE, SWIFT, RAMBERG-OSGOOD e de LUDWICK são conhecidas como fórmula dos três parâmetros e a, de Hollomon, como a fórmula dos dōis parâmetros. Aṣ relações citadas não são constitutivas e, portanto, não são obtidas de leis de comportamento plástico dos metais่. Assim sendo, quaisquer relações matemáticas poderão ser propostas como de ajustes, desde que satisfaçam um critério estatístico de minimizaçao de desvios quadráticos dos erros e permaneçam concordantes com os resultados experimentais. Se for possivel concentrar-se nas "dificuldades algébricas, as relações tornam-se extremamente complexas quando inseridas nos modelos relacionais de tensão versus deformação do fenômeno físico. 
Uma entre as várias complexidades é a caracterização do efeito Bauschinger, observado primeiramente por BAUSCHINGER ${ }^{28}$. Nesse efeito, o inicio do escoamento plástico de um metal, em um processo de carregamento reverso, ocorre antes que no processo sob carregamento original e direto. o efeito Bauschinger é também conhecido por ZYCZKOWSKI ${ }^{29}$ como efeito ideal. o ponto de reversão $e$ e, por sua vez, depenendente do valor da tensão limite de escoamento, que por sua vez, depende da definição convencional de deformação piástica permanente para a maioria de metais e ligas, principalmente para os dúcteis de interesse para a conformação plástica.

Não é possivel a realização de uma fórmula matemática do tipo "fechada" para o efeito Bauschinger, mas iseguindo as discussões pioneiras desenvolvidas por MASING ${ }^{30}$, o fenômeno pode ser explicado dentro de um modelo fisico-teórico, tal que a micro-heterogeneidade, seja ligada à orientação anisotrópica de cristais policristalinos. A discussão de Masing explica apenas o efeito ideal. $A B E L^{31}$, após realizaçọes de estudos teóricos $e$ experimentais seus e de outros, descreve o efeito Bauschinger por meio de variáveis, como: déformação plástica, : energia de deformação plástica e o parâmetro nominado de $\beta$-Bauschinger.

A possivel inclusão do fator que representa o efeito Bauschinger nas formulacões da teoria da plasticidade, tornariam os problemas extremamente complexos.

outras dificuldades, existentes na : teoria da plasticidade, são as relacionadas com a construção de expressões tensão versus deformação, válidas para a deformação ou escoamento plástico per si.

Duas grandes divisōes surgiram para o trato desses 
problemas: a teoria do escoamento plástico e a teoria da deformação plástica.

Na teoria do escoamento plástico, dois métodos têm sido amplamente utilizados até o presente. $0^{\circ}$ primeiro que abordaremos é - da teoria incremental da plasticidade devido a LEVY ${ }^{32}$ e VON MISES $^{33}$, e o segundo é a teoria incremental da plasticidade desenvolvida por PRANDTL ${ }^{34}$ e REUSS $^{35}$, incluindo a deformação incremental elástica.

os complexos estados de tensão e deformação existentes num sólido metálico elástico sob condição de plastificação, exigiu - desenvolvimento de métodos de análises também com grandes complexidades. A primeira questão foi a da grandeza da deformação plástica, que provocou o surgimento de aproximações de deformações dentro de um modelo de escoamento atribuido a LEVY e VON MISES, análogo ao desenvolvimeñto matemático do escoamento de um fluido altamente viscoso. Esse modelo de escoamento plástico seguiu uma base incremental, de modo que 'o mesmo é também denominado de teoria incremental do escoamento plástico. Na teoria de LEVY-VON MISES, as deformações elásticas são despreziveis ao serem comparadas às deformações plásticas, sendo o modelo denominado de rigido-elástico plástico. Nessa teoria, de LEVY-VON MISES, - tensor das tensões reduzidas é proporcional ao tensor das taxas de deformações no regime plástico. Existem também identidades de direções e similaridades entre as tensões reduzidas e as taxas de deformações. Os parâmetros de $\operatorname{LODE}^{38}$ das deformações e os das tensões são rigorosamente iguais. Essas propriedades levam à ocorrência de normalidade na superficie de escoamento, caso se admita a existência de um potencial plástico associado.

A constante de proporcionalidade, existente entre os 
tensores das tensões reduzidas e os daś deformações incrementais, é um parâmetro a ser determinado $e$ seu valor é geralmente obtido pela imposição de um critério de escoamento plástico, podendo ser o de TRESCA-SAINT-VENANT como proposto originalmente por LEVY ou o critério de VON MISES-HENCKY, proposto por VON MISES. .

$\mathrm{Na}$ construção operacional do modelo de escoamento plástico de LEVY-VON MISES, é necessário considerar os"invariantes dos tensores de tensões e de deformações incrementais, como já discutidos em HILL ${ }^{2}$, SLATER ${ }^{6}$, JOHNSON e MELLOR ${ }^{7}$.. KACHANOV ${ }^{20}$, ZYCZKOWSKI ${ }^{29}$, DIETER ${ }^{36}$ e NADAI $^{37}$, onde são definidos os primeiros, segundos e tërceiros invariantes tensoriais das tensões e das deformaçōes incrementais. Os primeiros invariantes são, respectivamente, relacionados cóm a pressão hidrostática e com a nulidade incremental volumétrica devido às, deformações incrementais normais. Os segundos invariantes são os quadráticos das intensidades ou dos equivalentes de tensões e de deformações. Já os terceiros não recebem definições físicas! mas estão relacionados com as determinações angulares dos tipos de estados de tensões e de deformações; esses ângulos são caracterizados pelo parâmetro de Lode, que depende em última instância dos segundos e terceiros invariantes.

- conceito ${ }^{\circ}$ de potencial plástico proposto por voN MISES $^{39}$ em 1928, procura definir os componentes de um tensor de deformação de segunda ordem, em 'função de uma função escalar do tensor de tensões, a partir desta, é sempre possivèl estabelecer as equaçōes de escoamento plástico de LEVY-VON MISES.

A teoria do escoamento plástico de PRANDTL-REUSS é a generalização dessa teoria de LEVY-VON MISES, onde agora se 
considera na formulação, os incrementos das deformações elásticas.

A teoria da deformação plástica, devido a HENCKY ${ }^{12}$ [1924] é um modelo não linear de deformação elástica e a mesma despreza as irreversibilidades e dependências de trajetórias, tão importantes nos modelos incrementais. A mesma é válida para pequenas deformações elasto-plásticas. Essa teoria estabelece a proporcionalidade entre os tensores das tensões reduzidas e das deformações incrementais.

A formulação "proposta por HENCKY ${ }^{12}$ para a teoria da plasticidade e aplicada por $\operatorname{NADAI}^{40}$ [1923] no problema especifico de torção de uma barra, recebeu uma grande contribuição com os trabalhos de ILYUSHIN ${ }^{41-44}[1943-1947]$, que a transformou de um modelo de deformação plástica infinitesimal, para um de elasticidade não-linear, onde o estado de deformação final, num processo de plastificação, é independente da trajetória seguida após um estado inicial de partida elástico, por um processo de deformação plástica.

No processo de deformação plástica, uma outra equação deve ser introduzida nas equações de mudança de forma, cujo objetivo é o da equalização entre os. números de equações e de variáveis. De acordo com ZYCZKowSKI ${ }^{29}$, na teoria das deformaçōes elasto-plástica de HENCKY-YLYUSHIN-NADAI, essa variável é o coeficiente de proporcionalidade existente entre o tensor das tensões reduzidas e o tensor das deformações, sendo ela denominada de função de desenvolvimento das deformações plásticas. São também postulados, nesse modelo de deformação plástica, a identidade dos tensores das direções e a similaridade entre as tensões $e$ as deformações, bem como a igualdade dos parâmetros de LODE.

A condição de incompressibilidade leva à: condição de 
constáncia de volume, válida até para altos valores de pressão hidrostática, mostrada experimentalmente por BRIDGMAN ${ }^{45}$ [1923], quando foi estabelecido que a mudança de volume ocorria de modo linear e puramente elástica, desviando-se dessas condições, apenas quando ocorria a não-linearidade entre a pressão hisdrostática e a variação de volume ocasionada pela contribuição das grandes deformações plásticas.

A teoria da deformação plástica de HENCKY-ILYUSHIN-NADAI é bastante restrita, segundo ZYCZKowsKI $^{29}$, mas éaplicável onde outras teorias mais exatas apresentam, muitas complicações teóricas.

É de comprovação experimental, como é discutido em KACHANOV ${ }^{20}$, que cerca de $95 \%$ do trabalho de deformação plástica é dissipado na forma de energia térmica, levando, portanto, a uma irreversibilidade no processo e contrariando, então, o postulado do modelo de HENCKY. A irreversibilidade leva à condição da dependência da trajetóría de deformação plástica entre os estados inicial e final do processo. Nessa teoria, não se considera o alto grau de anisotropia no processo, fato que foi estudado por HILL $^{2,45}$, que propôs uma função de escoamento plástico, formulada de modo que a mesma fôsse uma superficie de escoamento plástico quadrática análoga à de VON MISES-HENCKY. Finalmente, ñ̃o é incorporado nessa teoria o efeito BAUSCHINGER.

Dentro da mecânica dos meios contínuos, certas expressões existentes foram reformuladas e outras construidas, para permitir uma análise mais completa dos processos de deformação plástica. o critério físico da energia de distorção, devido a VON MISES $\widehat{S}^{11}$ deu origem. à respectiva formulação matemática do mesmo critério, por $\mathrm{HENCKY}^{12}$, onde se postulou que 
os escoamento plástico se iniciava quando a energia de distorção elástica era igual ou maior que um valór critico pré-estabelecido e possivel de ser obtido experimentalmente, através de ensaios padronizados. Na atualidade, não é satisfatória a aplicação desse critério de escoamento nos materiais metálicos disponíveis, mas a reformulação do critério foi sugerida por VoN MISES ${ }^{39}$ [1928], que propôs uma relação constitutiva fundamental, baseada no princípio da normalidade, onde o incremento de deformação plástica é definido em relação à superficie de escoamento. GOL'DENBLAT ${ }^{46}$ [1962] demonstrou, por teorema do potencial termodinâmico, que existia um potencial plástico, em função do segundo invariante do tensor das tensões reduzidas. Se ocorrer de a superficie de escoamento ser idêntica ao potencial plástico, então a plasticidade é associada.

Essa conclusão, devidó aos trabalhos de VON MISES ${ }^{39}$, GOL'DENBLAT ${ }^{46}$, ZYCZKOWSKI ${ }^{29}$ é importante para a teoria da plasticidade e é também a base para a construção dé um possível modelo variacional elasto-plástico para a busca de soluções de problemas de comformação plástica, pelos métodos dos elementos finitos zIENKIEWICZ ${ }^{46}$ [1977] ou pelo método do limite superior HILL $^{2}$ [1950], PRAGER e HODGE ${ }^{48}$ [1951] e AVITZUR ${ }^{49}$ [1968].

A superficie de escoamento plástico deve satisfazer o postulado da elasticidade de $\operatorname{DRUCKER}^{50,51}[1956,1959]$, onde, para um processo de deformáąão isotérmico, o excesso" de trabalho plástico, devido a um incremento de deformação tensorial, num estado tensorial de tensão, produzido por um incremento tensorial de tensão, causado por um agente externo, é não-negativo.

A condição de DRUCKER garante a convexidade da superficie de neutralidade, onde temos a separação entre regiões 
elástica e plástica. A sua possivel violação por amolecimento plástico ou pela presença de tríncas, permite a construção de um critério de conformabilidade.

A validade do postulado de DRUCKER tem sido garantida pelo argumento heuristico de $\operatorname{KOITER}^{52}$ [1953], onde é afirmado que, mesmo no caso da presença de cantos na superficie de escoamento, a continuidade do material metálico, que exige a compatibilidade entre as deformações, necessita de uma combinação linear dos campos de deformações posicionados em lados opostos do canto, a fim de se evitar valores contraditorios ou casos de descarregamentos. Os a coeficientes dessas combinações lineraes dfeverão ser não-negativos.

$\mathrm{Na}$ teoria geral da "plasticidade, é de" fundamental importância a verificação das possiveis definições de deformaçōes no rehgime plástico. Tais definições, matemáticas por natureza, devem ser adequadas para o tratamento das expressões de tensões versus deformações existentes nos corpos sólidos.

As seis possiveis deformaçōes presentes num problema tridimensional não são porém arbitrárias, mas devem satisfazer as condiçōes de compatibilidade entre si de modo a ser possivel suas definições em termos de três funçōes de deslocamẹto.

A mais comum das definições de deformações encontrada no campo da plasticidade é a de $\operatorname{HENCKY}^{53}$ [1928], introduzida por LUDWICK $^{21}$ [1909], a qual NADAI ${ }^{54}$ [1937] denominou de deformação natural.

outras definições de deformações são a de LAGRANGE ou deformação material e a de EULER ou deformação geométrica. zYCZKOWSKI ${ }^{29}$, estabelece as expressões existentes entre as três definições de deformações e que é de fundamental 
importancia para a interpretação e análise de resultados analiticos, numéricos e experimentais.

As deformações apresentam em suas formulações as arbitrariedades geométricas de suas definições mas são idênticas para pequenos valores. No entanto, na plasticidade dos metais podemos esperar grandes valores nas deformações e qualquer método de cálculo tem que ser especificado para qual modelo de deformação o mesmo é válido.

A maioria dos resultados possíveis de serem obtidos através de métodos fundamentados na mecânica dos meios continuos foram apresentados até este' ponto; mas, analisando-se as modificaçōes que provocaram reformulaçōes na teoria da plasticidade, observa-se que determinadas condições são consideradas matematicamente "fortes" e serão discutidas a seguir.

A primeira violação do contínuo ocorreu com o próprio significado físico da plasticidade e a sua superação ocorreu na década de trinta com a introdução do conceito de disçordância que por sua vez permitiu a compreensão e a modelagem do comportamento plástico dos metais. Fenômenos, tais como: encruamento, efeito BAUSCHINGER, limite de escoamento, anisotropia e outros passaram a ser estudados, segundo esse micromecanismo de deformação plástica, em HIRTH e LOTHE ${ }^{55}[1968]$. A teoria das discordâncias foi, na época de sua introdução, um conceito fundamentado na observação experimental de $\mathrm{MUGGE}^{56}$, onde a deformação plástica era procedida da formação de bandas de deslizamentos, mas baseada num modelo de elasticidade para um meio homogêneo e isotrópico. e que cuja configuraçāo geométrica era a de um cilindro. secciona do longitudinamente. LOVE $^{57}$ [1927] propos um método de avaliaçāo do campo de tensões em torno dessas discordâncias. 
Os fundamentos da teoria moderna das discordâncias foram estabelecidos simultanea $e$ independentemente, de acordo com NABARRO $^{58}$ [1967], por TAYLOR ${ }^{59}$ OROWAN $^{60}$ e POLANYI ${ }^{62}$ em 1934, para explicar a discrepancia que existia entre os valores das tensões de cisalhamento teórica e experimentais de materiais metálicos. Os valores teóricos das tensões de cisalhamento foram: obtidos por meio de um modelo proposto por FRENKEL ${ }^{62}$ [1926]. O valor obtido pelo modelo de FRENKEL era muito elevado, e MACKENZIE ${ }^{63}$ [1949] prop s um outro mais reduzido, após uma análise por forças centrais para um caso de rede cristalina do tipo pacote fechado. os dois resultados são consolidados na inequação:

$$
3 \times 10^{-2} \mathrm{G}<\tau_{\text {teorlco }}<2 \times 10^{-1} \mathrm{G}
$$

válida para a temperatura ambiente. $G$ é o módulo de cisalhamento do material.

o modelo de MACKENZIE foi uma sub-avaliação da tensão de cisalhamento máxima teórica, possivel de ser obtida somente próxima do ponto de fusão de metais cristalinos.

A discrepância entre os modelos de discordâncias de FRENKEI e MACKENZIE pode ser expliicada pela postulação da presença de defeitos de linhas, que foram denominadas de "discordancias".

BRENNER $^{64}$ [1958] verificou que para.monocristais metálicos filamentares, com baixa densidadede discordâncias, os "whiskers", os valores das tensões de cisalhamento máximo eram da ordem de:

$$
\tau_{\text {teorico }} \simeq 6 \times 10^{-2} \mathrm{G}
$$

Já os trabalhos experimentais de TINDER $^{65}$. com cobre e 
zinco, indicaram que a deformação plástica iniciava-se para tensões de cisalhamento da ordem de:

$$
\tau_{\text {teorlco }} \propto 10^{-9} \mathrm{G}
$$

valores estes, extremamente inferiores aos obtidos para os "whiskers". A conclusão foi de que os metais apresentaram altas densidades de defeitos lineares em suas formas cristalinas.

Nas suas formas mais simples,' consolidou-se os conceitos de discordancias de TAYLOR ${ }^{59}$ [7934] $e$ as de BURGERS ${ }^{65}$ [1939], denominadas de cunha e em hélice respectivamente. Outras formas existem, tais como as de VOLTERRA ${ }^{67}$ e as SOMIGLIANA $^{68}$, que são os os campos de discordâncias para os análogos continuos das discordâncias de TAYIOR e BURGERS, mas envolvendo,' neste casos, malhas cristalinas maiores.

\subsection{Mecânica da Fratura Linear e Não-linear}

A revisão dos trabalhos, relacionados com o estudo da mecânica da fratura, seguirá um ponto de vista diferente dos normalmente encontrados na literatura técnica. A principal razão é a de proporcionar uma melhor visụalização da importância do estudo das discordâncias e o conseqüente desenvolvimento das integrais invariantes na análise de trincas e outros defeitos nos materiais metálicos. Os experimentos controlados, desenvolvidos por GRIFFITH em 1920, deram origem à teoria clássica da Mecânica da fratura linear elástica. As discrepancias encontradas nos resultados dos experimentos onde a tensão de tração para a ruptura de um corpo de prova de vidro era da ordem de

$$
\tau_{\text {aplicada }}=\mathrm{E} / 400
$$

enquanto que a resistência teórica de um sólido deveria ser da ordem de 


$$
\tau_{\text {teorlco }}=\mathrm{E} / 6
$$

onde $\mathrm{E}$ é o modulo de elasticidade.

A essa discrepancia, GRIFFITH postulou a existência de microtrincas.

o critério de "fratura de GRIFFTH é a aplicação direta da segunda lei da termodinâmica, isto é: se uma trinca está se propagando, então a energia libérada, que é a diferença entre a variação do trabalho das cargas externas e a variação da energia de deformação do corpo, durante um aumento da extensão da trinca, deve ser equivalente à energia de superfície necessária para criar pequenos incrementos de trincas superficiais. $\dot{E}$ esse o conceito clássico da mecânica da fratura linear, fundamentado totalmente na teoria da elasticidade dos sólidos.

A mecânica da fratura não-linear elasto-plástica tem como seu modo operador a presença de um campo de tensōes geradó por acumulo de discordâncias. Essas por sua vez dão origem aos campos contínuos de discordâncias denominadas de discordâncias de VOLTERRA e de discordânclias SOMIGLIANA, associadas às singularidades nos meios continuos oriundas de defeitos $e$ falhas internas nos sólidos.

ESHELBY $^{66}$ [1956], introduziu o conceito de força em tornode singularidades num material elástico, como sendo o gradiente negativo da energia total do corpo, em função da mudança de posição de um defeito no sólido. segundo ESHELBY, tais singularidades elásticas poderiam ser discordâncias, inclusões, vacâncias e/ou outros defeitos. o estímulo para essas análises, foi o interesse das amperfeçôes numa rede metálica cristalina dentro da teoria física do estado sólido e o surgimento da 
modelagem de imperfeições, pela teoria clássica da elasticidade. Também ESHELBY mostrou que a força elástica é dada por uma integral de uma superficie, envolvendo um volume contendo o defeito e, ainda, por uma modelagem num meio contínuo.

É de se notar que o desenvolvimento da teoria da plasticidade levou ao surgimento da teoria das discordâncias, como sendo o seu micromecanismo operante a nivel cristalino. Da teoria das discordâncias básicas de TAYLOR e BURGERS e, por proposta de ESHELBY, surgiram para o análogo contínuo, as discordâncias de VOLTERRA e SOMGLIANA ${ }^{69}$. Estas, por sua vez, permitiram a análise de defeitos em meios elasticamente continuos, por meio da construção de uma integral variante de superfície.

Do exposto até este ponto, ao melhor resultado a que se chegou foi com ESHELBY em 1956, adicionando-se ainda a conclusão de que, se o volume contido no interior de uma superfície não possuir nenhum defeito, a integral invariante de sup̣erficie deve ser nula.

A passagem, da análise de uma rede cristalina, contendo defeitos de Iinhas de TAYLOR e BURGERS, para a correspondente análise de um problema análogo elástico deve ser associada a cada tipo de defeito, num estado de tensão interna, defeito este conhecido como singularidade.

As principais singularidades de interesse físico, de acordo com ESHELBY, são casos particulares do modelo de distribuição contínua de discordâncias do tipo. SOMIGLIANA ${ }^{68}$. Ainda, as discordâncias de VOLTERRA ${ }^{67,70}$ são casos particulares do modelo SOMIGLIANA.

As discordâncias de VOLTERRA representam as fronteiras de grâos torcidos e com pequenos ângulos; já as.discordâncias 
SOMIGLIANA representa o modelo contínuo de empilhamento de discordancias em torno de obstáculos, criando, portanto, um campo de discordâncias continuas.

- campos de tensões internas gerado pelas. discordâncias SOMIGLIANa, devido adefeitos ou falhas no interior de um sólido elástico, não é do mesmo tipo do das tensões residuais geradas por solicitações externas. A analogia de ESHELBY, para a determinação de forças em materiais contendo defeitos internos, é oṛiginária da teoria eletrostática, onde se estabelece o campo elétrico num meio infinito, devido à presença de cargas elétricas no seu interior.

A força do campo elétrico é de curto alcance, assim como - são as forças originadas pelas singularidades materiais.

As singulariàădes materiais poderão ser: discordâncias, inclusões e vancâncias, para citar algumas. ELSHELBY mostrou que as forças internas poderiam ser dadas por uma integral de superficie, envolvendo os defeitos. Na ausência de defeitos internos, essa integral se reduz a zero e pode-se obter, portanto, uma lei conservativa. Essa lei conservativa, de fato existe, e é geral, tendo a aplicabilidade numa classe muito grande de problemas. Tem esse lei origem e base num teorema variacional, devido a NOETHER ${ }^{71-72}$ [1918]. O acúmulo de defeitos: em torno das singularidades dão origem à nucleação de microtrincas, segundo micromecanismos de fratura a serem discutidos a posteriori. A mecânica da fratura oriğinou-se de outro ponto de vịsta, ou seja, dos estudos de estados de tensão e deformação em torno de singularidades.

Pesquisas de fratura mecânica nos estados de deformação e tensão planas levaram, independentemente, $\operatorname{RICE}^{73}$ [1968] e 
CHEREPANOV $^{74}$ [1967] a representarem a força de extensão de uma trinca ou a denominada taxa de liberação de energia de GRIFFITH-IRWIN ${ }^{75}$ como sendo uma integral de caminho de integração, que passou a ser chamada de Integral-J de RICE. BEGLEY e LANDES ${ }^{76}$ [1972] provou ser essa integral, de grande utilidade prática para a análise de fraturas nos sólidos.

As análises de $\operatorname{RICE}^{73}$ e CHEREPANOV ${ }^{74}$ foram desenvolvidas para campos e elastostáticosplanos, sob formulação de deformação infinitesimal, mas com a possibilidade da existência de expressões de tensão versus deformação de natureza não-linear elástica. Nessa condições, é possivel aplicar a,integral-J de RICE na análise de trincas nos sólidos sob estado plano de plastificação, desde que obedeça as relaçãoes da teoria da deformação plástica de HENCKY ${ }^{12}$. A natureza do trabalho de RICE é de primordial importância nas análises diretas das concentrações de tensões singulares, induzidas geometricamente por trincas e entalhes.

A maioria das aplicações da Integral-J é dentro do campo de comportamento inelástico dos materiais metálicos, e é onde HUTCHINSON $^{77-78}$ [1968] e também RICE e ROSENGREN ${ }^{79}$ [1968], usando a teoria da deformação plástica de HENCKY, num campo tensão e deformação plana, estabeleceram a distribuição de tensões em torno de uma trinca, usando a integral-J de RICE, fator amplificador de campo. Esse modelo foi denominado HRR, em homenagem a HUTCHINSON, RICE e ROSENGREN, e é a base para a análise da fratura mecânica na engenharia em campo elasto-plástico.

KNOWLES e STERNBERG ${ }^{80}[1972]$ estebeleceram dois adicionais tipos de leis conservativas, denominados de integral-L e integral-M, e que juntamente com a integral-J de RICE formam as integrais invariantes básicas para os casos de deformação e tensão 
planas.

Às integrais-J, $L$ e $M$ foram dadas interpretaçōes fisicas por BUDIANSKY e $\operatorname{RICE}^{81}$ [1973] pela generalização das integrais invariantes para os casos tridimensionais. A natureza invariante dessas integrais foi mostrada por KNOWLES e STERNBERG, seguindo as bases do teorema de NOETHER.

$\operatorname{RICE}^{79}$ e AOKI et alii... ${ }^{82}$ [1984] mostraram que essas integrais generalizadâs podem ser interpretadas, como sendo taxas de liberação de energia para fora da região de formação das trincas.

No caso de a cavidade ou ponta da trinca ser transladada de sua posiçāo relativa para o interior do corpo material ter-se-á a integral-J $\mathbb{K}$. No caso de ocorrer uma rotação dạ cavidade ou trinca, ocorrerá a integral- $L_{k} e$, finalmente, na ocorrência de expansão auto-similar translacional, produzir-se-á a integral-M.

FUNG $^{83}$ [1965] mostra que a plasticidade dos metais, dentro da mecânica dos meios continuos, em suas expressões tensoriais, deve satisfazer os teoremas das condições de equilibrio de forças do balanço de energia e da continuidade material, e tudo isso deve estar acoplado por expressões constitutivas de natureza, hoje absolutamente experimentais.

É importante, situar o problema gerado pela introdução da teoria das discordâncias cristalinas na terceira década deste século de 1900 .

A ligação da teoria das discordâncias com a plasticidade dos metais, foi realizada com a introdução do conceito de discordâncias continuas ou infinitesimais, com a: adoção das discordâncias somIGLIANA. Agora, a passagem para o conceito de taxa de liberação de energia da região de trincas por abordagem 
termodinâmica e da dinâmica ou pelas integrais invariantes, baseadas no teorema de NOETHER, permite a análise de defeitos, trincas e falhas internas no campo da. teoria da elasto-plasticidade, no que se denomina na atualidade, de Mecânica da Fratura Não-linear ou Mecânica da Fratura Elasto-plástica.

- estudo da mecânica da fratura tevé origem nos trabalhos experimentais de GRFFFTHS ${ }^{84}$ [1920], que analisou a propagação de trincas em materiais frágeis e é conhecida como Mecânica da Fratura Linear.

A unificação dos estudos da mecânica da fratura frágil com a da fratura dúctil se devem muito a $\operatorname{RICE}^{73}$ e foi 0 resultado do desenvolvimento, iniciado pelas análises de ESHELBY ${ }^{66}$.

A primeira preocupação com os problemas de concentraçōes de tensões em torno de trincas e cantos em meios metálicos deveu-se aos trabalnos de INGLIS $^{86}$ [1913], .: seguindo as aproximaçōes da teoria da elasticidade: PARTON e MOROZOV ${ }^{85}$ [1974] admitem que a fundação da mecâniça da fratura se deve à afirmação de GALILEO GALILEI, que a carga de quebra de um sólido é independente do comprimento de uma barra sob tração e é diretamente proporcional a sua secção mormal.

Já GRIFFITH ${ }^{84}$, após um número elevado de testes com vidros, tratou a questão da fratura frágil, através de argumentação energética, onde estabeleceu que estabilidade do corpo sólido elástico, deformando por forças ide contornos especificados, deve-se a um armazenamento de energia potencial mínima. Constatou também, que, para materiais contendo microtrincas, a tensão, na qual ocorria' a ruptura, era menor que a tensão de escoamento do material. GRIFFITHS ${ }^{84}$ propôs um critério 
pela adição do conceito de que a posição de equilíbrio era aquela, na qual ocorria a ruptura do material soolido. A idéia era a de que a energia potencial elástica diminuia pela liberação de energia com a respectiva formação de superficies livres.

- cálculo da concentração de tensão para análise de GRIFFITHS $^{84}$ foi baseado no modelo de INGLIS ${ }^{86}$. Uma generalização para $\circ$ caso tridimensional do modelo, foi realizado por $\mathrm{SACK}^{87}$ [1946], que modelou a trinca, como sendo uma esferóide achatada nos polos.

- modelo de fratura de INGLIS-GRIFFITH e SACK é válido apenas para materiais frágeis. o conceito de fratura frágil é o de que se na vizinhança da ponta da trinca houver uma tensão resolvida menor que a ténsão limite convencional de escoamento do material, a trinca propaga-se com uma velocidade de cerca de $38 \%$ da velocidade longitudinal do som, no meio material (MOTT ${ }^{88}, 1948$ ) desde que este mesmo material admita apenas um baixo valor de absorção de energia elástica.

Em engenharia, poucos materiais metálicos são verdeiramente frágeis e, sob esta condição, o modelo proposto por GRIFFITH é não realístico. OROWAN ${ }^{89}$ [1955] propôs uma correção para sanar essa contradição, acrescentando uma parcela de deformação plástica, responsável por uma absorção de energia maior que a permitida no modelo de GRIFFITH. Essa correção de OROWAN é a responsável pelas altás tenacidades à fratura, passiveis de se encontrar nos principais materiais metálicos.

- modelo de fratura 'de INGLIS-GRIFFITH-SACK e agora OROWAN foi complementado na mecânica da fratura com os trabalhos de WILIIAMS $^{90}$ [1957] e $\operatorname{IRWIN}^{91}$ [1957], ambos baseados no trabalho inicial de SNEDDON $^{92}$ [1946], que formularam os campos de 
distribuição de tensões na vizinhança de trincas em sólidos metálicos.

A Mecânica da Fratura Iinear Elástica, dentro de sua faixa de validade, é restrita a valores de tensões aplicadas da ordem de $37 \%$ da tensão limite de escoamento. Isto porque a propriedade material de tenacidade à fratura linear elástica $\mathrm{K}_{\mathrm{Ic}}$ é obtida por meio de um ensaio padronizado, estabelecido pela ASTM ${ }^{93}$ [1989]. Esse valor é menor que a faixa estabelecida para validade da teoria da elasticidade, onde a tensão efetiva deve estar compreendida numa faixa de até $80 \%^{\circ}$ da tensão de limite de escoamento. o tratamento de PARKER $^{93}$ [1981] para a fratura linear é restrita aos valores acima citados.

Os materiais metálicos utilizados na engenharia permitem valores de tensões mais elevados que 0 citados anteriormente para a inicialização e propagação de trincas e, ao mesmo tempo, a velocidade de propagação da mesma é bẹ menor que o valor de $38 \%$ da velocidade de propagação do som nos metais.

SHAW $^{95}$ [1984] propôs, para superar as restrições já apresentadas, que parâmetros tais como, instabilidade plástica, grandes deformações plásticas e fratura dúctil, devem ser incorporados em um melhór modelo de mecânica da fratura.

SANDERS $^{75}$ [1960] propôs uma nova formulação para o modelo de propagação de trinca' de GRIFFITH-IRWIN, baseada numa integral de linha independente do caminho de integração. Mas apenas CHEREPANOV ${ }^{74}$ [1967] e RICE $^{73}$ [1968] formalizaram a proposta de SANDERS para materiais elasto-plásticos, segundo a teoria da deformação plástica de HENCKY, que deu origem à Mecânica da Fratura Não-linear Elasto-plástica.

Para os metais de interesse à conformação plástica, a 
possivel inicialização e propagação de trincas é do tipo fratura dúctil e o modelo elasto-plástico é $\circ$ mais indicado nas aplicações.

As integrais invariantes: $J_{x}, I_{x} e M$, aplicáveis nas mecânicas da fratura linear e não-linear, são parâmetros de campo solidamente construidas, de acordo com o teorema invariante de NOETHER e segundo a a concepção da teoria 'contínua das discordâncias. Essas integrais serão consideradas nas aplicações, envolvendo regiōes elasto-plásticas, trincas e defeitos. Já no caso da mecânica da fratura linear elástica, aplicada em problemas elasto-plásticos, o fator de importância é o parâmetro $\mathrm{K}$, denominado de fator de intensidade de tensão. 0 mesmo é um parâmetro pontual, sendo também de dificil avaliação; mesmo com o auxilio de métodos numéricos computacionais.

MCMEEKING $^{96}$ [1977] estabeleceu algumas expressōes para análise do campo de deformação na vizinhança de trincas, em materiais elasto-plásticos, através do modelo de deformações finitas, válidas para regiōes plastificadas em pequena escala. BEGLEY e LANDES $^{97}$ [1972] propuseram a exìstência de uma relação entre os valores criticos de $K$ e $J$, desde que a plastificação na região de uma trinca seja de pequena escala.

A proposta de BEGLEY e LANDES tem sua i-mportância nas aplicações porque, grıando os parâmetros $\mathrm{K}$ e $\mathrm{J}$ atingem os respectivos valores criticos $K_{I C}$ e $J_{I C}$ ' serão, na realidade, valores de propriedades materiais relacionados à tenacidade à fratura. Essa proposta permite, também, uma direta extrapolação do conceito de fratura linear elástica para os casos elasto-plásticos, em uma condição de plasticidade generalizada em torno da ponta da trinca, mas, ainda assim, em pequena escala. 
Um terceiro método de tratamento dos problemas de fratura em materiais dúcteis é apresentado por $\operatorname{RITCHIE}^{98}$ [1983], no qual é afirmado que, uma grande vantagem da análise pela mecánica da fratura, é que a mesma correlaciona os aspectos macroscópicos da nucleação e crescimento de trincas sem recorrer a modelos microscópicos para processos de fraturas localizadas, que, por sua vez, dependem da natureza da microestrutura e das histórias da tensão e da deformação na ponta da trinca.

WILSDORF ${ }^{99}$ [1983], entretanto, mostra que para sólido cristalino, a fratura dúctil é precedida pela deformação plástica, dando como resultado um número grande de problemas complexos. Confirma ainda que, enquanto a análise macroscópica pode ser realizada a partir das condições de um experimento (tais como: dados de tensão-deformação, geometria do corpo de prova e observações óticas) párá o estudo da enucleação e propagação de trincas necessita-se de informações dos processos; que ocorrem dentro do sólido, mas numa escála que exceda a resoluçâo de um microscópio ótico. Se certas hipóteses forem postuladas, então, a mecânica da fratura trata o sólido de acordo com a concepção de um meio contínuo. Esse tipo de modelagem da fratura macroscópica recebeu contribuição decisiva de $\operatorname{MCCLINTOCK}^{100}$. [1968], que construiu um modelo contínuo de fratura, segundo um critério de crescimento e coalescência de cavidades dentro do sólido. KNOTT ${ }^{101}$ [1980], por sua vez, modelou o mecanismo de fratura através de micromecanismo de nucleação, crescimento e propagação de trincas, pela interferência dẽ "particulas de segunda fase : presentes no sólido.

IRWIN $^{102}$ [1985] mostra que as fraturas, que ocorrem em um material sólido, são do tipo progressivas pelo espalhamento da 
trinca no material

Um quarto tipo de abórdagem dos problemas de fratura está relacionado com métodos numéricos, principalmente, o dos Elementos Finitos. KEIM e MÜLLER ${ }^{103}$ [1989] discutem a respectiva modelagem para a aplicação do método. Apesar de afirmarem que o mesmo é o adequado para a análise quantitativa dos problemas de mecânica da fratura não-linear, sabe-se que, ainda, existem dificuldades na própria modelagem física das fraturas.

BROBERG $^{104}$ [1971] confirmou que existia uma região do processo de fratura perto da ponta da trinca, tal que ocorria a coalescência de micratrincas. de modo que não era possivel a aplicação de teoremas da mecânica dos meios contínuos.

Apesar da mecânica dos meios continuosnão funcionar nas regiões de ocorrência de processos microestruturais, AOKI $^{105}$ et alii [1981] confirmou que no balanço do sistema em termos de energia, este tem que ser satisfeito pela imposição de uma taxa de liberação de energia devido a propagação de trincas. os mesmos pesquisadores, neste trabalho, propuseram a existência de novas integrais invariantes $L, M$ e $I$, associadas com processos de fraturas rotacional, auto-similar e distorcional, respectivamente. Elas são definidas na presença de deformação plástica, deformações térmicas, forças centrais e forças inerciais. Incluem, como casos especiais, as integrais invariantes de $J, L$ e $M$ definidas por KNOWLES e STERNBERG ${ }^{80}$, apresentadas por BUDIANSKY e. RICE. ${ }^{81}$,como sendo a taxa de liberação de energia, devido à existência de cavitação ou trincas em materiais elástico-plásticos:

KISHIMOTO $^{106}$ [1980] e colaboradores formularam $\circ$ conceito de uma integral invariante translacional $\hat{\jmath}$ : generalizada, permitindo a existência, dentro da região de processo de fratura, 
dos efeitos da deformação plástica, forças centrais, deformações térmicas e forças inerciais. Nesse mesmo trabalho foi proposta a generalização dessa integral-J para o caso tridimensional, que é a base deste trabalho de pesquisa.

BRUST $^{107}$ [1984] generalizou ainda mais 0 conceito de integrais invariantes pela introdução da integral invariante $T^{*}$, na forma incremental válida para sólidos experimentando qualquer tipo de comportamento não linear, incluindo: plasticidade, fluência e viscoplasticidade. A restrição ao trabalho de BRUST para as aplicações é que este foi apena's validado por simulação computacional pelo método dos Elementos Finitos, mesmo tendo sido bem fundamentado no seu tratamento analitico. Essa restrição pode ser eliminada pela experimentação laboratorial da integral invariante generalizada $\mathrm{T}^{*}$.

\subsection{Conformação Plástica dos Metais}

A conformação plástica dos metais, de acordo com THOMSEN, YANG e KOBAYASHI ${ }^{108}$ [1965], é um dos mais importantes processos de fabricação mecânica e é na prática, muito empregado, de tal modo que $80 \%$ dos produtos metálicos passam por esse processo, segundō B̈RESCIANI ${ }^{109}$ et a.lii [1984].

A conformação plástica consiste no processo de alteração da forma de um sólido metálicio, pela sua deformação plástica, causada pela imposição de um sistema de solicitação de cargas externas, sendo o sólido envolvido por contornos elasticamente rígidos. Estes contornos formam a matriz de conformação. o processo de deformação ocorre sem a remoção de material do corpo sólido.

A conformação plástica pode ser realizada a frio ou a 
quente. Seu limite é imposto se a temperatura de trabalho (temperatura do sólido a ser conformado), for menor que aproximadamente $40 \%$ a $50 \%$ da temperatura de recristalização do metal base de uma liga metálica. A conformação é, então, denominada conformação a frio e a deformação a quente é o caso contrário, ém JoHNSON e MELLOR ${ }^{110}$ [1983]. A natureza dessa divisão deve-se ao processo de ativação do movimento de discordâncias, que no caso, do trabalho a frio, permanecem imobilizadas em grande porcentagem, ocasionando, como conseqüênci ${ }^{7}$, o encruamento do material. (POLUKHIN et alii ${ }^{111}$ $[1983])$.

Ao mesmo tempo que ocorre uma alteração de forma pela conformação plástica no material metálico, ocorrem mudanças em suas propriedades mecânicas, tais como: diminuição da ductilidade pela redução da reserva plástica; aumento da resistência mecânica ocasionada pelo encruamento, se o trabalho for realizado a frio; variação no acabamento superficial, que pode ser dé fundamental importância para a definição do uso final ou para posterior trabalho de usinagem.

As variaçõoes apresentadas são de tão grande importância tecnológica $e$, também, influem em tão 'alto grau nos processos de conformação, que foi necessário introduzir uma nova área de pesquisa, denominada conformabilidade plástica dos metais. A conformabilidade foi, inicialmente, baseada em experiências laboratoriais com corpos de provas de dimensões reduzidas, objetivando unicamente realizar o estudo sistemático de valores limites para as propriedades mecânicas.

$\mathrm{Na}$ prática, essas limitações traduzem-se pelo aparecimento de trincas de superficies, defeitos internos e fraturas. 
Preocupações com as distribuições de tensões e de deformações nos processos de conformação plástica, têm sido o centro das atividades para a aplicação da teoria da plasticidade dos metais. Deve-se sua importância às complexas formas de distribuição dessas tensões e deformações. Existem, também, preocupações para a determinação das forças de conformação, necessárias à obtenção de uma determinada forma intermediária ou final para um produto. Com o constante desenvolvimento de materiais metálicos, cada vez mais resistentes e, geralmente, de menor ductilidade, tornaram-se, também, mais importantes as preocupações com os estudos das distribuições de tensões e deformações na plasticidade (KACHANOV ${ }^{112}$ [1974]).

Durante o processo de conformação plásticạ, observa-se um aumento da resistência à deformção do metal, ao mesmo tempo que ocorre a diminuição da sua reserva plástica. As forças aplicadas crescem e, simultaneamente, a ductilidade disponivel diminui. Aliados a essas complexidades, tem-se o atrito na interface entre a matriz de conformação e a peça, e a variação geométrica da peça conformada.

os métodos de análise da conformação plástica estão intimamente ligados aos métodos de determinação da dïstribuição de tensões e de deformações na plasticidade, com a respectiva imposição de condicões de contorno ditadas pelas solicitações externas.

- conhecimento dessas distribuições de tensões e de deformações, tem sido necessário para os estudos e análise da conformabilidade.

Nem tudo tem sido fácil na análise dos processos de conformação plástica. Primeiramente porque $\circ$ próprio 
desenvolvimento da teoria da plasticidade mostra que ela não está unificada. Tem-se várias teorias e modelos, cujas aplicações dependem dos tipos de problemas a serem analisados. Além disso, outras dificuldades existem: a existência de vários tipos de processos de conformação, em que suas respectivas classificações variam de pesquisador para pesquisador (THOMSEN ${ }^{108}$ e BRESCIANI ${ }^{109}$ ); e o dificil problema de modelagem do atrito na interface peça-matriz, que provoca, com sua presença, distorções nas respectivas distribuições de tensões e de deformações.

Entre os vários métodos de análise das mencionadas variáveis de conformação plástica dos metais, dois têm se destacado como promissores. o primeiro é o método do limite superior (AVTIZUR $\left.{ }^{113}[1980]\right)$, adequado para o cálculo das forças e pressões necessárias à conformação plástica. Esse método consiste na aplicação do princípio variacional de PRAGER e HODGE ${ }^{114}$ [1951], em que se postula um campo de velocidades de deformação admissivel e pelo emprego da equação de continuidade obtém-se expressões para - cálculo das deformações. Acrescenta-se a isso a yexpressão que estabelece o critério de escoamento plástico e tem-se, como conseqüencia, as expressões entre as tensões e deformações. Isso fornece a potência interna de deformação. Finalmente, uma expressão variacional é estabelecida pela adição da potência externa fornecida e pela subtração da potência de atrito na interface. o método é analítico por natureza. o segundo método, o dos Elementos Finitos, é, também, baseado na aplicação do principio variacional, mas no caso, ele é de natureza basicamente numérica. Foi populärizado nas aplicações da: teoria da elasticidade e na da análise estrutural. Já a sua aplicação na plasticidade dos metais sofre grandes restrições, ditadas, 
principalmente, pelas dificuldades matemáticas; ou seja, devido a natureza dissipativa "àa plasticidade, não existe, ainda, uma formulação variacional completa para os problemas hiperbólicos dos tipos existentes no escoamento de plástico nos sollidos (GOMEs e BRESCIANI ${ }^{115}$ [1990]). Também no caso do método dos elementos finitos, é ainda dificil modelar as expressões da plasticidade dos metais, pois os mesmos, quando no estado plástico, apresentam, no comportamento plástico, fortes dependências de suas microestruturas constituintes. Mesmo com essas restrições, ZIENKIEWICZ ${ }^{116}$ [1977], discute teoricamente a aplicaçāo do método dos Elementos Finitos na plasticidade. O método dos Elementos Finitos opera de modo inverso ao do limite superior, ou seja, é imposto ao sólido umâ possivel função, de deslocamento, que deve satisfazer a continuidade e ser compativel dentro de cada elemento. A seguir, são aplicadás as solicitações externas e as condiçōes de contornos, uma modelagem para as expressões constitutivas elasto-plásticas é formulado e, então, após o processamento computacional, obtém-se os resultados das distribuiçōes de tensões e formulações.

outros métodos existem e são bastante utilizados, como: método da energia de deformação plástica uniforme, método da divisão em elementos, método da visio plasticidade e método das linhas de deslizamentos.

Apesar das jimitações dos métodos do Limite superior e dos Elementos Finitos, ambos são bastante difundidos e sofrem constantemente importantes reformulações. AVITZUR. e VANTYNE ${ }^{117}$ [1982] discutem uma completa análise pelo método do Limite superior e OH, PARK, KOBAYASHI e ALTAN ${ }^{18}$ [1983] apresentam uma aplicação do método dos Elementos Finitos, para simular o 
escoamento plástico de metal no forjamento de uma liga de titánio. CARTER Jr e LEE ${ }^{119}$ [1985] apresentam uma análise do uso do método dos Elementos Finitos na conformação por compressão de um cilindro e um anel, através do programa ADINA. :

Acrescente-se que, de todos os métodos existentes, o dos Elementos Finitos é o mais indicado para a análise de fratura na conformação plástica, segundo uma linha de simulação. Mas, no presente, o mesmo deve ser comparado com os valores possiveis de serem obtidos através de experimentos.

\section{4. Conformabilidade Prástica dos Metais}

$\operatorname{DIETER}^{120}$ [1984] afirmou que o termo "conformabilidade" é, dentro da metalurgia mecânicà, de ampla conotação descritiva, mas de definição cientifica vaga. Outros termos na metalurgia também apresentam essa caracteristica de imprecisão, tais como: dureza, maleabilidade, ductilidade e outros.

A conformabilidade está intrinsicamente ligada à ductilidade e aquela ainda apresenta um conceito mais amplo do que esta, pois está diretamente relacionada com o- processo de conformação plástica.

A ductilidade não é adequada para os estudos de conformabilidade, porque a mesma é oriunda de um conceito qualitativo, baseado numa definição ampla, dada por DIETER $^{121}$ [1968] como sendo: "A ductilidade é basicamente a capacidade de um metal se deformar plasticamente, sem a ocorrência de fratura, num ensaio de tração com corpo de prova normalizado". Essa definição de ductilidade é subjetiva porque depende de vários fatores, que deverão ser pré-fixados, de acordo com ROGERS ${ }^{122}$ [1968], que são: tipo de material metálico, dimensões do corpo de 
prova, taxa de deformação imposta no ensaio, temperatura de corpo de prova no ensaio, microestrutura metalúrgica e também do estado de tensão imposto no ensaio, devido a geometria do corpo.

- estudo da conformabilidade seguiu após is estudos de ductilidade pela análise e observação dos mecanismos de fraturas dúcteis. Foi intensificado, principalmente, por McCLINTOCK ${ }^{108}$ [1968] 'partindo da análise que após a nucleação de trincas, formavam-se no corpo cavididades cilindricas, que entre suas paredes davam origem a micro corpos de prova de tração, inseridos em uma matriz plastificada de metal. 'Foi construido um mecanismo de crescimento e coalescência desses vazios, que resultavam como conseqüência a propagação de trincas, levando à fratura do material. Foram pesquisadas por BATES $^{123}$ [1981], MCCLINTOCK ${ }^{124}$ [1971], KNOTT ${ }^{125}$ [1980] e VAN STONE ${ }^{126}$ et alii [1985], questões relativas sobre como esses vazios são nucleados e seus respectivos mecanismos.

As variáveis importantes na conformabilidade são: critério de escoamento plástico e respectiva tensão limite de escoamento, taxas de "deformaçōes, condições de atrito nas interfaces, temperatura de conformação plástica, tipo de fratura a se observar, dúctil ou frágil 'e, também, a caracteristica das microestruturas, das quais as fraturas dúcteis são altamente dependentes.

Dentro desta revisão, um dos conceitos de conformabilidade a ser adotado será o proposto por DIETER, ${ }^{120}$ que define a conformabilidade como sendo o grau de conformação a ser alcançado num processo de conformação plástica, sèm que haja a criação de condiçōes indesejáveis no material conformado como: trincas, fraturas, péssimo acabamento superficial, vazios internos 
e falta de enchimento na matriz.

Essa definição de DIETER é muito qualitativa e uma mais especifica a ser adotada será a de $\operatorname{KUHN}^{127}$ [1978], na qual a conformabilidade é a quantidade de deformação plástica que pode ser atingida num processo especifico de conformação plástica de um metal, sem a correspondente propagação de possiveis trincas existentes no material.

As duas definições de conformabilidade originam dois pontos de vistas diferentes de análise, mas ambós baseados em conceitosde ductilidade. o primeiro ponto de vista é o da definição de conformabilidade dada por $\operatorname{DIETER}^{120}$, que é baseado nos estudos dos mecanismos de fratura. Destes o mais importante é - proposto por MCCLINTOCK ${ }^{100}$, para o qual a fratura ocorre pelo crescimento e colapso de vazios dentro de uma matriz plastificada do metal. Um critério independente de conformabilidade foi proposto por COCKCROFT' é LATHAN ${ }^{128}$ [1968], analogamente à energia de deformação plástica do material, após ser solicitado externamente. Essa analogia ocórre porque o critério é baseado numa tensão de tração secundária.

Em 1979, OH, CHEN e KOBAYASHI ${ }^{129}$ propuseram um critério de conformabilidade baseado na unificação do critério de fratura dúctil de MCCLINTOCK e no de conformabilidade de cOCKCROFT e LATHAM. Em 1988, ZAVAGLIA ${ }^{131}$ ampliou a aplicação do critério de conformabilidade pela modificação dos critérios de oH, CHEN e KOBAYASHI e de COCKCROFT e LATHAM, pela sistematização de um procedimento que permitiu a incorporação de outros mecanismos de

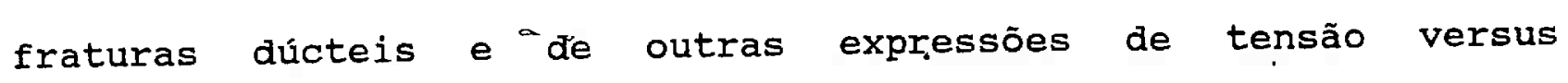
deformação, que a tradicionalmente utilizada relação de HoLLomoN. - segundo ponto dé vista para a análise da 
conformabilidade, é baseado em modelos macroscópicos, pela construção de curvas limites de conformabilidade, cujos ensaios sejam semelhantes aos próprios processos de conformação plástica em estudo.

Esse segundö "critério é um. mapeamento de estados de deformações, combinando processos e materiais.

KUHN $^{127}$ propōe ainda úma expressão generalizada para análise da conformabilidade da forma:

Conformabilidade $\equiv \mathrm{w}_{1}$ (material) $-\mathrm{W}_{2}$ (processo)

$\mathrm{W}_{1}=$ função ductilidade básica do material

$\mathrm{W}_{2}$ = função do sistema de tensão e deformação imposta no processo de conformação plástica

A função $w_{1}$ pode ser um critério de fratura e isso permite a introdução-de um terceiro ponto de vista, mas agora baseado na mecânica da fratura não-linear elasto-plástica.

Uma modificação na definição de kUHN da conformabilidade faz-se necessária para introduzir formalmente esse terceiro ponto de vista:

A conformabilidade é a quantidade de deformação plástica expressa em função de uma integral invariante, que pode ser atingida num processo especifico de conformação plástica de um metal, sem a correspondente propagação de trincas existentes.

A determinação da conformabilidade passa agora a ser procedimento complexo, pois envolve na análise dạ conformação plástica a avaliação dạ ductilidade e a aplicação dà mecânica da fratura no processo com o objetivo de possibilitar a construção de diagramas de conformabilidade para as aplicações industriais. 


\section{REFERENCIAS BIBLIOGRAFICAS - CapItulo 1}

1. ALTAN, T.; OH, SOO-IK; GEGEL, H.I. Metal Forming: fundamentals and applications. Metals Park, American Society. for Metals, 1983 .

2. HILL, R. The Mathematical' Theory of Plasticity. Oxford, Clarendon, 1950. p.128-160

3. Coulomb, C.A. Mémoires Mathematics et Physics, 7 (343), 1773.

In: HILL, R. op. cit., ref. (2) - capitulo 1, p.1-13.

4. PONCELET, J.V. [1840] \& RANKINE, W.J.M. [1856]. In: HILL, R. op. cit., ref. (2) - capitulo 1, p. 1-13

5. TRESCA, H. Sur l'encoulement des corps solids soumis à de forte pression. Comptes Rendus Hebdomadaires des. Séances de 1'Academie des sciences, Paris, 59:754, 1864.

6. SLATER, R.A.C. Engineering Plasticity: theory and application to metal forming processes. London, McMillan, 1977.

7. HUBER, M.T. Czasopismo techniczne, 22(81), 1904. apud JoHNSON, W. \& MELLOR, P.B. Engineering Plasticity. Chichester, Ellis Horwood, 1983.

8. SAINT-VENANT, B Mémoire sur 1'établissement intéríieurs opéres dans les corps solides ductiles au delà des limites ou l'élasticité pourrait les ramener à leur premier état. Comptes Rendus Hebdomadaires des Séances de 1'Academie des sziences, Paris, 70:473, 1870.

9. LEVY, M. Mémoire sur les équations générales des mouvements intérieurs des corps solids ductiles au delà des limites ou l'élasticité pourrait les ramener à leur premier état. Comptes Rendus Hebdomadaires des Séances de 1'Academie des Sciences, Paris, 70:1323, 1870.

10. HAAR, A. \& VON KARMAN, T. Zur theorie der sparinungszustände 
in plastischen und sandartigen medien. Göttinger Hachrichten Mathematisch - Physikalische Klasse. Göttinger, 20:204-218, 1909.

11. VON MISES, R. Mechanik der festen körper. In: Plastich Deformablen zustant. Göttinger Hachrichten, Mathematish Physikalische Klasse, Göttingen, 582, 1913. Apud: SLATER, R.A.C., Op. cit., ref. (7) - capitulo 1 .

12. HENCKY, H.Z. Zur theorie plastischer deformationen und der hierduch im material hervorgerufenem nebehspannunger. Zeitschrift für Angewandte Mathematik und Mechanik, Berlin, 4:323, 1924. In: SLATER, R.A.C. Op. cit., ref. (7) e HILL, R. op. cit. ref. (2).

13. PRANDTL, L. Ûber de härte plastischer körper im plastisch deformablem zustant. Göttinger Nachrichten, Mathematisch Physikalische Klasse, Göttingen, 74, 1920. In: HILL, R. op. cit., ref. (2)

14. Ûber einige statisch bestimmte fälle des gleichgewichts in plastischen körpen. zeitschrift für Angewandte Mathematik und Mechanik, Berlin, $3: 241,1923$. In: SLATER, R.A.C. op. cit., ref. (7)

15. GERINGER, H. Beitrag zum vollständigen ebenen plastizitäts problem. Proceedings. 3rd International Congress of Applied Mechanics. Stockholm, 1930. vol. 2. p.185.

16. VON KÁRMÁN, T. Beitrag zur theorie des walzvorganges. Zeitschrift für Angewandte Mathematik und Mechanik, Berlin, $\underline{5}: 130,1925$.

17. SACHS, G. Beitrag zur theorie des ziehvorganges: Zeitschrift für Angewandte Mathematik und Mechanik, Berlin, $\underline{7}: 235$, 1927. 
18. SIEBEL, E. The plastic forming of metals. Translated by HITCHCOCK. Steel, Oct.16, 1933/May 7, 1934.

19. CARRIER, G. F. and PEARSON, C. E. Partial Differential Equations: theory and technique. 'New York, Academic Press, 1976. pp.75-39 e 227-256

20. KACHANOV, L.M. Fundamentals of the Theory of Plasticity. Moscow, Mir, 1974. pp.148-342

21. LUDWICK, P. Elemente der Technologischen Mechanik, Berlin, Verlag Julius springer, 1909. In: KACHANOV, I.M. Op. cit. ref. (20)

22. HOLLOMON, J.H. Tensile deformation. Transactions of AIME, $162: 268-290,1945$.

23. VOCE, E. The relationship between stress and strain for homogeneous deformation. The Journal of the Institute of Metals, 74:537-562, 1948.

24. SWIFT, H.W. Plastic instability under plane stress. Journal of Mechanics and Physics of Solids, 1(1):1-18, 1952.

25. RAMBERG, W. and OSGOOD, W. Description of stress-strain curves by three parameters. NACA TN 902, Jul.1943.

26. KLEEMOLA, H.J. and NIEMINEN, M.A. On the strain-hardening parameters of metals. Metallurgical Transactions, 5:18631866, Aug. 1984 .

27. PRAGER, $W$. On isotropic materials with continuous transition from elastic to plastic state. 5th International Congress of Applied Mechanics, Cambridge, MA, 1938. pp.234-237

28. BAUSCHINGER, J. Û̉bĕr die Veränderung der Elastizitätsgrenze und des Elastizitätsmoduls Verrschiedener Metalle, Civilingineur, 1881. pp.289-348. In: ZYCZKWOSKI, M. op. cit. ref. (29) 
29. ZYCZKwOSKI, M. Combined Loadings in the Theory of Plasticity. Varsovia, PWN-Polish Scientific Publishers, 1981.

30. MASSING, G. Zur Heyn'schen Theory der Verfestigung der Metalle durch Verborgen Elastischer spannungen. Wissenschaftliche Veröffentlichungen Siemens Konzern. $3(3), 1923$.

31. ABEL, $A$. and MUIR, $H$. The Bauschinger and stacking fault energy. Phylosophic Magazine, 27(3):585-594, 1973.

32. LEVY, M. Mémoire sur les équations générales. Coimptes Rendus Hebdomadaires des seances de I'Academie des Sciences, Paris, $\underline{70}: 1323-1325,1870$.

33. VON MISES, R. Mechanik der festen Köper im plastish deformablem zustand. Göttinger Nachrichten, Mathematisch Physikalische Klasse, I(4):582-592, 1913.

34. PRANDTL,L. Spannungsverteilung in plastischen Körpern. Proceedings of $I^{\text {st }}$ International congress of Mechanics. Delft, 1924. pp.43-54. Op. cit. Ref. (20)

35. REUSS, A. Berücksichtigung der Elastichen Formäderungen in der Plastizitätstheorie. Zeitschrift für Angewandte Mathematik und Mechanik, Berlin, 10(3):266-274, 1930.

36. DIETER, G.E. Mechanical Metallurgy. 2.ed. New York, McGraw$-\mathrm{Hill}, 1976$.

37. NADAI, A. Theory of Flow and Fracture of Solids. New York, McGraw-Hill, 1950. vol.1

38. LODE, $W$. Versuche über den Einfluss der mitteleren Hauptspannung für̆ Angemandte Mathematik unid Mechanik, Berlin, vol.5, 1925. Op.cit. in zyczkowski. Ref.29.

39. VON MISES, R. Mechanik der Plastischen Formänderung von Kristallen. Zeitschrift für Angewandte Mathematik und Mechanik, Berlin, $\underline{8}(3): 161-185,1928$. 
40. NADAI, A. Der Beginn des Fliessvorganges in einem tordiertem stab. Zeitschrift für AngewandteMathematikund Mechanik, Berlin, $\underline{3}(6): 442-444,1923$.

41. ILYUSHIN, A.A. Some problems of plastic deformations, (in Russian), PM M-Prikladnayá Matematika i Mechanika, Moscow, Z (4):245-272, 1943 .

42. Relation between the saint Venant-Levy-Mises theory and the theory of small-elastic-plastic deformations. (in Russian). PMM-Priladnaya Matematika i Mechanika. Moscow, $\underline{9}(3): 207-218$.

43. Theory of plasticity at simple loading of the bodies exhibiting, plastic hardening (in Russian), PMM-Prikladnaya Matematika i Mechanika, Moscow, 11(2):291-296, 1947.

44. - On the eheory of small elastic-plastic deformations (in Russian), PMM-Prikladnaya Matematik i Mechanica. Moscow, $10(3): 347-356,1946$.

45. HILI, R. Theoretical plasticity of tectured. aggregates, Mathematical proceedings of Cambridge Phylosofical society. 85: $179-191,1978$.

46. GOL'DENBLATT, I. I. Some problems of the mechanics of deformable media. Holland, Noordhoff, 1962.

47. ZIENKIEWICZ, O.C. The finite element method. 3. ed. London, McGraw-Hill, 1977.

48. PRAGER, W. and HODGE, P.G. Theory of Perfectly Plastic solids. London, Chapman $\mathrm{Hall}, 1951$.

49. AVITZUR, B. MetalForming: processes and analysis. NewYork, McGraw-Hill, 1968.

50. DRUCKER, D.C. Stress-strain relations in the plastic range of metals - experiments and basic concepts. EỊRICH, F.R. 
(editor). Rhoelogy-theory and applications, Academic Press, vol.1, 1956. pp. 217-226

51. D.C. A definition of stable inelastic material. Journal of Apllied Mechanics, 26(1):101-106, 1959.

52. KOITER, W. T. stress-strain relations, uniqueness and variational theorems for elastic plastic materials with singular yield surface. Quality Journal of Apllied Mathematics, $3(3): 350-354,1953$.

53. HENCKY, H. Über die form des Elastizitätsgesetzes bei Ideal Elastischen stoffen. Zeitschrift für Technische Physik. $\underline{9}: 214-223,1928$.

54. NADAI, A, Plastic behavoiur of metals in the satrain-hardening range. Part I, Journal of Applied Physics, 8:205-217, 1937. 55. HIRTH, J.P. and LOTHE, J. Theory of dislocations. New York, McGraw-Hill, 1968. pp.1-57.

56. MÜGGE, O. Op.cit. in HIRTH, J.P. and LOTHE, J., Ref.55, p. 3 .

57. LOVE, A.E.H. The Mathematical theory of elasticity. Cambridge University. Cambridge,1927, artigo 156A. pp.15̣0-235.

58.NABARRO, F.R.N. Theory of crystal dislocation. oxford, Clarendon Press, 1967. pp.1-52

59. TAYLOR,G.I. Mechanism of plastic deformation.: of crystals. Proceedings of Royal Series A145. (362), 1934. Op.Cit. in NABARRO,F.R.N., Ref.58. pp.5-7.

60. OROWAN,E. Zeitschriff für Physik. Berlin, vol.89, p.634, 1934. Op.Cit. in NABARRO, F.R.N. Ref.58, pp.5-7.

61. POLANY, M. Zeitschrift für Physik, Berlin, vol.89, 1934, p.660. Op. Cit. in NABARRO,F.R.N., Ref.58, pp.5-7.

62. FRENKEL, J. Zeitschrift für Physik, Berlin, vol.37, 1926, p.572. op.Cit. in HIRTH, J.P. and LOTHE, J.Ref.55, 
pp. 6-7.

63. MACKENZIE, J.K. Tese de Doutorado não publicada, Universidade de Bristol, Inglaterra, 1949. Op.Cit. in HIRTH,J.P. and LOTHE, J., Ref.55, p.7.

64. BRENNER, S.S., in DOREMUS, R.H. et alii... (editors), Growth and Perfection of Crystals. New York, John Wiley, 1958. p.3. 65. BURGERS, J. M. Proceedings Kon. Ned. Akad. Wetenschap, vol.42, 1939, n.378, op. Cit. in NABARRO, F.R.N., Ref.58, pp.1-16.

66. ESHELBY, J.D. The coninuum theory of lattice defects in SEITZ, F. and TURNBULL, D. Solid Physics: New York, Academic Press, 1956. vol.III, pp.79-144.

67. VOLTERRA, V. Ann. Éc. Norm. Sup. vol.24, 1907, pp.400. Op.Cit. i ESHELBY,J.D. Ref $66, \mathrm{pp} .90$.

68. SOMIGLIANA, C. Atti.Accad.Nozl. Lincei Rend. Classe sci. Fis. Mat. e Nat. $23(1), 1914$. Op.Cit. in ESHELBY, J.D. Ref. 66, 1956. pp. $89-91$

69. Id. Ibid. Ref.58, pp.20-21.

70. pp.53-119

71. NOETHER, R. Invariante Variations Probleme Göttinger Nachrichten, Mathematisch. Physikalische Klasse, vol.2,1918, p.235, op.Cit. in KNOWLES,J.K. and STERNBERG, E.; On a classe of conservation lows in linearized and finite elastostatics. Archive for Rational Mechanics and Analysis, $44(3): 187-211,1972$.

72. CUSHING, J.T. Applied Analytical Mathematics" for Physical Scientists. New York, John Wiley; 1975. pp.251-257

73. RICE, J.R. A path independent integral and the approximate analysis of strain concentration of the ASME. Journal of Applied Mechanics, 35(2):379-386, 1968 . 
74. CHEREPANOV,G.P. Crack propagation in continuous media. Journal of Applied Mathematics and,Mechanics (English translation of Soviet Journal PMM), 31(3):504-512, 1967.

75. SANDERS, J.L. On the Griffith - Irwin fracture theory. Translation of Applied Mechanics, 27(2):352-353, 1960.

76. BEGLEY, J.A. and LANDES, J.D. The J-integral as a fracture criterion. In: ASTM Fracture Toughness, Proceedings of the 1971, National symposium on Fracture Mechanics, Part II. ASTM-STP-514, American Society for Testing and Materials, 1972. pp. $1-20$

77. HUTCHINSON, J.W. Singular behaviour at the end of a tensile crack in a hadening material. Journal of the Mechnics and Physics of Solids, 16(1):13̧-31, 1968.

78. - Plastic stress and strain. Journal of the Mechanics and Physics of Solids, $16(1): 337-347,1968$.

79. RICE, J.R. and ROSENGREN, G.F. Plane strain deformation near a crack tip in a power-law hardening material. Journal of the Mechanics and Physics of Solids, 16(1):1-12, 1968.

80. KNOWLES, J.K. and STERNBERG,E. On a class of conservation law in Iinearized and finite elastostatics. Archive for Rational Mechanics and Analysis, 44(3):187-211, 1972.

81. BUDIANSKY, $B$ and RICE, J.R. Conservation laws and energy-realease rates. Translations "of the ASME, Journal of Applied Mechanics, 40:201-203, 1973.

82. AOKI, S.; KISHIMOTO, $K$ and SAKATA, M. energy flux into process region in elastic-plastic fracture problems: Engineering Fracture Mechanics, 19(5):827-836, 1984 .

83. FUNG, Y.C. Foundations of solid mechanics. 'New Jersey, Prentice-Hall, Englewod Cliffs, 1965. pp.31-18̣2. 
84. GRIFFTHS, A.A. The phenomenon of rupture and flow of solids. Philosophical Transactions of Royal Society, London, 221A: $163-198,1920$.

85. INGLIS, C.E. Stress in a plate due to the presence of cracks and sharp corners. Translations of the Institute of Naval Archictets, 60:219-230, 1913 .

86. PARTON, V.z. and MOROZOV, E.M. Elastic-Plastic Fracture Mechanics, Moscow, Mir, 1974. pp.15-36

87. SACK, R.A. Procedings of Physical Society of London, 58:729, 1946.

88. MOTT, N.F. Engineering, 165:16, 1948.

89. OROWAN, E. Energy criteria of fracture. Welding Research Supplement, 20:1575-1605, 1955.

90. WILIIAMS, M.L. On the stress distribution at the base of a stationary crack. Trasnlations of the ASME, Journal of Apllied Mechanics, 24:109-114, 1957.

91. IRWIN, G.C. Analysis of stresses and strains near the end of a crack tranversing a plate. Translations of the ASME, Journal of Applied Mechanics, 24:361-364, 1957.

92. SNEDDON, I.N. The distribution of stress in the neighbourhood of a crack in an elastic solid. Proceedings of Royal Society $A$, London, 1946. pp. 229-260

93. ASTM standard têst methos for $J_{T C^{\prime}}$ a measure of fracture toughness. 1989 Annual Book of ASTM Standard. vol.03.01, American society for Testing and Materials,. Philadelphia, 1989.

94. PARKER, A.P. The Mechanics of Fracture and Fatique. Iondon, Spon, 1981. pp. 28-39 
95. SHAW, M.C. A critical review of mechanical failure criteria. Translactions of the ASME, Journal of Enginnering Materials and Technology, 106:219-226, 1984 .

96. MCMEEKING, R.M. Finite deformation analysis of crack tip opering elastic-plastic materials and implications for fracture. Journal of Mechanics and Physics, of Solids, $25: 357-381,1937$.

97. BEGLEY, J.A. and LANDES, J.D. The J-integral as a fracture criterion in ASTM, Fracture Toughness. Proceedings of the National Symposium on Fracture Mechanics, part II, 1971. ASTM STP 514, American Society for Testing and Material, 1972. pp.1-20 - .

98. RITCHIE, R.O. Why ductile fracture Mechanics. Transactions of the ASME Journal of Engineering Materials and Technology. 105:1-7, Jan.1983.

99. WILSDORF, H. G. F. The ductile fracture of metals: a microstructural view point. Materials science and Engineering, 59:1-39, 1983.

100. MCCLINTOCK,F.A. A criteriopn for ductile by the growth of holes. Translactions of the ASHE, Journal of Apllied Mechanics, 90:363-371, Jun.1968.

101. KNOTT, J.F. Micromechanisms of fibrous crack, extension in engineering alloys. Metal science, Aug-sep. 1980. pp.327-336 .

102. IRWIN, G. R. Fracture Mechanics. Methals Handbook. 9. ed., vol.8. Mechanical Properties, 1985. pp.440-464.

103. KEIM, E and MÜLLER, G. Nonlinear analysis" of fracture mechanics problems. Computer and structures. $32(3 / 4): 737-$ $-743,1989$. 
104. BROBERG, K.B. Crack growth criteria and nonline fracture mechanics. Journal of the, Mechanics and Physics of Solids. 19:407-418, 1971 .

105. AOKI, S.; KISHIMOTO, $K$ and SAKATA, M. Energy realise rate in elastic-plastic fracture problems. Transactions of the ASME, Journal of Applied Mechanics, 48:825-829, Dec. 1981. 106. KISHIMOTO, K; AOKI, S. and SAKATA, M. On the path independent integral J. Engineering Fracture Mechanics, 13:841-850, 1980.

107. BRUST JR, F.W. The use of new path independent integrals in elastic-plastic and creep fracture. PhD Thesis, Georgia Institute of Technology, Nov. 1984 .

108. THOMSEN, E. G.; YANG, $c_{;}$T. and KOBAYASHI, s. Plastic Deformation in Metal Processing. New York, MacMillan, 1965. pp. $158-216$

109. BRESCIANI FILHO, E. (coord.) Conformação Plástica dos Metais. Campinas, SP, Editora da UNICAMP, 1986. pp.86-101

110. JOHNSON, $\mathrm{W}$ and MELLOR, P. B. Engineering Plasticity. Chichester, England, Ellis Horwood, 1983. pp.23-27

111. POLUKHIN, P.; GORELIK, S. and VORONTSOV, V. Physical Principles of Plastic Deformation. AFANASYEV, V. (tradutor), Moscow, Mir, 1983. pp.180-218

112. KACHANOV, L.M. Fündamentals of the Theory fo Plasticity. Moscow, Mir, 1974. pp.48-105

113. AVITZUR, B. Metal Forming: the application of limit analysis. New York, Marcel Dekker, 1980.

114. PRAGER, W. and HODGE, P.G. Theory of Perfectly Plastic Solids. New York, John Wiley, 1951.

115. GOMES, E. e BRESCIANI FILHO, E. Projeto $e$ análise da 
conformação plástica dos metais pelo método dos elementos finitos não-lineares. Trabalho a ser apresentado no IV Simpósio de Conformação Plástica dos Metais, a ser realizado de 26 a 28 de novembro de 1990, na Escola Politécnica da Universidade de são Paulo, SP.

116. ZIENKIEWICZ, O.C. The Finite Element Method - Chapter three: Generalization of the Finite Element Concepts - Weighted Residual and Variational Approaches. London, McGraw-Hill, 1977. pp.42-92

117. AVITZUR, B. and VAN TYNE, C.J. Ring forming an upper bound approach. Part $\dot{i}$ : Flowpattern and calculation of power; Part 2: Process analysis and characteristics; Part 3: constrained forging abd deep drawing applications. Transactions of the ASME, Journal of Engineering for Industry, 104:231-252, 1982 .

118. OH, S.I.; PARK, J.J.; KOBAYASHI, S. and ALTAN, T. Application of FEM modeling to simulate metal flow in forging a titanium alloy engine disk. Transactions of the ASME, Journal of Engineering for Industry, 105:251, 1983.

119. CARTER JR., W.T. and LEE, D. A finite element analysis of cylinder and ring compression and its experimental verification. Computer and structures, 21(1/2):1-19, 1985. 120. DIETER, G. Chapter 1 - overview of workability. In: DIETER, G. (ed.) Workability Tésting Techniques. Metals Park, American Society for Metals, 1984. p.1-20

121. DIETER, G. Introduction to Ductility. In: 'PAXTON, H.W. Ductility. Metals Park, Ohio, American Society for Metals, 1968. pp.1-30

122. ROGER, H.C. The effect of material variables on ductility. 
In: PAXTON, H. Wr Ductility. Metals Park, Ohio, American Society for Metals, 1968. pp.31-61

123. BATES, R.C. Mechanics and thechanisms of fracture. In: TIEN, J.K. and ELLIOTT, J.F. (eds.) The Metallurgical Treatise. Presentations at the USA-China Bilateral Conference sponsered by the Metallurgical society of the AIME the American Society for Metals and Chinese Society of Metals, AIME, New York, 1981. pp.551-570

124. MCCLINTOCK, F.A. Plasticity aspects of fracture. In: LIEBOWITZ, H.(ed.) Fracture: an advanced treatise. Academic Press, 1971. vol. 3. pp.47-158

125. KNOTT, J.F. Micromechanisms of fibrous crack extension in engineering alloys. Metal Science, Aug/Sep.1980. pp.327-336 126. VAN STONE, R.H.; COX, T.B.; LOW JR., J. and PSIODA, J.A. Microstructural aspects of fracture by dimpled rupture. International Metals Review, 30(4):157-179, 1985.

127. KUHN, H.A. Workability testing and analysis for bulk forming processes. In: NIEMEIER, B. A. ; SCHMIEDER, A.K. and NEWBY, J.R. (eds.) Formability Topics-metalic materials. ASTM STP 647, American Society for Testing and Materials, 1978. pp. $206-219$

128. COCKCROFT, M.G. and LATHAN, D.J. Ductility and Workability of Metals. Journal Institute of Metals, 96:33, 1968.

129. OH, S.I.; CHEN, C.C. and KOBAYASHI, s. Ductility fracture in axisymmetric extrusion and drawing, part 2: 'ंorkability in extrusion and drawing. Transactions of the ASME, Journal of Engineering for Industry, 101:36-40, 1979. 


\section{ESTABELECIMENTO DO PROBLEMA}

\subsection{Definiçరిes}

Não se passou muito tempo desde que TEGART ${ }^{1}$ [1968] caracterizou as propriedades da conformação plástica de um material metálico, como sendo constituido de duas partes: a resistência ao escoamento plástico e a ductilidade. A resistência do escoamento plástico determina a capacidade do equipamento necessário para a operação de conformação; e a ductilidade estabelece a máxima deformação plástica permitida, sem que haja ocorrência de fraturas ou trincas.

COCKCROFT $^{2}$ [1968] definiu da seguinte forma o conceito de conformabilidade plástica: é 'a máxima deformação imposta a um material metálico, por um processo de conformação, sem que ocorra - surgimento de trincas visiveis. Esta definição relaciona a deformação plástica com a distribuição de tensões devido às solicitações externas, impostas pelo processo de conformação.

Segundo NIEMEIER e NEWBY $^{3}$ [1978], essas definições não passam de conhecimentos intuitivos sobre a conformabilidade plástica, no sentido de que conformar um metal para uma nova forma, consistia na transição da conformação de uma forma obtida anteriormente.

Um bom método de determinação da conformabilidade deve considerar os mecanismos de propagação de trincas para se evitar o máximo possível, os de tentativas e erros.os métodos de determinação e avaliação da conformabilidade, baseados nas definições de TEGART ${ }^{1}$ e COCKCROFT $^{2}$ não consideram os mecanismos de fratura de VAN STONE ${ }^{4}$ e colaboradores [1985].

DIETER $^{5}$ [1985] redefine a conformabilidade como sendo uma 
propriedade complexa, que tenta avaliar a ductilidade básica de um material, submetido a um estado de solicitação externa imposta por um processo, tal que o objetivo seja o desenvolvimento de um critério de fratura.

A definição de DIETER ${ }^{5}$, elimina o empirismo no estudo da conformabilidade $e$ estabelece uma base tecnológica para, principalmente, permitir a construção do critério de conformabilidade por analogia energética proposto por cockCROFT e LATHAN ${ }^{6}[1968]$.

\subsection{O Problema}

Na generalização da definição de conformabilidade, sem a violação da definição sproposta por DIETER, surge o problema objeto deste trabalho.

A conformabilidade é, uma propriedade complexa, que medindo a ductilidade básica do material metálico, em um processo de conformação plástica, pode ser avaliada pela aplicação das propriedades invariantes do material, de modo que, após a nucleação de trincas, estas propagam-se provocando uma variação de energia no processo, associada a uma taxa de liberação de energia, pela formação de superficies livres no material.

\subsection{Objetivos do presente trabalho}

É objetivo deste trabalho modelar $e$ estabelecer procedimentos experimentais para permitir a construção de mapas de conformabilidade plástica dos metais, através da mecânica da fratura não-linear elasto-plástica,e por meio de: ensaios de compressão de corpos cilíndricos padronizados. 
E objetivo também, avaliar analiticamente as limitações da teoria geral da plasticidade e as razões da impossibilidade de obter-se curvas de conformabilidade,através dela, mesmo com a aplicação dos métodos variacionais disponíveis.

Este trabalho deve, ainda, proporcionar o surgimento de uma metodologia de ensaio, apresentando um elevado grau de rigor técnico,e sendo de baixo custo e simples para ser realizado com os equipamentos comuns de pequenas instalações industriais.

\subsection{Justificativa}

- processo de conformação plástica dos metaís é hoje um dos mais difundidos processos de fabricação mecânica. Empreendimentos industriais de grande ou pequeno porte, dele se utilizam para a fabricação de peças e produtos acabados ou semi-acabados, com os mais variados tipos de materiais metálicos, que apresentem uma ductilidade aceitável, algumas vezes estebelecida para valores 'de redução de área no ensaio de tração, acima de $20 \%$.

A possibilidade do processamento do material metálico pela conformação plástica é garantida pelos" valores de propriedades mecânicas, obtidas em ensaios de tração, compressão e torção padronizados. Mas, a melhoria nas propriedades mecânicas, na qualidade, no acabamento, além de um alto grau de conformação a ser obtido, depende da propriedade da conformabilidade plástica. Essa propriedade da conformabilidade, para ser realista, deve ser obtida atravês" de mapas construidos a partịr de valores obtidos em ensaios representativos dos processos, mesmo em escala laboratorial. 
Uma condição extremamente severa de conformação plástica e possível de ser analisada, tanto analítica, quanto experimentalmente, é o ensaio de compressão de corpos de provas cilindricos padronizados, representativo para simular o forjamento de farugo cilindrico em matriz aberta e plana, sob as mais variadas condições de carregamento, atrito e temperatura.

Como a mecânica da fratura trata dos problemas de propagacão de trincas e não de sua nucleação, como utilizada neste trabalho; e,considerando que os limites de conformabilidade, construidos através de ensaios, são baseados no surgimento de trincas ou na fratura dos espécimens, é um tanto previsivel que as "duas" estejam de algum modo acopladas. Esse acoplamento, como observar-se-á, estará dịretamente vinculado às integrais invariantes. 


\section{REFERENCIAS BIBLIOGRAFICAS - CapItulo 2 ;}

1. TEGART, w.J. The role of ductility in hot working. In: PAXTON, H.W. (coord.) Ductility. Metals Park, Ohio, American Society for Metals, 1968. pp.133-177

2. COCKCROFT, M.G. Ductile fracture in cold working operations. In: PAXTON, H.W. (coord.) Idem. Ref. (I). pp.199-225

3. NIEMEIER, B.A. and NEWBY, J.R. Introduction. In: NIEMEIER, B.A.; SCHMIEDER, A.K. and NEWBY, J.R. Formability Topics metallic materials. Metals Park, ohio, American society for Metals, 1978. pp.1-3

4. VAN STONE, R.H.; COX, T.B.; LOW, J.R. and PSIODA, J.A. Microstructural aspects of fracture by dimple rupture. International Metals Review, $30(4): 157-179,1985 . *$

5. DIETER, G.E. (ed.). Workability Testing Techniques. Metals Park, Ohio, American Society for Metals, 1984. pp.1-2

6. COCKCROFT, M.G. and LATHAN, D.J. Ductility and the workability of metals. Journal of Institute of Metals, 96:33-39, 1968. 


\section{MECANICA DA CONFORMAÇX̃o PLASTICA dOS METAIS}

\subsection{Conceitos Fundamentais}

Na análise da conformação plástica, segundo JoHNSON e MELLOR ${ }^{1}$, convenciona-se que o processo é considerado como trabatho a frio se a temperatura do sólido for inferior a $30 \%$ da temperatura de fusão do metal base, o constituinte em maior porcentagem em peso na liga; portanto, essa temperatura deve ser abaixo da temperatura de recristalização dessa liga.

No processo "a*quente, acima da temperatura de recristalização, os mecanismos de deformações serão termicamente ativados, tornando muito mais complexas as avaliações analiticas e experimentais. Contudo, é necessário estabelecer relações constitutivas entre tensões e deformações na plasticidade dos metais que devem ser válidas tanto para o trabalho a frio como a quente.

A expressão mais geral já proposta por OR.LANDER ${ }^{2}$, que estabeleceu as influências da variação da entropia na ativação térmica por difusão; POLUKHIN ${ }^{3}$, que incluiu os mecanismos de deformação por modificações nas estruturas granulares; e por GAROFOLO ${ }^{16}$, que incluiu a taxa de deformação, segundo os mecanismos de fluência, é da forma:

$$
\frac{d}{d_{t}} \varepsilon_{1 j}^{k}=\sum_{k} Z_{k}(D, T, S) \sigma_{i j}^{k}(T, S) \exp \left\{\frac{-\Delta H k(T, S)}{R T}\right\}
$$

$t$, variável de evolução

$\mathrm{K}$ representa o K-ésimo mecanismo de deformação :

$\varepsilon_{i j}^{k}$ : tensor de deformações

$\mathrm{z}_{\mathrm{k}}$ : parâmetro microestrutural caracterizando as influências de tamanho de grão, dispersão $\epsilon$ ou precipitação de uma ou 
mais fases constituintes; densidade, distribuição e dimensões das discordâncias.

$\sigma_{1 j}^{k}$ : tensor das tensóves verdadeiras.

$\Delta \mathrm{H}_{k}$ : energia de ativação verdadeira.

$\mathrm{T}$ : temperatura absoluta.

$R$ : constante universal dos gases.

As representações gráficas da expressão (3.1) propostas por $A_{S H B Y}{ }^{5}$, são denominadas de mapas dos mecanismos de deformaçōes e são de grande utilidade na prática.

GAROFOLO indicou como limite para um processo ser ativado termicamente como sendo dado pela energia de auto-difusão,

$$
\ldots \mathrm{H}_{2} \simeq 338 \mathrm{~T}_{\substack{\text { fuszo } \\ \text { Deta } \\ \text { base }}}
$$

válida para:

$$
\mathrm{T} / \mathrm{T}_{\substack{\text { fusão } \\ \text { metal } \\ \text { base }}} \geq 0,46
$$

- processo de conformação é considerado 'a frio, de acordo com GANDHI e $\operatorname{ASHBY}^{6}$ [1979], se:

$$
T<(0,3 \text { a } 0,5) T_{\text {fusão }}
$$

A construção dos mapas dos mecanismos de deformações, segue 0 sugerido por $\operatorname{ASHBY}^{7}$ et alii, para metais e ligas. As relações de tensão versus deformação válidas para a análise dos processos de confirmação a quente são obtidas através dos mapas dos mecanismos de deformações. Esses mapas foram propostos por 
$\mathrm{ASHBY}^{5}$ em 1972 .

MILLER e LANGDON generalizaram a construção desses mapas de deformações, apresentando as duas seguintes expressões, obtidas da equação 3.1

$$
\dot{\varepsilon}_{A T}=A_{1} D_{o(1)} \exp \left\{\frac{-Q_{1}}{R T}\right\}\left(\frac{G b}{K T}\right)\left(\frac{T}{G}\right)^{n}
$$

e

$$
\dot{\varepsilon}_{B T}=50 A_{1} D_{O(g b)} \exp \left\{-\frac{Q_{g b}}{R T}\right\}\left(\frac{G b}{K T}\right) \cdot\left(\frac{\sigma}{G}\right)^{n+2} 3.3
$$

sendo:

$\mathrm{n}$ : constante do material relacionada com a sensibilidade à taxa de deformação

$D_{0}$ : fator de freqüencia relacionado ao coeficiente de difusão

Q: energia de ativação

$R$ : constante universal dos gases

T: temperatura absoluta

G: módulo de cisalhamento

$\mathrm{K}$ : constante de Boltzmann

A: constante adimensional

os subscritos 1 e gb, referem-se aos parametros de difusão de rede e de contornos de grãos, respectivamente, e os subscritos AT e BT indicam que os processos estão ocorrendo em altas temperaturas e baixas temperaturas, respectivamente.

Na tentativa de correlacionar dados experimentais em diferentes temperaturas e taxas de deformações, levaram ZENER e HOLLOMON $^{9}$ a proporem, desconsiderando a influência da microestrutura, o seguinte:

$$
\sigma_{\varepsilon=\text { constante }}=\mathrm{f}(\mathrm{Z})=\mathrm{f}\left\{\dot{\varepsilon} \exp \left(\frac{\mathrm{Q}}{\mathrm{RT}}\right)\right\}
$$


Z: parâmetro de ZENER-HOLLOMAN

DADRAS ${ }^{10}$ procurou uma, relação funcional mais ampla, segundo o modelo proposto por SELLARS e TEGARD ${ }^{11}$, onde:

$$
\mathrm{z}=\mathrm{A}\left[\operatorname{sen}\left(\mathrm{h} \alpha_{\mathrm{s}}\right)\right] \mathrm{n}^{\prime}
$$

A, $\alpha$ e $n^{\prime}$ são constantes materiais ajustáveis, após valores obtidos experimentalmente.

A expressão de DADRAS, em função do parâmetro de ZENER e HOLLOMON, é do tipo:

$$
\varepsilon^{\mathrm{P}}=\mathrm{KZ}^{\mathrm{B}}
$$

para $K$ e $B$ : ser também obtidos por experimentos. As relaçōs das equações $3.4 \mathrm{a}, 3.4 \mathrm{~b}$ e $3.4 \mathrm{c}$, apesar de simples, não consideram a influência da temperatüra, principalmente para procesṣos a quente. As relações de MILLER e LANGDON, equações 3.2 e 3.3 , correspondem em termos généricos, às expressões de superplasticidade dos metais, formuladas por SHERBY e WADSWORTH ${ }^{11}$, como sendo:

$$
\sigma=\left[\dot{\varepsilon} \exp \left(\frac{Q}{R T}\right)\right]^{\mathrm{m}} G \quad f(s)
$$

\section{$\sigma$ : tensão efetiva}

$\dot{\varepsilon}$ : taxa de deformação efetiva

G: módulo de cisalhamento

$\mathrm{R}$ : constante universal dos gases

$f(s)$ : função da microsstrutura, representando as influências do tamanho de grão, tamanho do subgrão e densidade de discordâncias.

m: parâmetro de sensibilidade à taxa de deformação,

$m \simeq 0,1$ para baixa taxa de deformação

$\mathrm{m} \simeq 0,5$ para alta taxa de deformação

A influência da temperatura na deformação plástica é 
considerada como sendo um fator acessório, caso o processo seja isotérmico. As modificações observáveis no comportamento dos materiais metálico levăm a um processo.com ativação térmica. caso haja a ocorrência de variações significativas na temperatura, a mesma deve ser considerada como uma variável independente. PRAGER ${ }^{12}$ propôs um método de análise para deformação plástica, com a seguinte superficie de escoamento:

$$
F\left(\sigma_{1,}, \varepsilon_{1 j}^{P}, W^{P}, T\right)=0
$$

$\sigma_{1 j}$ : tensor de tensões

$\varepsilon_{1 j}^{P}$ : tensor de deformações plásticas

$W^{P}$ : densidade da energia de deformação

$\mathrm{T}$ : temperatura

sendo:

$$
w^{P}=\int_{0}^{\varepsilon} \sigma_{1 j}^{\prime} \mathrm{d} \varepsilon_{11}^{P}
$$

$\mathrm{Na}$ superficie de escoamento não ocorre variação no trabalho plástico e na deformação plástica, tal que:

$$
\text { d } \varepsilon_{1 j}^{P}=0
$$

então:

$$
\frac{\partial F}{\partial \sigma_{1 j}} \mathrm{~d} \sigma_{1\}}+\frac{\partial F}{\partial T} d T=0
$$

- potencial plástico de VON MISES foi estabelecido como

sendo:

$$
g=g\left(\sigma_{i j}, K\right)
$$

onde:

K: critério de escoamento

A plasticidàdé associada dos metais é definida de tal modo que:

$$
F \doteq g
$$

Então, obtém-se após agrupamento de 3.8 e 3.9: 


$$
\mathrm{d} \varepsilon_{1,}^{\mathrm{P}}=\mathrm{d} \lambda \frac{\partial \mathrm{g}}{\partial \sigma_{11}}\left(\frac{\partial F}{\partial \sigma_{k 1}} \mathrm{~d} \sigma_{\mathrm{k} 1}+\frac{\partial \mathrm{F}}{\partial \mathrm{T}}\right)
$$

Em uma superficie de plasticidade $F$, em expansão, a variação é nula, então:

$$
\frac{\partial F}{\partial \sigma_{k 1}} d \sigma_{k 1}+\frac{\partial F}{\partial T} d T+\frac{\partial P}{\partial \varepsilon_{1 j}^{P}} d \varepsilon_{1 j}^{p}+\frac{\partial F}{\partial k^{P}} d \sigma_{1 j}^{\prime} d \varepsilon_{1 j}^{P}=0
$$

então, de 3.11 e 3.12 :

$$
\left(1+\frac{\partial F}{\partial \varepsilon_{1 j}^{P}}+\frac{\partial F}{\partial W^{P}} \sigma_{1 j}^{\prime}\right) d \lambda \frac{\partial g}{\partial \sigma_{13}}=0
$$

Então, o valor de dג em 3.13, quando substituido na equação 3.11, fornece a representativa variação da influência da temperatura no incremento de deformação plástica: :

$$
d \varepsilon_{1 j}^{p}=\frac{\frac{\partial g}{\partial \sigma_{1 j}}\left(\frac{\partial F}{\partial \sigma_{k 1}} d \sigma_{k 1}+\frac{\partial F}{\partial T} d T\right)}{\frac{\partial g}{\partial \sigma_{m n}}\left(\frac{\partial F}{\partial \varepsilon_{m n}^{P}}+\frac{\partial F}{\partial W^{p}} \sigma_{m n}\right)}
$$

É aparente a dificuldade que existe na manipulação algébrica dos problemas de incrementos de deformaçōes plásticas, dados pela equação 3.14, quando se tenta considerar os efeitos na deformação plástica, devido à influência da temperatura.

3.1.1. Comportamento dos Metais na Conformação a Frio

No caso do trabalho de plastificação a frïo, o conceito de potencial plástico de VON MISES, discutido por HILL ${ }^{13}$ e 
KACHANOV $^{14}$, é representado por equações de escoamento plástico da forma :

$$
d \varepsilon_{1 \jmath}^{P}=d \lambda \frac{\partial g\left(\sigma_{1,}, k^{2}\right)}{\partial \sigma_{1 j}}
$$

Por outro lado, em um meio metálico plastificado, existe uma superficie de escoamento, construida por um critério de escoamento construidó de tal forma que:

$$
-\check{f}\left(\sigma_{1 j}, k^{2}\right)=\frac{1}{2} \sigma_{1 j}^{\prime} \sigma_{1 j}^{\prime} \quad ; .
$$

usa-se $\mathrm{K}^{2}$, para evitar a imposição da condição $\mathrm{K}>0$.

sendo:

$$
\begin{aligned}
& \mathrm{K}=\bar{\sigma}_{0} / 3^{1 / 2} \\
& \bar{\sigma}_{0}=\text { tensão limite de escoamento, obtida por ensaios. } \\
& \sigma_{i j}^{\prime}=\sigma_{1 j}-\frac{1}{3} \sigma_{k k} \delta_{1 j}
\end{aligned}
$$

e

$$
\delta_{1 j}=\left\{\begin{array}{l}
0, \text { se } i \neq j \\
1, \text { se } i=j
\end{array}\right.
$$

$\delta_{1}$, é o delta de KRONECKER.

Na condição da plasticidade associada, a equação 3.11 , é modificada para a forma:

$$
g\left(\sigma_{1 j}, K\right) \equiv f\left(\sigma_{1\}}, K\right)
$$

a plasticidade é do tipo:

$$
\mathrm{d} \varepsilon_{1 \mathrm{p}}^{\mathrm{P}}=\mathrm{d} \lambda \frac{\partial \mathrm{g}}{\partial \sigma_{1 j}}\left(\sigma_{1,}, \mathrm{~K}\right)=\mathrm{d} \lambda \frac{\partial \mathrm{f}}{\partial \sigma_{1 j}}\left(\sigma_{1 \mathrm{j},}, \mathrm{K}\right)
$$


No caso da existência de cantos na superfície de escoamento, a seguinte condição se impõe:

$$
\mathrm{d} \varepsilon_{1,}^{\mathrm{P}}=\mathrm{d} \lambda_{1} \frac{\partial f}{\partial \sigma_{1,}}\left(\sigma_{1,}, \mathrm{~K}\right)+\mathrm{d} \lambda_{2} \frac{\partial f}{\partial \sigma_{1,}}\left(\sigma_{1,}, \mathrm{~K}\right)
$$

\subsubsection{Relaḉes da Plasticidade dos Metais}

As relações da plasticidade são dadas, na teoria incremental, pelas formulaçôes da elasto-plasticidade na forma:

$$
d \cdot \varepsilon_{1 j}=d \varepsilon_{i j}^{e}+d \varepsilon_{i j}^{p}
$$

onde:

de $\varepsilon_{19}$ : deformação incremental totaí

$d \varepsilon_{1 j}^{e}$ : deformação incremental elástica

$d \varepsilon_{1 j}^{p}$ : deformação incremental plástica

A forma mais geral segue a fornecida pela relação proposta por PRANDTL ${ }^{15}$ e REUSS ${ }^{16}$ :

$$
d \varepsilon_{1 j}=\lambda s_{1 j}+\frac{1}{2 G} d s_{1 j}
$$

$G=\frac{E}{2(1+v)}:$ é $\circ$ módulo de KIRCHHOFF

E: é o módulo de YoUNG

$v$ : é a razão de POISSON

A equação 3.20 é uma generalização da relação da deformação plástica incremental proposta por LEVY $^{17}$ e VON MISES ${ }^{18}$, baseada no conceito de potencial plástico introduzido pelo próprio VON MISES, onde é afirmado que: um potencial plástico existe se for possivel definir os componentes de um tensor de tensão de segunda ordem, como sendo as derivadas parciais de uma certa fun- 
ção escalar $g\left(\sigma_{1 j}\right)$, de tal modo que:

$$
g\left(\sigma_{1 j}\right)=\frac{1}{2} I_{2}\left(s_{1 j}\right)
$$

As equações do escoamento plástico incremental de LEVY-VON MISES são, então, da forma:

$$
d \varepsilon_{1 j}^{P}=\frac{\lambda}{2} \frac{\partial}{\partial S_{1 j}} I_{2}\left(S_{1 j}\right)=\lambda \frac{\partial g}{\partial \sigma_{1 j}}\left(\sigma_{1 j}\right)
$$

A função $g\left(\sigma_{1 j}\right)$ é o potencial plástico e é definida de modo a satisfazer a condição

$$
\frac{\partial d \varepsilon_{11}^{P}}{\partial \sigma_{k 1}}=\frac{\partial d \varepsilon_{k 1}^{P}}{\partial \sigma_{11}}
$$

A equação 3.22 define um espaço nono-dimensional pela forma vetorial seguinte:

$$
d \underline{\varepsilon^{p}}=\lambda \operatorname{grad} g\left(\sigma_{1 j}\right)
$$

Se ocorrer de $g\left(\sigma_{1 j}\right)=f_{k H}\left(\sigma_{1 j}\right)=$ constante, então, a expressão 3.24 mostra uma coñuição de normalidade de $\underline{\varepsilon}^{\mathrm{P}}$, num ponto dado pelo tensor de tensão $\underline{T}_{\sigma}$. A função $f_{M H}\left(\sigma_{1\}}\right)$ é na realidade o critério de escoamento plástico de VON MISES ${ }^{18}$ e HENCKY. ${ }^{19}$

Contrapondo à teoria incremental do escoamento plástico, existe a teoria da deformação plástica devido a $\mathrm{HENCKY}^{19}$. E um 
modelo de deformação elástica não linear, em que são desprezadas as irreversibilidades e trajetórias de carregamentos. É, também, a teoria da deformação plástica, válida para pequenas deformações elasto-plásticas, de tal modo que existe uma proporcionalidade entre os tensores das tensões reḍuzidas e do das deformaçōes, tal que:

$$
\mathrm{d} \varepsilon_{1 j}=\varphi \mathrm{s}_{1 \mathrm{j}}
$$

Em sua formulação mais geral, o modelo da deformação plástica considera o efeito da compressibilidade, formando uma expressão generalizada na forma:

$$
\varepsilon_{11}=\varphi \sigma_{1 j}+\left(\frac{1}{3 K}-\varphi\right) \sigma_{m} \delta_{1 j}
$$

A formulação de HENCKY, foi aplicada por NADAI [1923] no caso especifico do problema de torção.

Os trabalhos de ILYUSHIN ${ }^{41-44}$ contribuiram definitivamente para a transformação do modelo de HENCKY, de um de deformação plástica infinitesimal, para um modelo de elasticidade não-linear, estabelecendo uma independência entre os estados de deformaçōes final e inicial.

ZYCZKOWSKI ${ }^{21}$ denominou esse modelo de teoria das pequenas deformações elasto-plásticas de HENCKY-ILYUSHIN-NADAI.

Como no processo de deformação plástica surge uma nova equação condicional, ùmă nova variável.deve ser ințroduzida para a medida das mudanças de configuração ou forma do corpo metálico e, ao mesmo tempo, permitir à quantificação da dịstorção do 
material.

A variável desconhecida, até agora, é um coeficiente de proporcionalidade existente entre os tensores das tensōes reduzidas $s_{1\}}$ e o das deformaçõea. A multiplicação da equação 3.26 pelos componentes de si mesmo, no caso de incompressibilidade, tem-se:

$$
\varepsilon_{i j} \varepsilon_{1 j}=\varphi^{2} S_{1 j} S_{1 j}
$$

A deformação equivalente é definida como sendo:

$$
\varepsilon_{1 J} \varepsilon_{1 J}=4 / 9 \varepsilon_{\text {eq }}^{2}
$$

Por outro lado, a utilizaçãó do critério da distorção plástica de VON MISES - HENCKY, fornece:

$$
S_{1 j} S_{1 j}=\sigma_{\text {escoamento }}^{2}
$$

Substituindo os valores de 3.28 e 3.29 em 3.27, obtém-se:

$$
\varphi=3 / 2 \frac{\varepsilon_{\text {eq }}}{\sigma_{\text {escoamento }}}
$$

Os valores de $s_{i j}$ e $\sigma_{i j}^{\prime}$ são intercambiáveis. 


\subsubsection{Relaçరes Experimentais de Tensర్s versus Deformaçర్s:} LUDWICK, hOLLOMAN, VOCE, SWIFT, RAMBERG-OSGOOD e de PRAGER

A tentativa de obter-se uma țeoria geral e: unificada da plasticidade dos metais, sempre esteve limitada às dificuldades encontradas na formulação e conștrução de relações experimentais entre as tensões e deformações.

No trabalho a quente, ou seja, para temperaturas acima das necessárias para a existência do fenômeno da recristalização, os mapas dos mecanismos de deformações, introduzidos por $\mathrm{ASHBY}^{7} \mathrm{e}$ generalizados por MILLER e LANGDON ${ }^{20}$, mostram que a busca de expressões gerais é de extrema dificuldade, exigindo um tratamento do tipo caso a caso.

No trabalho a frio, entretanto, apesar de complexas, existe a disponibilidade de várias expressões e cada uma delas descrevendo casos especificos de deformações.

LUDWICK ${ }^{22}$ propôs em 1909, uma expressão de ajuste de curvas a dados experimentais, constituida de dois parâmetros:

$$
\sigma=\sigma_{0}+H \varepsilon^{n}
$$

para:

$\sigma_{0}$ : tensão limite de referência

H: parâmetro constante de encruamento

$\mathrm{n}$ : indice de encruamento

A expressão de $\operatorname{LUDWICK}^{22}$ ajusta curvas a dados experimentais de metais trabalhado a frio.

Se se tiver $\sigma_{0} \simeq 0$, na relação de LUDWICK transforma-se na relação de HOLLOMON, ${ }^{23}$ conhecida como lei da potência e 
utilizada na fórmula parabólica de dois parámetros:

$$
\sigma=K \varepsilon^{n}
$$

sendo:

K: coeficiente de resistência plástica

$n$ : expoente de encruamento e é tal que, na condição de carga máxima $n$ tem o valor da deformação uniforme.

Apesar da complexidade algébrica, $\mathrm{VOCE}^{24} \mathrm{em} 1948$, propôs a fórmula de três parâmetros para metais, apresentando elevada ductilidade a frio:

$$
\sigma=a+(b-a)\{1-\exp (-n \varepsilon)\}
$$

nesta fórmula, $a, b$ e $n$ são parâmetros ajustáveis aos dados experimentais por meio de regressão não-linear, na atualidade.

SWIFT $^{25}$, em 1952, propôs uma fórmula ideal para metais e ligas, apresentando média ductilidade, cerca de $15 \mathrm{a} 40 \%$ de redução de área, na forma de:

$$
\sigma=c(a+\varepsilon)^{n}
$$

é, também, uma fórmula de três parâmetros.

No caso géral de comportamento elasto-plástico, a relação proposta por RAMBERG e OSGOOD ${ }^{26}$, em 1943, é de grande utilidade na prática da engenharia:

$$
\varepsilon=(\sigma / E)+K\left(\frac{\sigma}{E}\right)^{P}
$$

podendo a mesma ser normalizada pela relação: $\sigma_{0}=E \varepsilon_{0}$ da lei de HOOKE. ${ }^{27} \mathrm{~K}$ e $\mathrm{p}$ são parâmetros de ajuste.

A relação proposta por $\operatorname{PRAGER}^{28}$, em 1938, é 
freqüentemente utilizada na análise elasto-plástica. de materiais isotrópicos:

$$
\sigma=\sigma_{0} \tanh \left(\frac{E \varepsilon}{\sigma_{0}}\right)
$$

onde:

$\sigma_{0}$ é a tensão limite de escoamento

Nessa expressão de PRAGER, a deformação é definida no intervalo

$$
\cdots \quad-\infty \leq \varepsilon \leq \infty \text {. }
$$

\subsubsection{A Questao da Anisotropia na Plasticidade}

- critério de escoamento plástico para os metais e suas ligas é de fundamental importância no trabalho a frio. E a fórmula generalizada de HUBER-VON MISES e HENCKY ${ }^{29}$ é a mais adequada para a incorporação do efeito da anisotropia nos processos de confirmação plástica e é função, apenas, do segundo invariante das tensões reduzidas.

A forma do critério de escoamento plástico de TRESCA, apresenta cantos na superficie de escoamento, qué poderão ser removidos pela introdução do terceiro invariante do tensor das tensões reduzidas porém, apresenta uma grande dificuldade na introduçāo do efeito de anisotropia.

$\mathrm{HILL}^{30}$ introduziu a forma mais geral para o critério de escoamento plástico de HUBER-VON MISES e HENCKY, válida para um material ortotrópico, como sendo:

$$
\begin{aligned}
& \left\{\mathrm{F}\left(\sigma_{22}-\sigma_{33}\right)^{2}+\mathrm{G}\left(\sigma_{33}-\sigma_{11}\right)^{2}+\mathrm{H}\left(\sigma_{11}-\sigma_{22}\right)^{2}+\right. \\
& \left.\quad+2 \mathrm{~L} \sigma_{23}^{2}+2 \mathrm{M} \sigma_{13}^{2}+2 \mathrm{~N} \sigma_{12}^{2}\right\} \equiv \sigma_{\text {eq }}^{2}
\end{aligned}
$$


A forma mais geral possivel, foi dada por $\mathrm{HILL}^{31} \mathrm{em}$ 1979, para possibilitar o estudo do efeito da anisotropia em agregados metálicos, mas em função das tensões principais e obedecendo o critério de escoamento plástico de VON MISES:

$$
\begin{gathered}
\mathrm{F}\left|\sigma_{2}-\sigma_{3}\right|^{\mathrm{m}}+\mathrm{G}\left|\sigma_{3}-\sigma_{1}\right|^{\mathrm{m}}+\mathrm{H}\left|\sigma_{1}-\sigma_{2}\right|^{\mathrm{m}}+\mathrm{A}\left|2 \sigma_{1}-\sigma_{2}-\sigma_{3}\right|^{\mathrm{m}}+ \\
+\mathrm{B}\left|2 \sigma_{2}-\sigma_{3}-\sigma_{1}\right|^{\mathrm{m}}+\mathrm{C}\left|2 \sigma_{3}-\sigma_{1}-\sigma_{3}\right|^{\mathrm{m}}=\sigma_{\text {eq. }}^{\mathrm{m}}
\end{gathered}
$$

A equação 3.38 se reduz à 3.37 , quando:

$$
\ldots \quad m=2
$$

e ainda:

F for substituído por $F+2(B+C)-A$.

Para um material isotrópico, a relação de HUBER-VON MISES-HENCKY é dada por:

$$
1 / 2 \sigma_{i j}^{\prime} \sigma_{1 j}^{\prime}=\frac{1}{2} s_{1 j} s_{1 j}=k^{2}=\sigma_{0} 2 / 3
$$

E, de acordo com PRAGER ${ }^{32}$, o critério de TRESCA, na forma da superficie de escoamento é, em termos das tensões principais, da forma: .

$$
\left[\left(\sigma_{22}-\sigma_{33}\right)^{2}-4 \mathrm{~K}^{2}\right]\left[\left(\sigma_{33}-\sigma_{11}\right)^{2}-4 \mathrm{~K}^{2}\right]\left[\left(\sigma_{11}-\sigma_{22}\right)^{2}-4 \mathrm{~K}\right]^{2}=0 \quad 3.39 \mathrm{~b}
$$

e expressa o critério de TRESCA, em função da tensão de cisalhamento máxima, sem considerar o efeito da anisotropia para o 
escoamento plástico - equação 3.39 Também pode ser expresso em função do segundo e do terceiro invariantes do tensor das tensões reduzidas:

$$
4 J_{2}^{3}-27 J_{3}^{2}-36 K^{2} J_{2}^{2}+96 K^{4} J_{2}-64 K^{6}=0
$$

Os invariantes podem 'ser substituidos em função das tensões reduzidas principais:

$$
\begin{aligned}
& J_{1}=\sigma_{k k}^{\prime}=0 \\
& J_{2}=\frac{1}{2} \sigma_{k k}^{\prime 2} \\
& J_{3}=\frac{1}{3} \quad \sigma_{k k}^{\prime 3}
\end{aligned}
$$

3.2. Teoria Geral da Plasticidade na Conformação Plástica dos Metais

\subsubsection{Sistemas de Coordenadas Generalizadas: Sistemas de LAGRANGE e EULER, Tensós de CAUCHY, LAGRANGe e KIRCCHOF}

a) Sistemas de coordenadas Generalizadas

sāo descritos matematicamente por modelos tais que seus pontos geométricos coincidam com as suas particulas materiais. Quando um corpo sólido sofre mudança em sua configuração por ação de um agente físico externo, as continuidades materiais e geométricas requerem que pontos inicialmente vizinhos, assim permaneçam após a tranśŏormação, a menos que surjam descontinuidades, devido ao surgimento de fraturas ou trincas no sólido. 
Seja o sistema coordenado $\left(x_{1} x_{2} x_{3}\right)$, tal que um ponto $A$ do corpo, em um determinado instante de tempo evolutivo $t$ seja descrito pelas coordenadas $x_{1}$. Em um instante posterior $t+\Delta t, 0$ ponto A deforma para a posição $A^{\prime}$, com coordenadas $x_{1}$ no novo sistema $\left(x_{1} x_{2} x_{3}\right)$, figura 3.1 .

os sistemas coordenados $\left(x_{1} x_{2} x_{3}\right)$ e $\left(x_{1} x_{2} x_{3}\right)$ são curvilineos e descrevem um espaço Euclidiano.

A transformação da mudança de configuração na figura 3.1, dos pontos $A B C D$ para a figura $A^{\prime} B^{\prime} C^{\prime} D^{\prime}$, é realizada pelo mapeamento dado pelas expressões apresentadas por $\mathrm{FUNG}^{32}$, na forma:

$$
x_{1}=x_{1}\left(x_{1}, x_{2}, x_{3}\right)
$$

e sua respectiva transformação inversa:

$$
x_{1}=x_{1}\left(x_{1}, x_{2}, x_{3}\right)
$$

sendo as funções $x_{1}$ e $x_{1}$ são contínuas e diferenciáveis.

Um elemento de linha, infinitesimal, conectando o ponto $A\left(x_{1} x_{2} x_{3}\right)$ e ponto $B\left(x_{1}+d x_{1}, x_{2}+d \dot{x}_{2}, x_{3}+d x_{3}\right)$, sendo $A B$ de comprimento dș, na configuração original .é expressa matematicamente por:

$$
d s=g^{1} d_{1} d x_{1}
$$

$g^{11}$ : são os componentes do tensor métrico Euclidiano no sistema coordenado $\mathrm{x}_{1}$. 


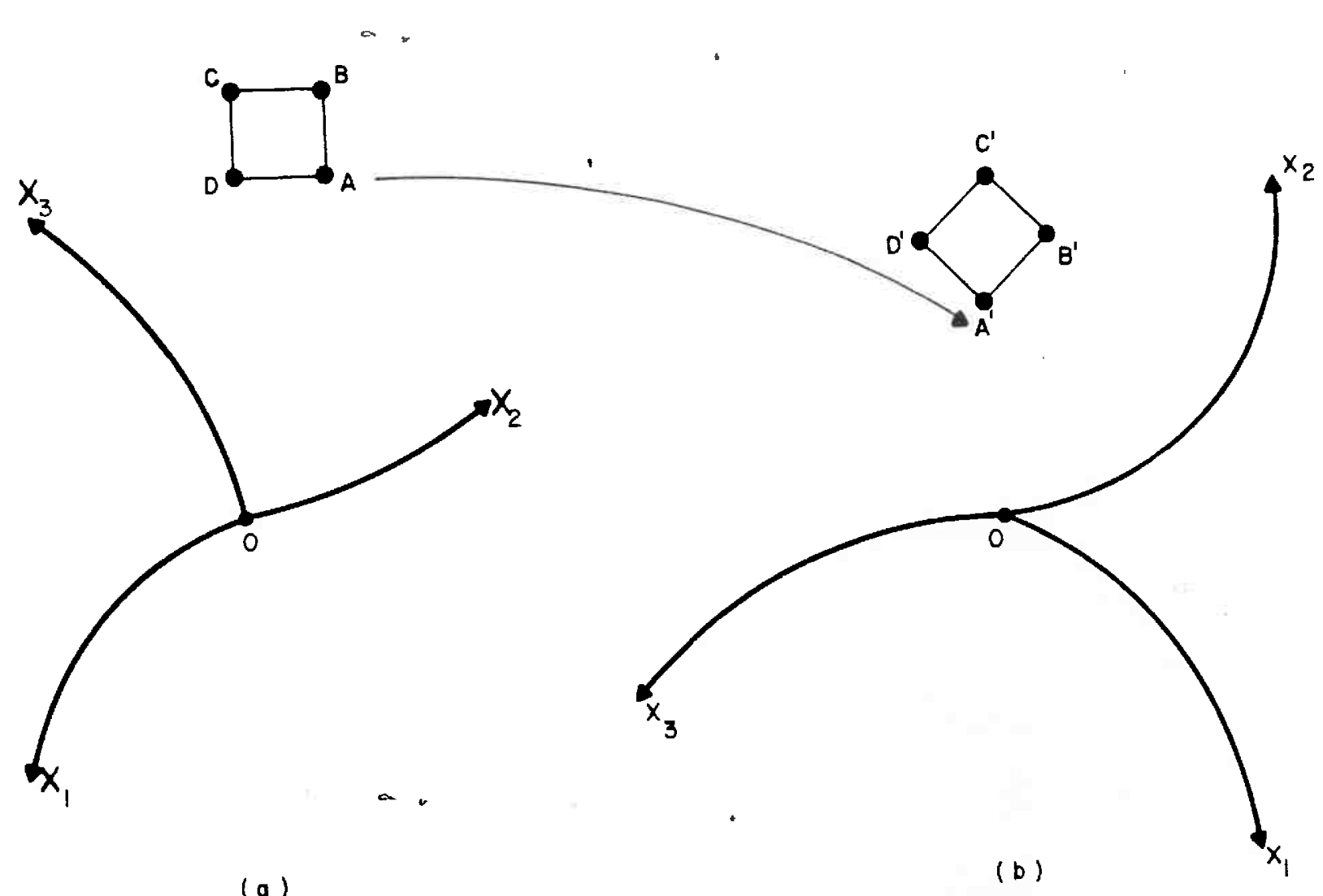

(a)

Figura 3.1. - Deformação de um corpo em função de suas coordenadas generalizadas curvilineas:

(a) sistema $\left(x_{1} x_{2} x_{3}\right)$, representando estado inicial

(b) sistema $\left(x_{1} x_{2} x_{3}\right)$, representando estado final 
Os pontos $A$ e $B$ deformam-se para os pontos $A^{\prime}\left(x_{1}, x_{2}, x_{3}\right)$ e $B\left(x_{1}+d x_{1}, x_{2}+d x_{2}, x_{3}+d x_{3}\right)$, formando uma linha $A^{\prime} B^{\prime}$ de comprimento ds, expressa na forma:

$$
d s=g_{1} d x_{1} d x_{j}
$$

onde, $g_{1}$, é tensor métrico Euclidiano no sistema $x_{1}$.

As transformações 3.45 e 3.46 formam os seguintes quadrados de comprimertos:

$$
d s^{2}=g^{11} \frac{\partial x_{1}}{\partial x_{1}} \quad \frac{\partial x_{j}}{\partial x_{m}} d x_{1} d x_{m}
$$

e

$$
d s^{2}=g_{1} \frac{\partial x_{1}}{\partial x_{1}} \frac{\partial x_{j}}{\partial x_{m}} d x_{1} d x_{m}
$$

A diferença entre os quadrados de comprimento, após uma mudança de indices, são da forma:

$$
\begin{gathered}
d s^{2}-d s^{2_{\alpha}}=\left(g_{\alpha \beta} \frac{\partial x_{\alpha}}{\partial x_{1}} \frac{\partial x_{\beta}}{\partial x_{j}} \cdot g^{1 j}\right) d x_{1} d x_{j} \\
d s^{2}-d s^{2}=\left(g_{1 j}-g^{\alpha \beta} \frac{\partial x_{\alpha}}{\partial x_{1}} \frac{\partial x_{\beta}}{\partial x_{j}}\right) d x_{1} d x_{j}
\end{gathered}
$$

Em analogia à hidrodinâmica, define-se os seguintes tensores de deformações finitas: 
a) Componentes do tensor de deformação de GREEN nas coordenadas materiais de LAGRANGE, denominados componentes do tensor de deformação de GREEN-LAGRANGE:

$$
{ }_{\varepsilon_{1 j}}=\frac{1}{2}\left(g_{\alpha \beta} \frac{\partial x_{\alpha}}{\partial X_{1}} \frac{\partial x_{\beta}}{\partial X_{j}}-g^{1 j}\right) \text { : }
$$

b) Componentes do tensor de deformação de AIMANSI, em coordenadas geométricas de EULER, ou denominados de componentes de deformação de ALMANSI-EULER:

$$
{ }^{E_{\varepsilon}},-\approx \frac{1}{2}\left(g_{1,}-g^{\alpha \beta} \frac{\partial x_{\alpha}}{\partial x_{i}} \frac{\partial x_{\beta}}{\partial x_{j}}\right) \text {. }
$$

Os tensores ${ }^{E} \varepsilon_{1 j}$ e ${ }^{L_{\varepsilon}} \varepsilon_{1 j}$ são simétricos, provados por verificação direta que:

$$
E_{1 j}=E^{E} \varepsilon_{j 1}
$$

e

$$
\varepsilon_{1 j}={ }^{L} \varepsilon_{j 1}
$$

No caso de deformação infinitesimal, o tensor de deformação de ALMANSI-EULER, transforma-se no tensor de deformação de CAUCHY.

o sistema coordenado $\left(\mathrm{x}_{1} \mathrm{x}_{2} \mathrm{x}_{3}\right)$ é utilizado para descrever posições das partículas em qualquer instante $t+\Delta t$, baseado na configuração original. Já o sistema coordenado $\left(x_{1} x_{2} x_{3}\right)$ é utilizado para descrever posiçōes das partículas em um instante $t+\Delta t$ da configuração deformada.

No caso de sistemas coordenados retangulares, existem duas escolhas: 
ou

$$
g_{1 j}=g^{11}=\delta_{1 j}
$$

$$
{ }^{L} \varepsilon_{1,}=E_{\varepsilon_{11}}=\frac{1}{2}\left(g_{11}-g^{11}\right)
$$

Na primeira escolha, a equação 3.55 , o uso do mesmo sistema de coordenadas retangulares pode ser utilizado para descrever, tanto situações nas configurações original ou deformada.

$\mathrm{Na}$ segunda escolha, a equação 3.56 , o sistema de referência retangular fica distorcido na configuração deformada, de tal modo que as coordenadas das partículas nos sistemas $x_{i} e x_{i}$, possuam os mesmos valores numéricos.

Neste trabalko, optar-se-á pela escolna dada pela equação 3.55 , onde:

$$
g_{1 j}=g^{i j}=\delta_{1 j}=\left\{\begin{array}{l}
1, \text { se } i=j \\
0, \text { se } i \neq j
\end{array}:\right.
$$

o vetor deslocamento uapresenta seus componentes na

forma:

$$
u_{1}=x_{1}-x_{1}
$$

c) Tensores de Tensão e Deformação

Define-se os componentes físicos do tensor de tensão $\tau^{1 j}$, como sendo os componentes do vetor de tensão \pm resolvidos nas direções dos vetores unitários, paralelos aos vetores-base de um sistema ortogonal de coordenadas, na forma:

$$
\sigma_{1 j}=\sqrt{\frac{g_{j j}}{g^{11}}} \tau_{i j}
$$


onde $i \sigma_{1 j}$ são os componentes físicos de $\tau_{1\}}$

Quando $I$ for resolvido no vetor recíproco, os componentes físicos são da forma:

$$
\cdots \sigma_{j}^{1}=\sqrt{\frac{g^{j J}}{g_{11}}} \tau_{j}^{1}
$$

Os componentes da deformação física são da forma:

$$
\varepsilon_{i j}={\frac{1}{{\sqrt{g_{11}}}^{g_{j j}}}}^{E \varepsilon_{i j}}
$$

Nos sistemas curvilineos:

$$
\begin{gathered}
g_{1 j}=g^{11}=0, \text { se } i \neq j \\
11 g^{11}=(g)^{-1}
\end{gathered}
$$

Para o sistema de coordenadas generalizadas, em sistema curvilineo ortogonal, os componentes físicos tensoriais são:

$$
\begin{aligned}
& \sigma_{i j}=\sqrt{g_{11}} \sqrt{g_{j j}} \tau_{1 j} \\
& \sigma_{j}^{1}=\sqrt{g^{j j}} \sqrt{g_{11}} \sigma_{j}^{1} \\
& \varepsilon_{1 j}=\sqrt{g^{11}} \sqrt{g^{j j}} E_{\varepsilon_{1 j}}
\end{aligned}
$$

São essas expressões: $3.62,3.63$ e 3.64 que permitem escrever as equações de equilibrio de forças, relações de tensōes versus deformações, as condições de compatibilidade em qualquer 
sistema coordenado, e são tambemprincipalmente importantes na conformação plástica de metais, porque a mesma envolve grandes deformações.

ZYCZKOWSKI 21 e FUNG $^{32}$ apresentam os resultados das transformações para os sistemas em coordenadas cilindricas e esféricas. VIASOV ${ }^{32}$ em 1944, deduziu as transformações para as equações de compatibifidade.

Para um sólido contínuo em estado deformado, sem considerar-se as transformações' de coordenadas, as equações de equilibrio para os componentes físicos de tensões, são da forma:

$$
\frac{\partial \sigma_{13}}{\partial x_{j}}+b_{j}
$$

Um tensor de tensão no estado deformado é: um conceito físico natural, mas os componentes do tensor de tensão estão relacionados aos componentes do tensor de deformação. Se as deformações se referirem ao estado original das posições das particulas, então é necessário definir as tensões também no estado original.

No estado original, tem-se as trações relacionadas à regra de LAGRANGE, enquanto que no estado deformado a de KIRCHHOFF .

A condição de IAGRANGE, figura 3.2 , leva à definição da transformação, na forma:

$$
\text { d } \quad \mathrm{L}_{\mathrm{T}_{1}}=\mathrm{dT} \mathrm{T}_{\mathrm{i}}
$$

A condição de KIRCHHOFF, na mesma figura 3.2 , define a trasnformação na forma:

$$
d{ }^{k} x_{1}=\frac{\partial x_{1}}{\partial x_{j}} d T_{j}
$$


em similaridade à transformação:

$$
d x_{1}=\frac{\partial x_{1}}{\partial x_{j}} d x_{J}
$$

A relação de CAUCHY, com os respectivos componentes das tensões no estado deformado, denotando um vetor força $d T_{1}$, $e$ atuando numa superficie elementar ds, cujo vetor unitário tenha componentes $v_{j}$ é da forma:

$$
d T_{1}=\sigma_{1,}, d s
$$




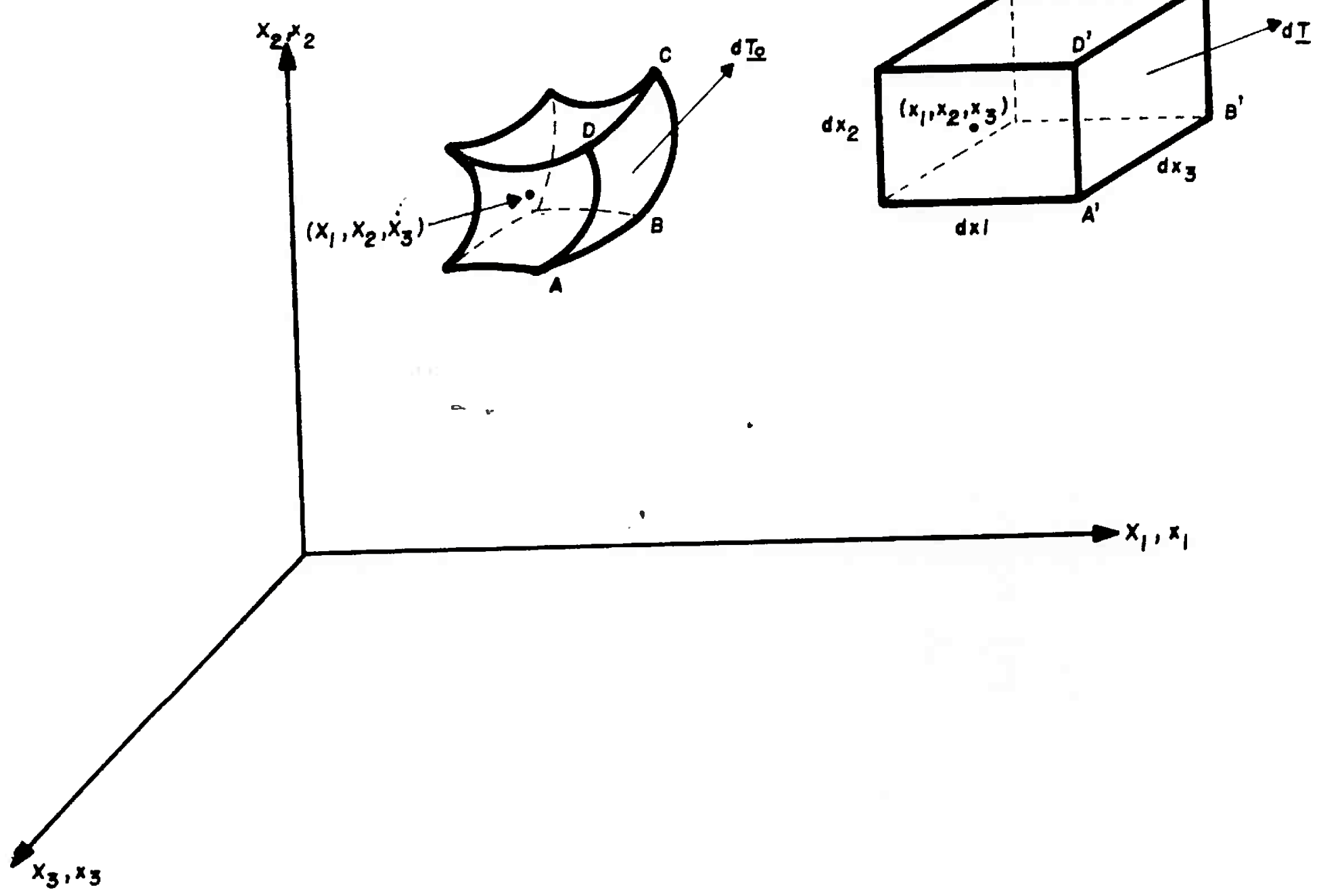

Figura 3.2. - Incrementos de traçãọ nos estados original e deformado. 
A transformação de LAGRANGE forma-se, então, do seguinte modo:

$$
\text { d } \quad \mathrm{L}_{\mathrm{T}_{1}}=\mathrm{T}_{1,} \nu_{0}, \mathrm{dS} \mathrm{S}_{0}=\mathrm{dT} \mathrm{T}_{1}
$$

Já a transformação de KIRCHHOFF, é do tipo:

$$
\mathrm{d} \quad \mathbf{x}_{\mathrm{T}_{1}}=\mathrm{s}_{1,}, \nu_{0} \text {, dSo }=\frac{\partial \mathrm{x}_{1}}{\partial \mathrm{x}_{\alpha}} \mathrm{d} \mathrm{T}_{\alpha}
$$

sendo:

$\sigma_{11}$ : componentes do tensor de tensão de CAUCHY

$T_{11}$ : componentes do tensor de tensão de LAGRANGE

$s_{1 j}$ : componentes do tensor de tensão de KIRCHHOF

$\sigma_{1 j}$ : componentes do tensor de tensão deEULER

Se $\rho_{0}$ e $\rho$ são as densidades materiais nas configuraçōes original e deformada, então:

$$
\begin{gathered}
\mathrm{T}_{j 1}=\frac{\rho_{\rho}}{\rho} \frac{\partial \mathrm{X}_{j}}{\partial \mathrm{x}_{\mathrm{j}}} \sigma_{\text {mi }} \\
\mathrm{S}_{1 j}=\frac{\rho_{\mathrm{o}}}{\rho} \frac{\partial \mathrm{X}_{1}}{\partial \mathrm{x}_{\alpha}} \frac{\partial \mathrm{X}_{\mathrm{j}}}{\partial \mathrm{x}_{\beta}} \sigma_{\beta \alpha}
\end{gathered}
$$

Os tensores de EULEn e de KIRCHHOFF são simétricos, mas ○ de LAGRANGE não o é.

Até aqui, percebe-se que o grande problema e o esforço feito foi e o é de esclarecer que o tensor de tensão de LAGRANGE é, de acordo com FUNG $^{32}$, inconveniente para se utilizar na conformação plástica dos metais envolvendo deformações finitas. 
Neste caso é comum o uso do denominado segundo tensor de tensão de PIOLA-KIRCHHOFF : $s_{11}$

As relações entre os componentes tensoriais $S_{1 j}$ e $T_{1 j}$,

são:

$$
S_{\jmath 1}=\frac{\partial X_{1}}{\partial x_{\alpha}} \quad T_{j \alpha}
$$

A utilização da identidade:

$$
s_{1 j}=\frac{\partial x_{1}}{\partial x_{p}} \quad \frac{\partial x_{p}}{\partial x_{j}}
$$

tem-se:

$$
\sigma_{j 1}=\frac{\rho}{\rho_{0}} \frac{\partial \mathrm{x}_{1}}{\partial \mathrm{X}_{\mathrm{p}}} \mathrm{T}_{\mathrm{pj}}=\frac{\rho}{\rho_{0}} \frac{\partial \mathrm{x}_{1}}{\partial \mathrm{X}_{\alpha}} \frac{\partial \mathrm{x}_{\mathrm{j}}}{\partial \mathrm{X}_{\beta}} \mathrm{S}_{\beta \alpha}
$$

sendo que:

$$
T_{i j}=\frac{\partial x_{j}}{\partial X_{p}} S_{i p}
$$

As equações de equilibrio, em função das tensões Lagrangeanas, são:

$$
\ldots \quad \frac{\partial T_{1 j}}{\partial X_{j}}+\rho_{0} b_{1}=0
$$

que, em termos das tensões de KIṚCHHOFF, ficam na forma:

$$
\frac{\partial}{\partial X_{j}}\left[S_{j k}\left(\delta_{i k}+\frac{\partial u_{1}}{\partial X_{k}}\right)\right]+\rho_{0} b_{o_{1}}=0
$$

As expressões apresentadas, de 3.45 a 3.79 , são as que 
permitem o tratamento de qualquer problema, por metodos, tais como: os variacionais e os dos Elementos Finitos.

\subsubsection{Sistemas de Equaçชes para Problemas de Conformaçăo}

\section{Plástica dos Metais}

- sistema de equações a ser resolvido, dentro da teoria da plasticidade, consiste, no caso mais geral, em um sistema com dezesseis equações. Dessas, nove equações - das quais três são de equilibrio e seis de relações de deformações versus deslocamentos - são comuns a todos os ramos da mecânica dos sólidos contínuos.

As equações de equilíbrio são, para a forma cartesiana, do tipo:

$$
\sigma_{1, j, j}+b_{j}=0
$$

onde:

$b_{j}$ : componentes de for̂ças de campo.

As seis equaçōes, relacionando deformaçōes com deslocamentos, formam-se para' as deformações finitas de GREEN-LAGRANGE, do seguinte modo:

$$
\mathrm{L}_{\varepsilon_{1 j}}=\frac{1}{2}\left(\mathrm{U}_{1, j}+\mathrm{U}_{j, 1}+\mathrm{U}_{\mathrm{k}, 1} \cdot \mathrm{U}_{\mathrm{k}, j}\right)
$$

e para as deformações de EULER-ALMANSI, como:

$$
E_{\varepsilon_{i j}}=\frac{1}{2}\left(u_{i, j}+u_{j, i}-u_{k, i} u_{k, j}\right)
$$

$\mathrm{Na}$ forma infinitesimal, as relaçōes 3.81 e 3.82 tornam-se, respectivamente: 


$$
\mathrm{L}_{1,} \propto \frac{1}{2}\left(\mathrm{U}_{1, j}+\mathrm{U}_{j, 1}\right)
$$

e

$$
E_{1,} \propto \frac{1}{2}\left(u_{1,1}+u_{1,1}\right)
$$

Os componentes do tensor de deformação de EULER-ALMANSI tornam-se, na forma infinitesimal, nos componentes tensoriais da CAUCHY.

As equações 3.83 e 3.84 , quańdo expressas nas formas de taxas de deformações, dão origem, às seguintes equações, em termos de derivadas materiais:

$$
\mathrm{d}^{\mathrm{L}} \varepsilon_{1,}=\frac{1}{2}\left(\mathrm{~d} u_{k, 1}+\mathrm{d} u_{1, k}\right) x_{k, 1} x_{1, j}
$$

e

$$
d^{E} \varepsilon_{1 j}=\frac{1}{2}\left(d u_{i, j}+d u_{j, 1}\right)-{ }^{E} \varepsilon_{i k} d u_{k, j}+{ }^{E} \varepsilon_{j 1} \quad d u_{1,1} \quad 3.86
$$

No caso uniaxial, as correspondentes deformaçōes são da forma geral:

$$
{ }^{(n)} \varepsilon_{x}=\frac{1}{n}\left[1-\left(\frac{\ell_{0}}{\ell_{1}}\right)^{n}\right]
$$

sendo que para cada valor de $n$, temos as seguintes cońvençōes:

$\mathrm{n}=-1$ : deformação convencional

$\mathrm{n}=-2$ : deformação de LAGRANGE

$\mathrm{n}=+2$ : deformação de EULER

Se $n$ tender para o infinito, as deformaçōes são as conhecidas deformações logaritmicas ou de HENCKY . 
No caso de pequenas deformações, referenciadas aos componentes diagonais, zYCZKowsKI ${ }^{21}$, mostra que existe a seguinte relação entre as deformaçōes de HENCKY, EULER e IAGRANGE:

$$
{ }^{\mathrm{H}} \varepsilon_{1}=\frac{1}{2} \ln \left(1+2^{\mathrm{L}} \varepsilon_{1}\right)=-\frac{1}{2} \ln \left(1-2^{E_{\varepsilon_{1}}}\right)
$$

As equações de 3.81 a 3.88 poderão ser., substituídas pelas seis equações de compatibilidades de SAINT-VENANT, existentes entre as deförmações e os deslocamentos:

$$
\varepsilon_{1, k 1}+\varepsilon_{k l, 1\}}-\varepsilon_{1 k, j 1,}-\varepsilon_{j 1,1 k}=0
$$

que descrevem, dessa forma, oitenta e uma equações, ' ' quando na realidade necessitamos apenas de seis.

Uma forma mais compacta de descrever as condições de SAINT-VENANT das compatibilidades, é expressá-las apenas com dois indices livres:

$$
e_{1 \mathrm{~km}} e_{j 1 \mathrm{n}} \varepsilon_{\mathrm{kl}, \mathrm{mn}}=0
$$

$e_{1 j k}$ é o simbolo permutador alternante, e possui os seguintes valores:

$e_{i j k}=0$, para quaisquèr dois indices entre $i, j, k$ iguais

$e_{i j k}=1$, se $i, j, k$ são permutaçōes pares de $x_{1}, x_{2}$ e $x_{3}$

$e_{1 j k}=-1$, se $i, j, k$ são permutaçōés ímpares de $x_{1}, x_{2} e \cdot x_{3}$

No caso de coordenadas generalizadas, as equações de compatibilidades foram desenvolvidas por VLASOV ${ }^{33}$.

A equação da variação de volume da teoria da elasticidade:

$$
\varepsilon_{k k}=\frac{(1-2 v)}{E} \sigma_{k k}
$$


constitui-se na décima equação da téoria da plasticidade e a mesma, de acordo com os trabalhos de BRIDGMAN, discutidos em NADAI $^{34}$, é invariante dentro de uma faixa ampla de pressão hidrostática, utilizada na conformação plástica dos metais.

As diferenças entre as equações da plasticidade e da elasticidade repousam nas cinco leis de variações de formas, relacionando tensões e deformações, que, na plasticidade, introduzem novas funções desconhecidas $\varphi$ e $d \lambda$, formando as seguintes teorias de deformações plásticas:

a) teoria do escoamento plástico incremental de LEVY-VON MISES:

$$
d \varepsilon_{1 j}^{p}=d \lambda \sigma_{1 j}^{\prime}
$$

b) teoria do escoamento plástico incremental de PRANDTL-REUSS:

$$
\mathrm{d} \varepsilon_{i j}=\frac{1}{2 G} \mathrm{~d} \sigma_{1 j}^{\prime}+\mathrm{d} \lambda \sigma_{1 j}^{\prime}
$$

c) teoria da deformação plástica de HENCKY

$$
\varepsilon_{i j}=\varphi \sigma_{1 j}^{\prime}
$$

As equações $3.92,3.93$ e 3.94 , dão cinco equaçõesque juntamente com um dos dois critérios de escoamento plástico o de HUBER-VON MISES- HENNCKY ou o de TRESCA fornecem as dezesseis equações mencionadas anteriormente.

Das dezesseis equações aprésentadas, apenas as de equilíbrio e as das relações versus deslocamentos são passiveis de mudanças para outros sistemas de coordenadas, pela utilização da métrica Euclidiana do cálculo tensorial, enquanto que para as equações 
remanescentes, em um sistema localmente ortogonal, é suficiente a mudança formal dos indices.

As condições de contórno na superficie $s$, determinam três componentes de tensões, formando o vetor de i carga para a condição de contorno natural numa superfície $S_{T}$ de $S$, e três componentes de deslocamentos ou velocidades impostas no contorno $S_{u}$ de $s$, conhecida como condiçāo de contorno geométrico.

No caso de se ter um problema elasto-plástico, pode-se determinar na zona plastificada, onde $\mathrm{d} \lambda>0$ ou $\varphi>\frac{1}{2 \mathrm{G}}$, todas as dezesseis variáveis desconhecidas. Já, na zona .elástica, onde $\varphi=\frac{1}{2 \mathrm{G}}$ ou $\mathrm{d} \lambda=0$, 0 número de variáveis desconhecidas se resume a quinze.

Devido ao grande número de incógnitas e equações, é importante o estudo dos métodos de redução daś equações e variáveis, de modo que se possa aplicar métodos anaíticos para a busca de soluções dos problemas de conformação plástica. Tais técnicas de redução de equações e variáveis são de importância fundamental nas aplicações dos métodos numéricos.

As expressões para os vários sistemas de coordenadas ortogonais, são da forma seguinte; após conșideração da transformação:

$$
x_{1}=x_{1}+u_{1}
$$

que mapeia a localização de uma particula no ponto $x_{1}$ de um espaço tridimensional, para um ponto $x_{1}$ no mesmo espaço.

os componentes do tensor de deformação infịitesimal, em relação ao sistema $x_{1}$ : 


$$
\epsilon_{11}=\frac{1}{2}\left[\frac{\partial u_{1}}{\partial x_{1}}+\frac{\partial u_{j}}{\partial x_{1}}\right]
$$

Já para deformação infinitesimal, o tensor é, em relação a $x_{1}$ :

$$
\epsilon_{1 j}=\frac{1}{2}\left[\frac{\partial u_{1}}{\partial x_{j}}+\frac{\partial u_{j}}{\partial x_{1}}\right]
$$

mas para deformações finitas, em relação a $x_{1}$, tem-sè o tensor de deformação de GREEN-LAGRANGE:

$$
L_{\varepsilon_{1 j}}=\frac{1}{2}\left[\frac{\partial u_{i}}{\partial x_{j}}+\frac{\partial u_{j}}{\partial x_{1}}+\frac{\partial u_{k}}{\partial x_{1}} \frac{\partial u_{k:}}{\partial x_{j} .}\right]
$$

e para as deformações finitas, em relação ao sistema $x_{1}$, o tensor de deformação é o de ALMANSI-EULER:

$$
E_{\varepsilon_{1 j}}=\frac{1}{2}\left[\frac{\partial u_{1}}{\partial x_{j}}+\frac{\partial u_{j}}{\partial x_{i}}-\frac{\partial u_{k}}{\partial x_{i}} \frac{\partial u_{k}}{\partial x_{j}}\right]
$$

A equação de equilíbrio, em relação ao conceito físico natural é:

$$
\frac{\partial \sigma_{1 j}}{\partial x_{j}}+b_{1}=0
$$

onde os tensores de tensão natural $\sigma_{11}$ e 0 de KIRCHHOFF $S_{11}$, estão relacionados, de forma tal que:

$$
\left.s_{j 1}=\rho_{0} / \rho\left[\sigma_{j 1}-\int_{j \beta} \frac{\partial u_{1}}{\partial x_{\alpha}}+\delta_{1 \alpha} \frac{\partial u_{j}}{\partial x_{\beta}}-\frac{\partial u_{1}}{\partial x_{\alpha}} \frac{\partial u_{j}}{\partial x_{\beta}}\right) \sigma_{\alpha \beta}\right]
$$


e

$$
\sigma_{j 1}=\rho_{0} / \rho\left[s_{j 1}+\left(\delta_{j \beta} \frac{\partial u_{1}}{\partial x_{\alpha}}+\delta_{1 \alpha} \frac{\partial u_{j}}{\partial x_{\beta}}+\frac{\partial u_{1}}{\partial x} \frac{\partial u_{j}}{\alpha x}\right)_{\beta} s_{\beta \beta}\right]
$$

3.101

Já as equações de equilíbrio em termos dos componentes do tensor não-simétrico de .IAGRANGE, é:

$$
\frac{\partial T_{j 1}}{\partial x_{j}}+\rho_{0} b_{o_{1}}=0
$$

e a equação de equilíbrio, em termos dos componentes do tensor simétrico de KIRCHHOFF é, tal que:

$$
\frac{\partial}{\partial X_{j}}\left[S_{j k}\left(\delta_{i k}+\frac{\partial u_{1}}{\partial X_{k}}\right)\right]+\rho_{0} b_{0_{1}}=0^{\prime}
$$

Em termos de coordenadas curvilíneas ortogonais, é possível a obtenção das equações apreséntadas de 3.94 a 3.103 , se for realizada a seguinte identificação para os componentes do tensor métrico Euclidiano para pequenas deformações:

a) Coordenadas cilindricas em termos fisicos: $\epsilon_{1 \mathrm{j}}$ e $\sigma_{1, j}$

$$
\begin{gathered}
x_{1}=r ; x_{2}=\theta \text { e } x_{3}=z \\
d s^{2}=d r^{2}+r^{2} d \theta^{2}+d z^{2} \\
g_{11}=1 ; g_{22}=r^{2} ; g_{33}=1 ; \operatorname{outros} g_{1 j}=0
\end{gathered}
$$




$$
\begin{gathered}
g^{11}=1 ; g^{22}=\frac{1}{r^{2}} ; g^{33}=1 ; \text { outros } g^{1 j}=0 \\
=- \\
\Gamma_{22}^{1}=-r ; \Gamma_{12}^{2}=\Gamma_{21}^{2}=\frac{1}{r} ; \text { outros } \Gamma_{j k}^{1}=0
\end{gathered}
$$

como:

$$
\epsilon_{1 j}=\sqrt{g^{11}} \sqrt{g^{1 j}} e_{1 j}
$$

então, obtem-se:

$$
\begin{aligned}
& \epsilon_{r r}=\frac{\partial u_{r}}{\partial r} \\
& \epsilon_{\theta \theta}=\frac{1}{r} \frac{\partial u_{\theta}}{\partial \theta}+\frac{u_{r}}{r} \\
& \epsilon_{\mathrm{zz}}=\frac{\partial \mathrm{u}_{\mathrm{z}}}{\partial \mathrm{z}} \\
& \epsilon_{\theta z}=\frac{1}{2}\left(\frac{\partial u_{\theta}}{\partial z}+\frac{l^{\prime}}{r} \frac{\partial u_{r}}{\partial \theta}\right) \\
& \epsilon_{z r}=\frac{1}{2}\left(\frac{\partial u_{z}}{\partial r}+\frac{\partial u_{r}}{\partial z}\right) \\
& \epsilon_{r \Theta}=1 / 2\left(\frac{1}{r} \frac{\partial u_{r}}{\partial \theta}+\frac{\partial u_{\theta}}{\partial r}-\frac{u_{\theta}}{r}:\right)
\end{aligned}
$$

As equações de equilibrio em coordenadas cilindricas,

são:

$$
\begin{gathered}
\frac{\partial \sigma_{r r}}{\partial r}+\frac{1}{r} \frac{\partial \sigma_{\Theta r}}{\partial \theta}+\frac{\partial \sigma_{z r}}{\partial z}+\frac{\sigma_{r r}-\sigma_{\Theta \Theta}}{r}+b_{r}=0 \\
\frac{\partial \sigma_{r \Theta}}{\partial r}+\frac{1}{r} \frac{\partial \sigma_{\theta \Theta}}{\partial \theta}+\frac{\partial \sigma_{z \Theta}}{\partial z}+\frac{2 \sigma_{r \Theta}}{r}+b_{\Theta}=0
\end{gathered}
$$




$$
\frac{\partial \sigma_{r z}}{\partial r}+\frac{1}{r} \frac{\partial \sigma_{\theta z}}{\partial \theta}+\frac{\partial \sigma_{z z}}{\partial z}+\frac{\sigma_{r z}}{r}+b_{z}=0 \quad 3.106 c
$$

b) Coordenadas esféricas em termos físicos:

$$
\begin{gathered}
\varkappa_{1}=r ; x_{2}=\phi ; x_{3}=\theta \\
d s^{2}=d r^{2}+r^{2} d \phi^{2}+r^{2} \operatorname{sen}^{2} \phi d \theta^{2}
\end{gathered}
$$

então:

$$
\begin{gathered}
g_{11}=1 ; g_{22}=r^{2} ; g_{33}=r^{2} \operatorname{sen}^{2} \phi ; \text { outros } g_{1 j}=0 \\
g^{11}=1 ; g^{22}=\frac{1}{r^{2}} ; g^{33}=\frac{1}{r^{2} \operatorname{sen}^{2} \emptyset} ; \text { outros } g^{11}=0 \\
\Gamma_{22}^{1}=-r ; \Gamma_{33}^{1}=-r \operatorname{sen}^{2} \phi ; \\
\Gamma_{12}^{2}=\Gamma_{21}^{2}=\frac{1}{r} ; \Gamma_{33}^{2}=-\operatorname{sen} \phi \cos \phi: \\
\Gamma_{13}^{3}=\Gamma_{31}^{3}=\frac{1}{r} ; \Gamma_{23}^{3}=\Gamma_{32}^{3}=\cot \phi ; \text { outros } \Gamma_{\alpha k}^{\sigma}=0
\end{gathered}
$$

A forma mais geral para as equações das relações deformações versus deslocamentos édo seguinte tipo para pequenas deformaçōes:

$$
{ }^{E} \varepsilon_{1 j}=\frac{1}{2}\left(u_{1, j}+u_{j, 1}\right)-\Gamma_{1 j}^{\sigma} u_{\sigma}
$$

- uso de expressões válidas para pequenas deformações, permite a aplicação direta das relações de taxas de deformações $d \varepsilon_{11}$, nas relações paramétricas de velocidades, do tipo:

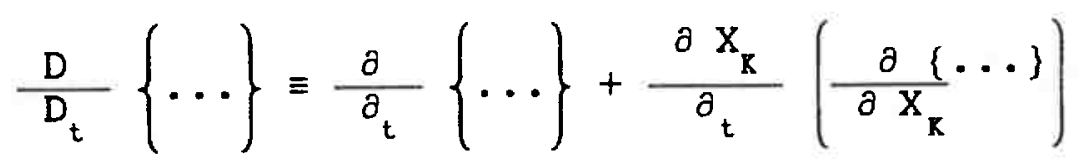

que é na realidade uma derivada material, em termos de coordenadas espaciais, que é generlcamente expressa, por: 


$$
\frac{D}{D_{t}}\{\ldots\}=\frac{\partial}{\partial_{t}}\{\ldots\}
$$

Os incrementos ou taxas de deformações de GREEN-LAGRANGE e de ALMANSI-EULER, ficam expressos nas formas seguintes:

$$
{ }_{\dot{\varepsilon}_{1 j}}=\frac{d}{d_{t}}{ }^{L} \varepsilon_{1 j}=\frac{D^{L} \varepsilon_{1 j}}{D_{t}}=\frac{\partial^{L} \varepsilon_{1 j}}{\partial_{t}}
$$

e

$$
E_{\dot{\varepsilon}_{11}}=\frac{d}{d_{t}}{ }_{\varepsilon_{\varepsilon}}=\frac{D}{D_{t}} \quad E_{\varepsilon_{1 j}}=\frac{\partial^{E_{\varepsilon_{1 j}}}}{\partial_{t}}+\frac{\partial^{E_{\varepsilon_{1 j}}}}{\partial \mathrm{X}_{K}} \frac{\partial \mathrm{X}_{k}}{\partial_{t}}
$$

\subsection{Métodos de Resoluçסes de Problemas Elasto-Plásticos}

A dependência da história do processo de cọnformação é originada pela natureza dissipativa de energia na plasticidade dos metais.

Vários métodos analiticos e semi-analitịcos têm sido propostos para a análise de problemas de conformação plástica como é apresentado em BRESCIANI FILHO ${ }^{35}$. Os vários métodos apresentam vantagens e desvantagens de acordo com a análise dos mesmos realizada por THOMSEN $^{36}$ e colaboradores.

Neste trabalho, a preocupação é com a utilização de um método que seja o mais" geral possivel, e seja tambem capaz de conter, em sua formulação, os mais variados fenômenos possiveis de serem observáveis na conformaçãó plástica . o método deve ainda considerar os efeitos oriundos das condições de contorno e das solicitaçōes externas no processo.

o desafio é também construir, através do método a ser escolhido, um critério de conformação através da'mecânica da fratura não-linear. 


\subsection{Método Variacional na Elasticidade e na Plasticidade}

- método variacional é,segundo alguns pesquisadores, 0 mais atualizado para a análise de problemas em suas formulações matemáticas em HILDEBRAND ${ }^{37}$; na mecânica dos meios contínuos de acordo com SOKOLNIKOFF ${ }^{39}$; na análise de tensões e de deformações por métodos energéticos segundo $\operatorname{RICHARD}^{38}$; e na'aplicação do método dos elementos finitos por ZIENKIEWICCZ ${ }^{40}$.

- método consiste na determinação de um vetor-função $u_{i}\left(r_{j}\right)$ desconhecido, de classe $c^{1}$, satisfazendo um sistema de equaçōes diferenciais parciais dentro de um domínio do espaço e as respectivas condições de contorno impostas pelo problema . Essa função é tal que, quando o vetor-função e suas respectivas derivadas forem substituidas, numa relação integral volumétrica limitada por uma superficie,forma-se uma relação funcional, cuja respectiva variação da origem a uma condição estacionária para o problema. Nessas condições, o vetor-função será um ex̣tremo para o problema.

A aplicação do princípio do trabalho virtual é a formulação fraca do problema variacional e surge da.transformação do problema de seresolver um sistema de equações diferenciais parciais para uma formulação integral, de modo que o vetor-função do deslocamento virtual de uma classe, que exige a. continuidade das derivadas parciais de ordem $n$, passa a ser um vetor-função da classe de continuidade de ordem $n-1$.

A prova do princípio de trabalho virtual, na sua forma mais geral, é apresentada em ZIENKIEWICs ${ }^{4}$, para os casos que envolvam materiais elásticos lineares e nãợineares. As formulações mais elegantes estão nas provas realizadas por LoVE ${ }^{41}$, 
RICHARDS $^{38}$ e SOLKONIKOFF ${ }^{39}$. o, princípio variacional e sua respectiva generalização, introduzido por HILL ${ }^{13}$ em 1948, para aplicaçōes na plasticidade dos metais será objeto de estudo neste trabalho.

\subsubsection{Teoremas Gerais da Formulação Variacional}

seja o problema definido na região de dominio $V$, limitada pela superficie de contorno $s$, como mostra a figura 3.3 . A equação:

$$
\sigma_{1,1}+f_{1}=0
$$

é satisfeita em $V$, bem como a condição de contorno:

$$
t_{1} \doteq \sigma_{11} n_{j}
$$

é satisfeita na superficie $\mathrm{S}$.

onde:

$\sigma_{1 j}$ : é o tensor de tensão

$f_{1}$ : é o vetor força de campo por unidade de volume

$n_{j}$ : é o vetor unitário normal à superfície

A formulação fraca é introduzida através de um vetor-função deslocamento arbitrário virtual $\delta u_{1} e$ é dada pela definição de trabalho virtual:

$$
\int_{\text {volume }} \delta u_{1}\left(\sigma_{1, j, j}+f_{1}\right) d V=0 .
$$

A equação 3.114 fornece, após integração por partes, pela utilização do teorema integral de GREEN, de acordo com WYLIE ${ }^{43}$, a seguinte formulação: 


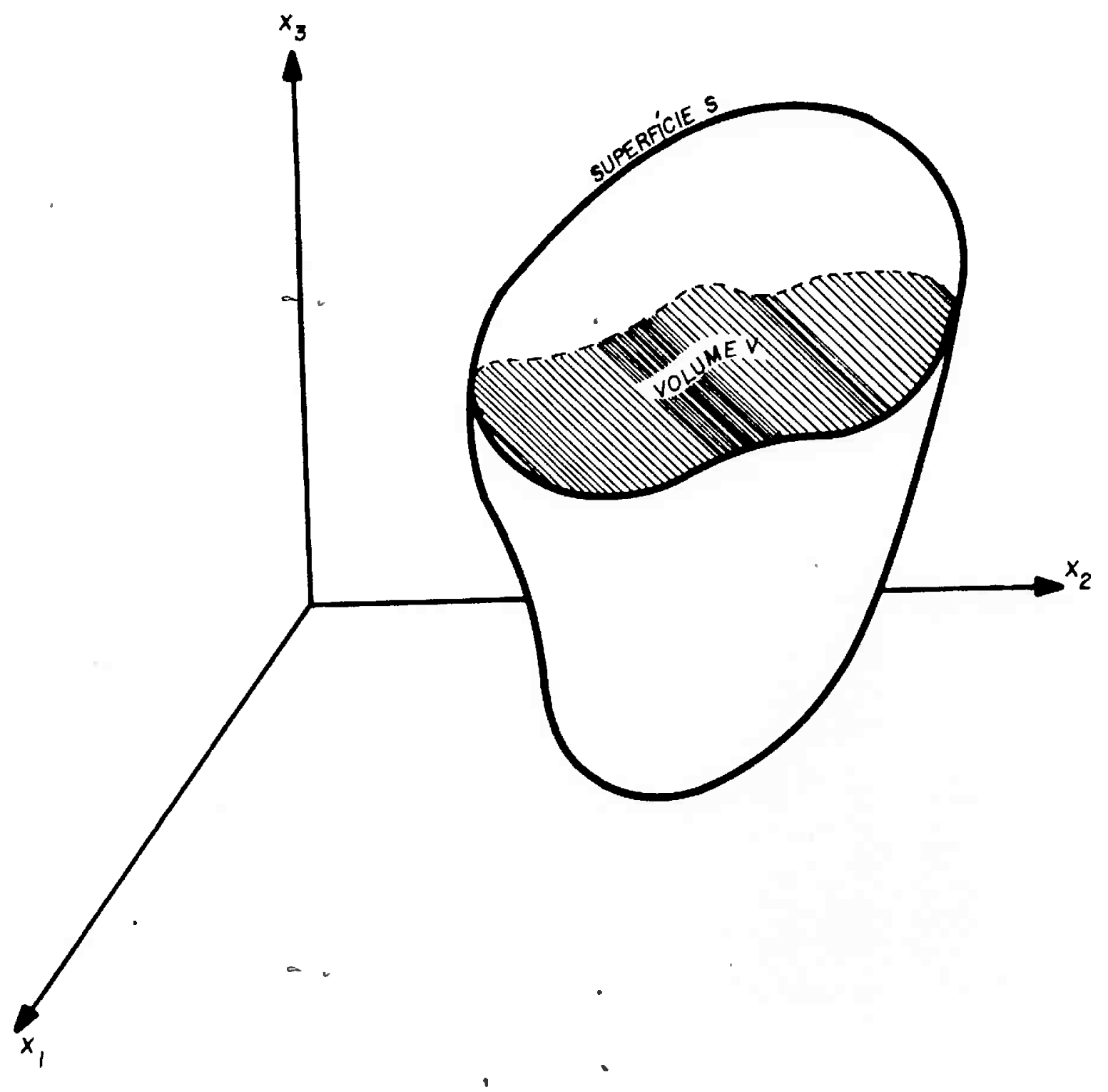

Figura 3.3. - Problema a ser resolvido pelo método variacional num volume V, limitado pelo contorno da superficie S. 
$\int_{v o l}\left(\sigma_{1,} \delta u_{1, j}-\delta u_{1} f_{1}\right) d v+\int_{\text {area }} \delta u_{1} \sigma_{1,} n_{j} d s=0 \quad 3.115$

No primeiro termo em 3.115 , o fator $\delta u_{1, j}$ representa 0 tensor de deformação virtual. Já o segundo termo $\sigma_{1, j}$, é o vetor de tensão $t_{1}$.

A equação 3.115 , na sua forma compacta, é representada por:

$$
\int_{\text {vol }} \sigma_{1 j} \delta \varepsilon_{1 j} d V-\int_{v o l} f_{1} \delta u_{1} d V-\int_{\text {Sarea }} t_{1} \delta u_{1} d S=0
$$

A resolução da equação integral 3.116 , pelo método variacional, consiste na utilização de métodos diretos, como os de RAYLEIGH-RITZ, de KANTOROVITCH ou de GALERKIN, todos descritos em RICHARDS $^{38}$. Já um método indireto é o dos Elementos Finitos, em ZIENKIEWICZ ${ }^{110}$.

o método de RAYLEIGH-RITZ, consiste em substituir na equação integral 3.116 , a função tentativa:

$$
u_{1}\left(\dot{x}_{1}, x_{2}, x_{3}\right)=\sum_{k=1}^{n} c_{t k} \cdot \phi_{k}\left(x_{1}, x_{2}, x_{3}\right)
$$

onde $n$ : é a n-ésima aproximação

As funções $\dot{\psi}_{k}\left(x_{1}, x_{2}, x_{3}\right)$ devem satisfazer as condições de contornos especificadas pelo problema. A minimização da integral funcional 3.116, fornece um sistema de equações lionearesa ser solucionado pela determinação dos coeficientes $C_{1 k}$. 
- método de KANTOTOVITCH consiste na separação das funções, de tal modo que:

$$
u_{1}\left(x_{1}, x_{2}, x_{3}\right)=\sum_{k=0}^{n} \psi_{k}\left(x_{1}\right) \phi_{k}\left(x_{2}\right) x_{k}\left(x_{3}\right)
$$

e para quaisquer duas funções, satisfazendo as condições de contorno, a terceira função será determinada pela resolução da equação de EULER-LAGRANGE, através do método variacionnal. 37,38

- método de GALERKIN é o' da resolução da equação diferencial parcial, pela expansão em série de uma função tentativa:

$$
u_{1}\left(x_{1}, x_{2}, x_{3}\right)=\sum_{k=1}^{\infty} C_{k} \phi_{k}\left(x_{1}, x_{2}, x_{3}\right)
$$

onde as funções $\phi_{k}\left(x_{1}, x_{2}, x_{3}\right)$ devem satisfazer as condições de ortogonalidades para a determinação das constantes $c_{k}$ :

Já o método indireto dos elementos finitos é um procedimento numérico para a solução de problemas estruturais e de problemas da mecânica dos meios contínuos, dentro de um determinado grau de precisão especificado. Consiste $\circ$ mesmo em resolver o funcional da formulação integral, equação 3.115 , dentro de uma malha de elementos finitos, através de funções tentativas de configuração do deslocamento de pontos nodais em "cada elemento, de modo que haja continuidades das deformações. É um método apropriado a trabalhos com geometrias complexas, $\operatorname{coor}^{44}$.

Um sistema é uma estrutura do meio continuo sólido e os respectivos carregamentos agindo sobre o mesmo. Uị sistema é considerado conservativo se quando o mesmo for deslocado de uma 
para outra configuração, ao retornar a situação prévia, as forças que agem sobre o mesmo realizam trabalho nulo, para qualquer que seja o caminho percorrido pela trajetória de carga.

Um campo de deslocamento é admissível se ... mesmo não violar as condições internas de compatibilidade ou as condições forçadas de solicitaçōes impostas ao sistema.

Agora, é conveniente definir o conceito do principio da energia potencial mínima, $\operatorname{coOK}^{44}$ :

Entre todas as configurações possiveis de um sistema conservativo, aquelas `que satisfizerem, as equações de equilibrio do sistema, fazem a energia potencial estacionária em relação às pequenas variações de deslocamentos. Se a condição estacionária for um mínimo, então o equilíbrio do sistema será estável.

\subsubsection{Método de HILl do Trabalho Plástico}

Se o principio variacional de trabalho plástico, introduzido simultaneamente por $\mathrm{MARKOV}^{45} \mathrm{e} \mathrm{HILL}^{30}$, for válido para um material, que obedeça o critério de escoamento de HUBER-VON MISES-HENCKY, satisfaça as relações entre tensões e deformaçōes de PRANDTL-REUSS ou de LEVY-VON MISES, na forma válida para o sistema $\sigma_{1 j}$, para asaseguintes condições:

a) as condições de equilíbrio:

$$
\frac{\partial \sigma_{1 j}}{\partial x_{j}}+b_{1}=0
$$

b) o critério de HUBER-VON MISES-HENCKY

$$
\frac{1}{2} \sigma_{1 j}^{\prime} \sigma_{19}^{\prime}=\mathrm{K}^{2}
$$


c) as relações de LEVY-VON MISES

$$
\mathrm{d} \varepsilon_{1 j}^{\mathrm{p}}=\sigma_{1 j}^{\prime} \mathrm{d} \lambda
$$

Então, a taxa com que as forças superficiais agindo no sistema realizam trabalho trabalho, é maior que qualquer outra para um outro sistema de tensão $\sigma_{1 j}^{*}$, numa mesma velocilade de superficie, desde que $\sigma_{11}^{*}$ satisfaça as equaçōes de equilibrio e o critério de escoamento impostos.

HILL ${ }^{46}$ propôs, em 1963, um método geral pạa a análise de processo de conformação plástica dos metais cómbinando rigor matemático e flexibilidade, estabelecéndo que um bom método de aproximação deve ser capaz de reproduzir e prever os principais fenômenos envolvidos na análise, fornecer informações a respeito das cargas e solicitações mecânicas e ainda șẹ capaz de avaliar as principais variações dimensionais.

Na análise do método de HILI, é vantajoso estabelecer um vetor unitário normal e externo à superfície de contorno de um volume do metal, sob condição de estar escoando plásticamente.

Se os tensores forem representados como vetores auxiliares num espaço nono-dimensional, sendo ainda o potencial plástico definido por $g\left(\sigma_{1 j}\right)$, então os incrementos de deformações plásticas são dados pelo vetor incremental:

$$
\mathrm{d} \underline{\varepsilon^{p}}=\underline{\mathrm{n}}_{\mathrm{g}} \mathrm{d} \lambda
$$

De acordo com WYLIE ${ }^{43}$, o vetor ng unitário e normal à superfície potencial :

$$
g\left(\sigma_{1,}, K^{2}\right)=0
$$


é definido por:

$$
\underline{n}_{g}=\frac{\underline{\nabla}\left(\sigma_{1,}, k^{2}\right)}{\left|\underline{\nabla}\left(\sigma_{1 j}, k^{2}\right)\right|}=\frac{\frac{\partial g\left(\sigma_{1,}, k^{2}\right)}{\partial \sigma_{11}}}{\left|\frac{\partial g\left(\sigma_{k 1}, k^{2}\right)}{\partial \sigma_{k 1}}\right|}
$$

que na condição de plasticidade, associada fornece a condição:

$$
\underline{n}_{r} \equiv \underline{n}
$$

HILL propôs uma formulação similar ao do atual teorema do limite superior, como sendo um critério aproximado, mas baseado no procedimento de GALERKIN e KANTOROVICH do método variacional, na seguinte forma:

A condição suficiente para que uma considerada distribuição de tensões tenha propriedades estáticas que satisfaçam as equações de equilíbrio, dentro de um volume $v$, e também as condições de contornos impostas na superficie $S$, é que os divergientes tenham taxas líquidas de trabalho nulas na classe estabelecida pelo movimento virtual.

Na linguagem das funções especiais, isso quer dizer que os divergentes devem ser ortogonais aos movimentos virtuais.

A expressão para o enunciado de HILL é dada por:

$$
\int_{\text {Vol }} \sigma_{i j} \frac{\partial w_{j}}{\partial x_{i}} d V=\int_{s_{I}} \sigma_{j} w_{j} d S-P \int_{s_{F}} n_{j} w_{j} d S+: \gamma+\phi
$$


sendo o valor de $\boldsymbol{\gamma}$, dado por uma, das expressões seguintes:

$$
\gamma=\int s_{c}\left(\left(n_{1} \sigma_{1}\right) n_{j}+k_{1 j}\right\} w_{j} d s
$$

que representa a parcela do trabalho de atrito relacionada com a total aderência na interface material-matriz.

ou

$$
\gamma=\int_{s_{c}}\left(n_{1} \sigma_{1}\right)\left(n_{j}-\mu l_{j}\right) w_{j} d S
$$

representando a parcela do trabalho relacionada com a presença de atrito na interface material metálico-matriz.

e ainda tem-se:

$w_{j}$ : é o vetor velocidade ortogonalizante virtual

$\mu$ : coeficiente de atrito de coulumb

Vol: volume da zona de deformação

$\mathrm{S}_{\mathrm{I}}$ : superficie de junção das zonas elástica e plásticas

$S_{F}$ : superficie livre exposta à pressão hidrostática $\mathbf{p}$

$s_{C}$ : superficie de contato entre matriz e corpo deformante

$\phi$ é o termo correspondente à descontinuidade de uma superficie $\Sigma$. Nessa superficie de descontinuidade, o vetor tração $\tau$, é tangente à superficie e tem-se: .

$$
\left.\phi=\int \Sigma_{j}^{\prime} \tau_{j}\right] \mathrm{d} \Sigma
$$

sendo que $\left[w_{j}\right]$ é a componente tangencial de descontinuidade da velocidade virtual. 
o método de HILI' foi aplicado por LAHOTI e KOBAYASHI ${ }^{47}$ em problemas de conformação plástica, onde se obteve bons resultados, mas, quando comparado com outros métodos, percebeu-se melhoramentos.

\subsubsection{Método dos Limites de PRAGER}

- método dos limites, baseados nos ęnunciados de PRAGER $^{48}$, para análise dos valores extremos, tem sua formulação fundamentada nas conciições básicas, para a existência de descontinuidades no campo de velocidades. Essas condições básicas são as mesmas elaboradas por HILL $\mathrm{H}^{49}$ e KACHANOV ${ }^{50}$ na análise de problemas de plasticidade pelo método das linhas de deslizamentos para o caso do estado plano de tensão.

Para um material de LEVY-VON MISES, as partículas sobre uma parte da superficie do contorno $s_{v}$, que contém 'o volume $v$, movem com uma dada velocidade $v_{1}$, enquanto outra porção da superfície $S_{T}$ do contorno $S$ está sujeita aos vetores de tração $T_{1}$. Se o corpo inteiro estiver sob estado de escoamento plástico, é então o objetivo, determinar as componentes do tensor de tensão $\sigma_{1 j}$ e as taxas de deformação d $\varepsilon_{1 j}$.

Se $s_{v} \equiv s$, ou seja, envolver toda a superficie, então, as velocidades superficiais devem satisfazer as condịções globais de incompressibilidade, de modo que a integral de superficie dos componentes normais seja nula.

Se ao contrário for $S_{T}$ a superficie $S$, tal que $S_{T} \equiv S$, então os componentes dos vetores de tensão devem satisfazer as condições globais de equilibrio. 
Um campo de tensão $\sigma_{1 \jmath}^{a}$, definido no corpo de volume $V$ envolvido por uma superficie $S$, será denominado estaticamente admissivel se o mesmo satisfizer as condiçōes de equilibrio:

$$
\sigma_{11,1}=0
$$

um critério de escoamento plástico como:

$$
\sigma_{11}^{\prime} \sigma_{1 j},-2 k^{2}=0
$$

e as condiçōes de contorno sob่re $\mathrm{S}_{\mathrm{T}}$, do tipo : .

$$
\mathrm{T}_{1}=\sigma_{1,} \mathrm{n}_{1}
$$

Um campo de taxa de deformações $a \varepsilon_{i j}^{b}$ definido dentro de um corpo de volume $V$, envolvido por uma superficie $S$, será considerado cinematicamente admissivel, se $\circ$ mesmo, quando derivado de um campo de velocidade $v_{1}^{b}$, satisfaça: as condições de incompressibilidade:

$$
v_{1,1}^{b}=0
$$

em todo o volume $v, \ldots$

e ao mesmo tempo, as condições de velocidades na fronteira $\mathrm{s}_{\mathrm{v}}$.

Teorema 1: Entre todos os campos de tensão estaticamente admissiveis, o verdadeiro maximiza a expressão:

$$
I=\int s_{v} \sigma_{1 j}^{a} v_{1} n_{j} d s
$$


Teorema 2: Entre todos os campos de deformação cinematicamente admissiveis, o verdadeiro minimiza a expressão:

$$
J=\int v 2^{1 / 2} K\left[d \varepsilon_{1,}^{b} d \varepsilon_{1 j}^{b}\right]^{1 / 2} d V-\int S_{T} T_{1} v_{1}^{b} d S
$$

- principio dos valores extremos para um material, obedecendo as relações de PRANDTL-REUSS, segue as condições postuladas no caso de LEVY-VON MISES, com as condições adicionais seguintes :

$$
\sigma_{1,}^{\prime} \sigma_{1,}^{\prime}-2 \mathrm{~K}^{2}=0
$$

e

$$
\sigma_{1 j}^{\prime} \mathrm{d} \sigma_{1 j}^{\prime}=0
$$

As taxas de deformações dadas pela relação de PRANDTL-REUSS :

$$
d \varepsilon_{1 j}=\frac{1}{2 G} \sigma_{i j}^{\prime}+\frac{d \lambda^{\prime}}{2 G} \sigma_{i j}^{\prime}
$$

multiplicando 3.126 por $\sigma_{1 j}^{\prime}$, usando as condições 3.126 e 3.127 , temos:

$$
2 G \mathrm{~d} \varepsilon_{1 j}=\sigma_{1,}^{\prime} \mathrm{d} \sigma_{1 j}^{\prime}+\mathrm{d} \lambda^{\prime} \sigma_{1,}^{\prime} \sigma_{1 j}^{\prime}=2 \mathrm{~K}^{2} \mathrm{~d} \lambda^{\prime}
$$

$$
\mathrm{d} \lambda^{\prime}=0
$$

se $\sigma_{i j}^{\prime} \sigma_{i j}^{\prime}<2 k^{2}$ ou $\sigma_{1 j}^{\prime}$ d $\sigma_{1 j}^{\prime}=0$ 
e

$$
d \lambda !=\frac{G}{K^{2}} \sigma_{1 j}^{\prime} d \varepsilon_{1\}}
$$

se $\sigma_{1 j}^{\prime} \sigma_{1 j}^{\prime}=2 \mathrm{~K}^{2}$ ou $\sigma_{1 \mathrm{j}}^{\prime} \mathrm{d} \sigma_{1 \mathrm{j}}^{\prime}=0$

Como $d \lambda$ ' não pode ser negativo, então a equação seguinte deve ser satisfeita:

$$
d \lambda^{\prime}=\frac{G}{K^{2}} \sigma_{1 j}^{\prime} \quad d \varepsilon_{1 j}>0
$$

então:

$$
\sigma_{1\}} \mathrm{d} \varepsilon_{1 j}>0
$$

se ocorrer de $\sigma_{1 j}^{\prime} \sigma_{1 j}^{\prime}=2 K^{2}$ ou $\sigma_{i j}^{\prime} d \sigma_{1 j}^{\prime}=0$

As relações de PRANDTI-REUSS são finalmente da forma:

$$
d \sigma_{1 j}^{\prime}=2 G d \varepsilon_{1 j}
$$

se $\sigma_{i j}^{\prime} \sigma_{i j}^{\prime}<2 K^{2}$

ou

$$
\mathrm{d}_{i j}^{\prime}=\sigma_{i j}^{\prime}, \sigma_{1 j}^{\prime}=2 \mathrm{~K}^{2}
$$

e

$$
\sigma_{1 j}^{\prime} \mathrm{d} \varepsilon_{1 \mathrm{~J}} \leq 0
$$

ou

$$
d \sigma_{i j}^{\prime}=2 G\left(d \varepsilon_{1 j}-\frac{\sigma_{k 1}^{\prime} \varepsilon_{k 1}}{2 K^{2}} \sigma_{1 j}^{\prime}\right)
$$

se $\sigma_{i j}^{\prime} \sigma_{i j}^{\prime}=2 K^{2}$ e $\sigma_{i j}^{\prime} d \varepsilon_{i j}>0$ 
Agora, o campo dâs"taxas de tensões $d \sigma_{1 \jmath}^{c}$, definido em todo o volume do corpo, será estaticamente admissível se ocorrer simultaneamente o equilibrio em todo o volume $\mathrm{V}$ :

$$
\mathrm{d} \sigma_{1,1,1}^{c}=0
$$

se a restrição for satisfeita:

$$
\sigma_{i j}^{\prime} \mathrm{d} \sigma_{i j}^{\prime} \leq 0 ; \text { para } \sigma_{1 j}^{\prime} \sigma_{1 j}^{\prime}=2 K^{2}
$$

e se as condições de contorno sobre $S_{T}$ for:

$$
\mathrm{d} \sigma_{1,}^{c} \mathrm{n}_{3}=\mathrm{dT}_{1} ; \text { sobre } \mathrm{s}_{\mathrm{T}}
$$

- campo das taxas de deformações $d \varepsilon_{1 J^{\prime}}^{d}$ será cinematicamente admissivel se for derivado de um campo de velocidade $v_{1}^{d}$, que satisfaça as condições de incompressibilidade:

$$
\mathrm{v}_{1,1}^{\mathrm{d}}=0
$$

e, simultaneamente, as condiçōes de velocidades no contorno $\mathrm{S}_{\mathrm{v}}$. Nas condições estabelecidas para a teoria de PRANDTL-REUSS, tem-se os teoremas seguintes:

Teorema 3: Entre os corpos de tensões estaticamente admissiveis, $\quad$ verdadeiro minimiza a expressão: 


$$
K^{c}=\frac{1}{4 G} \int_{V}^{a} d \sigma_{1,}^{c} d \sigma_{1,}^{\prime} d V=\int_{S} d \sigma_{11}^{c} v_{1} n_{1} d s \quad 3.131
$$

Teorema 4: Entre todos os campos de taxas de deformações admissiveis, o verdadeiro minimiza a expressão:

$$
L^{d}=\frac{1}{2} \int_{V} d \sigma_{1,}^{d} d \varepsilon_{1,} d V-\int_{S} d T v_{1}^{d} d S
$$

3.4.4. Aplicaçð̋es dos Teoremas dos Valores Extremos na Conformação Plástica dos Metais

TARNOVSKY ${ }^{52}$ a colaboradores, e KUDO ${ }^{52-55}$ foram os primeiros pesquisadores a aplicarem os teoremas dos limites na plasticidade dos metais.

Uma forma de solução de problemas pela aplicação do teorema do limite superior, numa forma expandida, foi, a realizada por AVITZUR ${ }^{56}$ e simultaneamente por KOBAYASHI ${ }^{57,58}$ que estudaram os problemas de axissimetrias pelo limite superior. AVITZUR $^{59}$ apresentou soluções para vários tipos de problemas de conformação plástica, através da utilização do método expandido, que consiste em adotar um campo de velocidade possivel satisfazendo a constância de volume $e$ as condiçōes de velocidades na superficie do corpo $e$, ao mesmo tempo, as tensões devem satisfazer o critério de HUBER-VON MISES-HENCKY e as condições de atrito nas interfaces para as componentes tangenciais do vetor de tensão aplicado.

- problema fundamental da presença de descontinuidade nos campos das velocidades cinematicamente admissiyeis é o que 
permitirá a introdução de um critério de conformabilidade baseado na mecânica da fratura não-linear elasto-plástica.

se um corpo deformado plasticamente for dividido em várias zonas de deformação plástica, como mostra a figura 3.4 , segundo a proposta de AVITZUR ${ }^{59}$, os respectivos vetores de velocidades $v_{1}$ e $v_{2}$ não serão idênticos, mas a condição de constância de volume exige que suas componentes normais o sejam, então:

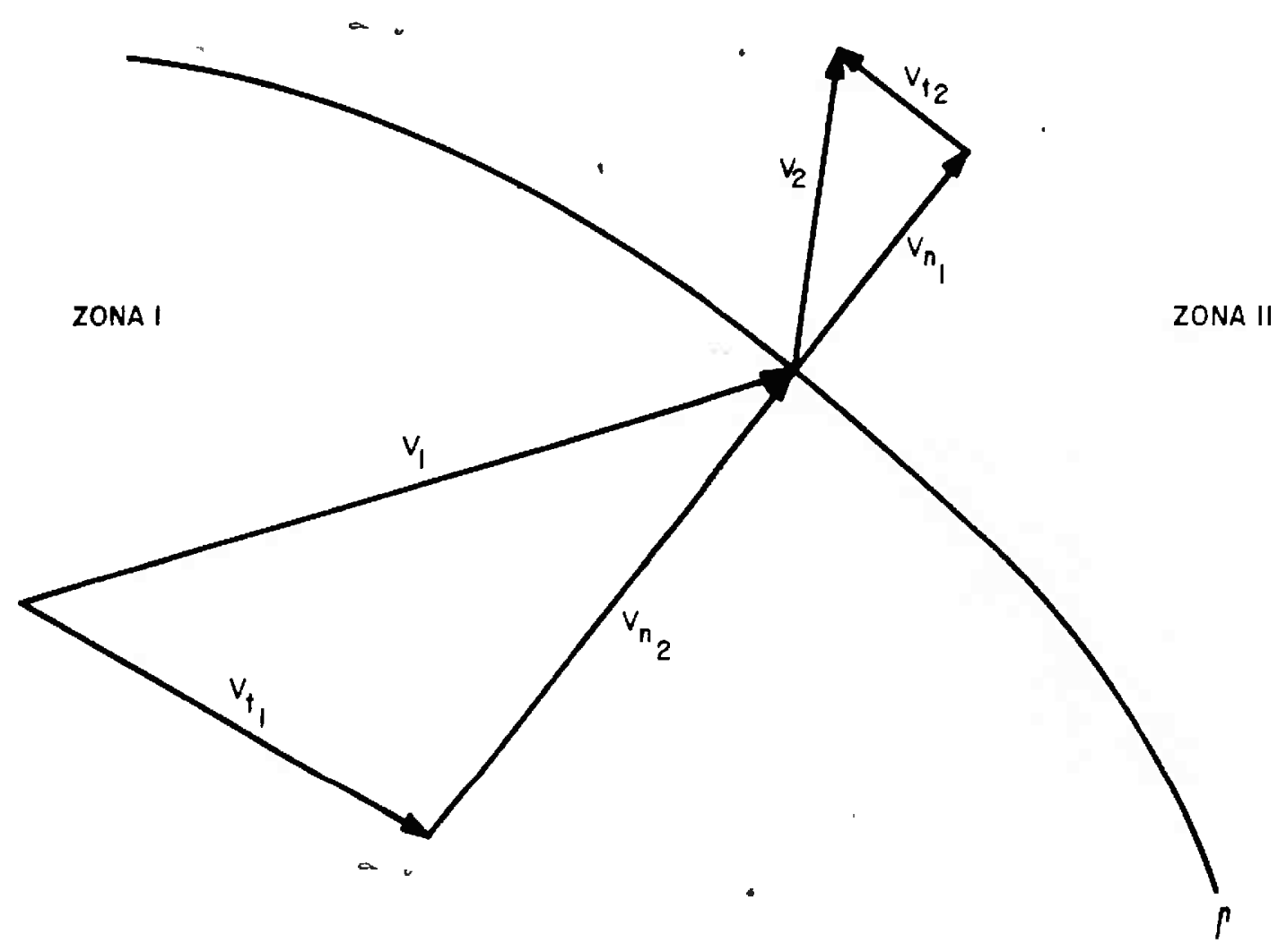

Figura 3.4. Fronteiras de descontinuidades no: campo de velocidades. 
As componentes tangenciais são, então, admitidas serem descontinuas na interface entre as zonas $I$ e II, de modo a satisfazer a inequação vetorial e permitir a deformação plástica no interior do corpo por movimentação relativa entre as superfícies em contato:

$$
\mathrm{v}_{1} \neq \mathrm{v}_{2}
$$

que de acordo com as condiçōes admissíveis, requer que a seguinte condição exista:

$$
\Delta v=v_{t_{1}}-v_{t_{2}}
$$

Se ocorrer de se ter na expressão $3.133 a$, a condição:

$$
v_{n_{1}} \neq v_{n_{2}}
$$

ocorre então uma violação da constância de volume imposta pela mecânica dos meios continuos e neste caso existe uma liberação de energia para a formação de superfície livre no interior do corpo sólido ou o surgimento de uma trinca.

A utilização da taxa de energia liberada pelo uso da mecânica da fratura não-linear, através de integrais invariantes, recompõe a parcela de energia perdida na formulação do método do limite superior.

Essas integrais invariantes serão, então, incorporadas nas formulações variacionais para os estudos de conformabilidade plástica dos metais. 
3.5. Mecânica da Interaçăo entre Superficies en Contato na Conformaçăo Plástica: fenomeno do atrito

- problema que ainda permanece insolúvel na busca dos verdadeiros campos de tensões e de deformações é a obtenção de um campo genérico de velocidades verdadeiras.

HILL $^{46}$ propôs que os possiveis campos seriam os ortogonalizáveis, por outro lado AVITZUR ${ }^{59}$ propôs ' os chamados campos genéricos expanáiveis através de um método proposto por $\mathrm{KUDO}^{52}$.

A formulação do atrito nas interfaces é dada pela imposição de descontinuidades nas componentes tangenciais de velocidades, e a parcela de potência perdida na formulação do limite superior é suprida pela expressão:

$$
\frac{d}{d t} \underset{\text { Interface }}{w_{s}}=\int_{s} \tau|\Delta v| d s
$$

onde:

$$
\frac{d}{d t} W_{s} \text { : é a potência de cisalhamento dissipada }
$$

e

$$
|\Delta v|=\left|\begin{array}{l}
v_{\text {tangencial }}^{\text {da ferramenta }} \\
\text { do metal }
\end{array}\right|
$$

Dois modelos de atritos serão considerados; o primeiro, apesar de já compreendido por LEONARDO DA VINCI, tece seu enunciado em bases físicas, formulado por AMONTONS ${ }^{62}$, e teve uma contribuição importante de COULOMB $^{61}$ que separou o atrito dinâmico do atrito estático, não especificando entretantọ os seus mecanismos. 
A lei de AMONTONS-COULOMB do atrito se anuncia, como:

$$
\tau=\mu \mathrm{p}
$$

sendo:

$\tau$ : tensão de atrito operando nas interfaces entre duas superficies em contato, cuja ação da força correspondente obedece a terceira lei de Newton.

p : pressão ou componente normal do vetor de tração atuando nas interfaces.

$\mu$ : é o coeficiente de atrito de couLOMb.

Essa lei de CoUlomb é válida para baixos valores de pressão, obedecendo às respostas elásticas das camadas próximas às superfícies das interfaces, cuja avaliação macroscópica se dá pela aproximação dos meios contínuos. A figura 3.5 mostra os mecanismos atuantes, segundo AVITZUR ${ }^{62}$.

Na lei de AMONTONS-COULOMB, o coeficiente de atrito é considerado, por simplicidade, independente da pressão, mas é função da natúreza das superficies de contato, do tipo de lubrificante existente entre as superficies e é inflítenciado pela temperatura das superficies. A dificuldade existente na determinação experimental do coeficiente $\mu$, para uso na conformação plástica, pode ser removida pela aplicação do ensaio do anel, proposto por MALE e COCKROFT $^{63}$, cuja análise do ensaio foi realizada por métodos numéricos através dos estudos de LEE e $\operatorname{ALTAN}^{64}$.

A questão dos lubrificantes, que influenciam de modo significativo as condições de atritos nos processos de conformação, têm sido objeto de intensivo estudo por scHEY ${ }^{65}$; 
assim como o estudo do efeito das camadas de revestimentos na estampagem de chapas recebeu contribuição dos dos trabalhos de BRESCIANI FILHO ${ }^{66}$.

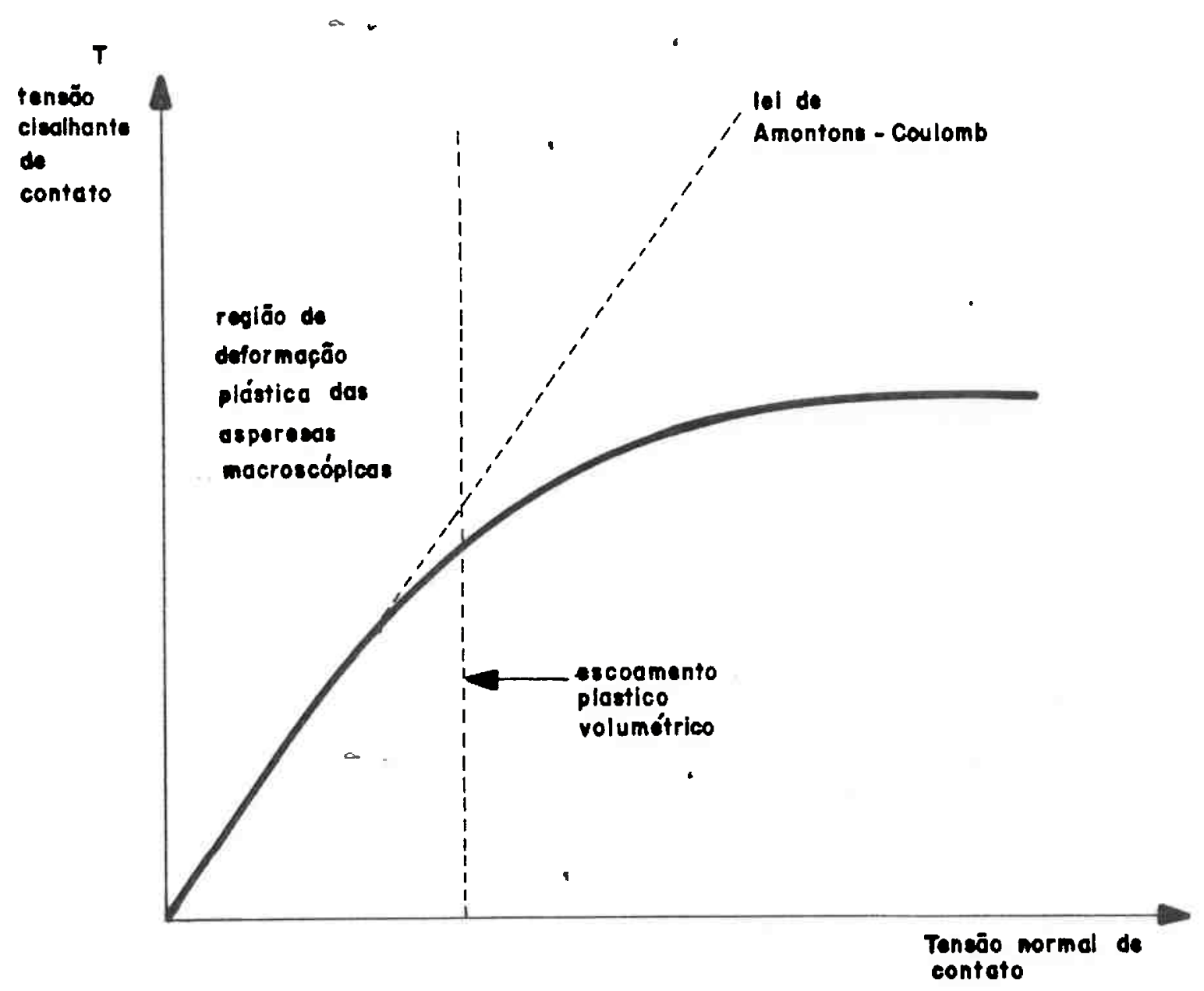

Figura 3.5. - Variação da tensão de cisalhamento em função da tensão de contato AVITZuR ${ }^{62}$. 
Nos trabalhos de conformação plástica,' as pressões normais nas interfaces são bastante elevadas $e$, nestas condições, um segundo modelo de átrito tem sido muito utilizado: o chamado modelo proporcional, de camada ou de cisalhamento máximo, onde a tensão de atrito não é proporcional na interface, mas sim à tensão limite de escoamento do material.

Para um material que obedeça o critério de escoamento plástico de HUBER-VON MISES-HENCKY, tem-se:

$$
\tau=\mathfrak{m} \frac{\sigma_{0}}{\sqrt{3}}
$$

sendo:

$\mathfrak{m}$ : denominado de fator de atrito, é também dependente da natureza das superficies em contato, da presença ou não de lubrificantes e da temperatura entre outros

Ambas as leis de atrito citadas sãofundamentalmente dependentes da velocidade relativa tangencial entre as superfícies.

Se houver caso de lubrificação hidrodinâmica, um terceiro modelo, discutido por AVITZUR ${ }^{59}$, é proposto, de modo tal que :

$$
\tau=\eta \frac{\Delta \mathbf{v}}{\mathrm{h}}
$$

$\eta$ : coeficiente de viscosidade do fluido

$\Delta v$ : velocidade relativa tangencial entre duas superficies separadas por uma dimensão característica $h$.

h : espessura da pelicula lubrificante. 
Os dois primeiros modelos estão relacionados, de modo que seja possível suas conversães recíprocas. Essas comversões, dadas por OROWAN e SHAW, caraaterizam o fenómeno de transição existente nos estudos de atritos $e$ suas interações com os materiais. Os modelos OROWAN e SHAW foram estudados por WANHEIM $e$ $\mathrm{BAY}^{67}$, e são mostrados nas figuras 3.6 e 3.7 .

THOMSEN ${ }^{36} e$ colaboradores mostram que, no limite da aderência, pela lei de atrito de COULOMB, o estado de tensão é uniaxial em sistema cilindro-metálico-matriz em contato por pressão normal, na forma:

$$
-\sigma_{z}=p=\sigma_{0}
$$

e pelo critério de HUBER-VON MISES-HENCKY, tem-se:

$$
\tau_{\max }=\frac{\sigma_{0}}{\sqrt{3}}
$$


Tatrito

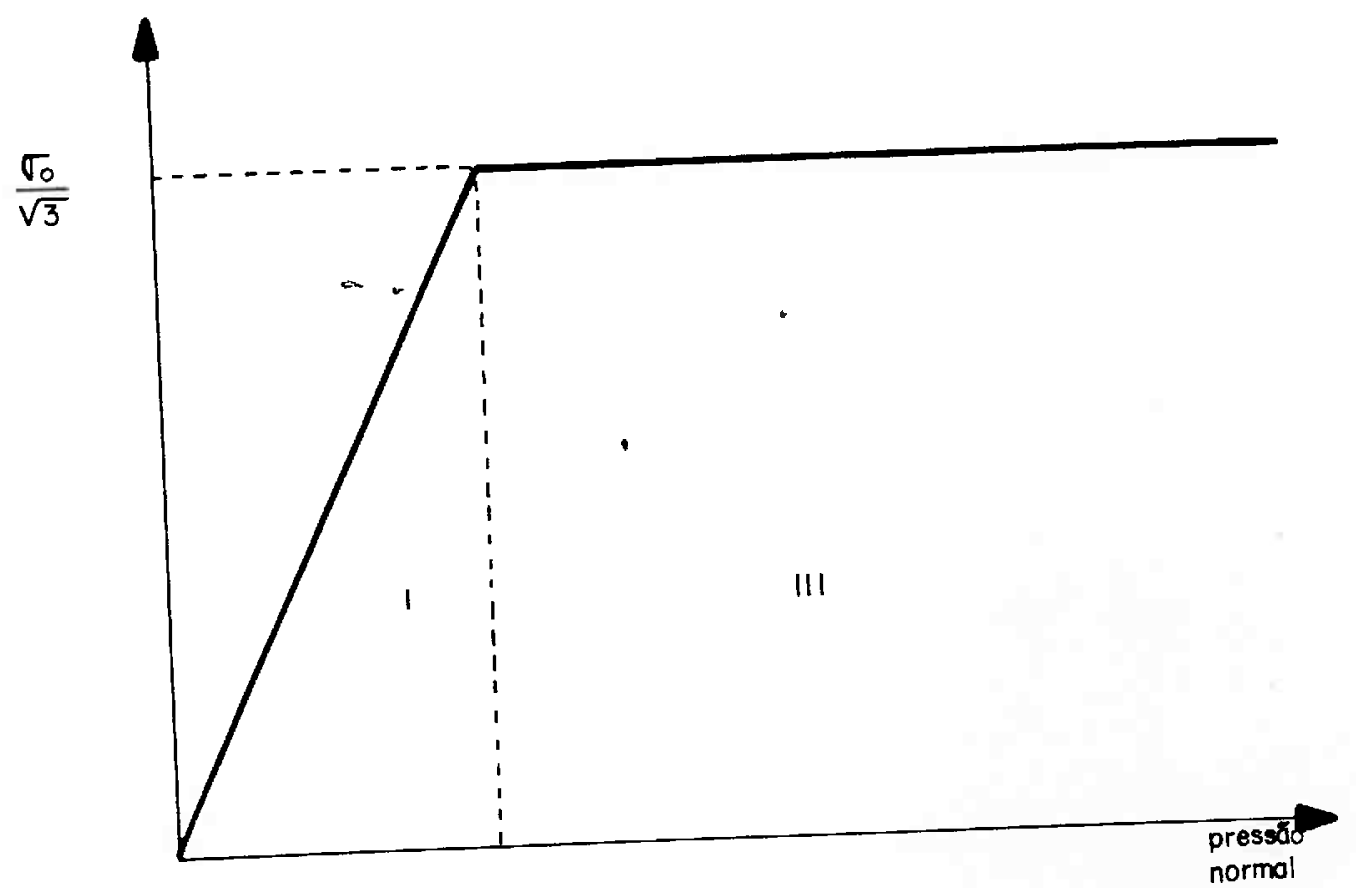

Figura 3.6 - Modelo de atrito de OROWAN. Separação do atrito em dois mecanismos independentes. Região I - modelo elástico. Região II - modelo plástico in: WANHEIM e $\mathrm{BAY}^{69}$. 


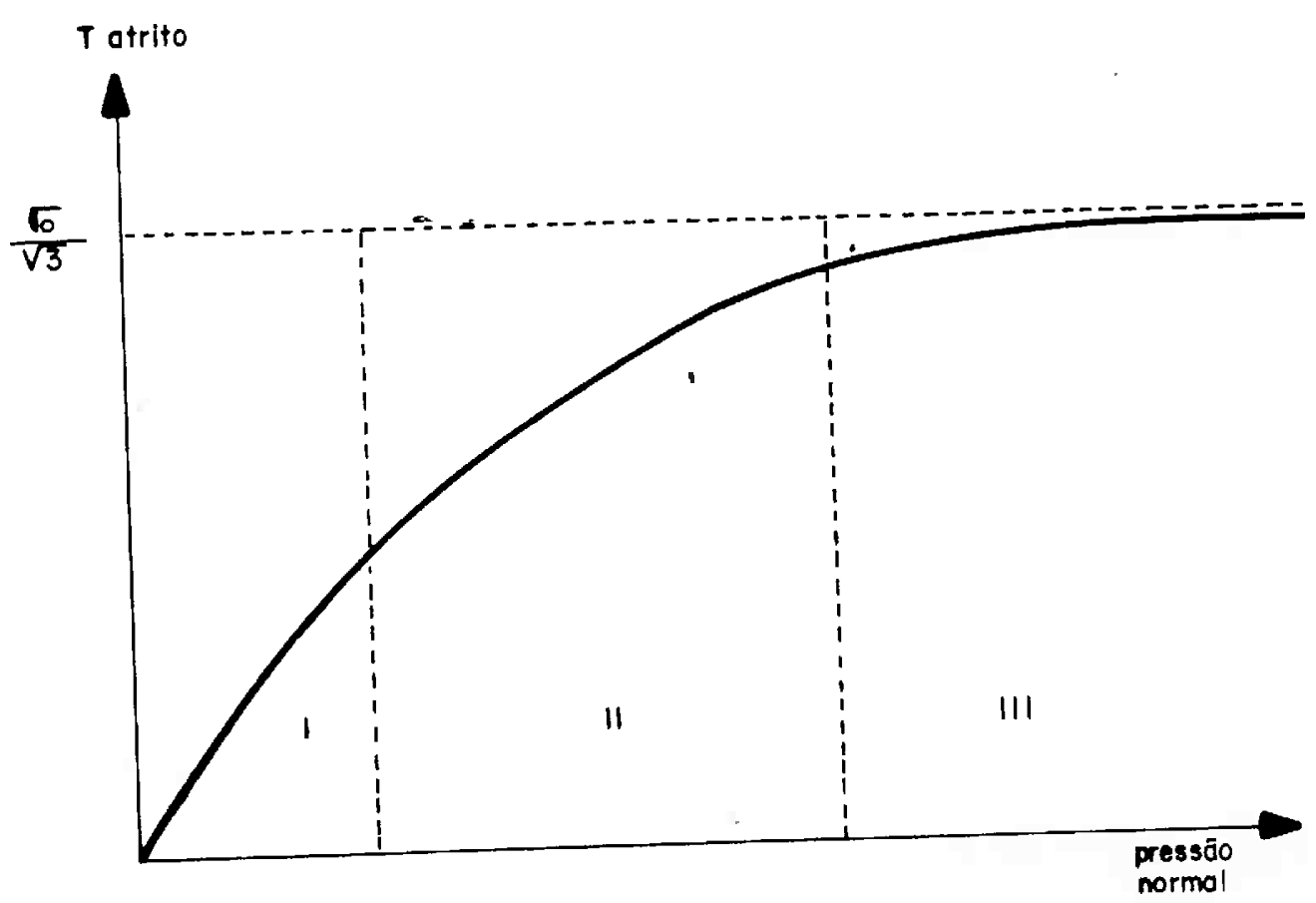

Figura 3.7 - Modelo de atrito de SHAW. Mecanismo de atrito apresentando transição.

Região I - modelo elástico

Região III - modelo plástico

Região II - região de transição

em : WANHEIM e BAY ${ }^{69}$ 
O modelo de OROWAN, discutiso em WANHEIM e BAY ${ }^{69}$, mostra que, na condição limite:

$$
\tau_{\max }=\mu \mathrm{p}
$$

Substituindo 3.141 por 3.140 , obtem-se:

$$
\mu=\frac{\tau_{\max }}{p}=\frac{\sigma_{0} / \sqrt{3}}{\sigma_{0}}=\frac{1}{\sqrt{3 \omega}}
$$

No modelo de atrito de camada:

$$
\tau_{\max }=\mathrm{m} \frac{\sigma_{\mathrm{o}}}{\sqrt{3}}
$$

e atinge um máximo quando $\mathrm{m}$ for a unidade.

Relacionando 3.142 e 3.143 , obtém-se a conversão:

$$
\ldots \quad \mu \simeq \frac{\mathrm{m}}{\sqrt{3}} .
$$

As equações $3.141,3.143$ e 3.144 são adequadas ao estudo proposto neste trabalho, mas são, na realidade simplificações de uma situação prática bastante complexa, como atestam os trabalhos de SHIMA ${ }^{68}$ e colaboradores, de HALLING ${ }^{69}$ e de NAGARAJ ${ }^{70}$. 


\section{REFERENCIAS BIBLIOGRAFICAS - Capitulo 3}

1. JOHNSON, $W$ and MELLOR, P.B. Engineering Plasticity. Ellis Horwood, Chichester, England, 1983, pp.23-27.

2. ORLANDER, R. Fundamental Aspects of Nuclear Reactor Fuel Elements. Chapter 1 - Mechanical Properties of $\mathrm{UO}_{2}$, Technical Information Center of US Department of Energy.,. Washington, DC, 1976, pp.333-372

3. POLUKHIN, P.; GORELIK, s. and VORONTSOV, V. Physical Principles of Plastic Deformation. Chapter 13 - Ductility and Deformation of Metals and Alloys. AFANASYEV, $V$. (tradutor), Mir, Moscow, 1983. pp.373-437.

4. GAROFALO, F. Fundamental of Creep and Creep Rupture in Metals. Chapters 2,3,4,5 e 6, MacMillan, New York, 1965, pp.27-175.

5. ASHBY, M.F. A first report on deformation mechanism maps. Acta Metallurgica, 20:887-897, Jul.1972.

6. GANDHI, C. and ASHBY, M.F. Fracture mechanism maps for materials which cleave: FCC and HCP metals and ceramics. Acta Metallurgica, 27(10):1565-1602, 1979.

7. ASHBY, M.F.; GANDHI,C. and TAPLIN, D.M.R. Fracțure mechanism maps and their construction for FCC metals and alloys. Acta Metallurgica, 27(5):669-729, 1979.

8. MILLER, D.A. and LAGNDON, T.G. Creepfracture maps for 316 stailess steel. Metallurgical Transactions A, 10A:1635-1641, Nov. 1979 .

9. ZENER, C. and HOLLOMON, J.H. Effect of strain rate upon plastic flow of steel. Journal of Applied Physics, 15:22-32, 1944.

10. DADRAS, P. Flow stress equations for type 304 śtainless and AISI 1055 steels. Transactions of the ASME Journal of 
Engineering Materials and Technology, 107(2):97-.100, 1985.

11. SHERBY, O.D. and WADSWORTH, J. superplasticity and superpasticity forming processes. Material Science and Technology, 1(11):925-936, 1985.

12.PRAGER, W. Non-isothermal plastic deformation. 'Proceedings Koninklijke Nederlandse, Akademie von Wetenschappen, Amsterdam, 61:176-182, 1958; Op.Cit. in: zYCzKowsKI, $M$. Combined Loadings in the Theory of Plasticity. PMN - Polish Scientific Publisher. Warszawa, 1981, pp.193-195.

13. HILL, R. A variational principle of maximum plastic work in classical plasticity. Quartely Journal of Mechanics and Apllied Mathematics, 1:18-28, 1948.

14. KACHANOV, L.M. Fundamentals of the Theory of Plasticity. Chapter II - Equations of plastic state. Moscow, Mir, 1974. pp. 48-105.

15. PRANDTL, L. Spanñungsverteilung ' in plastischen Körpern. Proceedings of $1^{\text {st }}$ International congress of Mechanics. Delft, 1924. pp.43-54. Op. cit. Ref. (20) do capítulo 1 .

16. REUSS, A. Berücksichtigung der Elastichen Formäderungen in der Plastizitätstheorie. Zeitschrift für Angewandte Mathematik und Mechanik, Berlin, 10(3):266-274, 1930.

17. LEVY, M. Mémoire sur les équations générales. Cómptes Rendus Hebdomadaires des Séances de 1'Academie des Sciences, Paris, $70: 1323-1325 ; 1870$.

18. VON MISES, R. Mechanik der festen körper. In: Plastich Deformablen zustant. Göttinger Hachrichten, Mathematish Physikalische Klâsše, 1(4):1913, 1913.

19. HENCKY, H.Z. Zur theorie plastischer deformationen und der 
hierduch im material hervorgerufenem nebenspannunger. Zeitschrift für Angewandte Mathematik und Mechanik, Berlin, 4:323, 1924. In: SLATER, R.A.C. Op. cit., ref. (7) do capitulo 1, e HILL, R. op. cit. ref. (2) do capitulo 1.

20. NADAT, A. Der Begîn des Fliessvorganges in einem tordiertem stab, Zeitschrifür Angewandte Mathematik und Mechanik Berlin, 3(3):442-444, 1923.'

21. ZYCZKOWSKI, M. Combined Loadings in the Theory of Plasticity. PWN - Polish Scientific Publishers, Varsóvia, 1982.

22. LUDWICK, P. Elemente der Technologischen Mechanik, Berlin, Springer, 1909, in: JOHNSON, $W$ and MELLOR, P.B. Engineering Plasticity. Ellis Horwood, Chichester, England, 1983, pp.15.

23. HOLLOMON, J.H. Tensile Deformation. Trasnsactions of AIME, $162: 268-290,1945$.

24. VOCE, E. The relationship between stress and strain for homogeneous deformation. The Journal of the Institute of Metals, 74:537-562, 1948 .

25. SWFT, H.W. Plastic instability under plane stress. Journal of Mechanics and Physiscs of Solids, 1(1):1-18, 1952.

26. RAMBERG, W. and OSGOOD, W. Description of stress-strain curves by three parameters. NACA TN 902, Jul.1943. Op.Cit. in: SLATER, R.A.C. Engineering Plasticity. Mac Millan, London, 1977, pp.131.

27. LOVE, A.E.H. A Treatise on the Mathematical. Theory of Elasticity. ChaptervII - General theorems. Cambridge University, 1934, pp.97-108.

28. PRAGER, W. On isotropic materials with continuous transition from elastic to plastic state. 5ih International Congress 
of Applied Mechanics, Cambridge, MA, 1938. pp.234-237.

29. Op.Cit. Ref.21, pp.199-205.

30. HILL, R. A theory of the yielding and plastic flow of anisotropic metals. Proceedings of the Royal Society. London. Series A, n- 193, 1948, pp. 281-297.

31. -----. Theoretical plasticity of textured aggregates. Mathematical Proceedings of Cambridge Phylosophical society. $85: 179-191,1979$.

32. FUNG, Y.C. Foundations of solid mechanics. Prentice-Hall, Englewod Cliffs, New Jersey, 1965, pp.31-153.

33. VLASOV, V.z. The Compatibility Equations in curvilinear Coordinates. PMM - Prikladnaya Matematika e Mekhanika. $8(4): 301-306,1944$.

34. NADAI, A. Theory of Flow and Fracture of Solids " Chapter 4 Behavior of Matter under High Pressure,' New York, McGraw-Hill, 1950, pp. 33-37.

35. BRESCIANI FIIHO, E. (coordenador). Conformação Plástica dos Metais. Volumes $i ̀$ é 2. Editora da UNICAMP, Campinas-SP, 1986. pp. 86-101.

36. THOMSEN, E.G.; YANG, C.T. and KOBAYASHI, S. Plastic Deformation in Metal Processing. Chapter 10 - Some methods of solution of forming problems. Mac Millan, New York, 1965, pp. $158-216$.

37.HIDELBRAND, F.B. Methods of Apllied Mathematics. "Chpater two: Calculus of variations and applications. Prentice-Hall, Englewood Cliffs, New Jersey, 1965, pp.119-121.

38. RICHARDS, T.H. Methods in stress analysis. Chapter six: Variational principles in solid continuum mechanics. Elli 
Horwood, Chichester, England, 1977, pp.211-270.

39. SOKOLNIKOFF, I.S. Tensor Analysis - theory and applications to geometry and mechanics of continua. Second edition, chapter six - Mechanics as Continuous Media. Jonhn Wiley, New York, $1064, \mathrm{pp} .313-352$.

40. ZIENKIEWICZ, O.C. The finite element method. Chapter three: Generalization of the Finite Element concepts - Weighted Residual and Variational Approaches. $3^{\text {rd }}$ edition, Mc-Graw-Hill, London, 1977, pp.42-92.

41. LOVE, A.E.H. A treatise on the Mathematical Theory of Elasticity. Chapter VII - General Theorems. Cambridge University, London, 1934, pp.166-175.

42. HILI, R. The Mathematical Theory of Plasticity. Clarendon, Oxford, 1950. Chapter III - General Theorems, pp'50-69.

43. WYLIE, C.R. Advanced Engineering Mathematics. McGraw-Hill, New York, 1975. pp.650-658.

44. CoOK, R.D. Concepts and Applications of Finite Element Analysis. Chapter 3 - Potential Energy and the Ray leigh Ritz Method. Johñ W̌iley, New York, . 1981, pp.56-76.

45. MARKOV, A.A. On variational principles in the theory of plasticity. PMM - Priklafnaia Matematika i Mekanica (Soviet Journal). 11:339-350, 1947 .

46. HILL, R. General Method of analysis for metal-working processes.International Journal pf Mechanical Science. $16: 521-540,1974$.

47.LAHOTI,G.D. and KOBAYASHI, S. On Hill's General Method of Analysis for Metal-working Processes. International Journal of Mechanical Science. 16:521-540, 1974. 
48. PRAGER, w. and HODGE, P.G. Theory of Perfectly Plastic Solids, John Wiley, New York, 1951, pp. 123-168 e pp. 231-257.

49. HILL, R. Op. Cit. Referência 42, pp.128-160.

50. KACHANOV. Op. Cit. Referência 14, pp.148-242.

51. TARNOVSKI, I, Ya.; POZDEEV,A.A. and GANAGO, O.A. Deformation and Forces in Metal Forming. National Science and Technology Co.; Machine Building Literature, Moscow, 1959, (Russian), op.Cit. in AVITZUR, B. and VAN TYNE, C.J. Ring Forming: An upper bound approach. Part 1: flow pattern and calculation of power. Transaction of the ASME Journal of Engineering for Industry. 104:231-236, 1982.

52. KUDO, H. Some analytical and experimental. studies of axisymmetric - cold forging and extrusion. Part I. International Journal of Mechanical Sciences. 2:102-127, 1960.

53. ------. Some analytical and experimental studies of axisymmetric - cold forging and extrusion. Part II. International Journal of Mechanics Sciences. 3:91-117, 1961.

54. ----. An upper-bound approach to plane strain forging and extrusion. Part I. International Journal of Mechanical Sciences. 1:57-83, 1960 .

55. -----... An upper-bound approach to plane strain forging and extrusion. Part II. International Journal of' Mechanical Sciences. 1:229-252, 1960 .

56. AVITZUR, B. Forging of hollow disk. Israel Journal of Technology . $2: 295-304$.

57. KOBAYASHI, S. Upper-bound solutions of axisymmetric forming problems - I, Transactions of the Journal of Engineering for Industry, May, 1964, pp.122-126. 
58. -----. Upper-bound solutions of axisymmetric forming problems - II,Transactions of the Journal of Engineering for Industry, May, 1964, pp.326-332.

59. AVITZUR, B. Metal Forming: processes and: analysis. McGraw-Hill, New York, 1968, pp.77-491.

60. AMONTONS, G. De la Resistance Couswe dans les Machines, Histöire de L'Acädémie Royale des.Sciences avec les Mwmoires de Mathematique et de Physique, 1699. pp. 206.

61. COULOMB, C.A. Memoires de Mathematique et de Physics de L'Academie Royale des Sciences. 1781, p. 161.:Op.Cit. in: THOMSEN, E.G. et alii..., Referência 36, pp.217-229.

62. AVITZUR, B. Handbook of Metal Forming, pp. 945-971.

63. MALE, A.T. and COCKCROFT, M.G. A method for determination of the coefficient of friction of metals under conditions of bulk plastic deformation. Journal of the Institute of Metals. $63: 38-46,1964$.

64. LEE, C.H. and ALTAN, T. Influence of flow stress and friction upon metal flow in upset forging of rings and cylinders. Transactions of the ASME Journal of Engineering for Industry. Aug.1972, pp.775-782.

65. SCHEY, J. (editor). Metal Deformation Processes: friction abd lubrication. Dekker, New York, 1970.

66. BRESCIANI FILHO, E. Conformação Plástica de Chapas de Aço Galvanizadas. Tese de Livre-Docência, Escola Pọitécnica da Universidade de São Paulo, 1980.

67. WANHEIM, $T$. and $B A Y, A$ model for friction in metal forming processes. Annals of the CIRP. 26(1):189-194, 1978 .

68. SHIMA, S.; WATANABE, Y. and OYANE, M. Effect of tool-workpiece 
contact lenght on lubrication in metal forming. Transcations of the ASME Journal of Tribology. 107(2):211-215, 1985.

69. HALLING, J. A contribution to the theory of friction. Wear, $37(1): 169-184.1976$.

70. NAGARAJ, H.S. Elastoplastic contact of bodies with friction under normal and tangential loading. Transactions of the ASME Journal of Tribology. 106(4):519-526, 1984 


\section{MECANICA DA FRATURA NAOO-LINEAR E AS INTEGRAIS INVARIANTES}

\subsection{Fundamentos da Mecânica da Fratura Linear e Năo-Linear}

A fratura mecánica é definida como uma disciplina que estuda a possibilidade da ocorrência de falhas e rupturas numa estrutura, causada pela propagação de um defeito presente e predominantemente do tipo trinca, BRUST ${ }^{1}$. Apesar de haver um grau elevado de complexidade nos mecanismos microestruturais que ocasionam a fratura dúctil, segundo JENNER e DODD ${ }^{2}$, tem havido um número grande de tentativas para descrever os processos de fraturas. Algumas teorias são de natureza fenomenológica, ou seja, não consideram os efeitos das mudanças microestruturais, pelo contrário, são resultados de análises teóricas, baseadas em observações do comportamento microestrutural, onde o trabalho de BATES $^{3}$ descreve as principais teorias desses tipos.

com o objetivo de construir um "critério de conformabilidade, fundamentado na mecânica da fratura, este trabalho será orientado pela concepção fenomenológica.

A mecânica da fratura linear elástica é limitada às condições de escoamento plástico em uma zona que " contendo a ponta da trinca, é ao mesmo tempo de pequena dimensão. É virtualmente impossivel satisfazer as condições da presença de trincas em zonas plásticas de pequenas dimensões para materiais que possuam alta tenacidade à fratura, baixa resistência mecânica, sofra de extensiva dẽfómação plástica e que tenha a ponta da trinca sofrendo um arredondamento antes do início da sua propagação. A necessidade de se incluir a influência da deformação plástica, que acompanha a iniciação e o subseqüente crescimento estável da trinca, é o que tem sido o principal fator para o 
desenvolvimento da mecânica da fratura não-linear, KANNINEN ${ }^{4}$.

Uma antiga tentativa de modelar o comportamento de uma trinca dentro de uma matriz plástica se deveu a DUGDALE ${ }^{5}$, que considerou a dimensão da zona plástica muito maior que a espessura da chapa, o qual modelou esta zona como sendo uma faixa escoada à frente da ponta da trinca, considerando o material, elástico perfeitamente plástico. o mesmo pesquisador postulou que o efeito do escoamento era aumentar a dimensão da trinca pela extensão da zona plástica, dentro de um meio infinito, submetido a uma tensão remota e uniforme, como mostra a'figura 4.1 .

o modelo da figura 4.1 é representado pela fórmula:

$$
u_{2}\left(a, 0^{+}\right)-u_{2}\left(a, 0^{-}\right) \equiv \delta_{t}=\frac{8}{\pi} \frac{\sigma}{E} \text { a } \ln \left[\sec \frac{\pi}{2} \frac{\sigma}{\sigma_{2}}\right] \quad 4.1
$$

$\hat{E}$ possivel observar ser $\delta_{t}$ uma medida da déformação que ocorre na zona plástica. Dentro deste conceito, um critério de fratura elasto-plástica, pode ser expresso, em função de um valor crítico, onde no inicio do crescimento da trinca, tem-se:

$$
\delta_{t}=\delta_{t c}
$$

onde $\delta_{t c}$ é um valor crítico, considerado como uma propriedade material e $\delta_{t}$ é $O$ deslocamento dé abertura da trinca. BROEK $^{6}$ mostra uma revisão extensa desse critério de fratura e alguns métodos para a medida de $\delta_{t}$. Posteriormente, ter-se-á $J=\sigma_{0} \delta_{t}$ e, portanto:

$$
J=\frac{8}{\pi} \frac{\sigma_{0}{ }^{2}}{\mathrm{E}} \text { a } \ln \left[\sec \left(\frac{\pi}{2} \frac{\sigma}{\sigma_{0}}\right)\right]
$$

onde a é a distância de propagação da trinca 

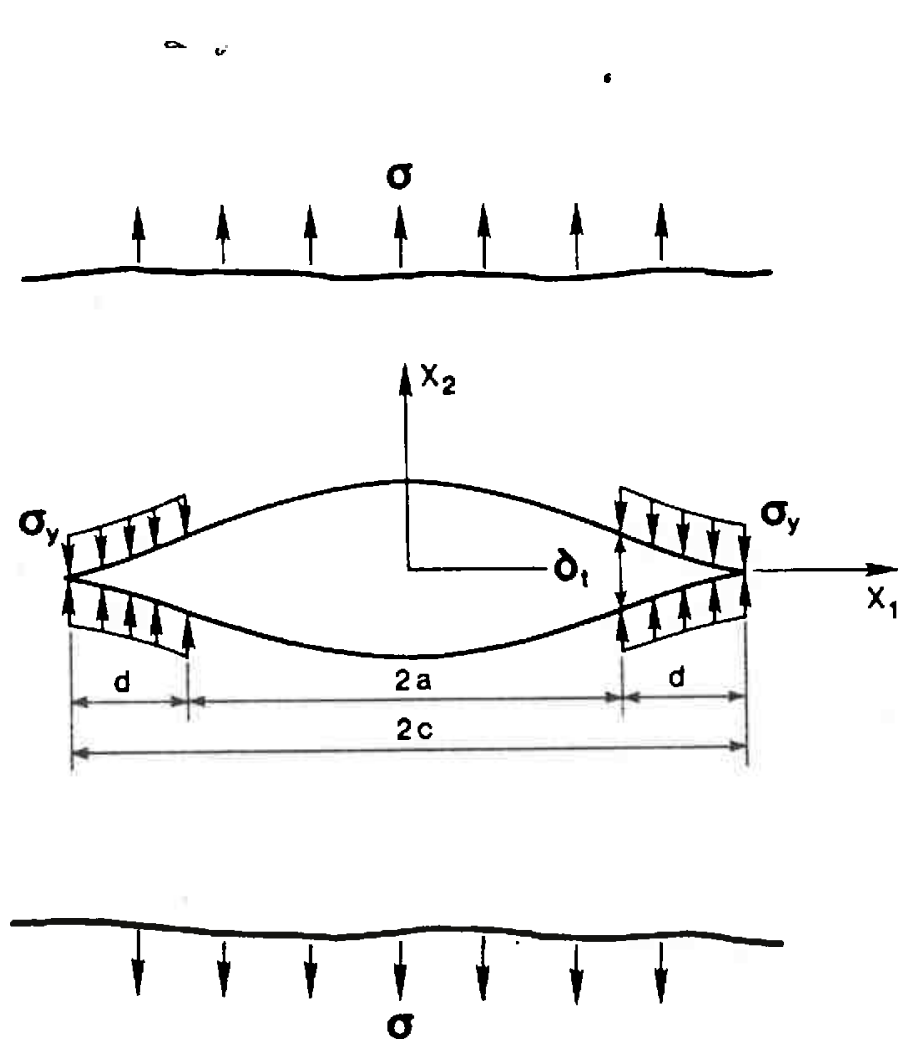

Figura 4.1 - Modelo de DUGDALE para fratura não-linear 
A definição de fratura dúctil em sólidos cristalinos envolve a quebra de ligações atômicas, onde a deformação plástica precede a formação de trincas criando, conseqüentemente, um número elevado de problemas complexos. Esses problemas estão relacionados com os defeitos de redes cristalinas. Os defeitos respondem por si só às forças impostás no solido. As forças de tração, compressão, cisalhamentọ e hidrostática pọdem agir nos defeitos através das várias de suas combinações, provocando o surgimento de campos de tensões e de deformações.

Os campos de tensões e de deformações, então criados, deverão ser conhecidos em todo o corpo sólido, principalmente nas regiões onde as trincas se iniciam e eventualmente se propagam, para possibilitar o desenvolvimento do estudo dos mecanismos microscópicos de fraturas.

Já a análise macroscópica pode ser realizada a partir do conhecimento das condições experimentais, como: dados de tensões e de deformaçōes, geometría da peça de ensaio e observạções óticas. Por exemplo, a iniciação e a propagação de trincas requerem o conhecimento das informações sobre os processos que ocorrem dentro do corpo de teste, em uma escala que exceda a resolução ótica do microscópio em uso, WISDORF ${ }^{7}$.

A caracterização macroscópica da fratura fornece parâmetros importantes para descrever os processos de fraturas, de modo que medidas laboratoriais possam ser utilizadas para prediç̧ão das falhas nas aplicações estruturais de uma peça.

como a mecânica da fratura linear considera o" conceito que relaciona tensões e condições de tensões nas trincas e especialmente nas suas pontas como seu objeto de estiudo, então a 
introdução do fator de intensidade de tensão tem sido provado na prática ser bastante providencial, de acordo com ZHUANG $^{8}$, 0 mesmo é da seguinte forma:

$$
\mathrm{K}=\sigma(2 \pi r)^{1 / 2}
$$

sendo:

$\sigma$ : tensão nominal $\propto$

I : distância radial do ponto longe da ponta da trinca

Quando o valor de $r$ tender para zero, na expressão 4.3, - valor de $K$ atinge um valor crítico $K_{c}$ e neste caso a tensão $\sigma$ tende para valores infinitos. Mas o material deve, localmente, escoar plasticamente para um valor de tensão $\sigma$ igual à tensão de escoamento $\sigma_{0}$, consequentemente uma zona plástica de raio $r_{p}$ se forma na ponta da trinca:

$$
\begin{aligned}
& r_{p}=\frac{1}{2 \pi}\left[\frac{\mathrm{K}}{\sigma_{0}}\right]_{\text {, para estado plano de tensão }}^{2} \\
& r_{p}=\frac{1}{6 \pi}\left[\frac{\mathrm{K}}{\sigma_{0}}\right]^{2}, \text { para êstado de deformação: plana }
\end{aligned}
$$

Três modos de desenvolvimento de trincas existem na mecânica da fratura linear elástica: modo de abertura, modo de cisalhamento e modo de rasgamento, em $\mathrm{KANNINEN}^{9}, \mathrm{com}$ as seguintes respectivas intensidades de tensão: $\mathrm{K}_{I}, \mathrm{~K}_{I I}, \mathrm{~K}_{I I I}$.

A mecânica da fratura linear teve todo seu desenvolvimento derivado dos trabalhos de GRIFFITH ${ }^{10}$ que propôs 
um critério de ruptura pela propagação da trinca, baseado na idéia de diminuição da energia pọtencial elástica no corpo sólido, provocada pela liberação de energia para a formação de superficies livres.

A energia potencial elástica armazenada na trinca é:

$$
U_{\text {elastica }}=-\frac{\pi a^{2} \sigma^{2}}{E}
$$

e a energia de formação de duas superficies livrés é dada por:

$$
\cdots U_{2 s}=2\left(2 \quad a \gamma_{\Delta}\right)
$$

$\gamma_{\Delta}$ : é energia especifica de formação de superficie livre a : semi-comprimento de trinca

A variação de energia no sistema, devido à propagação da trinca, é dada pela condição de instabilidade:

$$
\frac{\partial \mathrm{U}_{\text {total }}}{\partial \mathrm{a}}=\frac{\partial}{\partial \mathrm{a}}\left\{\mathrm{U}_{\text {elastica }}+\mathrm{U}_{\text {superficie }}\right\}=0
$$

ou seja:

$$
\frac{\partial}{\partial a}\left\{-\frac{\pi a^{2} \sigma^{2}}{s \sigma}+4 a \gamma_{\Delta}\right\}=4 \gamma_{\Delta}-\left(\frac{2 \pi \sigma^{2} a}{E}\right)=0
$$

onde finalmente a tensão crítica'é dada por:

$$
\sigma=\left\{\frac{2 E \gamma_{\Delta}}{\pi a}\right\}^{1 / 2}
$$


válida para o estado plano de teñsão.

No caso do estado plano de deformação, substituir E por:

$$
\mathrm{E} /(1-v)^{2}
$$

o caso tridimensional é modelado segundo uma esferóide achatada nos polos e possui uma expressão similar à de GRIFFITH, e a mesma foi proposta por $\mathrm{SACK}^{11} \mathrm{em} 1947$.

- cálculo da concentração de tensão na região perto da ponta da trinca é baseado no modelo elástico de INGLIS ${ }^{12}$.

o modelo de fratura de INGLIS-GRIFFITH-SACK é válida apenas para materiais Irágeis, nos quais uma trinca se propaga com uma velocidade de cerca de $38 \%$ da velocidade de propagação do som no meio material, para uma tensão resolvida menor que a tensão de escoamento do material como foi previsto por MOTT ${ }^{13}$.

o modelo de GRIFFITH é irrealístico para a maioria dos metais, porque os mesmos não são verdadeiramente frágeis. Uma correção, devida a OROWAN ${ }^{14}$, acrescenta ao modelo anterior uma parcela de energia correspondente àquela dissipada pela deformação plástica. Essa correção explica a alta tenacidade à fratura presentes nos materiais metálicos, e é dada na forma:

$\gamma_{e}=\gamma_{0}+\gamma_{p} \quad 4.8$ WILLIAMS $^{15} e^{\circ}$ IRWIN $^{16}$ comprementaram $\circ$ modelo de INGLIS-GRIFFITH-SACK, corrigido, por OROWAN, apresentando as seguintes formulações, segundo as notações algébricas de ERDOGAN $^{17}$, figura 4.2 :

a) Modo I ou da abertura da trinca no estado plano de deformação:

$$
\begin{aligned}
& \sigma_{11}=f_{I}(r) g_{I} 1 \mathrm{l}(\theta) \\
& \sigma_{x z}=\sigma_{y z}=0 \text { e } \sigma_{z z}=v\left(\sigma_{x x}+\sigma_{y y}\right)
\end{aligned}
$$


b) Modo II ou do cisalhamento (arrastamento) da trinca no estado plano de deformação:

$$
\begin{aligned}
& \sigma_{11}=f_{I I}(r) \quad g_{I I}^{11}(\theta) \\
& \sigma_{z z}=v\left(\sigma_{x x}+\sigma_{y y}\right) \text { e } \tau_{x z}=\tau_{y z}=0 \quad 4.10 b
\end{aligned}
$$

c) Modo III ou estado do rasgamento da trinca no estado plano de deformação:

$$
\begin{gathered}
\sigma_{1 j}=f_{I I I}(r) g_{I I I}(\theta) \\
\sigma_{x x}=\sigma_{y y}=\sigma_{z z}=\sigma_{x y}=0
\end{gathered}
$$

para as seguintes condições e fatores de intensidade de tensão, $\mathrm{K}_{\mathrm{I}}, \mathrm{K}_{\mathrm{II}}$ e $\mathrm{K}_{\mathrm{III}_{\mathrm{I}}}$ :

$$
\begin{array}{cc}
f_{I_{I}}(r)=K_{I}(2 \pi r)^{1 / 2} & 4.11 c \\
K_{I}=\lim _{r \rightarrow 0}(2 \pi r)^{1 / 2} \sigma_{x y} & 4.12 \\
g_{I} \times x(\theta)=\cos (\theta / 2)\left[1-\operatorname{sen}(\theta / 2) \operatorname{sen}\left(\frac{3 \theta}{2}\right)\right] & 4.13 a \\
g_{I} y y(\theta)=\cos (\theta / 2)\left[1+\operatorname{sen}(\theta / 2) \operatorname{sen}\left(\frac{3 \theta}{2}\right)\right] & 4.13 b \\
g_{I} x y(\theta)=\operatorname{sen}(\theta / 2) \cos (\theta / 2) \cos \left(\frac{3 \theta}{2}\right) & 4.13 c \\
I_{I I}(r)=-(2 \pi r)^{1 / 2} \cdot K_{I I} & 4.14
\end{array}
$$




$$
\begin{aligned}
& \mathrm{K}_{\mathrm{II}}=\lim _{r \rightarrow 0}(2 \pi r)^{1 / 2} \sigma_{x y} \\
& a \text {. } \\
& g_{I I} \times x(\theta)=\operatorname{sen}(\theta / 2)\left[2 \cos (\theta / 2) \cos \left(\frac{3 \theta}{2}\right)\right] \\
& g_{I I} y y(\theta)=\operatorname{sen}(\theta / 2) \cos (\theta / 2) \cos \left(\frac{3 \theta}{2}\right) .4 .16 b \\
& f_{I I I}(r)=-K_{I I I}(2 \pi r)^{1 / 2} \\
& g_{I I I} x z=\operatorname{sen}(\theta / 2) \\
& g_{I I I} y z=\cos (\theta / 2)
\end{aligned}
$$

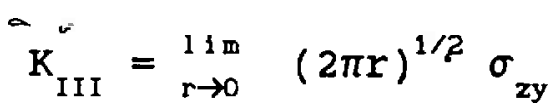

$$
\begin{aligned}
& 4.18 a \\
& 4.18 b
\end{aligned}
$$



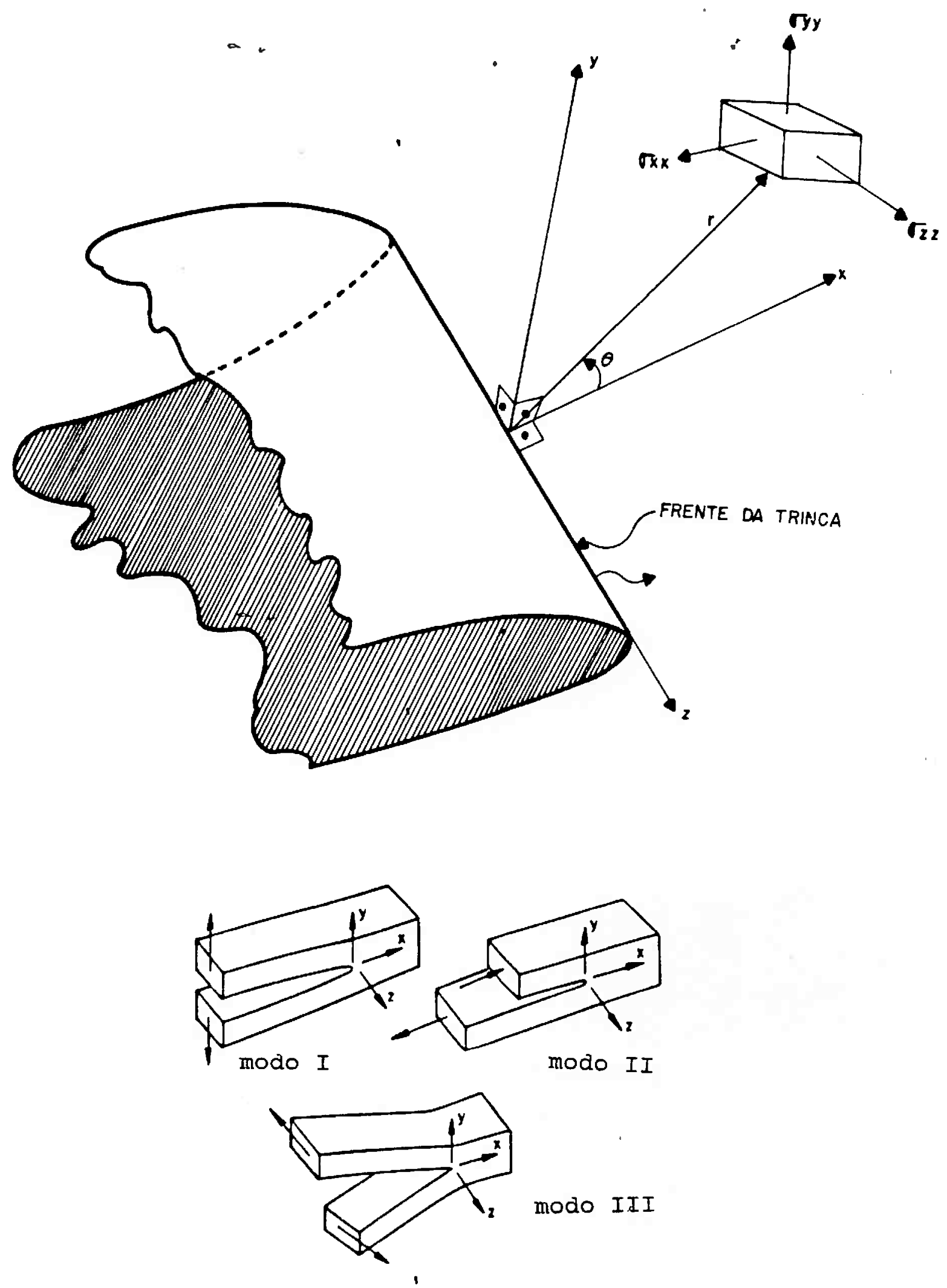

Figura 4.2 Representação geométrica do campo de tensões numa frente de trinca 
Para converter os casos para o estado plano de tensão fixar a tensão $\sigma_{2 z}=0$ e substituir $v$ por $\frac{v}{1+\nu}$.

As taxas de liberação de energia, associadas a uma extensão Incremental đe trinca são da fọma:

$$
\begin{gathered}
G_{I}=K_{I}^{2} / E ; \text { estado plano de tensão } \\
G_{I}=\left(1-v^{2}\right) G_{I} ; \text { estado plano de deformação } \\
G_{I I}=K_{I I}^{2} / E ; \text { estado plano de tensão } \\
G_{I I}=\left(I-v^{2}\right) G_{I I} ; \text { estado plano de deformação } \\
\quad G_{I I I}=(1+v) \mathrm{K}_{I I I}^{2} / E
\end{gathered}
$$

No caso de extensão da trinca sob condição de carregamento combinado, obtém-se'o seguinte:

$$
G_{\text {total }}=G_{I}+G_{I I}+G_{I I I}
$$

As limitações da mecânica da fratura linear elástica levou SANDERS ${ }^{18}$ a propôr, em 1960, um novo critério de propagação de trinca baseado em uma formulação dada por uma integral da linha , de modo que a mesma fosse independente da trajetória de integração. Essa proposta de SANDERS foi desenvolvida seguindo os trabalhos de ESHELBY ${ }^{19}$. que estudou defeitos en sólidos cristalinos modelados dentro da teoria dos meios continuos, e o mesmo sugeriu a integração de linha em torno de região contendo 
defeitos em analogia à teoria eletrostática.

Em 1967 e 1966, CHEREPANOV ${ }^{20} \cdot$ e RICE ${ }^{21}$, independentemente, formalizaram essa proposta de SANDERS para os materiais elasto-plásticos, apoiadas na teoria da deformação plástica de HENCKY.

-Para os materiais metálicos de interesse para os processos de conformação plástica, o modo de fratura dúctil é o mais importante a ser considerado nos estudos da mecânica da fratura e o mesmo ocorre segundo um comportamento não-linear, de acordo com DIETER ${ }^{22}$.

A natureza altamente experimental dos estudos da fratura dúctil, considerando a sua iniciação e propagação, levou ao desenvolvimento de um método de ensaio cuja tentativa era a de relacionaras grandezas de propriedades mecânicas e o estado de tensão na região perto da ponta da trinca com 0 denominado deslocamento de abertura da trinca $\delta_{\mathrm{T}}$.

MCMEEKING ${ }^{23}$ propôs a seguinte expressão, válida para alguns metais ensaiados no estado plano de deformação:

$$
\delta_{T}=0,55\left\{\frac{2}{\sqrt{3}} \times \frac{(1+v)(1+n)}{n E}\right\}^{n}\left(1-v^{2}\right) \frac{K^{2}}{E}
$$

onde:

$\delta_{\mathrm{T}} \equiv \operatorname{COD}$ deslocamento da abertura da trinca

$\mathrm{n}$ : expoente de encruamento na fórmula de HOLLOMON.

$\mathrm{K}$ : fator de intensidade de tensão

$\sigma_{0}:$ tensão de escoamento do material

$v$ : razão de POISSON 
E : módulo de elasticidade ou de 'Young

o modelo experimental de McMEEKING tenta relacionar a propagação da fratura dúctil com a abertura da trinca e mostra, do modo geral, a forte não-linearidade do processo com a dependência funcional de $\delta_{T}$ :

$$
\delta_{T}=f\left(K^{2}\right)
$$

sendo: $K$, de acordo com as equações $4.12,4.15$ e 4.19 , do tipo:

$$
K=f\left(\sigma_{1 j}\right)
$$

- fator de intensidade de tensão $K$, é um parâmetro pontual e o mesmo é de dificil avaliação, mesmo com so auxilio de avançados métodos computacionais.

\subsection{Teorema de NOETHER para as Integrais Invariantes}

As integrais invariantes são parâmetros de:campos e como tal são solidamente construidas dentro da mecânica dos meios contínuos e dentrode concepçōes da teoria contínua das discordâncias. Nessas aintegrais serão sempre considérados volumes e regióes envolvendo tricas e defeitos.

A contribuição de EMMY NOETHER ${ }^{23}$ [1918] para o cálculo de variações consistiu em dois teoremas para as soluções das equações de EULER-LAGRANGE, ambos objetivando resolyer problemas de integrais simples e múltiplas. NOETHER mostrou que se a integral for invariante sob um grupo de mapeamento de funções para outro grupo de funções, as funções estacionárias devem então 
satisfazer as correspondentes condições restritivas qué no caso de problemas de integração simples, a solução toma a forma da primeira das integrais das equações de EULER-LAGRANGE. A primeira das integrais inclui as leis de conservação da física e da mecânica dos meios contínuos.

o teorema de NOETHER é mostrado a seguir como sendo:

para um grupo de transformações:

$$
\begin{gathered}
\mathrm{x}_{\mu} \longrightarrow \mathrm{x}_{\mu}^{\prime}=\mathrm{x}_{\mu}+\delta \mathrm{x}_{\mu} \\
\phi^{\alpha}(\mathrm{x}) \longrightarrow \phi^{\alpha}\left(\mathrm{x}^{\prime}\right) \equiv \phi^{\alpha}(\mathrm{x})+\delta \phi^{\alpha}(\dot{x})
\end{gathered}
$$

for tal que:

$$
\int_{V^{\prime}} \varphi\left[\phi^{\prime \alpha}\left(x^{\prime}\right), \phi^{\prime \alpha}, v^{\prime},\left(x^{\prime}\right)\right] d^{4} x
$$

para todo o volume $\mathrm{V}^{\prime}$,

então:

$$
\frac{\partial f \mu}{\partial \mathrm{x}_{\mu}}=0
$$

onde:

$$
f \mu=\left(\mathscr{L} \delta_{\mu \nu}-\frac{\partial \mathscr{L}}{\partial \phi^{\alpha}, \mu} \phi^{\alpha}{ }^{\prime} \nu\right) \delta \mathrm{x}_{\nu}+\frac{\partial \mathscr{L} \delta \phi^{\alpha}}{\partial \phi^{\alpha}, \mu}
$$
A equação 4.24 e é a expressão da quantidade conservada.
o teorema de NOETHER está demonstrado em CUSHIN!G ${ }^{24}$.

\subsection{Integrais Invariantes e a Mecánica da Fratura Nåo-Linear} (Leis da Conservação da Mecânica dos Meios Contínuos)

As leis de conservação da mecânica dos meios contínuos são baseadas no teorema de NOETHER, que estimuláu ESHELBY ${ }^{19}$ a 
introduzir o conceito de força sobre uma singularidade elástica. E isso foi devido ao grande interesse nos estudos das imperfeições em redes cristalinas da física do estado sólido de um lado, e ao desejo de se modelar tais imperfeiçōes microestruturais dentro do campo da elasticidade clássica com a introdução do conceito de forças sobre uma singularidade elástica.

A força, nesse tipo de singularidade, foi definida como sendo 0 gradiente negativo da energia total do corpo em consideração em relação à mudança da pósição do defeito no corpo. Uma singularida- de elástica pode ser uma discordáncia, uma inclusão, uma vacância ou outros defeitos. ESHELBY mostrou que a força em tal defeito seria o resultado da integração sobre qualquer superficie incluindo o defeito. $\mathrm{Na}$ ausência de defeitos, concluiu êle, a integral de superficie, seria nula e então uma lei de conservação poderia ser estabelecida.

As pesquisas sobre mecânica da fratura plana realizadas por $\operatorname{RICE}^{21}$ sem o conhecimento dos trabalhos anteriọres, conforme HERRMANN $^{25}$, levou-o a representar a força de exțensão de uma trinca de $\operatorname{IRWIN}^{16}$, como sendo uma integral independente do caminho de integração, denominada de ińtegral-J de RICE e a mesma mostrou ser de grande utilidade prática.

As pesquisas de RICE estão intimamente relacionadas às investigaçães de SANDERS ${ }^{18}$ e CHEREPANOV ${ }^{20}$.

KNOWLES e STERNBERG ${ }^{26}$, baseados no trabalho:de ESHELBY e no teorema de NOETHER, descobriram outras integrais invariantes denominadas por BUDIANSKY $e \mathrm{RICE}^{27}$ de integral-L e integral-M .

Essas leis de conservação foram estabelecidas para os problemas do tipo deformação bidimensional, mostrados na figura 
4.3, onde o vetor deslocamento relativo $u_{1}$ depende apenas das coordenadas $x_{1}$ e $x_{2}$ são as seguintes:

a) Integral-J

$$
J=\oint_{c}\left(W\left(\varepsilon_{1 j}\right) d x_{2}-T_{1} u_{1,1}\right) d l
$$

para c: contorno fechado no plano definido pelos eixos $x_{1} e x_{2}$ e $W\left(\varepsilon_{1 j}\right)$ é a densidade de energia de deformação $T_{1}$ : vetor de tensão atuando externo à curva $C$ Na realidade, a integral-J é o primeiro componente de um vetor cujos componentes são definidos por:

$$
J_{k}=\oint_{c}\left(W n_{k}-T_{1} u_{i, k}\right) d l
$$

onde $n_{k}$ é a normal externa à curva $c$, mas contida no mesmo plano. 

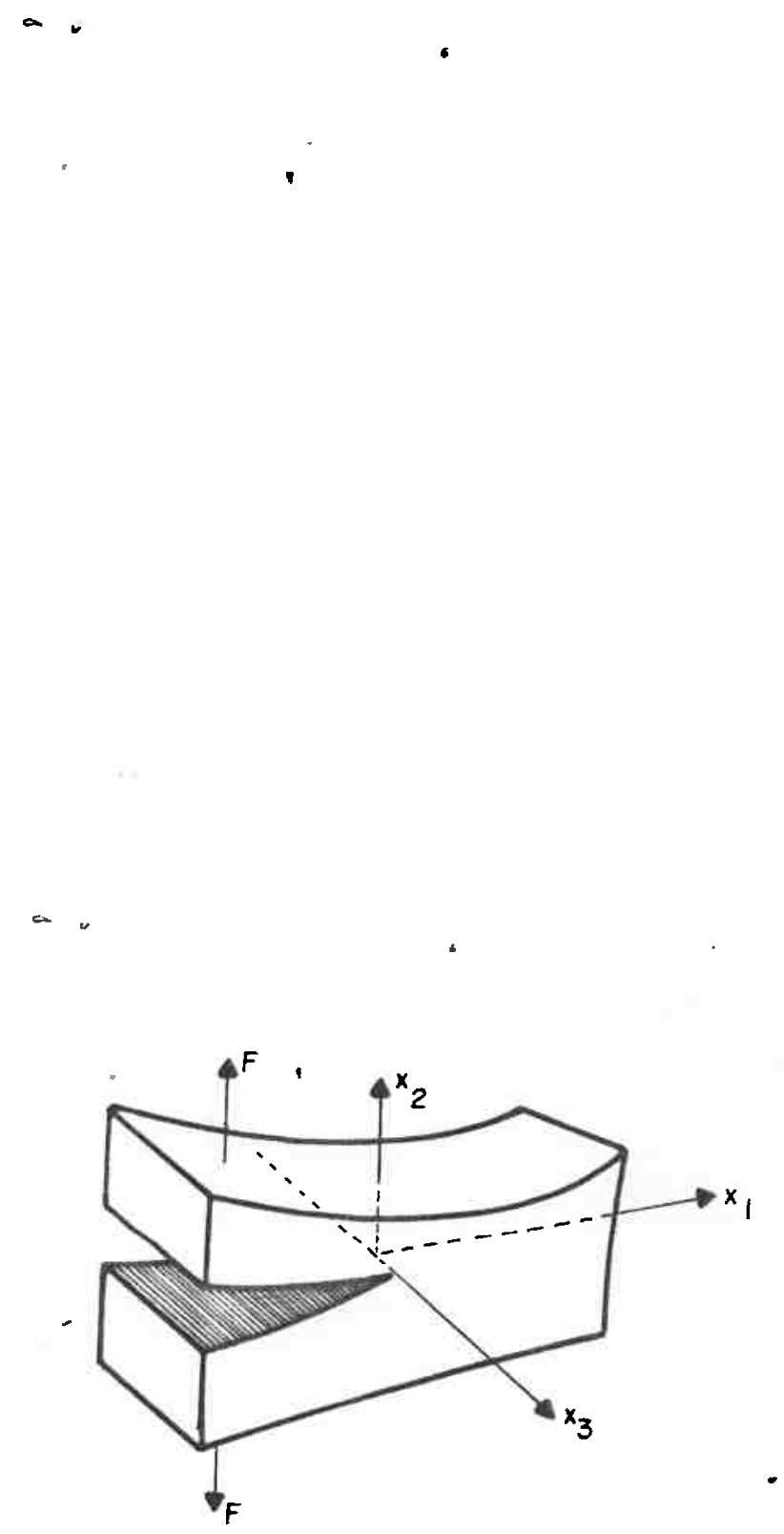

Figura 4.3 Geometria para aplicação das integrais $J$ e M 
A densidade de energia de deformação $W\left(\varepsilon_{1 j}\right)$ é dependente da deformação:

$$
\varepsilon_{11}=\frac{1}{2}\left(u_{1, j}+u_{1,1}\right)
$$

e as tensōes relacionadas ao vetor de tensão $T_{1}$ na curva $C$ são dadas por:

$$
\cdots T_{1}=\sigma_{1 j} n_{1} .
$$

onde as tensões $\sigma_{11}$ satisfazem a relação:

$$
\sigma_{1 j}=\frac{1}{2}\left(\frac{\partial W}{\partial \varepsilon_{1 j}}+\frac{\partial W}{\partial \varepsilon_{11}}\right)
$$

e

$$
\sigma_{1,1,1}=0
$$

As novas integrais de KNOWLES-STERNBERG são para o caso didimensional:

$$
L_{c}=\oint \epsilon_{31 j}\left(W x_{j} n_{1}+T_{1} u_{j}-T_{k} u_{k, i} x_{j}\right) d l:
$$

e

$$
M=\oint_{c}\left(W x_{1} n_{1}-T_{k} u_{k, 1} x_{i}\right) d l
$$

sendo: $\epsilon_{i j k}$ o tensor alternante

No caso tridimensional as integrais invariantes generalizam-se para:

$$
\begin{gathered}
J_{k}=\int_{S}\left(W n_{k}-T_{1} u_{1, k}\right) d S \\
L_{k}=\int_{S} \epsilon_{k 1 j}\left(W x_{j} n_{1}+T_{1} u_{j}-T_{1} u_{1,1} x_{j}\right) d S
\end{gathered}
$$




$$
M=\int_{S}\left(W x_{1} n_{1}-T_{j} u_{j, 1} x_{1}-\frac{1}{2} T_{1} u_{1}\right) d s
$$

sendo, nesses casos:

s uma superficie fechada cuja normal externa é $n_{1}$. Através de cinco teoremas, KNOWLES e STERNBERG ${ }^{26}$ provaram que as fórmulas dadas por 4.25 a 4.35 são leis de conservação:

ESHELBY ${ }^{19}$ e RICE ${ }^{21}$ mostraram que a integrai-J pode ser interpretada como taxa de liberação de energia quando uma cavidade ou ponta de uma trinca transladar relativamente de uma posição para outra no corpo material. BUDIANSKY e $\operatorname{RICE}^{27}$ provam que as integrais $-L_{k} e-M$ também possuem interpretações similares, sendo tambem válidas para análises de problemas da elasticidade não-linear.

A integral-J $J_{k}$ a integral- $I_{k}$ e a integral-M são conhecidas como taxas de liberação de energia para translação, rotação e expansão auto-similar, respectivamente.

Em 1980, KISHIMOTO, AOKI e $\operatorname{SAKATA}^{28}$ apresentaram a integral-ĵJ como sendo a taxa do fluxo de energia para uma região de processo envolvendo a propagação e extensão de ţrincas . Essa integral é uma extensão da integral-J de RICE e inclui a existência de uma região de processo de fratura em conjunto com os efeitos das deformações pıásticas, forças centrais de corpo, deformações térmicas e inércia material.

A formulação de KIsHIMoTo $^{28}$ e colaboradores é a que segue: 
(a) Equação do balanço de energia

A equação de movimento de um sólido é dada por:

$$
\sigma_{1 \mathrm{~J}, \mathrm{~J}}+\mathrm{F}_{1}=\rho \ddot{\mathrm{u}}_{1}
$$

multiplicando ambos os lados da equação 4.36 pela velocidade $u_{1} e$ integrando no elemento de volume, obtém-se:

$$
\int_{V}\left(\sigma_{q_{k, j}}+F_{1}\right) \dot{u}_{1} d V=\int_{V} \rho \ddot{u}_{1} \dot{u}_{1} d v
$$

A transformação da 'integral da esquerda leva à formulaçāo:

$$
\begin{aligned}
& \int_{v}\left(\sigma_{1,1,} u_{1}^{\prime}\right) d v=\int_{v}\left(\sigma_{1,} u_{i}^{\cdot}\right), d v-\int_{v} \sigma_{1,} u_{i, j}^{\cdot} d v= \\
& =\int_{S} T_{1} \dot{u}_{1} d S-\int_{V} \sigma_{1 j} \dot{\varepsilon}_{13} d V
\end{aligned}
$$

então:

$$
\int_{S} \mathrm{~T}_{i} \dot{\mathrm{u}}_{1} \mathrm{dS}+\int_{V} \mathrm{~F}_{1} \dot{\mathrm{u}}_{1} \mathrm{dV}=\int_{V} \rho \ddot{\mathrm{u}}_{i} \dot{\mathrm{u}}_{1} \mathrm{dV}+\int_{V} \sigma_{1,} \dot{\varepsilon}_{1\}} \mathrm{dV}
$$

(b) Balanço de energia durante a,extensão de uma trinca considere umã placa contendo uma trinca como mostra a figura 4.4 , então tem-se a seguinte expressão:

$$
\int_{\Gamma+\Gamma_{s}} T_{1} \frac{d u_{1}}{d l} d \Gamma+\iint_{A} F_{1} \frac{d u_{1}}{d l} d A=\iint_{A} \rho \ddot{u}_{1} \frac{d u_{1}}{d l} d A+
$$




$$
+\iint \sigma_{11} \frac{d \varepsilon_{11}}{d_{1}} d A+\hat{J}
$$

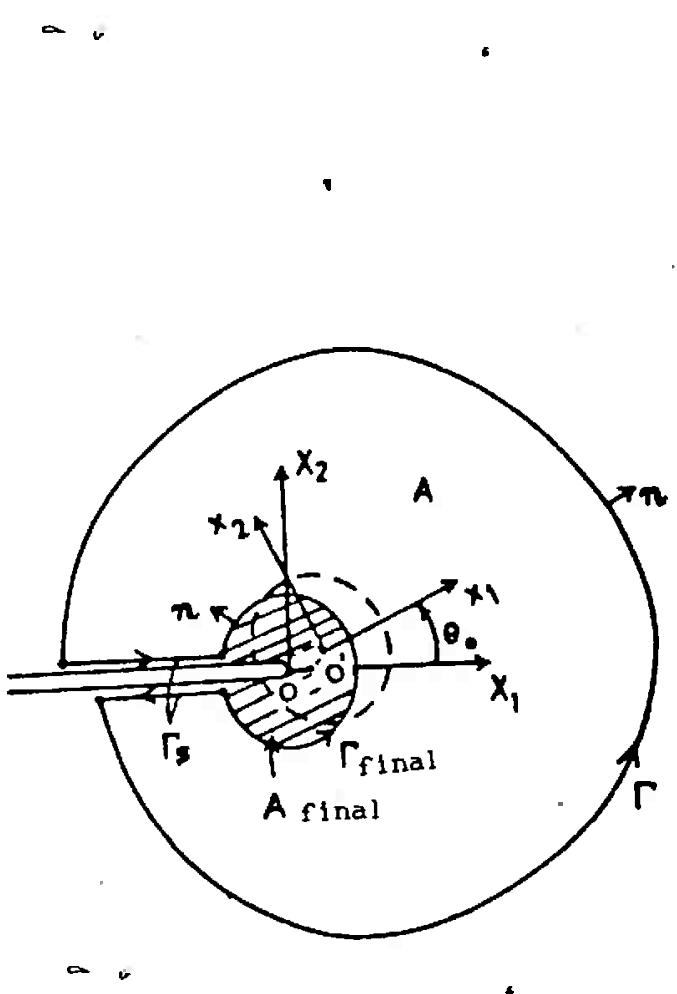

Figura 4.4 Representação geométrica da região de processo de fratura 
A taxa de variação de energia do material na região do processo de fratura é representada pela integral- $\hat{J}$, porque a fratura não pode ser caracterizada ainda dentro teoria da mecánica dos meios contínuos.

Usando o teorema de Gauss e a equação de moyimento 4.36, a equação 4.40 reduz-se a:

$$
\begin{gathered}
\hat{J}=\iint_{A}\left[\left(\sigma_{1,} \frac{\partial u_{1}}{\partial l}\right]_{, j}+\left(F_{1}-\rho \ddot{u}_{1}\right) \frac{d u_{1}}{d l}-\sigma_{1 j} \frac{d \varepsilon_{i j}}{d l}\right] d A+ \\
+\int_{\Gamma_{f 1 \text { nal }}} T_{1} \frac{d u_{1}}{d l} d \Gamma
\end{gathered}
$$

A transformação na fígura 4.4 , entre os sistemas de referências fixo e móvel é da forma:

$$
\begin{aligned}
& x_{1}=x_{1} \cos \theta_{0}+x_{2} \operatorname{sen} \theta_{2}-1 \\
& x_{2}=-x_{1} \operatorname{sen} \theta_{0}+x_{2} \cos \theta_{0}
\end{aligned}
$$

e os deslocamentos relativos, em termos da referência fixa 0 - $\mathrm{X}_{1}$, $\mathrm{x}_{2}$, são da forma:

$$
\begin{aligned}
U_{1}\left(x_{1}, x_{2}, x_{3}, 1\right) & =u_{1}\left(x_{1} \cos \theta_{0}+x_{2} \operatorname{sen} \theta_{2}-1,-x_{1} \operatorname{sen} \theta_{0}+\right. \\
& \left.+x_{2} \cos \theta_{0}, 1\right)
\end{aligned}
$$


e obtemos a seguinte rètação:

$$
\frac{d U_{1}}{d I}=\frac{\partial u_{1}}{\partial I}+\frac{\partial u_{1}}{\partial I}+\frac{\partial u_{1}}{\partial x_{1}} \frac{\partial x_{1}}{\partial I}=\frac{\partial u_{1}}{\partial I}-\frac{\partial u_{1}}{\partial x_{1}} 4.44
$$

A equação 4.44 , substituida em 4.41 , resulta:

$$
\hat{J}=\int_{\Gamma_{\text {fina }}} T_{1}\left(\frac{\partial u_{1}}{\partial l}-\frac{\partial u_{1}}{\partial x}\right) d \Gamma
$$

Na equação 4.45, nenhuma restrição foi imposta na relação tensão versus deformação do material, logo a integral- $\hat{J}$ pode ser a representação da taxa de liberação de energia de um material arbitrário durante a extensão de trincas.

De grande interesse neste trabalho é o tratamento do problema da extensão de trincas em configuraçōes tridimensionais é o caso apresentado na figura 4.5 .

KISHIMOTO ${ }^{29}$ demonstra que:

$$
\begin{aligned}
\hat{J}_{k}= & \int_{\Gamma+\Gamma-\Gamma} w_{e} n_{k} d \Gamma-\int_{\Gamma+\Gamma} T_{1} \frac{\partial u_{1}}{\partial x_{k}} d \Gamma+\iint_{A}\left\{\sigma_{1 j} \frac{\partial \varepsilon_{i j}^{*}}{\partial x_{k}}+\right. \\
& +\left(\rho \ddot{u}_{1}-F_{1}\right) \frac{\partial u_{1}}{\partial x_{k}}+\frac{\partial w_{e}}{\partial x_{1}} p_{1} p_{k}-\frac{\partial}{\partial x_{1}}\left(\sigma_{1 j} p_{j} \frac{\partial u_{1}}{\partial x_{1}} p_{1}\right\} d A \quad 4.46
\end{aligned}
$$

onde, $p_{1}$ representa o vétor normal à superficie de um elemento de placa, sendo $p_{j}$ o componente de $x_{j}$.

AOKI, KISHIMOTO e SAKATA $^{29}$ generalizaram a integral- $\hat{J}$ para os casos, além de translacional, os casos de rotacionalidae, de expansão auto-similar e distorcional, formando as integral- $\hat{\mathrm{L}}$, 
integral- $\hat{M}$ e a integral- $\hat{\mathrm{I}}$ respectivamente. As mesmas incluem os agora denominados casos especiais: integral-J de RICE $e$ a integral-I e integral-M de KNOWLES e STERNBERG.

o critério de fratura é constituido de tal.forma que se $\hat{J}_{c}$ for a taxa de energia dissipada na região de processo da fratura, correspondente ao crescimento de trincas por unidade de área, o critério de fratura em função do balanço de energia é dado por:

$$
\hat{J}=\hat{J}_{c}
$$

Postulando, de acordo com $\mathrm{BROBERG}^{30}$, que a região de processo da fratura é autônoma, no sentido de não depender da geometria do corpo ou das condições da trinca ou do carregamento, a região de processo é considerada de dimensões constantes movendo-se com a mesma velocidade que a ponta da trinca, de tal modo que a relação:

$$
\frac{\partial u_{1}}{\partial l}=0, \quad \text { sobre } \Gamma_{\text {final }}
$$

e a equação final, obtida da equação 4.45 é dada por:

$$
\hat{J}=-\int_{\Gamma_{\text {final }}} \quad T_{1} \frac{\partial u_{1}}{\partial x_{1}} d \Gamma
$$




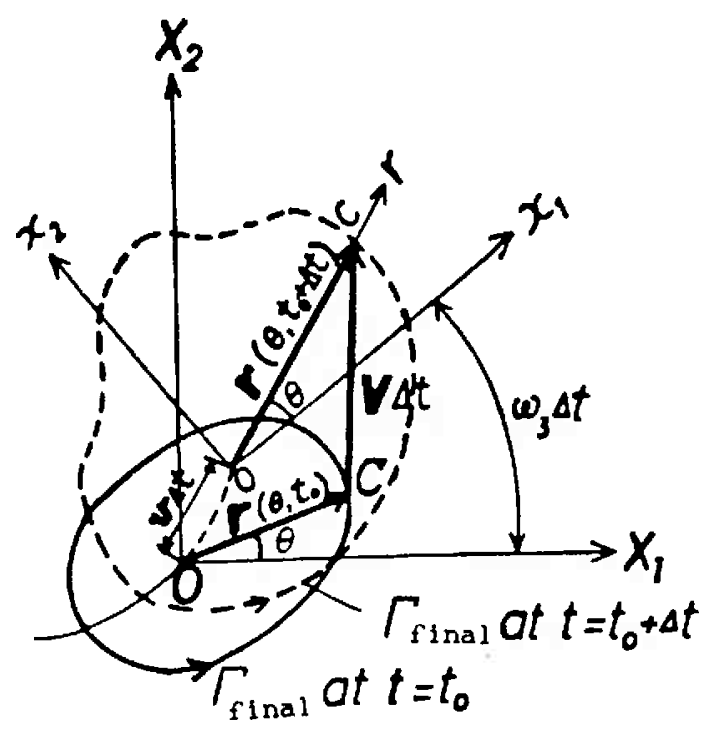

(a)

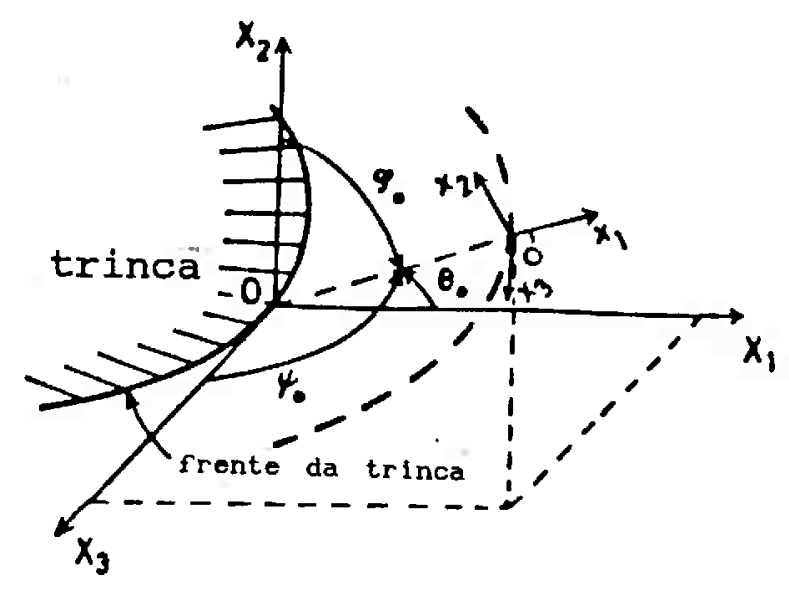

(b)

Figura 4.5 Representação esquemática de trinca 3D ,KISHIMOTO ${ }^{28}$ a) definição da velocidade $\underline{v}$ da frente da trinca $\Gamma_{\text {final }}$

b) representação da frente da trinca 
AOKI, KISHIMOTO e SAKATA $^{32}$ formalizaram, em 1984, as expressões gerais do fluxo de energia para 0 interior de uma região de processo deocorrência de problemas de fratura elasto-plástica, considerando nas análises os mais generalizados casos tridimensionais.

A figura 4.6 mostra a configuração tridimensional para 0 problema de trinca em 3-D. A curva sólida representa 'o contorno da frente da trinca no estado incial, a tracejada é sua frente atual após uma extensão infinitesimal. seja $0-x_{1} x_{2} x_{3} \circ$ sistema de referência com a origem em 0 , sendo 0 um ponto arbitrário na curva da frente da trinca; sejam $\underline{N}$, $B_{-} e \underline{T}$ os vetores normal, binormal e tangencial respectivamente, e todos localizados no ponto $0 ;$ a interseç̧ão da curva tracejada com o plano determinado por $\underline{N}$ e $\underline{B}$, define o ponto o. Assim, os vetores $\underline{\mathbf{n}}, \underline{b}$ e $\underline{t}$ são respectivamente, normàl, binormal e tangencial da nova frente da trinca representada pela curva tracejada. Os vetores $\underline{n}, \underline{b}$ e $\underline{t}$ são obtidos por translação e rotação dos vetores unitários $\underline{N}$, $\underline{B}$ e com a frente da trinca movimentando-se a uma velocidade linear $\underline{v}$ e angular $\omega$.

Considerando-se um disco fino que inclua 0 ; ponto 0 e ao mesmo corta a região do processo de fratura por plaṇps paralelos ao plano determinado pelos vetores $\underline{N}$ e $\underline{B}$. A espessura, o volume e - contorno do disco são representados por $\Delta \lambda, \Delta V_{\text {final }}$ e $\Gamma_{\text {flnal }}$ respectivamente. Considera-se também o volume do material que envolve a frente da trinca na forma de um toróide de.revolução. $S$ é a superficie externà "de $V$ como mostra a figura 4.7 . 

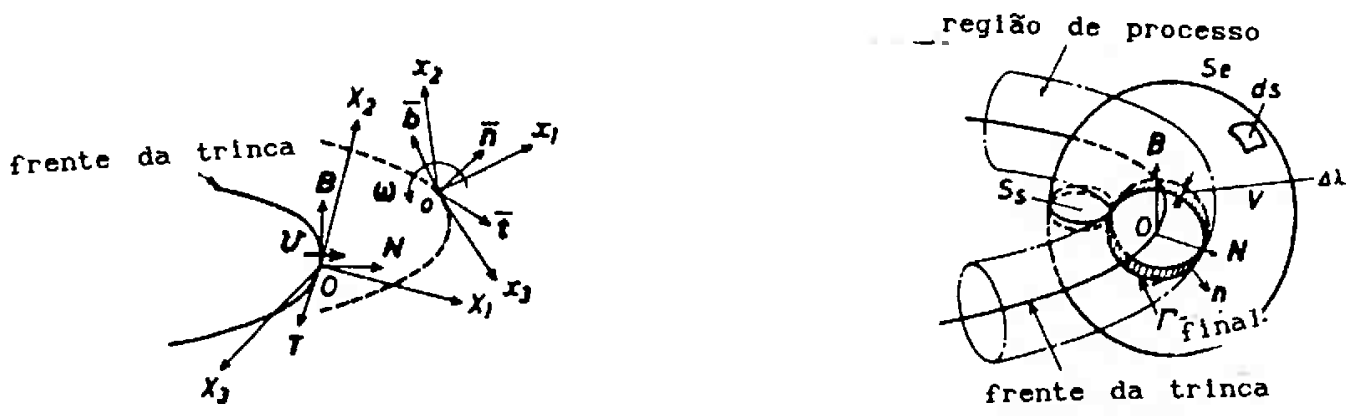

Figura 4.6 - Representação tridimensional de um problema de extensão de trinca. AOKI ${ }^{31}$ e colaboradores. 


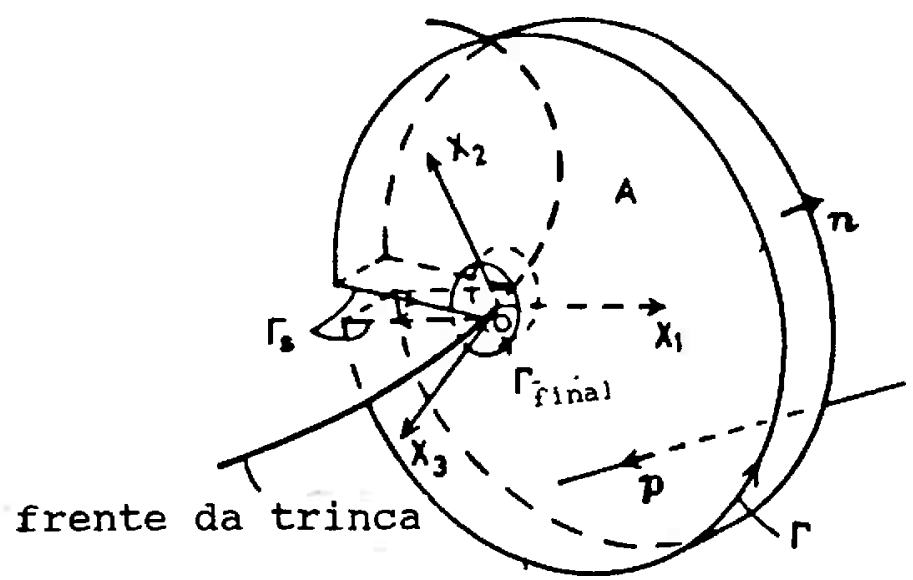

$+$
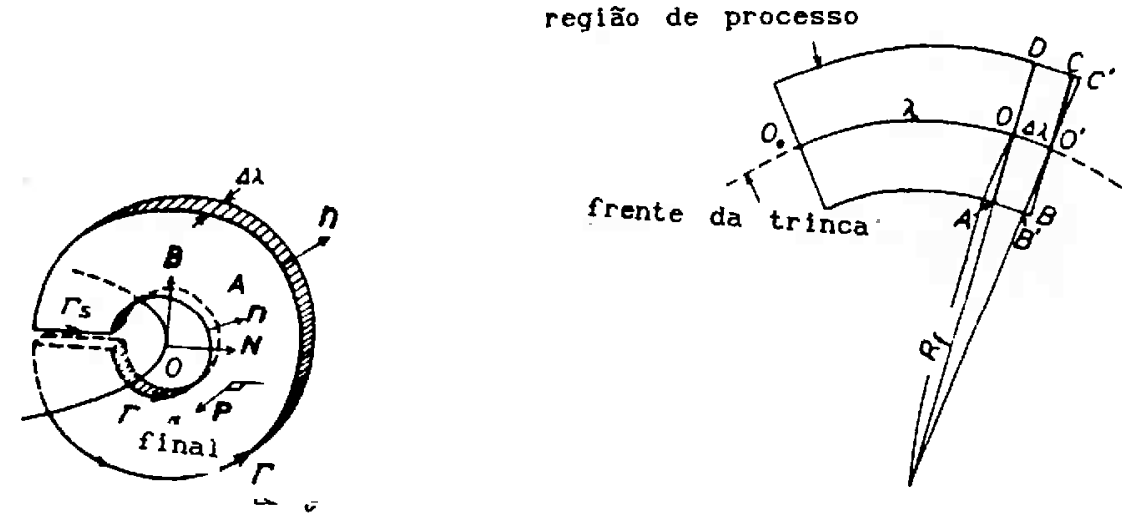

Figura 4.7 - Configuração da frente de uma trinca e o volume para integração. AOKI $^{31}$ e colaboradores. 
Considerando o balanço de energia no material de volume $\mathrm{V}$ e fazendo $\Delta \lambda \rightarrow 0$, obtém-se o fluxo local da energia total por unidades de comprimento de $\Delta \lambda$ e de espessura, na forma de:

$$
\Phi=v_{k} \hat{J}_{x}+\omega_{k} \hat{L}_{k}+a \hat{M}+\hat{I}
$$

sendo $\hat{J}_{k}, \hat{L}_{k}, \hat{M}$ e $\hat{I}_{\text {, dados em }} A_{0 K I^{29}}$ e colaboradores nas seguintes formas :

$$
\begin{aligned}
& \cdot \hat{J}_{k}=\int \Gamma_{\text {final }} \rho(\mathrm{K}+e) \mathrm{n}_{\mathrm{k}} \mathrm{d} \Gamma-\iint_{\mathrm{S}_{e}+\mathrm{Ss}_{\mathrm{s}}} \mathrm{T}_{1} \frac{\partial \mathrm{u}_{1}}{\partial \mathrm{x}_{\mathrm{x}}} \mathrm{ds}+ \\
& +\iiint_{V}\left\{\sigma_{1,} \frac{\partial \varepsilon_{1,}}{\partial x_{k}} d s+\left(\rho \ddot{u}_{1}-F_{1}\right) \frac{\partial u_{1}}{\partial x_{k}}\right\} d V \\
& \hat{\mathrm{L}}=\int \Gamma_{\text {final }} \epsilon_{i \alpha 1} \rho(\mathrm{K}+\mathrm{e}) \mathrm{x}_{1} \mathrm{n}_{1} \mathrm{~d} \Gamma-\iint_{\mathrm{Se}_{\mathrm{e}}+\mathrm{S}_{\mathrm{s}}} \epsilon_{i k 1} \mathrm{x}_{1} \mathrm{~T}_{j} \frac{\partial \mathrm{u}_{j}}{\partial \mathrm{u}_{1}} \mathrm{dS}+ \\
& +\iiint_{V} \epsilon_{1 \alpha 1}\left\{\sigma_{j 1} \frac{\partial u_{j}}{\partial x_{1}}+X_{1}\left(\rho \ddot{u}_{3}-F_{j}\right) \frac{\partial u_{j}}{\partial x_{1}}+\right. \\
& \left.+x_{1} \sigma_{j k} \frac{\partial \varepsilon_{j k}}{\partial X_{1}}\right\} d V
\end{aligned}
$$




$$
\begin{aligned}
& \hat{\mathrm{M}}=\int_{\Gamma_{\text {rinal }}}\left\{\rho(\mathrm{K}+\mathrm{e}) \mathrm{n}_{1} \mathrm{X}_{1} \mathrm{~d} \Gamma-\iint_{\mathrm{S}_{0}+\mathrm{Sa}_{\mathrm{s}}}\left(\mathrm{X}_{j} \mathrm{~T}_{,} \frac{\partial \mathrm{u}_{j}}{\partial \mathrm{x}_{1}}\right) \mathrm{dS}+\right. \\
& +\iiint_{V}\left\{\sigma_{1,} \varepsilon_{1 j}+\sigma_{13} \frac{\partial \varepsilon_{1 j}}{\partial x_{1}} x_{1}+\left(\rho \ddot{u}_{j}-F_{j}\right) \frac{\partial u_{j}}{\partial x_{1}}\right\} d V \quad 4.52
\end{aligned}
$$

onde:

K: energia cinética por unidáde de massa

e: energia interna por unidade de massa

Seja $\Delta E$ a taxa da energia total transferida no tempo,

então:

$$
E=\int_{0}^{\lambda} \Phi^{*} d \lambda
$$

para:

$$
\Phi^{*}=\lim _{\Delta \lambda \rightarrow 0} \frac{\Delta E}{\Delta \lambda}=\frac{\mathrm{d} E}{\mathrm{~d} \lambda}
$$

$\mathrm{Na}$ expressãó 4.54 , os valores de $\Phi^{*}$ são dados pela equação 4.49 , por unidade de espessura.

Uma analogia poderá ser feita para o caso bidimensional da integral-J de RICE, onde FREUND ${ }^{32}$ mostra que:

$$
J=G=\frac{1-v^{2}}{E}\left[K_{I}^{2}+K_{I I}^{2}\right]
$$

G é a taxa de liberação de energia de IRWIN para trinca crescendo coplanarmente. A fórmula 4.55 é válida apenas para o caso elástico, podendo incluir uma pequena contribuição de plasticidade na ponta da trinca. - . 


\section{REFERENCIAS BIBLIOGRAFICAS - Capitulo}

1. BRUST JR, F.W. The use of new path independent integrals in elastic-plastic and creep fracture. PhD Thesis, Georgia Institute of Technology, Nov. 1984.

2. JENNER, $A$. and DODD, B. cold upsetting and free surface ductility. Journal of Mechanical Working Technology, 5:31-43, 1981.

3. BATES, R.C. Mechanics and mechanisms of fracture. In: TIEN, J.K. and ELLIOTT, J.F. (eds.) The Metallurgical Treatise. Presentations at the USA-China Bilateral Conference sponsered by the Metallurgical society of the AIME The American Society for Metals and Chinese society of Metals, AIME, New York, 1981. pp. 551-570

4. KANNINEN, M.F. and POPELAR, C.H. Advanced Fracture Mechanics. Clarendon, Oxford University, 1985. pp.281-391

5. DUGDALE, D.S. Yielding zones in cracked sheets containing slits. Journal of the Mechanics and Physics of Solids, $8: 100-108,1960$.

6. BROEK, D. Elementary Engineering Fracture Mechaniçs. 3.ed. The Hague, Martinus Nighhoff, 1982.

7. WILSDORF, H. G. - Fw The ductile fracture of. metals: a microstructural view point. Materials science and Engineering. 59:1-39, 1983 .

8. ZHUANG, T. On Elastic-plastic Fracture Criterion, PhD dissertation, Syracuse University, Aug.1984. pp.8-41.

9. Op. cit., Referência 4, chapter 3 - Linear Elastic Fracture Mechanics, pp. 138-191.

10. GRIFFITH, A.A. The phenomenon of rupture and flow of solids. 
Philosophical Transactions of Royal Society, London, 221A: 163-198, 1920.

11. SACK, R.A. Procedings of Physical Society of London. 58:729, 1946.

12. INGLIS, C.E. Stress in a plate due to the presence of cracks and sharp corners. Transactions of the Institute of Naval Archictets. 60:219-230, 1913 .

13. MOTT, N.F. Engineering. 165:16, 1948.

14. OROWAN,E. EnergY criteria of fracture. Welding Research Supplement, 20:1575-1605, 1955.

15. WILLIANS, M.L. On the stress distribution at the base of a stationary crack. Transactions of the ASME Journal of Applied Mechanics, 24:109-114, 1957.

16. IRWIN, G.C. Analysis of stresses and strains near the end of a crack tranversing a plate. Transactions of the ASME Journal of Applied Mechanics. 24:361-364, 1957.

17. ERDOGAN, F. Stress intensity factor. Transactions of the ASME - Journal of Applied Mechanics, 50:992-1002, 1983.

18. SANDERS, J.L. On the Griffith - Irwin fracture theory. Transactions of the ASME - Journal of Applied.Mechanics, 27 (2):352-353, 1960 .

19. ESHELBY, J.D. The coninum theory of lattice defects In: SEITZ, F. and TURNBULL, D. Solid state Physics. New York, Academic Press, 1956. vol.III, pp.79-144.

20. CHEREPANOV,G.P. Crack propagation in continuous media. Journal of Applied Mathematics and Mechanics. English translation of the Soviet Journal PMM, 31(3):504-512, 1967.

21. RICE, J.R. A path independent integral and the approximated 
analysis of strain concentration by notches and cracks.Transactions of the ASME - Journal of Applied Mechanics, 35(2):379-386, 1968.

22. DIETER, G. E. Mechanical Metallurgy. 2.ed. New York, McGraw$-H i 11,1976$. pp. 277-280

23. NOETHER, R. Invariante Variations Probleme Göttinger Nachrichten, Mathematisch. Physikalische Klasse, 2:235-257, 1918.

24. CUSHING, J.T. Applied Analytical, Mathematics for Physical Scientists. New York, John Wiley, 1975. pp.251-257

25. HERRMANN, A.G. On the conservation laws of continuum mechanics. International Journal of solids and structures. $\underline{17}(8): 1-9,1981$.

26. KNOWLES, J.K. and STERNBERG, E. On a classe of conservation laws in linearized and finite elastostatics. Archive for Rational Mechanics and Analysis, 44(3):187-211, 1972.

27. BUDIANSKY, $B$ and RICE, J.R. Conservation laws and energY-realease rates. Transactions of the ASME - Journal of Applied Mechanics, 40:201-203, Mar.1973.

28. KISHIMOTO, $\mathrm{K}$; $A O K{ }_{\alpha} \mathrm{S}$. and SAKATA, M. On the path independent integral - $\hat{J}$. Engineering Fracture Mechanics, 13:841-850, 1980.

29. AOKI, S.; KISHIMOTO, K. and SAKATA, M. EnergY-release rate in elastic-plastic fracture problems. Transactions of the ASME - Journal of Applied Mechanics, 48:825-826, 1981.

30. BROBERG, K.B. Energy methods in statics and dynamics of fracture. Journal of Japan society for strength, Fracture and Materials, $10(2): 33-45,1975$. 
31. AOKI, S.; KISHIMOTO, K. and SAKATA, M. Energy flux into process region in elastic-plastic fracture problems. Engineering Fracture Mechanics, 19(5):827-836, 1984 .

32. FREUND, L.B. Stress intensity factor calculations based on a conservative integral. International Journal of solids and Structures, 14:241-250, 1976 . 


\section{CONFORMabilidade PLAstica dos metais PELA MECANica dA Fratura NAO-LINEAR}

\subsection{Conceitos de Conformabilidade Plástica dos Metais}

A conformabìlidade plástica, dos metais é definida no "Metals Handbook", segundo DIETER", como sendoa; facilidade relativa com que um material metálico possa ser conformado de deformação plástica. Essa definição, mesmo sendo ampla,é de natureza qualitativa. DIETER propôs um outro conceito de conformabilidade: é o grau de deformação que possa ser alcançado em um processo especifico de conformação plástica sẹm a criação de condições indesejáveis, como o surgimento de'.trincas ou fraturas, o péssimo acabamento superficial da peça, a formação de ondulações ou rugas, a falta de enchimento na matriz de conformação e outras.

A conformabilidade é, por sua vez, dependente das condições locais das distribuições de tensão, de deformação, de taxas de deformação e de temperáturas. Todas essas distribuições que combinadas com a resistência básica dos materiais metálicos, podem levar à ocorrência de fratura dúctil.

5.1.1. Conformabilidade Baseada no Conceito Microscópico da Fratura Dúctil

A idéia amplamente aceitável do conceito de fratura dúctil, em OSAKADA e MORI ${ }^{2}$, é aquela que observada por técnicas metalográficas ocorre fortemente dependente da micrọestrutura do material metálico e obsęrvando a seguinte seqüência: 
a) formação do núcleo de uma trinca pelo crescimento de cavidades ou vazios em torno de inclusões ou particulas de segunda fase, após uma determinada quantidade de deformação plástica;

b) Crescimento do núcleo da trinca, pela continuidade da deformação plástica;

c) Coalescência ou crescimento rápido do núcleo da trinca para a formação de uma fratura ḿacroscópica provocada por uma excessiva concentração de tensão em uma pequena região do material metálico;

Diversos pesquisadores desenvolveram critérios de fratura dúctil baseados nos mais diversos mecanismos, entre os quais ZAVAGLIA ${ }^{3}$ que baseada no trabalho de VINH $^{4}$ relacionou os seguintes:

a) modelo do crescimento e coalescencia de vazios de MCCLINTOCK $^{5}$, THOMASON ${ }^{6}$, e RICE-TRACEY ${ }^{7}$;

b) modelo do crescimento de vazios em torno de partículas de ARGON-IN-SAFLOGU ${ }^{8}$;

c) modelo probabilístico e microestrutural da deformação dúctil de HADDAD-SOWERBY ${ }^{9}$;

d) modelo do patencial plástico de $\operatorname{RICE}^{10}$ e $\operatorname{GURSON}^{12}$;

e) modelo da aproximação estatistica.. de SEAMAN-CURRAN-SHOCKEY $\stackrel{12}{\text { ? }}$

A ductilidade de um material metálico é expressa como sendo a máxima deformação alcançada em um corpo de prova 
padronizado antes da rocorrencia da fratura e é definida em função da redução de área desse corpo de prova, na forma:

$$
\varepsilon_{0}=\frac{\mathrm{RA}}{1-\mathrm{RA}}
$$

para

$$
R A=\frac{A_{0}-A_{f}}{A_{0}}
$$

$A_{0}$ e $A_{r}$ são respectivamente as áreas inicial e final do corpo de prova.

A ductilidade assim definida refere-se apenas à capacidade do material sofrer grande deformação plástica, e a mesma é útil na escôlha do material a ser processado. Já a conformabilidade diz respeito ao grau de severidade com que o material sofre conformacão plástica sem a ocorrência de defeitos.

5.1.2. Conformabilidade Baseada no Conceito Macroscópico de Deformação Plástica

A necessidade da quantificação da conformabilidade levou vários pesquisadores a proporem diversos critérios e a maioria desses baseados em experiências laboratoriais, cujo ob̈jetivo maior era o de construir modelos macroscópicos ou fenomenológicos . Os principais critérios de conformabilidade são dẹscritos por ZAVAGLIA ${ }^{3}$, entre os quais citaremos os seguintes:

a) modelo das curvas limite de conformação de $\operatorname{KEELER}^{13}$;

b) critério de VON MISES da plasticidade dos metais, limitado por uma tensão efetiva máxima de resistência, em ALTAN $^{14}$ e colaboradores; 
c) critério de TRESCA do escoamento plástico, limitado por uma tensão efetiva máxima de cisalhamento, em ALTAN $^{14} e$ colaboradores;

d) critérios análogos à máxima energia de deformação de: COCKCRFT e LATHAN ${ }^{15}$, GILLEMOT ${ }^{16}$, OH-CHENeKOBAYASHI ${ }^{17}$ e critério modificado de zAVAGLIA ${ }^{3}$;

e) critério da tensão hidrostática e da porcentagem de vazios de SEKIGUSHI-OSAKADA-HAYASHI ${ }^{18}$.

\subsubsection{Desvantagens e Vantagens dos Critérios de Conformabilidade Variantes: baseados na fratura dưctil e na deformação plástica dos metais}

A construção dos critérios de conformabilidade variantes, os que não "são baseados ṇo teorema dé NOETHER das integrais invariantes, é bastante dependente de várịas variáveis que deverão ser, de alguma forma, controladas durante e após a realização dos ensaios. Essas principais variáveis são a natureza e composição das ligas metálicas, impurezas presentẹs na forma de inclusões e partículas de segunda fase (tamanho, forma e porcentagem, , estado de tensão a que foi submetido o corpo de prova, temperatura da realização do ensaio, características microestruturais de tamanho de grãos, efeitos dos tratamentos térmicos, e outros. Nessas condições, ter-se-á que realizar um número elevado de ensaios sob condições controladas pạara se obter um critério válido. a .

As três principais vantagens neste 'critério de conformabilidade são: 
a) a possibilidade do estudo sistemático dos mecanismos de fratura dúctil;

b) é possibilidade, após o conhecimento dos mecanismos de fratura dúctil, da elaboração de fórmulas ainaliticas do tipo fechada;

c) é conseqüência da primeira e consiste no tratamento numérico do problema modelado em computadores ou calculadoras.

As desvantagens dos critérios baseados na deformação plástica estão estritamente ligadas às limitações da teoria geral da plasticidade que é utilizada através de várias técnicas ,principalmente as numérica pelo método dos elementos finitos, para a obtenção da distribuição de tensōes e de dẹormações no corpo sólido. Além do mais, deve-se conhecer as condições de atrito nas interfaces peça-ferramenta que, por sua vez, necessita de uma boa modelagem. Alguns problemas de tensão uniforme têm sido bem analisados por esse critério, como exemplo a trefilação de fios, a estampagem de chapas, 0 ,dobramento de chapas e perfís, a extrusão e alguns casos de forjamento em matriz plana. os resultados dos ensaios, obtidos por esses critérios de conformabilidade são de natureza tecnológica, ou seja, os valores numéricos obtidos estão relacionados à processos de conformação, que cujos valores quando postos num diagrama fornecem um mapa de conformabilidade.

Uma variante do critério é a construção experimental de mapas de deformações de fratura, em que podem ser insciritos vários 
processos limitados a uma curva limite de conformabilidade. Esse diagrama é denominado de Curva Limite de conformabilidade.

As vantagens são, obviamente, o uso tecnológico desses diagramas de Curva Limite de conformabilidade na prática industrial.

5.2. Campos de Elasto-Plasticidade Gerados por Integrais Invariantes da Mecânica da Fratura Não-Linear

Quando o comportamento plástico de um material metálico, representado pela deformação, plástica de encrụamento, for caracterizado pela lei de potência de HOLLOMON ${ }^{19}$, a singularidade dominante será denominada de modelo HRR, em homenagem aos pesquisadores HUTCHINSON ${ }^{20}$, RICE e ROSENGREN ${ }^{21}$. Enquanto que se a singularidade for caracterizada por pequenas deformações, a não-linearidade entra no estudo através de relações elasto-plásticas.

A curva do estado uniaxial de tensão versus deformação experimental é modelada pela relação de RAMBERG-OSGOOD ${ }^{22}$ :

$$
\frac{\varepsilon}{\varepsilon_{0}}=\frac{\sigma}{\sigma_{0}}+\alpha\left(\frac{\sigma}{\sigma_{0}}\right)^{\mathrm{n}}
$$

onde:

$$
\begin{aligned}
& \varepsilon_{0}: \text { é a deformação de escoamento plástico } \\
& \sigma: \text { é a tensão limite de escoamento plástico } \\
& n>1: \text { é o expoente de encurvamento } \\
& \alpha: \text { é uma constante material } \\
& \quad \text { Quando } n \text { tender para o infinito, o comportamento do }
\end{aligned}
$$


material metálico é o de um elástico-perfeitamente plástico.

A equação 5.3 é aplicável para uma tensão monotônica crescente a qual não acomoda um descarregamento elástico.

Na zona plástica envolvendo a ponta da trinca aplica-se a teoria da deformação plástica de HENCKY-YLYUSHIN-NADAI ${ }^{23}$ e as condições da teoria da plasticidade, para um processo independente da pressão hidrostática:

$$
\mathrm{P}_{\mathrm{H}}=\sigma_{\mathrm{kk} / 3}
$$

5.4

são dadas pelas relação tensão versus deformação da forma:

$$
\varepsilon_{i j}=\frac{1+\nu}{E} s_{1 j}+\frac{1-2 v}{3 E} \sigma_{k k} \delta_{1 j}+\frac{3 \bar{\varepsilon}^{p}}{2 \bar{\sigma}} s_{1 j}:
$$

onde os componentes das tensões reduzidas são dados por:

$$
S_{1 j}=\sigma_{1 j}^{\prime}=\sigma_{1 j}-\frac{1}{3} \sigma_{k k} \delta_{1 j}
$$

A tensão e deformação efetivas, baseadas no critério de VON MISES, são dadas por:

$$
\bar{\sigma}=\left(3 J_{2}\right)^{1 / 2}=\left(3 / 2 S_{1 j} S_{1 j}\right)^{1 / 2}
$$

e

$$
\bar{\varepsilon}^{p}=\frac{2}{3} \varepsilon_{1 j}^{p} \varepsilon_{1 j}^{p}
$$

sendo $\mathrm{J}_{2}$, o segundo invariante do tensor das tensões reduzidas. 
A tensão e a deformação efetivas estão relacionadas pela forma de RAMBERG-OSGOOD:

$$
\bar{\varepsilon}_{0}^{\mathrm{p}}=\alpha \varepsilon\left(\frac{\bar{\sigma}}{\sigma_{0}}\right)^{\mathrm{n}}
$$

A relação geneneralizada entre tensões e deformações é então da forma:

$$
\varepsilon_{1\}}=\frac{1+D}{E} s_{1 j}+\frac{1-2 D}{3 E} \sigma_{k k} \delta_{1 j}+\frac{3}{2} \alpha \varepsilon_{0}\left(\frac{\sigma}{\sigma_{0}}\right)^{n-1} \times \frac{S_{1 j}}{\sigma_{0}^{\prime}}
$$

Como é esperada uma singularidade na ponta dà trinca, as deformações plásticas serão muito maiores que as respectivas elásticas estas serão desprezadas nas análises e dentro da região na vizinhança da ponta da trinca, figura 5.1; a equação 5.8 fica na forma:

$$
\varepsilon_{1 J}=\frac{3}{2} \alpha \varepsilon_{0}\left(\frac{\sigma}{\sigma_{0}}\right)^{n-1 \cdot} \frac{s_{1 J}}{\sigma_{0}}
$$

De acordo com o trabalho de RICE, para apenas uma singularidade existente na região associada com a ponta da trinca, existe um caminho circular $\Gamma$, de raio $r$ menor que $D$, envolvendo a trinca, figura 5.1, representada pela fórmula da integral-J de RICE por:

$$
J=r \int_{-\pi}^{\pi}\left\{W[\varepsilon(r, \theta)] \cos \theta-T_{1}(r, \theta) \frac{\partial u_{1}}{\partial x_{1}}(r, \theta)\right\} d \theta
$$


A teoria da deformação da plasticidade é vista como uma teoria não-linear da elasticidade, logo, a equação 5.10 da integral-J é independente do caminho e é tambem invariante.

como os termos na integração são basicamente produtos de componentes do tipo déformação e tensão, então ạ expressão seguinte é representativa dos fenômenos que ocorrem na região de processo, representada pela parte interna do círculo de raio $r$ menor que $D$ da figura 5.1:

$$
\lim _{r \rightarrow 0} \sigma_{1 j} \varepsilon_{1 j} \rightarrow \frac{f(\theta)}{r}
$$

ou seja, as variáveis podem ser separadas em funções de $\theta$ e $r$ apenas. 


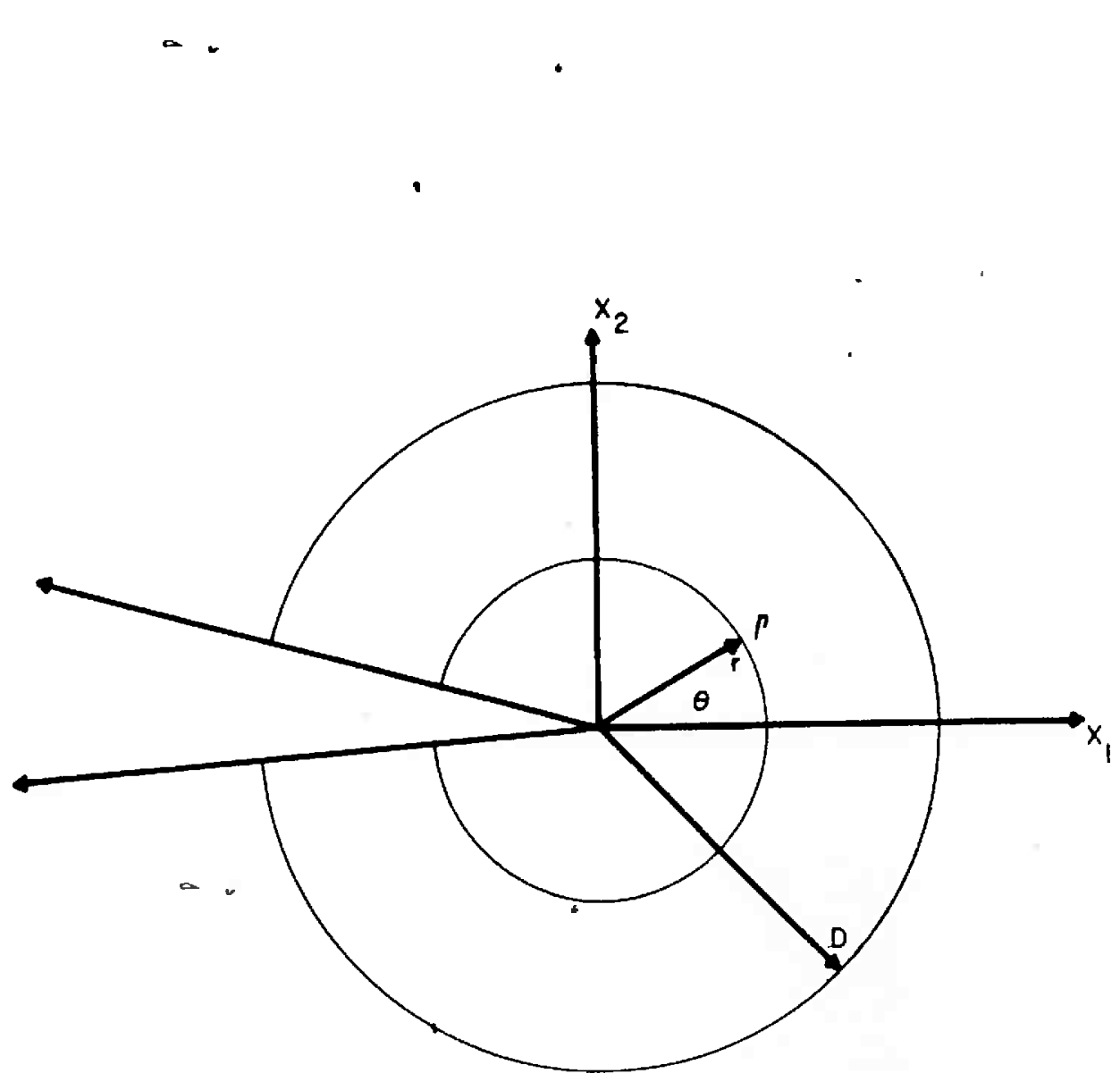

Figura 5.1 Sistema de coordenadas na ponta de uma trinca em 2D 


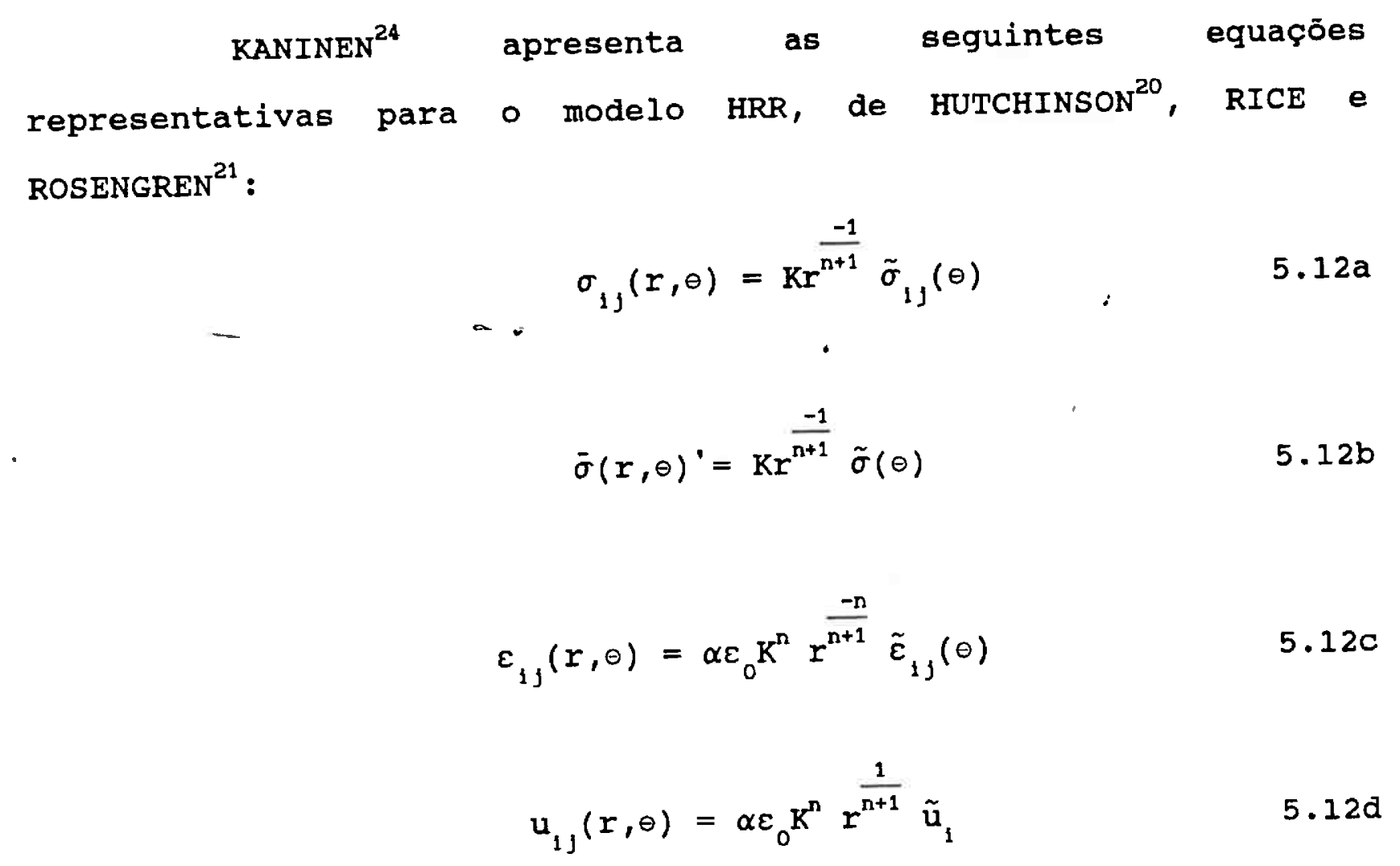

onde $\mathrm{K}$ é uma constante a ser determinada analiticamente.

Para o modo I de fratura, figura 4.3 , as equações 5.12 fornecem as formas das singularidades na ponta da trinca $e$ a dependência de $\ominus$ deve ser dẹterminada com $\circ$ objetivo de estabelecer a estrutura dos campos de tensão e de deformação na ponta da trinca. Isso resolve-se pela introdução da função de AIRY $\psi$ na sua forma assintótica:

$$
\psi=\operatorname{Kr}^{\left(\frac{2 n+1}{n+1}\right)} \Psi(\ominus)
$$

devendo satisfazer as condições de equilíbrio:

$$
\frac{\partial \sigma_{r r}}{\partial r}+\frac{1}{r} \frac{\partial \tau_{r \Theta}}{\partial \theta}+\frac{\sigma_{r r}-\sigma_{\Theta \Theta}}{r}+f_{r}=0
$$




$$
\frac{1}{r} \frac{\partial \sigma_{\theta \theta}}{\partial \theta}+\frac{\partial \tau_{r \theta}}{\partial r}+\frac{2 \tau_{r \theta}}{r}+f_{r}
$$

e também satisfazer a condição de compatibilidade:

$$
\frac{1}{r} \frac{\partial^{2}}{\partial r^{2}}\left(r \varepsilon_{\theta \theta}\right)+\frac{1}{r^{2}} \frac{\partial^{2} \varepsilon_{r r}}{\partial \theta^{2}}-\frac{1}{r} \frac{\partial \varepsilon_{r r}}{\partial r}-\frac{2 \partial}{r^{2} \partial r}\left(r \frac{\partial \varepsilon_{r \theta}}{\partial \theta}\right)=0 \quad 5.15
$$

sendo as tensões perto da trinca da forma:

$$
\begin{gathered}
\sigma_{\theta \theta}=\frac{\partial^{2} \psi}{\partial r^{2}}=\mathrm{Ks}(s-1) r^{\frac{-1}{n+1}} \tilde{\psi}^{\prime}(\theta) \\
\sigma_{r \theta}=-\frac{\partial}{\partial r}\left(\frac{1}{r} \frac{\partial \psi}{-\partial \theta}\right)=\mathrm{K}(1-s) r^{\frac{-1}{n+1}} \tilde{\psi}^{\prime}(\theta) \\
\sigma_{r r}=\frac{1}{r} \frac{\partial \psi}{\partial r}+\frac{1}{r^{2}} \frac{\partial^{2} \psi}{\partial \theta^{2}}=\operatorname{Kr}^{\frac{-1}{n+1}}\left[s \psi(\theta)+\psi^{\prime} \prime(\theta)\right]
\end{gathered}
$$

Na deformação plana $\sigma_{33}=\frac{\sigma_{r r t} \sigma_{\ominus \Theta}}{2}$ e a teṇsão efetiva na ponta da trinca é:

$$
\begin{gathered}
\bar{\sigma}=\left[\frac{3}{4}\left(\sigma_{r r}-\dot{\sigma}_{\ominus \theta}\right)^{2}+3 \sigma_{r \theta}^{2}\right]^{1 / 2}= \\
=\mathrm{Kr}^{\frac{-1}{\mathrm{n}+1}}\left\{\frac{3}{4}\left[\bar{\psi}^{\prime \prime}-s^{2} \bar{\psi}\right]+3\left[(1-s) \psi^{\prime}\right]^{2}\right)^{1 / 2}
\end{gathered}
$$

para $s=\left(\frac{2 n+1}{n+1}\right)$.

Substituindo as equações 5.16 e 5.17 em 5.12 , para a obtenção dos componentes de deformação na equação 5.15 , o seguinte resultado é 
obtido para o caso de deformação plana:

$$
\left[\frac{d^{2}}{d \theta^{2}}+\left(\frac{n}{n+1}\right)\left(\frac{n+2}{n+1}\right)\right]\left[\tilde{\sigma}^{n-1}\left(\tilde{\psi}^{\prime \prime}+\frac{2 n+1}{(n+1)^{2}} \psi\right)\right]+\frac{4 n}{(n+1)^{2}}\left(\tilde{\sigma}^{n-1} \psi^{\prime}\right)=0 \quad 5.18
$$

Um tratamento similar para o estado plano de tensão fornece:

$$
\begin{gathered}
{\left[\frac{d^{2}}{d \theta^{2}}+\frac{n}{n+1}\right]\left[\tilde{\sigma}^{n-1}\left(2 \tilde{\psi}^{\prime \prime}+\left(\frac{n+2}{n+1}\right)\left(\frac{2 n+1}{n+1}\right) \tilde{\psi}\right]+\right.} \\
+\frac{n}{(n+1)^{2}} \tilde{\sigma}^{n-1}\left[\tilde{\psi}^{\prime \prime}+\left(\frac{n-1}{n+1}\right)\left(\frac{2 n+1}{n+1}\right) \tilde{\psi}\right]+\cdots \\
+\frac{6 n}{(n+1)^{2}}\left(\tilde{\sigma}^{n-1} \tilde{\psi}^{\prime}\right)^{\prime}=0
\end{gathered}
$$

Para o estado plano de tensão:

$$
\begin{gathered}
\tilde{\sigma}(\theta)=\left\{\tilde{\sigma}_{r r}^{2}+\tilde{\sigma}_{\theta \Theta}^{2}-\tilde{\sigma}_{r r} \tilde{\sigma}_{\theta \theta}+3 \tilde{\sigma}_{r \theta}^{2}\right\}^{1 / 2}= \\
=\left\{\left[\tilde{\psi}^{\prime \prime}+s \tilde{\psi}\right]^{2}+[s(s-1) \tilde{\psi}]^{2}-s(s-1)\left[\tilde{\psi}^{\prime \prime}+s \tilde{\psi}\right] \tilde{\psi}+\right. \\
\left.+3\left[(1-s) \psi^{\prime}\right]^{2}\right\}^{1 / 2}
\end{gathered}
$$

na equação 5.16 , a condição $\sigma_{\theta \theta}=\sigma_{r \theta}$ para $\theta= \pm \pi$, requer:

$$
\tilde{\psi}( \pm \pi)=\psi^{\prime}( \pm \pi)=0
$$

Para o modo da abertura da trinca, $\psi$ é simétrica em relação a 
$\theta=0$ e $\theta=-\pi$, e nesse caso tem-se:

$$
\psi^{\prime}(\theta)=\psi^{\prime \prime \prime}=0
$$

-Em 5.18 e 5.19 tem-se as equaçōes diferenciais ordinárias homogêneas, com condições homogêneas e as equações 5.21 e 5.22 definem 0 problema de dois valores de fronteiras. É na realidade um problema de autovalor não linear, no qual o expoente de $r$ é o autovalor.

$\dot{E}$ grande a dificuldade de resolver as equações $5.19 \mathrm{e}$ 5.20 por integração analitica, mas as mesmas foram resolvidas numericamente, considerando o problema do tipo de valor inicial.

Considerando um valor especifico para $\tilde{\psi}^{\prime \prime \prime}(0)$, a integração numérica é desenvolvida usando o método de RUNGE-KUTTA, descrito em $\mathrm{BLUM}^{25}$.

A função característica é normalizada pela seguinte forma:

$$
\begin{gathered}
\tilde{\sigma}_{\text {max }}=\sigma_{0} \\
\varepsilon_{\text {max }}=\varepsilon_{0}
\end{gathered}
$$

As curvas de variações das componentes de tensões e de deformaçōes são apresentadas na figura 5.2 para vários valores de n.

Tendo-se estabelecido as distribuições de tensão e de deformação por resolução numérica das equações 5.18 e 5.19 , pelo método de RUNGE-KUTTA, pode-se agora avaliar a integral-J pela introdução da equação 5.9 na equação da energia especifica de 
deformação:

$$
w=\frac{n}{n+1} \sigma_{1,} \varepsilon_{1 j}
$$

obtem-se:

$$
\mathrm{W}=\alpha \varepsilon_{0} \sigma_{0} \cdot \frac{\mathrm{n}}{\mathrm{n}+1}\left(\frac{\bar{\sigma}}{\sigma_{0}}\right)^{\mathrm{n}+1}
$$

Combinando as equações $5.10,5,16$ e 5.22 , obtém-se o seguinte resultado:

$$
J=\alpha \varepsilon_{0} \sigma_{0} K^{n+1} I_{n}
$$

onde:

$$
\begin{aligned}
& I_{n}=\int_{\pi}^{\pi}\left\{\frac{n}{n+1}\left(\frac{\tilde{\sigma}}{\sigma_{0}}\right)^{n+1} \cos \theta-\left[\frac{\tilde{\sigma}_{r r}}{\sigma_{0}}\left(\tilde{u}_{0}-\tilde{u}_{r}^{\prime}\right)+\right.\right. \\
& \left.+\frac{\tilde{\sigma}_{r \theta}}{\sigma_{0}}\left(\tilde{u}_{r}+\tilde{u}_{0}\right)\right] \operatorname{sen} \theta+ \\
& \left.-\frac{1}{n+1}\left[\frac{\tilde{\sigma}_{r r}}{\sigma_{0}} \tilde{u}_{r}+\frac{\tilde{\sigma}_{r \theta}}{\sigma_{0}} \tilde{u}_{0}\right] \cos \theta\right\} d \theta
\end{aligned}
$$

As quantidades $\tilde{u}_{r}$ e $\tilde{u}_{\theta}$ são obtidas de:

$$
\begin{gathered}
\tilde{u}_{r}=(n+1)\left(\frac{\tilde{\sigma}}{\sigma_{0}}\right)^{n-1}\left[\tilde{\psi}^{\prime}+s(3-s)^{\prime} / 2\right] \\
\tilde{u}_{0}^{\prime}=\frac{-1}{2}\left(\frac{\tilde{\sigma}}{\sigma_{0}}\right)^{n-1}\left[\tilde{\psi}^{\prime},-s(2 s-3) \tilde{\psi}\right]-\tilde{u}_{r}
\end{gathered}
$$

Usando a equação 5.25 para substituir $K$ na equação 5.12 , obtém-se, finalmente: 


$$
\begin{gathered}
\sigma_{\alpha \beta}=\left(\frac{J}{\alpha \varepsilon_{0} \sigma_{0} I_{n} r}\right)^{\frac{1}{n+1}} \tilde{\sigma}_{\alpha \beta}(\theta) \\
\sigma_{\alpha 3}=0 \\
\varepsilon_{\alpha \beta}=\alpha \varepsilon_{0}\left(\frac{J}{\alpha \varepsilon_{0} \sigma_{0} I_{n} r}\right)^{\frac{n}{n+1}} \tilde{\varepsilon}_{\alpha \beta}(\theta) \\
\varepsilon_{\alpha 3}=0 \\
u_{\alpha}=\alpha \varepsilon_{0}\left(\frac{J}{\alpha \varepsilon_{0} \sigma_{0} I_{n}}\right)^{\frac{n}{n+1}} r^{\frac{1}{n+1}} \tilde{u}_{\alpha}(\theta)
\end{gathered}
$$

Uma boa aproximação seria uma interpolação entre valores de $\tilde{\sigma}, \tilde{\sigma}_{\alpha}, \tilde{\varepsilon}_{\alpha \beta}$ eũ $\tilde{\alpha}^{\prime}$ em função do expoente de encruamento da fórmula de RAMBERG-OSGOOD, nas curvas $5.2 \mathrm{a}$ e $5.2 \mathrm{~b}$. 


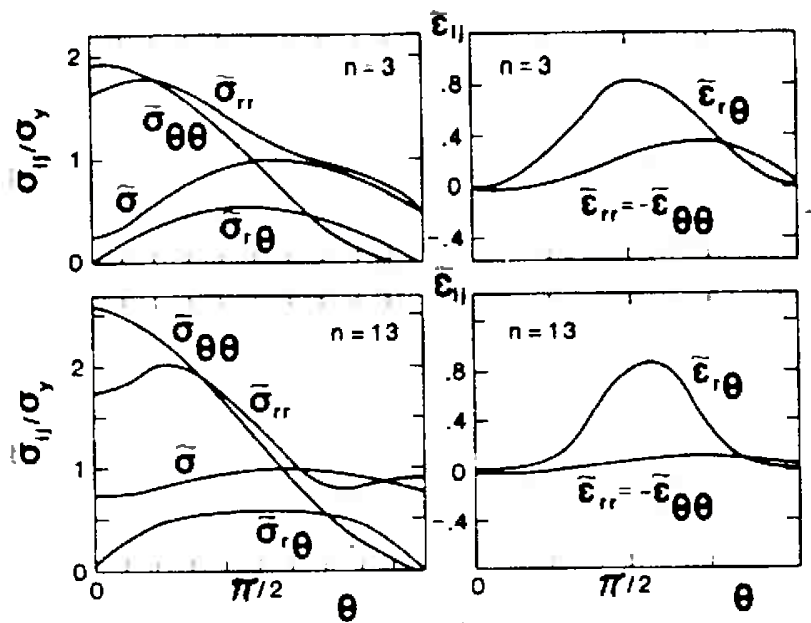

(a)

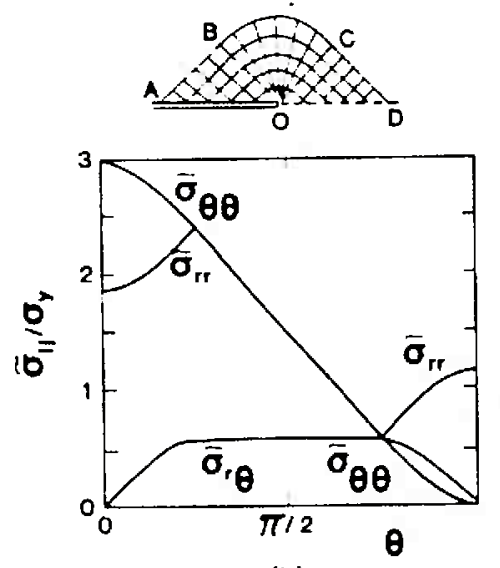

(b)

Figura 5.2a - Estruturas do modo I de trinca na deformação plana, diagramas das soluçōes da equação 5.18 , substituídas em 5.16 e 5.17 e, finalmente, em 5.12 , para vários valores do expoente de RAMBERG-OSGOOD e KANINEN ${ }^{24}$.

a) material encruado

b) material perfeitamente plástico 

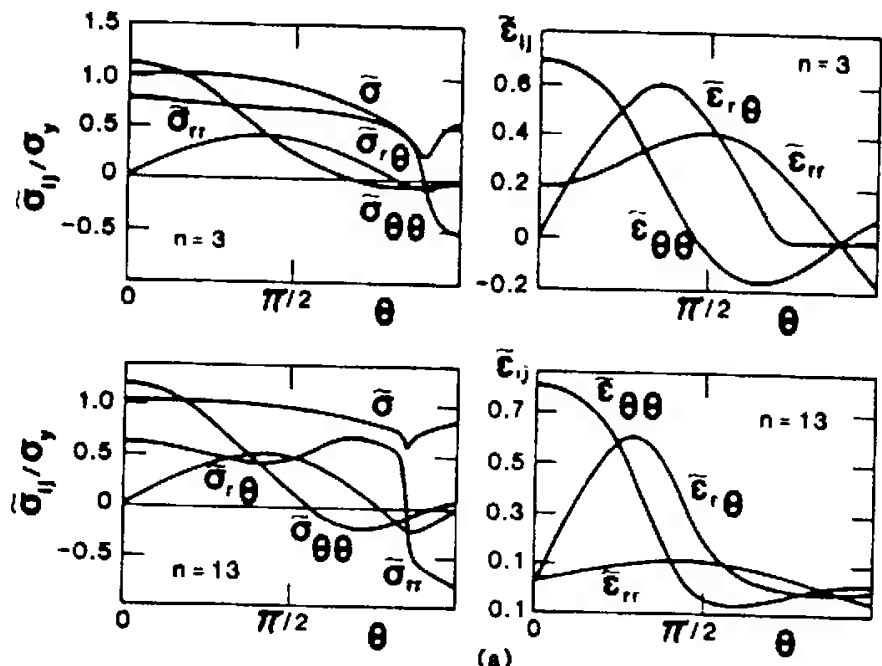

(a)
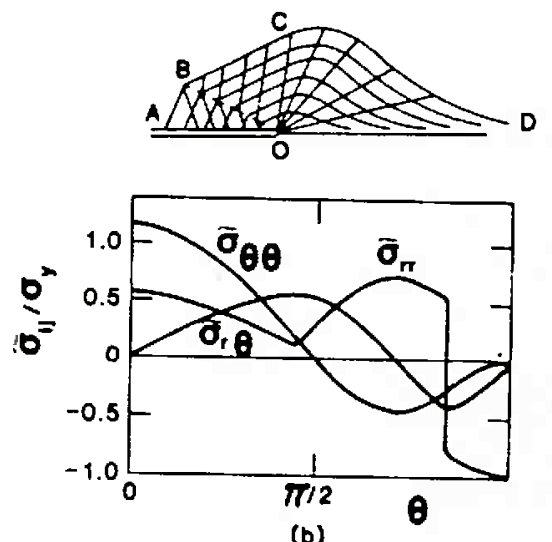

(b)

Figura 5.2b - Estruturas do modo $I$ de trinca na tensão plana, diagramas das soluções da equação 5.19 , substituídas, também, em 5.16 e 5.13. E, finalmente, em 5.12, para vários valores do expoente de RAMBERG, OSGOOD e KANINEN $^{24}$.
a) material encruado
b) material perfeitamente plástico 


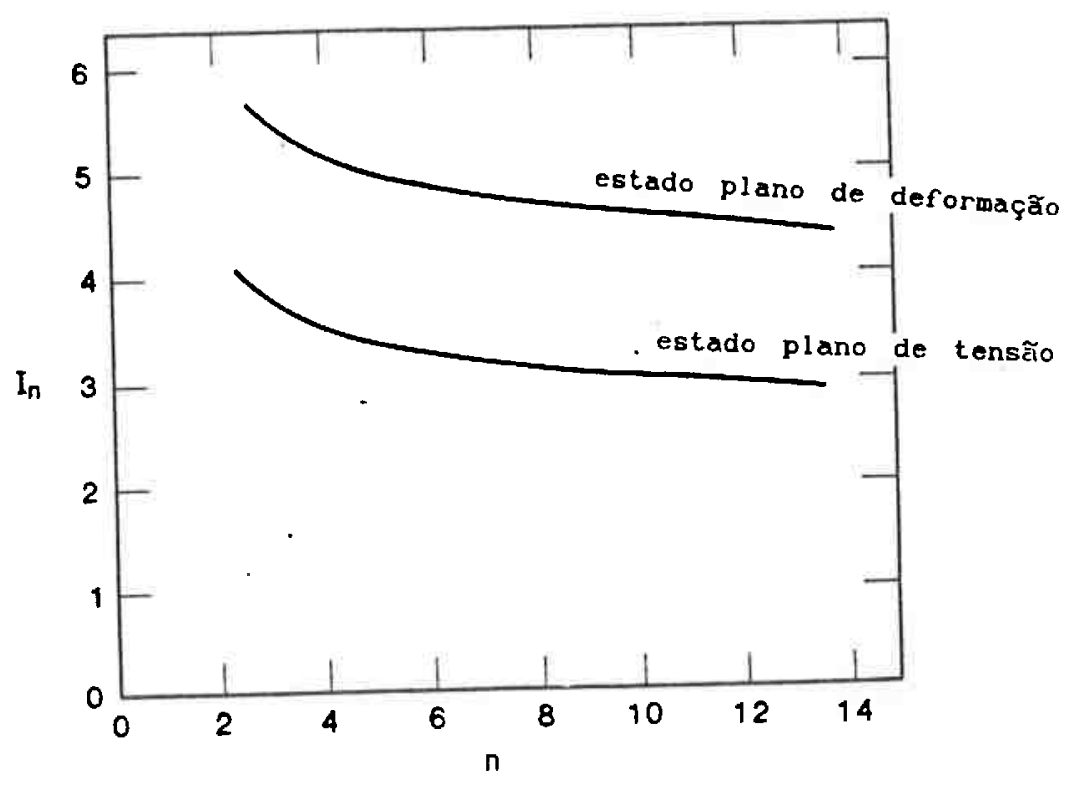

Figura 5.3 - Variação de $I_{n}$, com $n$ para tensão plana e deformação plana, segundo KANINEN ${ }^{24}$. 
A dificuldade em se calcular $I_{n}$ pela equação 5.26 pode ser removida pelo método de integração numérica de funções periódicas de FILON, conforme demonstrado em BLUM $^{25}$ " ou então por interpolação numérica na figura 5.3 .

5.3. Conformabilidade Plástica dos Metais pela Mecánica da Fratura NaัLinear

Considerando o caso da compressão quasi-estática de um corpo de prova cilíndrico em uma prensa hidráulica, a hipótese a ser adotada neste trabalho, é que na tegião frontal da trinca no equador o campo de tensão é o máximo possivel e o problema passa a ser do tipo estado plano de deformação. Nessa condição, serão adotados os parâmetros a serem obtidos das curvas segundo esse tipo de problema, com excessão do valor de $J$, que nește caso foi formulado através da relação 5.25 , e é portanto independente das condições impostas na solução analitica.

A integral-J de RICE será substituida pela integral invariante generalizada $\hat{J}$, expressa pela equação:

$$
\begin{aligned}
& \hat{J}_{k}=\int_{\Gamma_{\text {ftña } r}} \rho(K+e) n_{k} d \Gamma-\iint_{S+S_{S}} T_{1} \frac{\partial u_{i}}{\partial x_{l}} d s+ \\
& \iiint\left\{\sigma_{1 j} \frac{\partial \varepsilon_{1 j}}{\partial \mathrm{X}_{\mathrm{k}}}+\left(\rho \ddot{\mathrm{u}}_{\mathrm{i}}-\mathrm{F}_{1}\right) \frac{\partial \mathrm{u}_{1}}{\partial \mathrm{X}_{\mathrm{K}}}\right\} d V
\end{aligned}
$$

- critério de fratura para uma regiào $D$, figura 5.1, onde existe o dominio da integral-J é dado por:

$$
\mathrm{J}(\sigma, \mathrm{a})=\mathrm{J}_{\mathrm{c}}
$$


o crescimento da trinca, no interior dessa região $D$, é controlado pelo valor crítico da integral-J que é $J_{c}$, e é uma propriedade do material válida para solicitações externas aplicadas numa região bem afastada da ponta da trinca, onde "a" é tamanho da trinca.

A equação 5.28 mostra que as intensidades dọs campos de tensão e de deformação na ponta da trinca são dependentes do parâmetro_integral-J. . .

A equação do deslocamento relativo $u_{\alpha}$ representada na equação $5.28 \mathrm{c}$, quando expressa na forma planar, figura 5.4 , é do tipo:

$$
\left\{\begin{array}{l}
u_{1} \\
u_{2}
\end{array}\right\}=\alpha \varepsilon_{0}\left(\frac{J}{\alpha \varepsilon_{0} \sigma_{0} I_{n}}\right)^{\frac{n}{n+1}} \cdot r^{\frac{1}{n+1}}\left\{\begin{array}{ll}
\tilde{u}_{1}(\pi) \\
\tilde{u}_{2}(\pi)
\end{array}\right\}
$$

A definição do deslocamento relativo de abertura da trinca coD é dado por:

$$
\delta=2 u_{2}(r, \pi)
$$

TRACY, usando a ilustração da figura 5.4, definiu o deslocamento relativo da abertura da trinca,para uma interseção de duas linhas simétricas inclinadas de $\pi / 4$, ambas partindo da ponta da trinca, como sendo:

$$
r-u_{1}(\pi)=\delta_{t / 2}=u_{2}(\pi)
$$




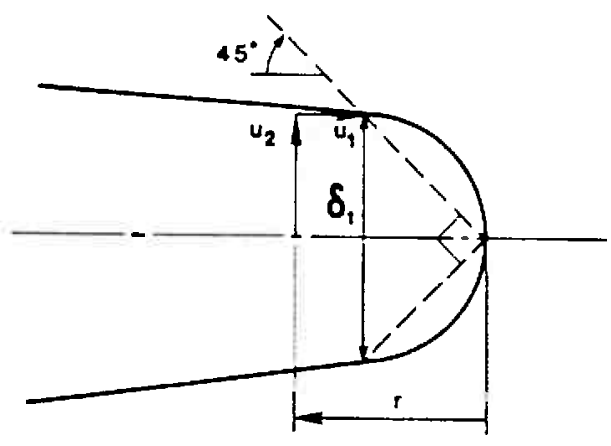

a.

I

Figura 5.4 - Definição do deslocamento de abertura da trinca COD, KANINEN $^{24}$. 
Das equações 5.30 e 5.31 , obtém-se:

$$
r=\left(\alpha \varepsilon_{0}\right)^{1 / n}\left[\tilde{u}_{1}(\pi)+\tilde{u}_{2}(\pi)\right]^{\frac{n+1}{n}} \frac{J}{\sigma_{0} I_{n}}
$$

que substituída na equação 5.30 novamente, fornece a equação:

$$
\delta_{t}=d_{n} J / \sigma_{0}
$$

onde:

$$
\mathrm{d}_{\mathrm{n}}=2\left(\alpha \varepsilon_{0}\right)^{1 / n}\left[\tilde{\mathrm{u}}_{1}(\pi)+\tilde{\mathrm{u}}_{2}(\pi)\right]^{1 / n} \tilde{\mathrm{u}}_{2}(\pi) / I_{\mathrm{n}} \quad 5.34
$$

SHIH $^{28}$ determinou a dependência de $d_{n}$ em função de $n$ e $\sigma_{0} / E$ para os casos planos de'deformação e de tensão, cujos resultados são mostrados na figura 5.5. Novamente, pode-se obter valores por interpolação gráfica para outros casos do expoente $n$ de RAMBERG-OSGOOD.

A equação 5.33 , segundo $\operatorname{KANINEN}^{24}$, estabelece uma equivalência entre os valores de $J$ e $\delta_{t}$ de tal modo que qualquer critério de fratura, baseado num valor critico $\delta_{t}$, é também equivalente a um outro baseado no valor critico J e vice-versa. 


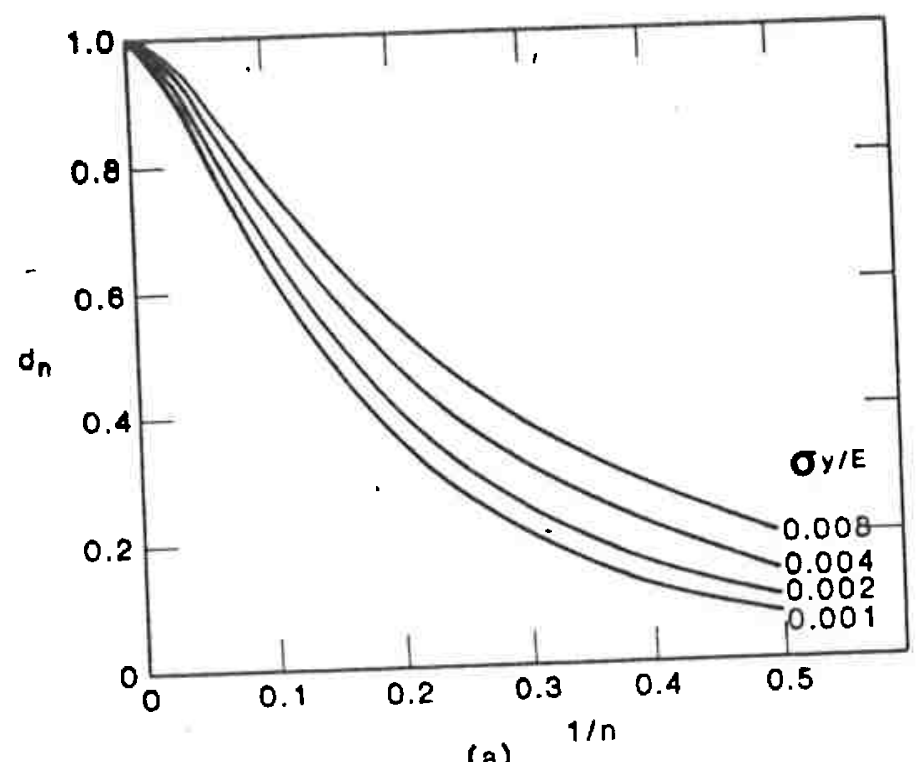

(a)

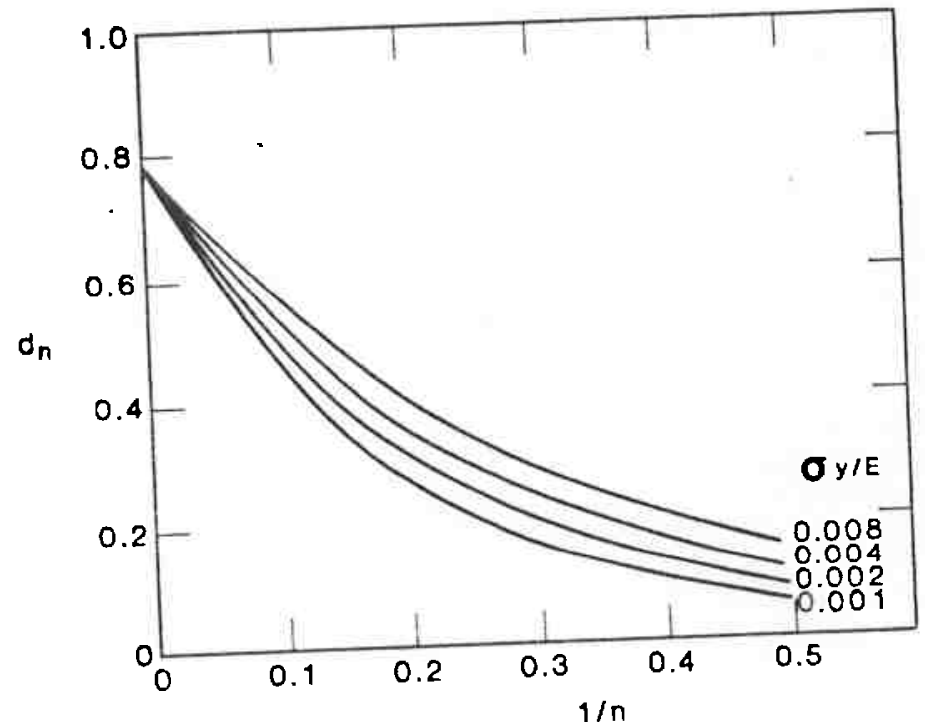

(b)

Figura 5.5 - Dependência de $d_{n}$ função de $n$ e $\sigma_{0} / E$ para os estados planos de (a) tensão e (b) deformação. 
Uma generalização do procedimento anterior seria estabelecer-se as relações para o caso das integrais invariantes do tipo $\hat{J}$, propostas por $\mathrm{AOKI}^{26}$, formando a expressão:

$$
\hat{\delta}=d_{n} \hat{J} / \sigma_{0}
$$

Uma expansão da definição da integral-J seria interpretá-la não como uma taxa de liberação de energia, mas sim como uma medida da intensidade dos campos HRR formados, criando-se assim uma base para análise pela mecânica da fratura.

A equação 4.49 aqui reproduzida:

$$
\Phi=v_{x} \hat{J}_{k}+w_{k}+\hat{L}_{x}+a \hat{M}+I
$$

pode ser reduzida à forma:

$$
\Phi=v \hat{J}
$$

quando se desprezam os efeitos da rotacionalidade, de expansão auto-similar, de inércia e térmico, dando como resultado os seguintes valores:

$$
\hat{\mathrm{L}}_{k}=\hat{\mathrm{M}}=\hat{\mathrm{I}}=0
$$

A expressão dada por 5.36 , quando substituída para o termo $\Phi$ da equação 3.123 , restabelece na equação $3.122,0$ enunciado de HILL, porém na seguinte forma:

$$
\int_{v b l u m e} \sigma_{i j} \frac{\partial w_{j}}{\partial x_{1}} d v=\int_{S^{S}} \sigma_{j} w_{j} d s-P \int_{S} n_{j} w_{j} d s+\gamma+v \hat{J} \quad 5.38
$$


o valor de $r$ é expresso por $3 . \dot{122}$

A equação 5.38 representa a forma unificada entre a teoria da plasticidade dos metais e a mecânica da fratura não-linear elasto-plástica.

Experimentalmente, a determinação de $\hat{\mathrm{J}}$ pode também ser obtida através da expressão de $\Phi^{*}$, dada pela equação 4.54 , onde:

$$
\Phi *=\lim _{\Delta \lambda \rightarrow 0} \frac{\Delta E}{\Delta \lambda}=\frac{d E}{d \lambda}
$$

sendo que:

$\Delta E$ é a taxa de energia total transferida por unidade de espessura e $\lambda$ é a medida de comprimento de arço do longo da frente da trinca, a partir de um ponto arbitrário. 


\section{REFERENCIAS BIBLIOGRAFICAS - Capitulo 5}

1. DIETER, G. Chapter 1 - overview of workability. In: DIETER, G. (ed.) Workability Testing Techniques. Metals Park, American Society for Metals, 1984.'p.1-20

2. OSKADA, K. and MORI, K. Predicition of ductile fracture in cold forming. Annals of the CIRP; 27(1):135-139, 1978.

3. ZAVAgliA, C.A.C. Conformabilidade Plástica de Fios Capilares de Ouro na Trefilação,tese de Doutoramento em Engenharia Mecânica, Universidade Estadual de Campinas, 1988. pp.103$-106$.

4.VINH,T.Sur les critèresde rupture ductile - applications à quelques problems de formage. Sciences et Techniques de I'Armement, 56(2):387-420, 1982.

5. MCCLINTOCK, F.A. A criterion for ductile fracture by growth of holes. Translactions of the ASME, Journal of Apllied Mechanics. 35(6):363-371, 1968.

6. THOMASON, P.F. A theory for ductile fracture by internal necking of cavities. Journal of Institute of Metals, 96:360$-365,1968$.

7. RICE, J.R. On the ductile enlargement of voids. Journal of Mechanics and Physics of Solids, 17(3):201-217,. 1969.

8. ARGON, A.S.; IM, J. and SAFOGLU, R. Cavity formation from inclusions in ductile fracture.Metallurgical Transactions $A$, 6:825-837, 1975 .

9. HADDAD, Y.M. and SOWERBY, R. A micro probabilistic approach to the ductile deformation and fractureof metals. Advances in Research on the strenght and Fracture of Materials, vol. 2A, London, Pergamon Press, 1977. pp.457-465.

10.RICE, J. R. Mathematical analysis in the mechanics fracture. In: LIEBOWITZ, H. (ed.) Fracture: an advanced treatise. New York, Academic Press, 1968. pp.51-58.

11. GURSON, A.I. Porous rigid-plastic materials containing rigid inclusions - yield function, plastic potential and void nucleation. In: Advances in Research on the strength and Fracture of Materials. London, Pergamon Press,. 1977. vol.2A, pp. 357-364. 
12. SEAMAN, L; CURRAN, D.R. and SHOCKEY, D.A.Computational model for ductileand brittle fracture. Journal of Applied Physics, 41(11):4814-4826, 1976.

13.GHOSH, A.K.; HECKER, S.S. and KEELER, S.P. Sheet metal forming and testing. In:DIETER, G.E. Op. cit., referência 1. pp. 135-193.

14. ALTAN, T.; OH, SOǑ-Ik and GEGEL, H. L. Metal Forming fundamentals and applications. Metals Park, American Society for Metals, 1983. pp.45-82.

15. COCKCROFT, M.M. and LATHAN, D.J. Ductility and wórkability of metals. Journal of Institute of Metals, 96:33, 1968.

16. GILLEMOT, L.F. Criterion of crack initiation and spreading. Engineering Fracture Mechanics, 요239-253, 1976.

17. OH, S.I.; CHEN, C.C. and KOBAYASHI, S. Ductile fracture in axisymetric extrusion and drawing, part 2: workability in extrusion and drawing. Transactions of the ASME, Journal of Engineering for Industry, 101:36-44, 1984 .

18. SEKIGUSHI, H.; OSAKADA, K. and HAYASHI, H. A criterion for ductile fracture strain in tensile test carried out under high hidrostaticpressures. Journal of Institute of Metals, 101:167, 1973 .

19. HOLLOMON, J.H. Teńsile deformation. Transactions of AIME, $162: 268-290,1945$.

20. HUTCHINSON, J.W. Singular behaviour at the end of a tensile crack in a hardening material. Journal of the Mechnical and Physics of Solids. 16:13-31, 1968.

21. RICE, J.R. and ROSENGREN, G.F. Plane strain deformation near a crack tip in a power-law hardening material. Journal of the Mechanics and Physics of Solids. 15:1-12, 1968.

22. RAMBERG, $W$. and OSGOOD, W. Description OI stress-strain curves by three parameters. NACA TN 902, Jul.1943.

23. ZyCZKowsKI, M. Combined Loadings in the Theory of Plasticity. Warzawa, PWN-Polish Scientific Publishers, 1981, pp.172-205. 24. KANINEN, M.F. and POPELAR, C.H. Advanced Fracture Mechanics. Oxford/New York, University Press, 1985. Chapter 5, ElasticPlastic Fracture Mechanics, pp.138-191, 281-391.

25. BLUM, E.K. Numerical Analysis and Computation: theory and 
practice. Reading, MA, Addison-Wesley, 1972. pp.380-513. 26. AOKI, S.; KISHIMOTO, K. and SAKATA, M. Energy flux into process region in elastic-plastic fracture problems. Engineering Fracture Mechanics, 19(5):827-836, 1984.

27. TRACY, D.M. Finite element solutions for crack - tip behaviour in small scale yielding. Journal of Engineering Materials and Technology, 98:146-151, 1976.

28.SHIH, C.F. Relationship between the $\mathrm{J}$ - integral and the crack opening displacement for stationary andextending cracks. Journal of the Mechanics and Physics of Solids, 29:305-326. 


\section{DESENVOLVIMENTO EXPERIMENTAL}

\section{I Consideraçర̃es Iniciais}

E utilizado neste trabalho o ensaio de compressão para corpos metálicos cilíndricos, com dimensões padronizadas $\mathrm{H}_{0} \mathrm{e} \mathrm{D}_{0}$, respectivamente altura e diâmetros iniciais. Para assegurar a ausência de flambagem, de acordo com a norma $\operatorname{ASTM}^{1}$ a seguinte limitação foi obedecida para os valores de $H_{0}$ e $D_{0}: H_{0} / D_{0} \leq 2,0$, com valores típicos definidos no intervalo $0,75 \leq H_{0} / D_{0} \leq 1,75$, de acordo com $\mathrm{LEE}^{2}$ e colaboradores. O ensaio de compressão de corpos metálicos cilíndricos tém sido utilizado por vários pesquisadores: KUDO e AOI $^{3}$, THOMASON ${ }^{4}$ KOBAYASHI ${ }^{5}$, KHUN ${ }^{6}$ e colaboradores para 0 estudo da fratura sob as mais complexas combinaçōes de tensões.

Durante o processo de compressão, a superficie lateral de um cilindro reto sofre um abaulamento como é mostrado na figura 6.1 , o que possibilita portanto o surgimento de trincas do tipo quasi-axiais próximas ao seu equador. Essas trincas superficiais também ocorrem nos processos de conformação plástica por dobramento e por laminação. Contudo trincas internas do tipo bifurcante ocorrem principalmente nos processos de extrusão e de trefilação. Essas trincas, que ocorrem por mecanismos de fratura dúctil, foram objeto de "intensivos estudos segundo JENNER e DODD? 


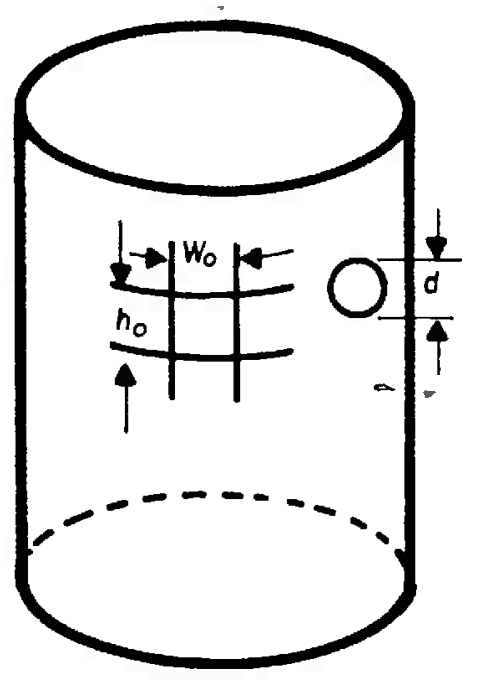

(a)

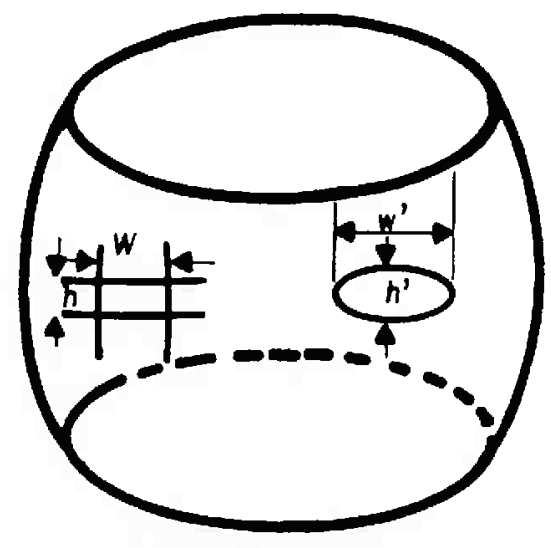

(b)

Figura 6.1 - Diagrama esquemático do ensaio de compressão deformação axial $\varepsilon_{z z}^{\prime}=$ In $\left(h / h_{0}\right)$ deformação circunferencial $\varepsilon_{\theta \Theta}=\ln \left(\mathrm{w} / \mathrm{w}_{0}\right)$

a) situação inicial: $H_{0}, D_{0}, h_{0}, w_{0} e h^{\prime}$

b) situação deformada: $H, D, h, w, w^{\prime}$ e $h^{\prime}$ 


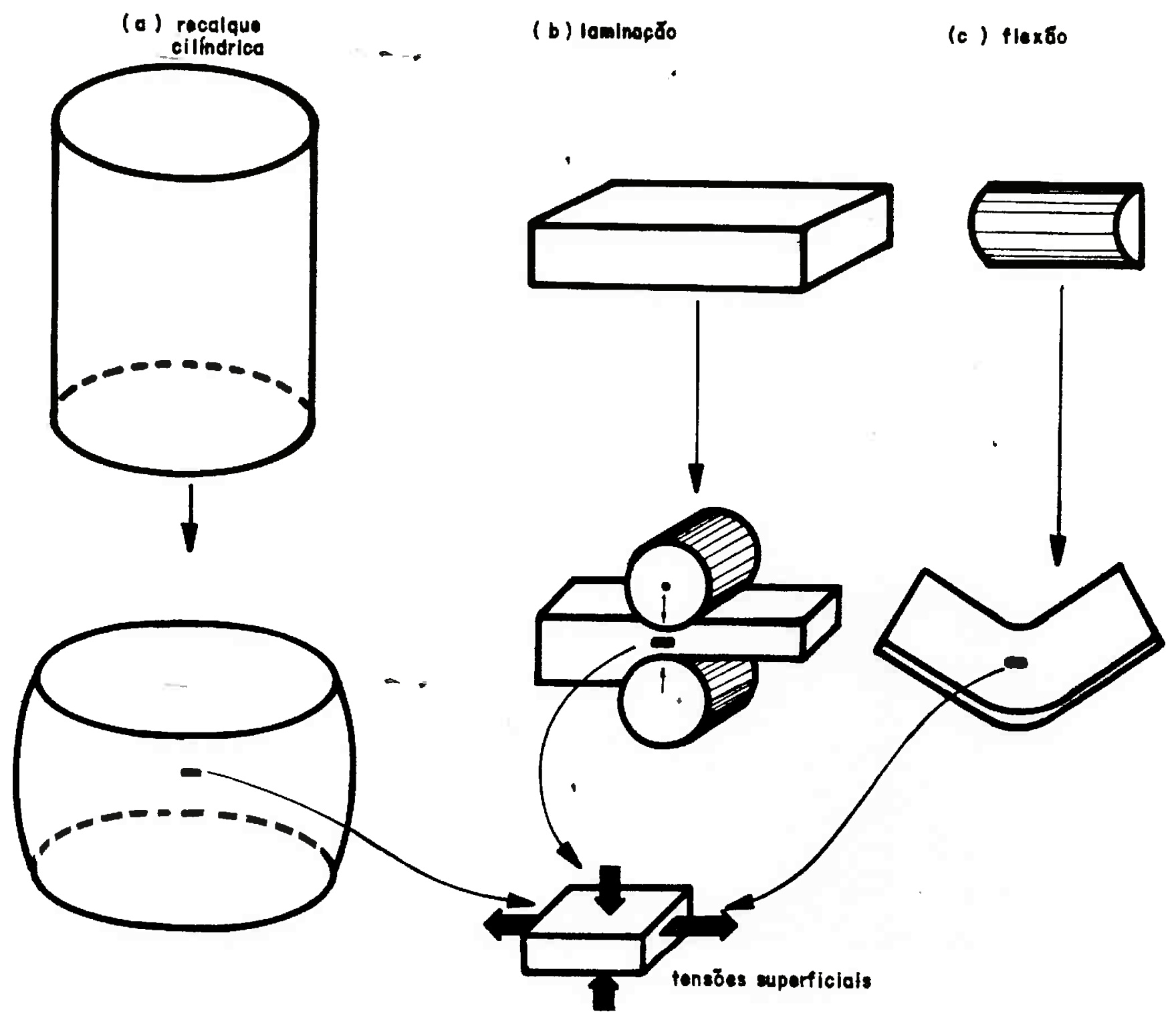

Figura 6.2 - Ilustração dos estados superficiais de deformaçōes para os ensaios: a) compressão, b) laminação e c) dobramento

No caso do ensaio de compressão, o abaulamento resulta no desenvolvimento de tensão de tração na direção tangente à curva 
circunferencial e também provoca uma diminuição na magnitude da tensão axial compressiva para um valor abaixo da tensão compressiva média no material. Caso haja a ocorrência de um severo abaulamento, até mesmo a tensão axial passa a ser do tipo de tração.

Através de variações na razão entre a altura e diâmetro do cilindro e também nas condições de atrito nas superficies em contatos entre esse cilindro e a matriz, é possivel controlar a severidade-da curvatüra-de abaulamento do cilindro. A variedade de estados de tensão e de deformação que pode ser gerada na região equatorial dos cilindros sob prbcesso de compressão, fornece um modo conveniente de ensaios para os estudos de fratura dúctil na conformação plástica de metais e consequentemente para o estudo da conformabilidade.

Para avaliar a possibilidade de ocorrência de fratura em material sob condições especificas de um processo de conformação, é necessário combinar os ensaios de conformabilidade com um critério de fratura, como foi demonstrado no capitulo 5 para os critérios de fraturas baseados em integrais invariantes.

\subsection{Material para os Ensaios}

o material metálico utilizado nos experimentos para a simulação do forjamento a frio em matriz aberta através do ensaio de compressão, sob duas diferentes condições de atrito, foi uma liga de aluminio-cobre trefilada, cuja composição, mostrada na tabela 6.1, foi determinada através de um espectrofotômetro de fluorescência por raio-X de energia dispersiva do tipo analisador químico semi-quantitativo modelo EG\&G ORTEC, pertencente ao centro de Pesquisa e Desenvolvimento da Telebras, localizado em 
Campinas-SP. A essa liga foi dada a Genominação de UNS A92014, modificada pela presença de $\mathrm{Pb}$ em teor elevado.

Para garantir o aparecimento de trincas nas superficies dos corpos de provas e ao mesmo tempo devido ao desconhecimento dos tratamentos mecânicos e térmicos prévios, foi realizado o tratamento $T 6$, com o objetivo de obter-se uma propriedade de redução de área, num corpo de prova de tração, da ordem de $\mathrm{R}=15 \%$.

o tratamento T6 consistiu na solubilização da liga por 2 horas a uma temperatura de $500^{\circ} \mathrm{C}$, seguido de envelhecimento por precipitação por 4 horas a una temperatura de $182^{\circ} \mathrm{C}$, tratamento esse realizado no laboratório do Departamento de Engenharia Metalúrgica da EPUSP.

6.3 Determinação das Expressớes da Relação Tensão versus Deformaçăo

Após esse tratamento, os corpos de prova de tração foram ensaiados no laboratório de Ensaios Mecânicos do IPT, obtendo-se como resultados as expressões mostradas na tabela 6.2 , obtidas através de regressão não-linear dos dados experimentais pelo uso do programa BMDP-P3R, desenvolvido segundo o modelo proposto por JENNRICH ${ }^{12}$. 
Tabela 6.1 - Composição e microestrutura da liga UNS A92014-T6

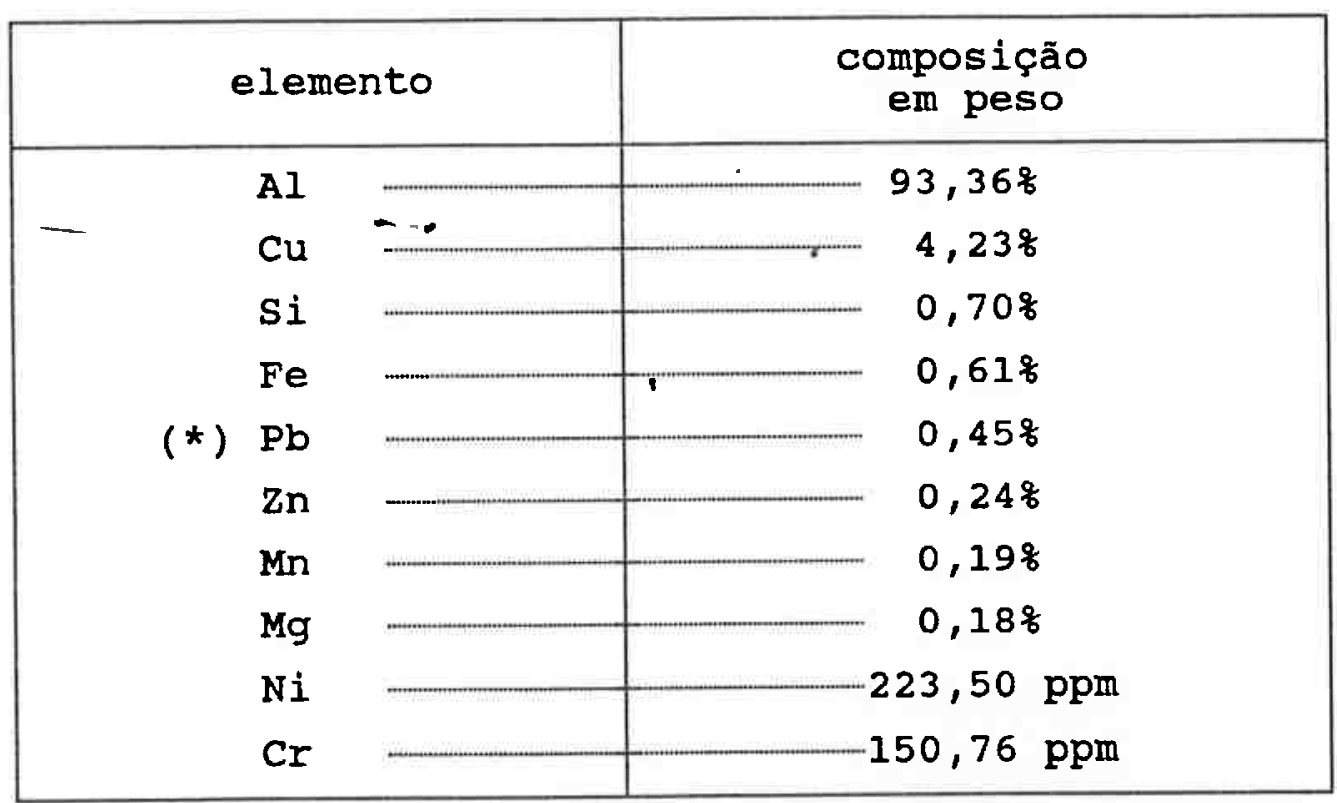

* traço de $\mathrm{Pb}$ não presente na liga comercial UNS A92014-T6

Microestrutura observada no microscópio:

tamanho de grão médio = ;

precipitados : partículas de compostos intermetálicos de Al e Cu e de particulas de $\mathrm{Pb}$; 
Tabela 6.2. - Expressões do ensaio de tração da liga UNS A92014-T6 (*)

\begin{tabular}{|c|c|c|}
\hline tipo de expressão & RAMBERG-OSGOOD ${ }^{13}$ & HOLLOMON ${ }^{14}$ \\
\hline $\begin{array}{l}\text { numero de } \\
\text { parámetros }\end{array}$ & 2 & 2 \\
\hline parâmetros & $\mathrm{n}, \alpha$ & $N, \mathrm{~K}$ \\
\hline expressão & $\frac{\varepsilon}{\varepsilon_{0}}=\frac{\sigma}{\sigma_{0}}+\alpha\left(\frac{\sigma}{\sigma_{0}}\right)^{n}$ & $\sigma=K \varepsilon^{N}$ \\
\hline \multirow[t]{4}{*}{ valores experimentais } & $\sigma_{0}=\sigma_{0,01 x}=282,70 \mathrm{MPa}$ & $\mathrm{K}=253,12 \mathrm{MPa}$ \\
\hline & $\varepsilon_{0}=38,33 \times 10^{-4}$ & $\mathrm{~N}=0,09$ \\
\hline & $\mathrm{n}=18$ & \multirow{2}{*}{$\sigma_{r \circ 8}=388,70 \mathrm{MPa}$} \\
\hline & $\alpha=0,0011$ & \\
\hline
\end{tabular}

* Observação: Os parâmetros foram obtidos por regressão não-linear através do programa BMDP - P3R 
6.4 Determinaçåo do Coeficiente de atrito e das cargas de

\section{Compressão}

As condições de atrito, para utilização no problema proposto, foram estabelecidas através da aplicação do ensaio do anel sugerido por MALE e COCKROFT ${ }^{8}$. As determinações dos coeficientes de atrito $\mu$ de COULOMB foram obtidas através da figura 6.3 , em MALE ${ }^{9}$, segundo a proporcionalidade entre as dimensões iniciais da forma: $D_{\text {oexterno }}: D_{\text {olnterno }}: H_{0} \equiv 48,10 \mathrm{~mm}: 20,00 \mathrm{~mm}: 16,00 \mathrm{~mm}$. os resultados dos coeficientes de atrito estão apresentados na tabela 6.3.

-o cálculo da carga de rẹcalque ou compressão de cilindros seguiu a formulação proposta por RICHARDSON ${ }^{10} e$ colaboradores, na forma:

$$
\mathrm{P}=\pi \mathrm{D}_{\mathrm{O}}^{2} \frac{\mathrm{H}_{\mathrm{O}}}{\mathrm{H}} \quad \mathrm{K} \varepsilon^{N} \dot{\varepsilon}^{\mathrm{M}}\left\{1+\frac{2 \mathrm{~m} \mathrm{D}_{\mathrm{O}}}{3 \sqrt{3} \mathrm{H}_{\mathrm{O}}}\left[\frac{\mathrm{H}_{\mathrm{O}}}{\mathrm{H}}\right]^{3 / 2}\right\}
$$

onde:

$\mathrm{P}$ : carga externa a ser avaliada em $\mathrm{kN}$

$D_{0}$ e D : diâmetros inicial e final do corpo de prova

$\mathrm{H}_{0}$ e $\mathrm{H}$ : alturas inicial e final nos ensaios

m: fator de atrito constante, obtido pela relação dada por 3.144

ć: é a taxa de deformação

$\mathrm{N}$ : é o expoente de encruamento de HoLLOMON

M: expoente de sensibilidade à, taxa de deformação e $M=0$ para ensaios quasi-estáticos

K: é o fator de resistência na expressão de HOLLOMON.

A expressão 6.1 foi utilizada para a determinação da capacidade de carga para seleção do equipamento de ensaio. Tabela 6.3 - Determinação do coeficiente de Atrito 
4. pelo ensaio de anel.

\begin{tabular}{|c|c|c|}
\hline $\begin{array}{l}\text { Condição de } \\
\text { lubrificação } \\
\text { nas interfaces } \\
\text { do anel }\end{array}$ & $\begin{array}{l}\text { óleo lubrificante } \\
\text { SAE } 20 W-40 \\
\text { Classificação API-SF }\end{array}$ & $\begin{array}{l}\text { ausência de } \\
\text { lubrificante } \\
\text { (a seco) }\end{array}$ \\
\hline $\begin{array}{l}\text { Variação do diâmetro } \\
\text { interno } \\
\left(\frac{\Delta D}{D_{0} \text { interno }}\right)_{\text {med10 }}\end{array}$ & $-2,25 \pm 0,518$ & $20,98 \pm 5,238$ \\
\hline 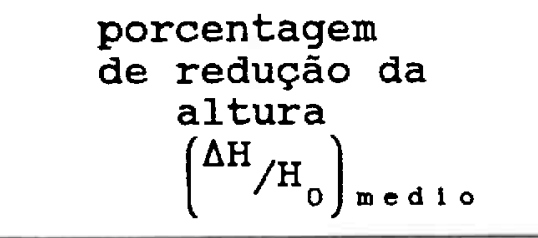 & $15,73 \pm 3,048$ & $31,88 \% \pm 5,058$ \\
\hline $\begin{array}{c}\text { valor do coeficiente } \\
\text { de atrito } \\
\mu\end{array}$ & $0,033 \pm 0,005$ & $0,319 \pm 0,050$ \\
\hline
\end{tabular}

Os valores de atrito para as condições de ensaios foram obtidos por interpolação gráfica na figura 6.3 , por meio do ensaio de anel MALE ${ }^{8,6}$, baseados nos ensaios de três anéis para cada tipo de condição de lubrificação na interface, em temperatura ambiente. oserros foramestimados de acordo com a metodologia apresentada em HOLMAN ${ }^{11}$.

As figuras 6.4 e 6.5 mostram as respectivas cargas avaliadas através da équação 6.1 . e as aplicadas experimentalmente nos ensaios. 
200

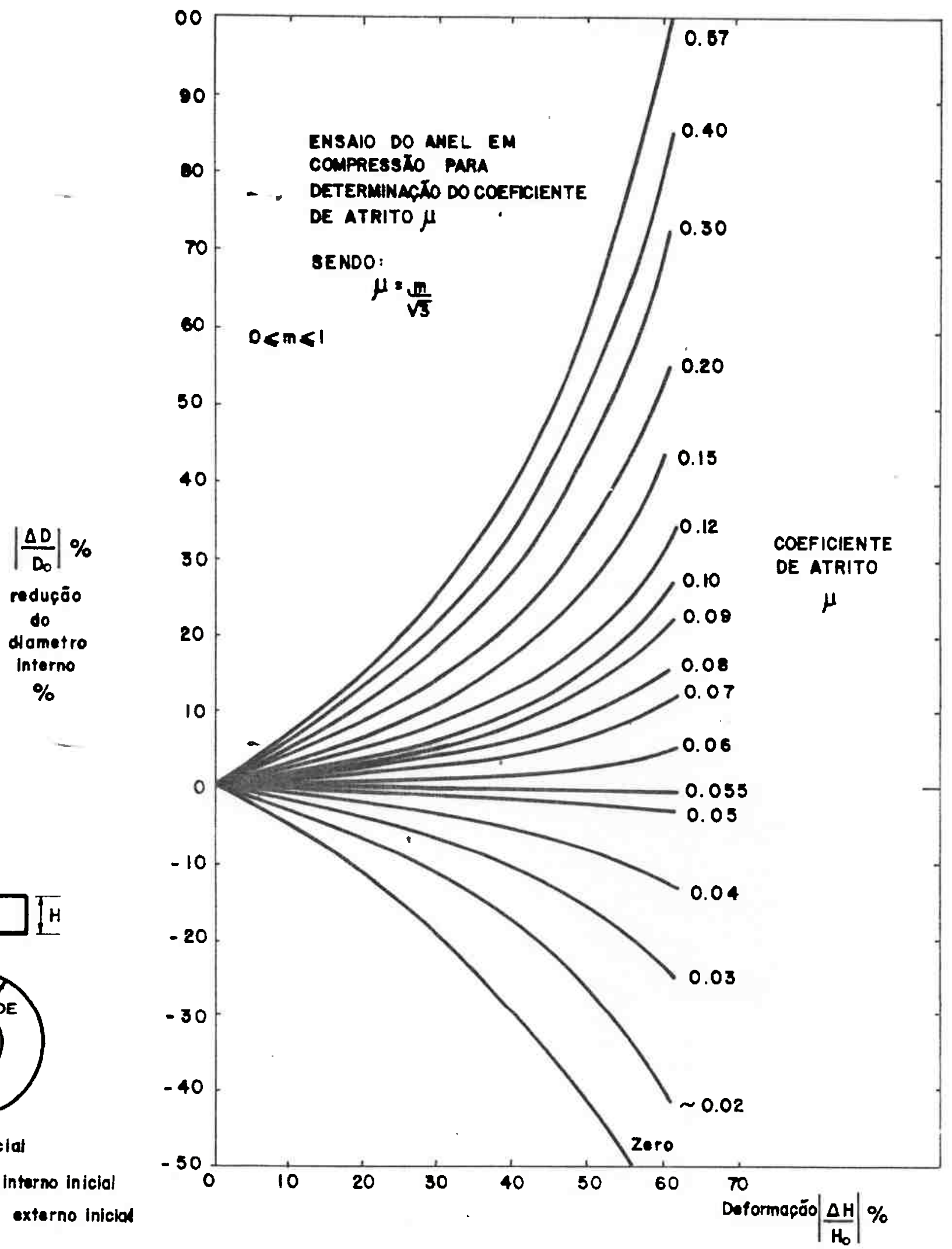

Figura 6.3 - Diagrama para determinação do coeficiente de atrito $\mu$, pelo ensaio de anel. $\mathrm{MALE}^{8,9}$. 


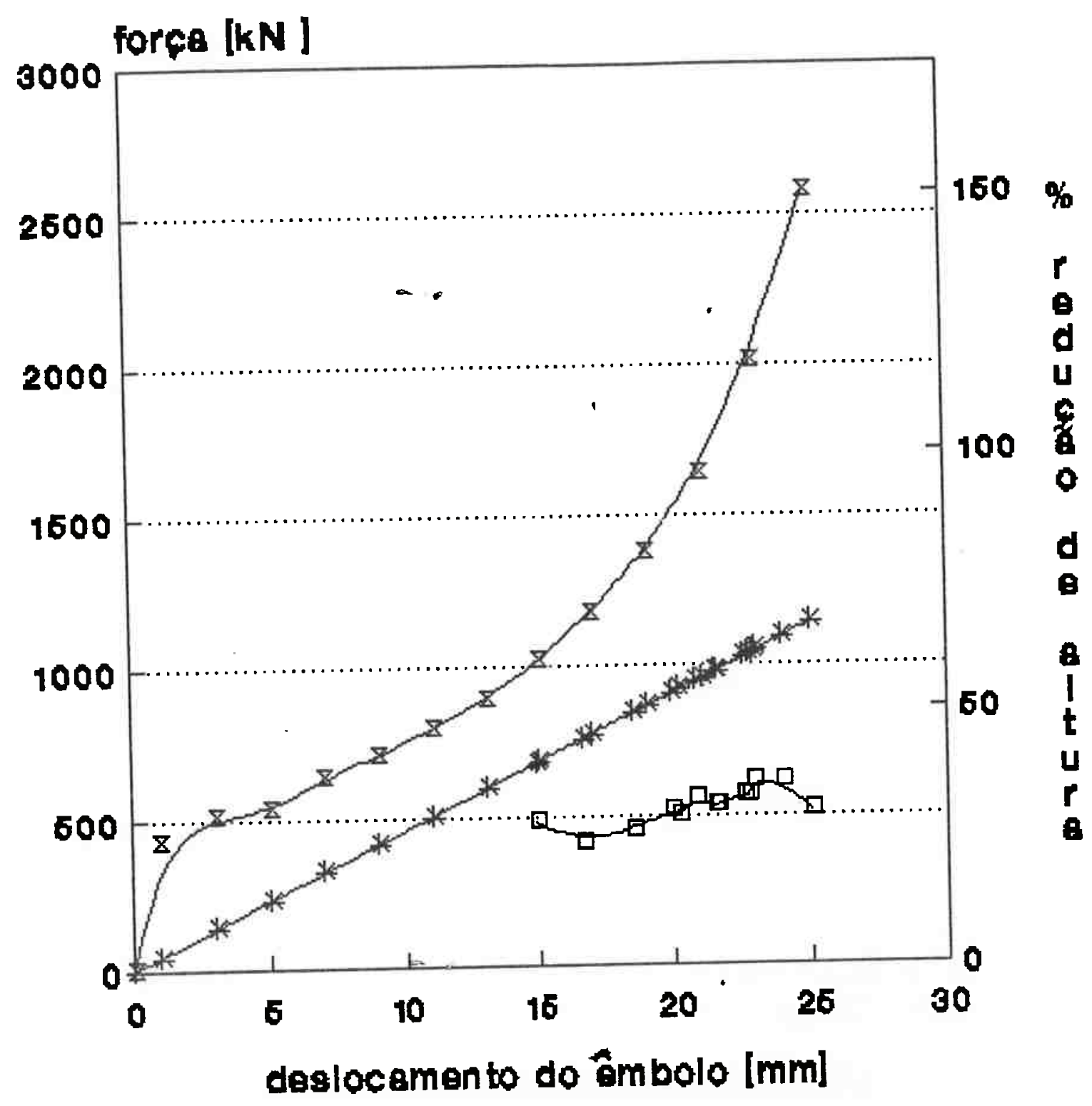

I- forpa estimada [kN] $\square$ forpa observada [KN]

* redupão alt $\%$

$$
\begin{aligned}
\text { Figura 6.4 - } & \text { Cargas para } \mu=0,319 \pm 0,050 \\
& \text { a seco, superfícies como } \\
& \text { torneadas por faceamento } \\
& \text { de desbaste. }
\end{aligned}
$$




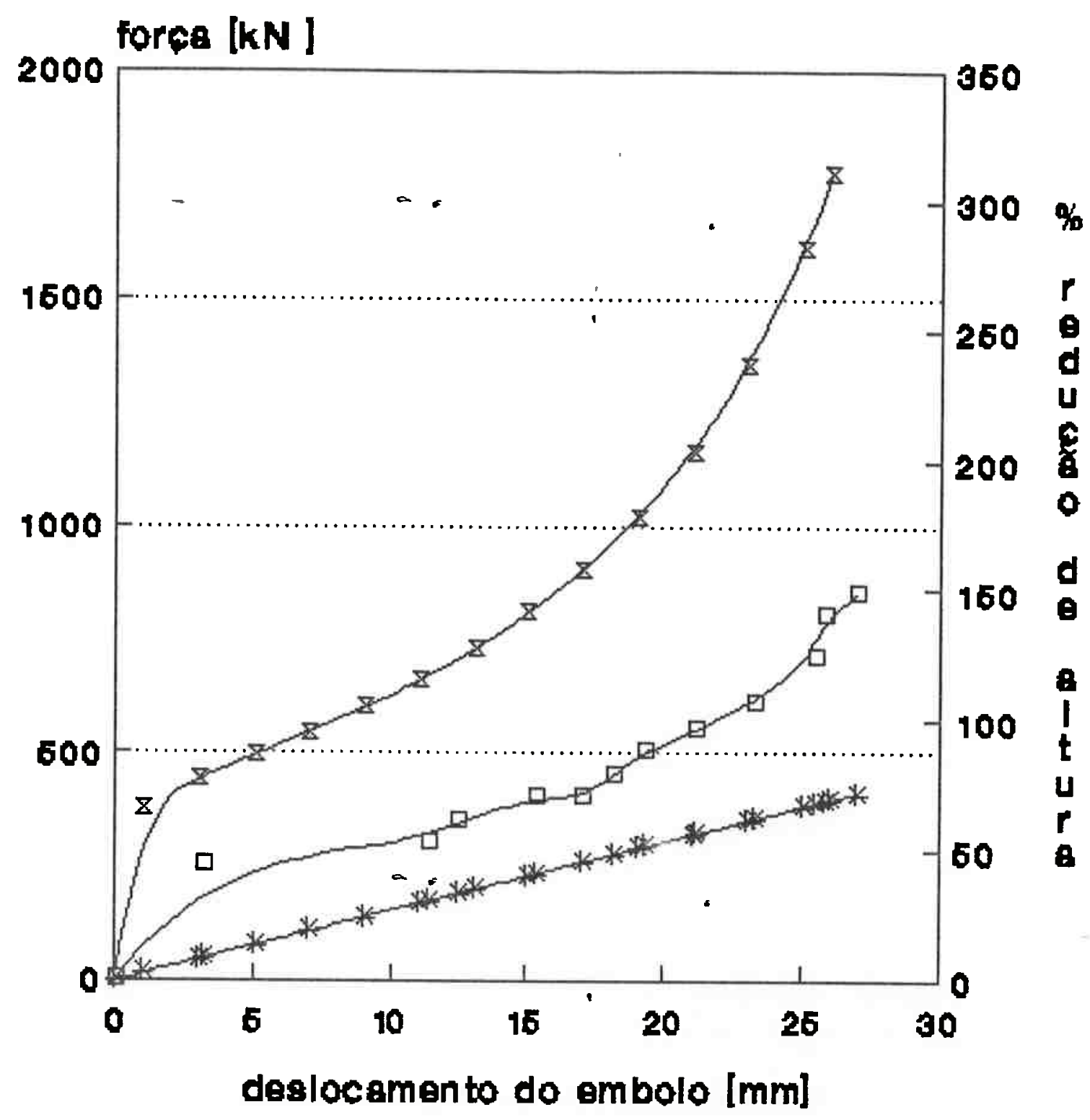

\section{I- forpa estimada [kN]- força observada [kN] * redução alt $\%$}

$$
\text { Figura } \begin{aligned}
6.5- & \text { Cargas para } \mu=0,033 \pm 0,005 \\
& \text { óleo lubrificante automotivo } \\
& \text { SAE } 20 W-40 \\
& \text { Classificação API-SF }
\end{aligned}
$$




\subsection{Ensaios de Conformabilidade}

os ensaios de conformabilidade estabelecem a ductilidade do material sob condiçōes padronizadas. E como na maioria dos processos de conformação plástica observa-se a ocorrência de deformaçōes compressivas então, o ensaio de compressão será sempre o mais apropriado a ser aplicado na prática.

Os ensaios de conformabilidade, como serão denominados, foram realizados segundo os procedimentos relevantes especificados pela norma $\operatorname{ASTM}^{15}$ E 813-87, referente a ensaios para a determinação experimental da tenacidade à fratura $\mathrm{J}_{\text {Ic }}$ •

o caso da compressão quasi-estática de corpos de provas cilindricos representa a simulação do forjamento em matriz plana de tarugos cilínarico com velocidade de avanço do êmbolo constante. o mesmo caso difere em muitos aspectos do ensaio para a determinação de $J_{1 c^{\prime}}$ maś àinda é de fundamental importância para a quantificação e elaboração dos diagramas de conformabilidade.

Uma máquina de ensaio de compressão com capacidade para $2000 \mathrm{kN}$, pertencente ao Laboratório de Ensaios Mecânicos do IPT, foi utilizada para a realização dos ensaios deste trabalho.

Um microscópio otico com equipamento fotomicrográfico da marca Jenavert, modelo mf-AKS $24 \times 36$ automatic-2, fabricado pela Carl zeiss, pertencente à Divisão de Mecânica e Eletricidade do IPT, foi utilizado para o registro e medição das fraturas que ocorreram nas superficies dos corpos de provas.

o procedimento experimental, de acordo com o proposto pela ASTM5 , consistiu nà compressão independente de no mínimo seis corpos de provas de dimensões padronizadas,como mostra a figura 6.4, sob uma especificada condição de atrito na interface material metálico-matriz. 
Cada corpo de prova foi levado, em uma primeira fase e na medida do possível, a uma condição de carregamento extremo, cujo objetivo foi o de provocar o surgimento de trincas superficiais possiveis te serem visiveis a olho nu.

Foram realizados os registros das condições de atrito, das reduções de alturas, das medições das grelhas gravadas nas superfícies para avaliação das deformações locais, dos registros das cargas externas e das medições das aberturas máximas das trincas, com referência básica no equador dos corpos de provas. 

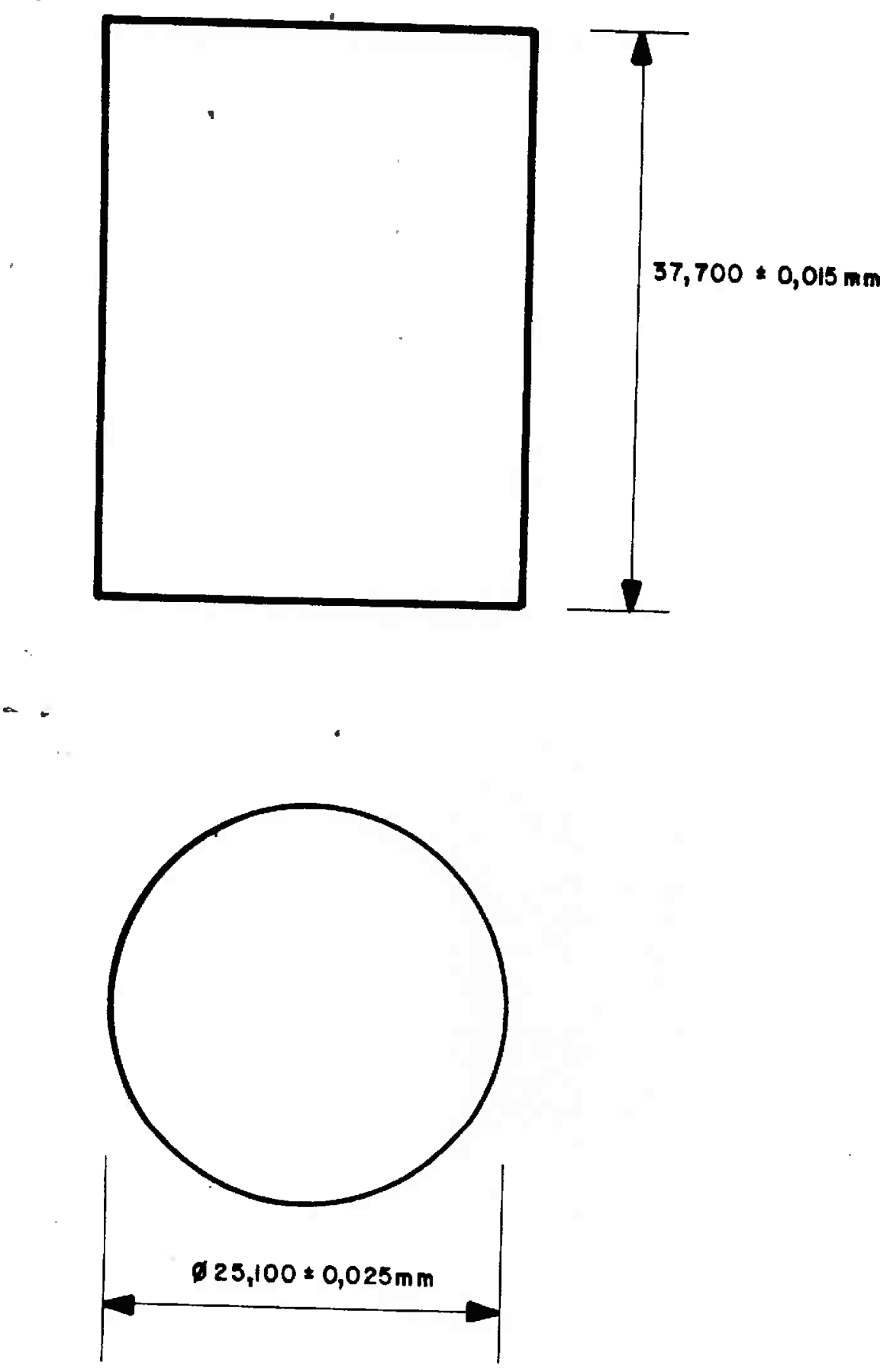

Figura 6.6 - Dimensões dos corpọs de provas, padronizadas para a realização do ensaio de conformabilidade. 
Em uma segunda fase, os ensaios consistiram em registrar os aumentos nas dimensões das trincas após respectivos aumentos nas cargas, possibilitando a o registro dos valores incrementais de abertura das novas e as das já existentes trincas.

Os resultados obtidos nos ensaios são apresentados nas figuras 6.7 e 6.8, para os casos iniciais de aparecimento ou não de trincas superficiais e tambem para os casos finais nas condições de ensaios especificadas. 


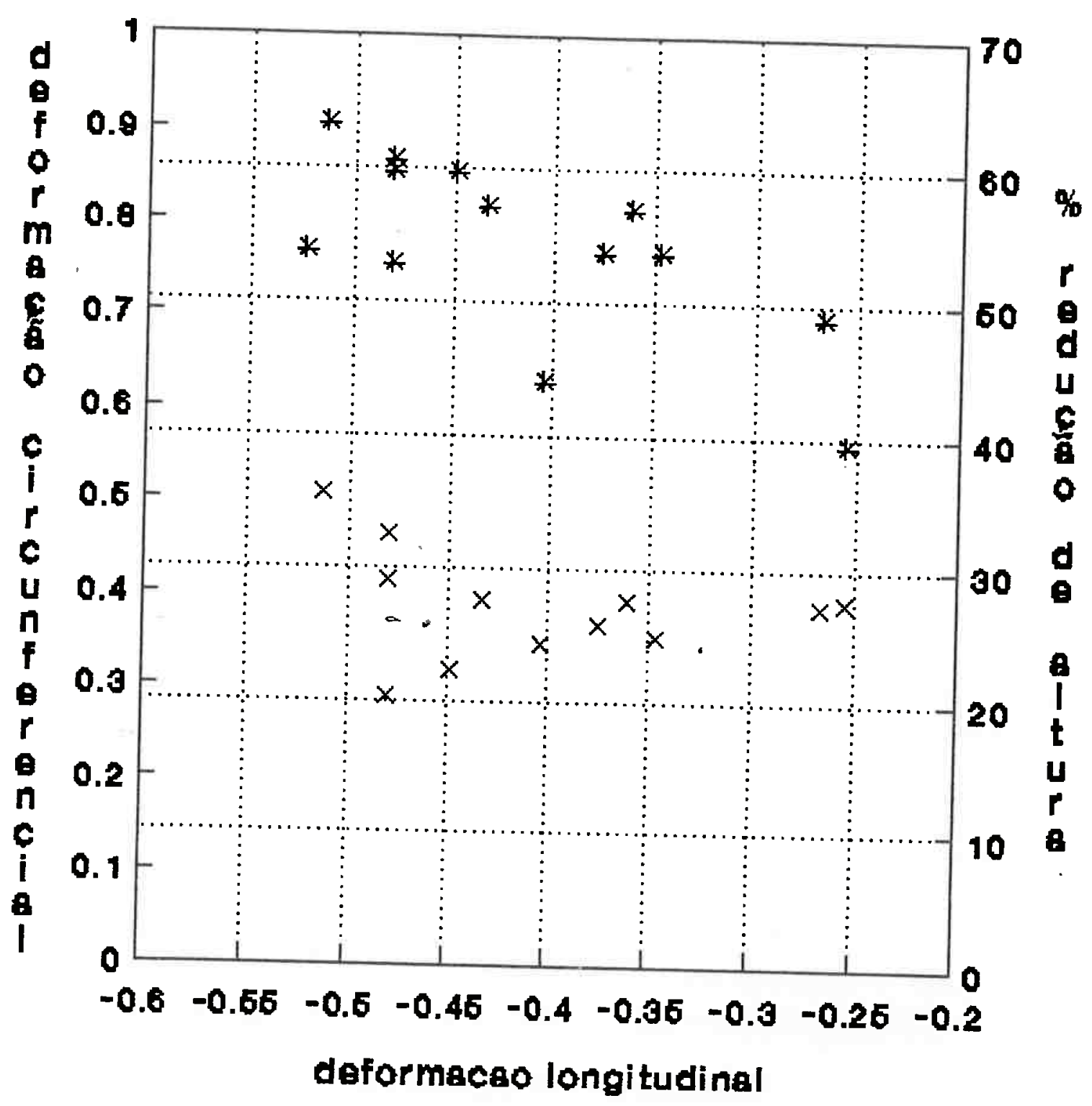

mapa de defor mapöes

$\times$ experimental * redupão

Figura 6.7 Mapa de deformações para $\circ$ caso de ausência de lubrificação na interface êmbolo-corpo de prova coeficiente de atrito $\mu=0,319$ 


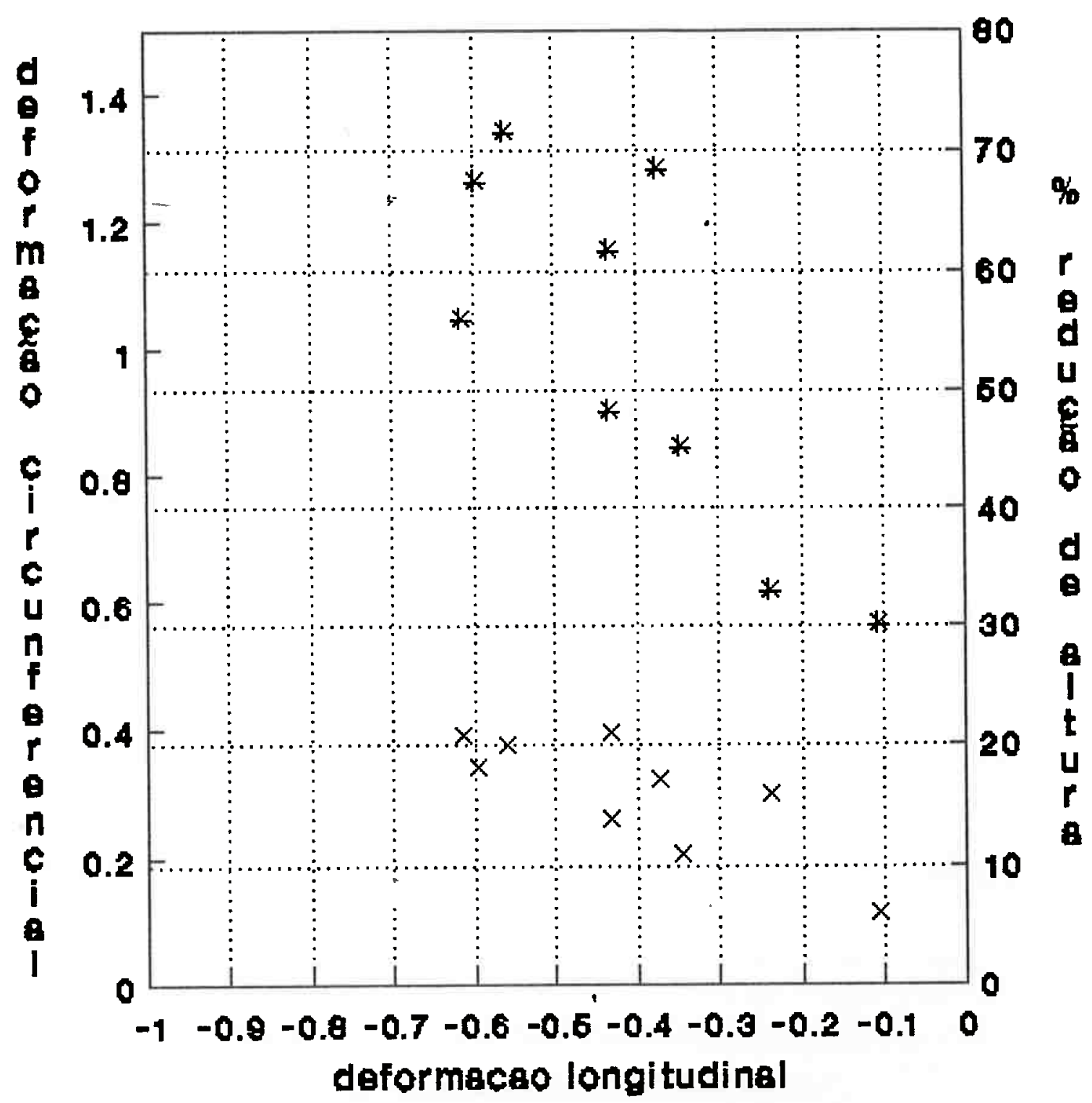

\section{mapa de defor macóos \\ $\times$ experimental * redução}

Figura 6:8 Mapa de -deformações parạ 0 caso da presença de lubrificação na intercace êmbolo-corpo de prova com óleo lubrificantè SAE 20W-40, classe SF coeficiente de atrito $\mu=0,033$ 


\section{REFERENCIAS BIBLIOGRAFICAS - Capitulo 6}

1. ASTM-E9-81 Standard methods of compression testing of metallic materials at room temperature, 1983. Annual Book of ASTM Standärds, part 10, 1983. pp.140-152

2. LEE, P.W. \& KHUN, H.A.Cold upsettesting. In:DIETER, G.E. (ed.)Workability Testing Techniques. Metals Park, $\mathrm{OH}$, American Society for Metals, 1984. pp.37-50

3. KUDO,H. and AOI, K. Effect of compression test condition upon fracturing of a medium carbon steel - study on cold-forgeability test: part II.Journal of the Japan Society of Technical Plasticity, 8:17-27, 1967.

4. THOMASON, P.F. Tensile plastic instability and ductile fracture criteria in uniaxial compression tests. International Journal of Mechanical Science, 11:187-198, 1969.

5. KOBAYASHI, S. Deformation characteristics and ductile fracture of 1040 steel in simple upsetting of solid cylinders and rings.Transactions of the ASME, Journal of Engineering for Industry, $\underline{92}(2): 391-399$, May 1970 .

6. KHUN, H.A.; LEE, P.W. and ERTURK, T. A fracture criterion for cold forming.Transactions of the ASME, Journal of Engineering Materials and Technology, Oct. 1973. pp.213-218

7. JENNER, A. and DODD, B. Cold upsetting and free surface ductility. Journal of Mechanical Working Technology, 5:31-43, 1981 .

8. MALE, A.T. and COCKCROFT, M.G. A method for the determination of the coefficient of friction of metals under conditions of bulk plastic deformation. Journal of the Institute of Metals. 93:38-46, 1964/1965. 
9. MALE, A.T. The friction of metals undergoing plastic deformation at elevated temperatures. Doctor of Philosophy Thesis, University of Birmingham, oct. 1962. pp.38a.

10. RICHARDSON, G.J.; HAWKINS, D.N. and SELLARS, C.M. Worked examples in metalworking. The Institute of Metals, London, 1985.

11. HOLMAN, J. P. and GADJA JR, W.J. Experimental methods for engineers. Third Edition, McGraw-Hill, New York, 1978.

12. JENNRICH, R.I. Noṇlinear regression in: BMDP statistical software 1981. University of California, Berkeley, 1981. pp. $290-343$.

13. RAMBERG, W. and OSGOOD, W. Description of stress-strain curves by three parameters, NACA TN 902, Jul, 1943.

14. HOLLOMON, J.H. Tensile deformation. Transactions of AIME, 162, 1945, pp. 268-290.

15. ASTM, E813-81, standard Test Method for $J_{\text {Ic }}$ a Measure of Fracture Toughness, 1988. Annual Book of ASTM Standards. Section 3, volume 03.01. Metals Test Methods and Analytical Procedures, American Society for Testing and Materials, Philadelphia, PA, 1988. 


\section{RESUltados e ANálise dos RESUltados}

Para a aplicaçãó do modelo de ensaio da conformabilidade pela mecânica da fratura não-linear, os seguintes procedimentos foram observados:

a) análise da composição 'e da microestrututa do material d ensaio com a finalidade de sua caracterização para os estudos da fratura dúctil, tabela 6.1;

b) determinação experimental dos parâmetros necessários para as expressões de HOLLOMON e de RAMBERG-OSGOOD ${ }^{1}$, cujos valores foram determinados pelo programa computacional BMDP-3PR, desenvolvido por JENNRICH ${ }^{2}$ na Universidade da California e processado no computador UNISYS B-7900 da Universidade de são -Paulo, cujos resultados são mostrados na tabela 6.2;.

c) determinação dos coeficientes de atrito de CoULOMB, obtidos pelo ensaio' do anel proposto por MALE e COCKCROFT $^{3}$, cujo diagrama é mostrado na figura $6.3 \mathrm{e}$ valores obtidos estão tabulados na tabela 6.3;

As figura 6.4 e 6.5 mostram os valores da carga teórica obtida pela equação 6.1 e da carga experimental lida no mostrador da máquina de ensaio de compressão. Ambas as cargas estão representadas em função do deslocamento do êmbolo e da porcentagem de redução de altura do cilindro de teste. A utilização da equação 6.1 visou a determinação da capacidade de carga necessária para a seleção da máquina de ensaio para a realização dos experimentos.

As dimensōes do corpo de prova são mostradas na figura 6.6, 
sendo que as deformações localizadas foram obtidas por medições diretas das grelhas gravadas nas superficies dos corpos de provas, como é mostrado na figura 6.1 .

o corpo de prova utilizado é o do tipo representado pela figura 6.2a e o mesmo é pertencente à familia de corpos de provas idealizados para os ensaios de conformabilidade plástica de processos do tipo compressivo. Essa familia de ensaios é tambem mostrada $\overline{n a}$ figura $6 . \overline{2}$.

As figuras 6.7 e 6.8 apresentam os mapas experimentais das deformações em função da porcentagem de redução de altura dos corpos de provas. Esses tipos de mapas representam os resultados muito utilizados na literatura técnica e sua importância é discutida em DIETER ${ }^{4}$.

Para as duas condições de atritos ensaiadas, observa-se que existe uma grande dispersão nos resultados dos ensaios. A razão principal é a extrema dependência do modo de fratura dúctil da microestrutura constituinte dominante no material de ensaio. As fraturas típicas encontradas nos ensaios, cujos corpos de provas estão rep̄resentados em̃ iseus estágios típicos de deformação pela figura 7.1 , são mostradas nas figuras 7.2 e 7.3 que apresentam as fraturas superficiais para ós tipicos corpos de provas identificados como sendo: CP5i, CP14i, CP6i e CP6f. 
a

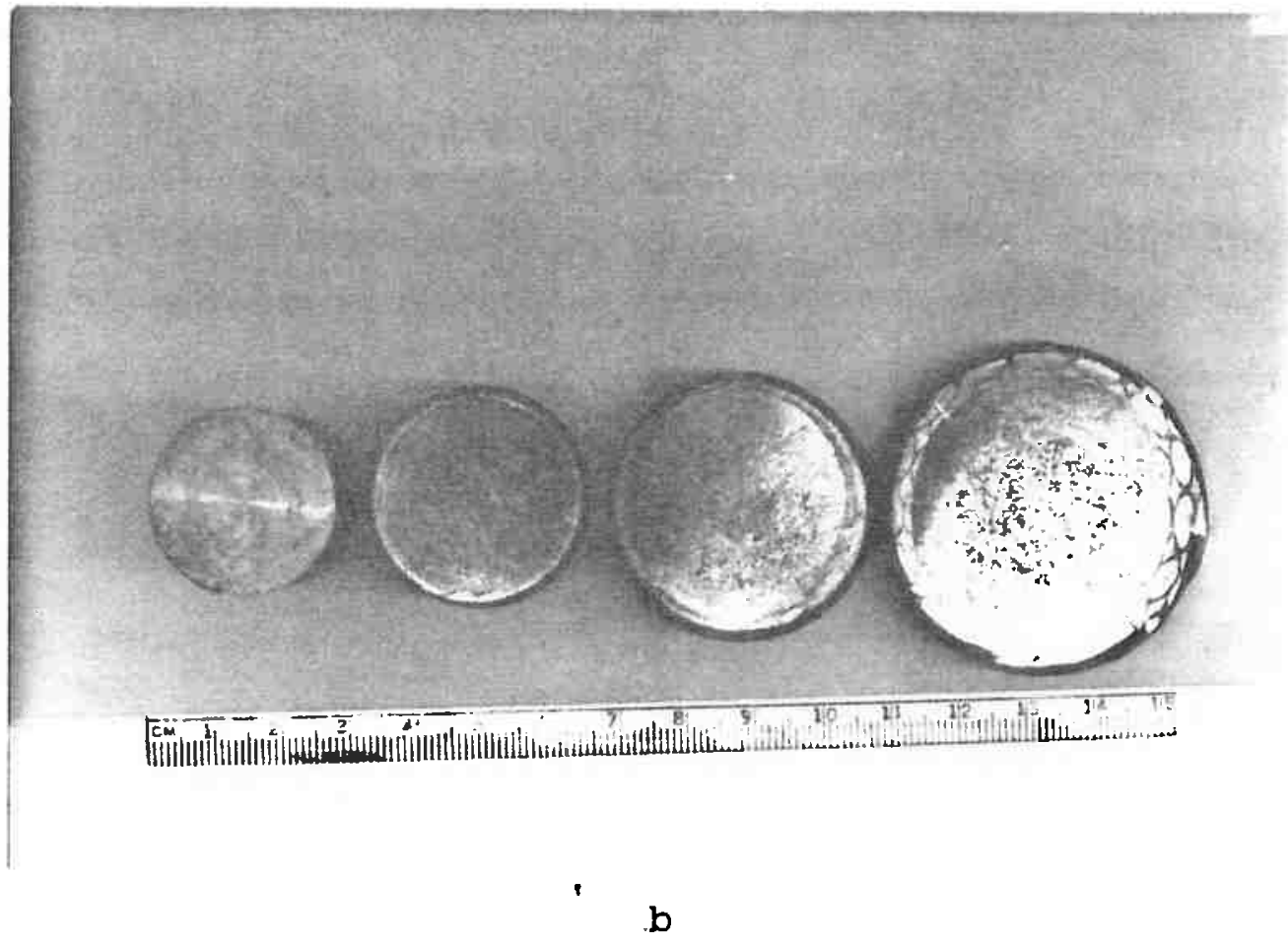

Figura 7.1 corpo de prova típico mostrando os estágios de deformações inicial, intermediários e final do ensaio de compressão em matriz aberta:

a) vista lateral

b) vista de topo 


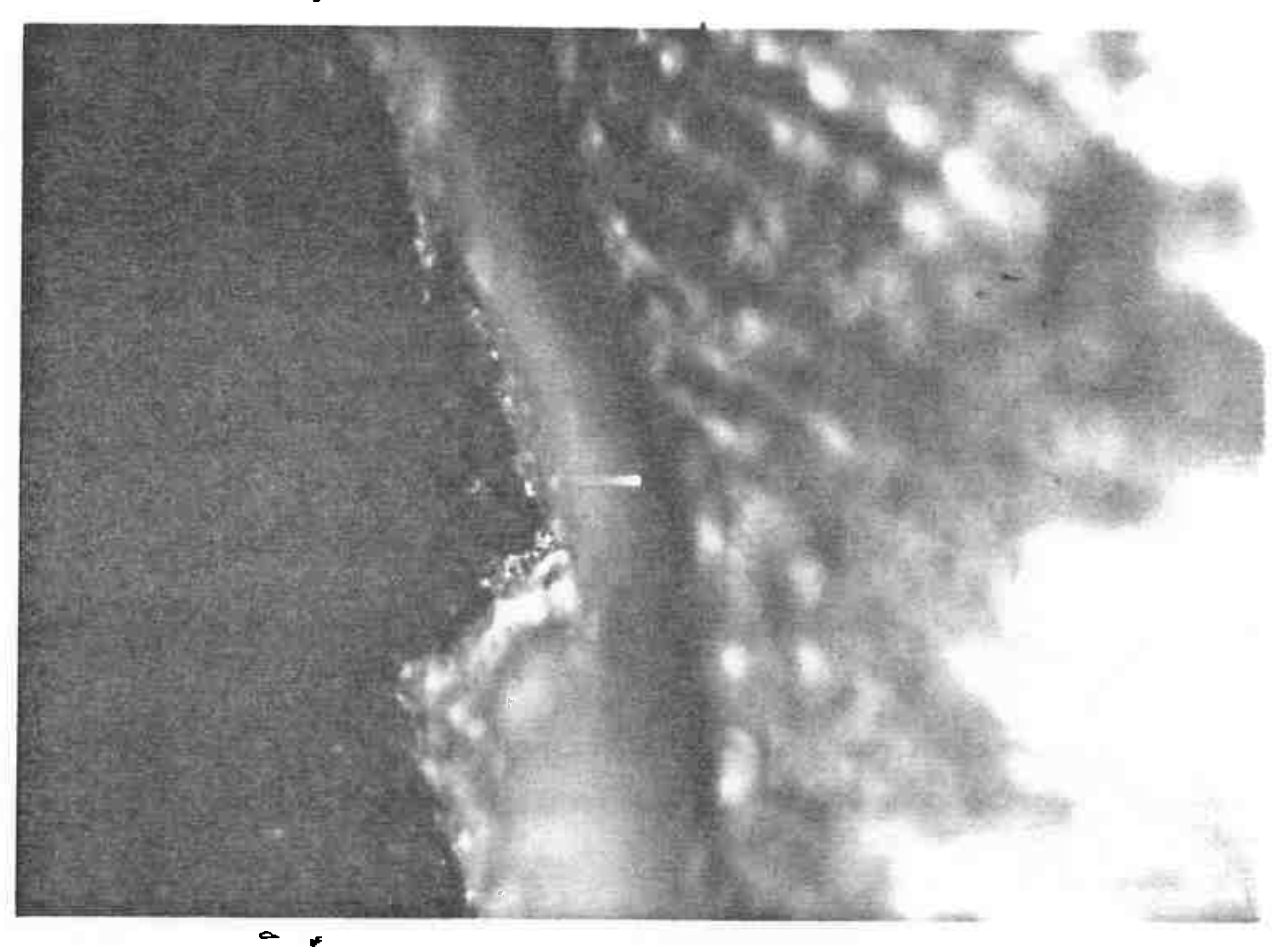

a.

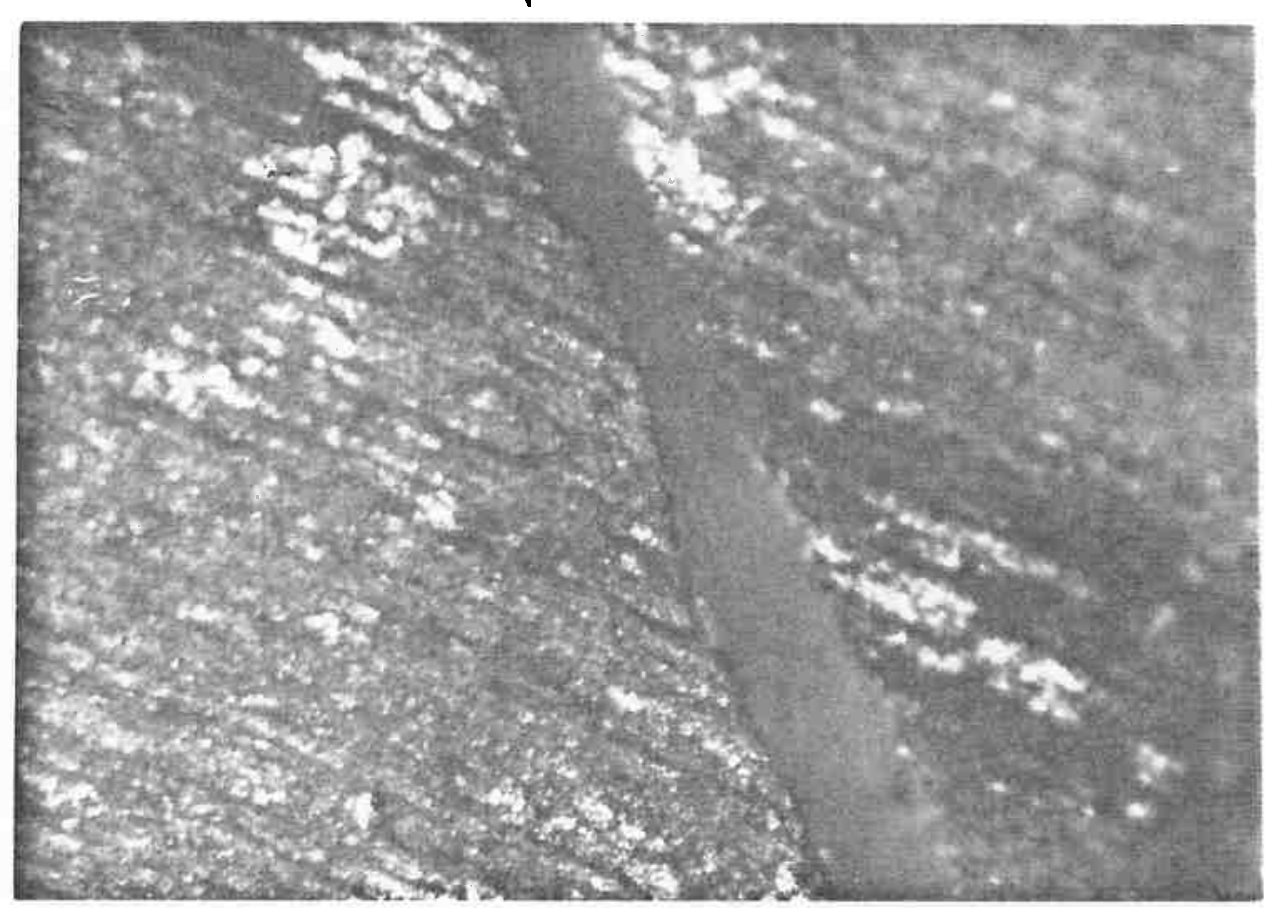

b

Figura 7.2 Fotomicrografia de corpos de provas tipicos mostrando as aberturas de trincas superficiais :

a) corpo de prova CP5i, abertura máxima

b) corpo de prova CP14i, região de estreitamento 


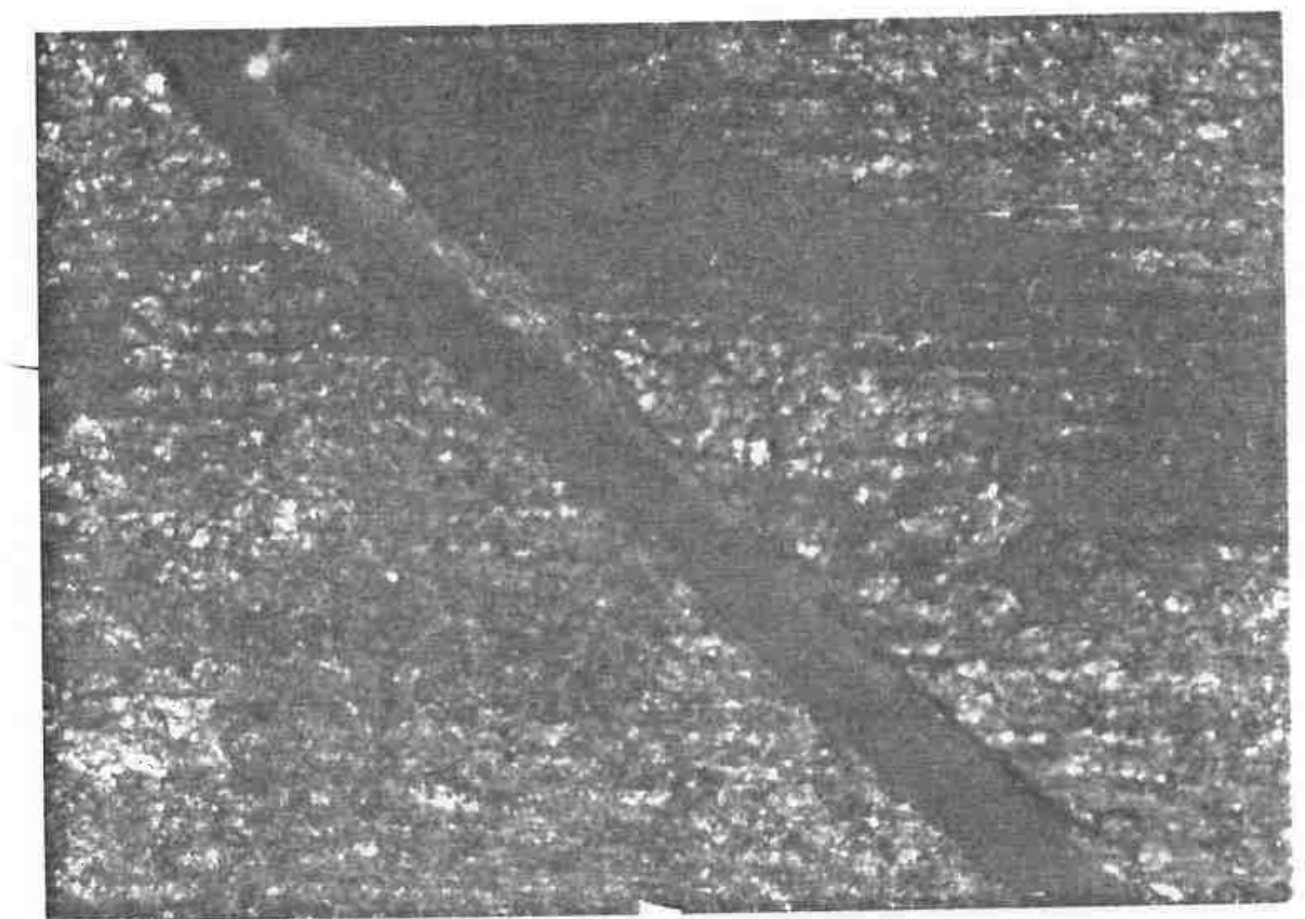

$\mathbf{a}$

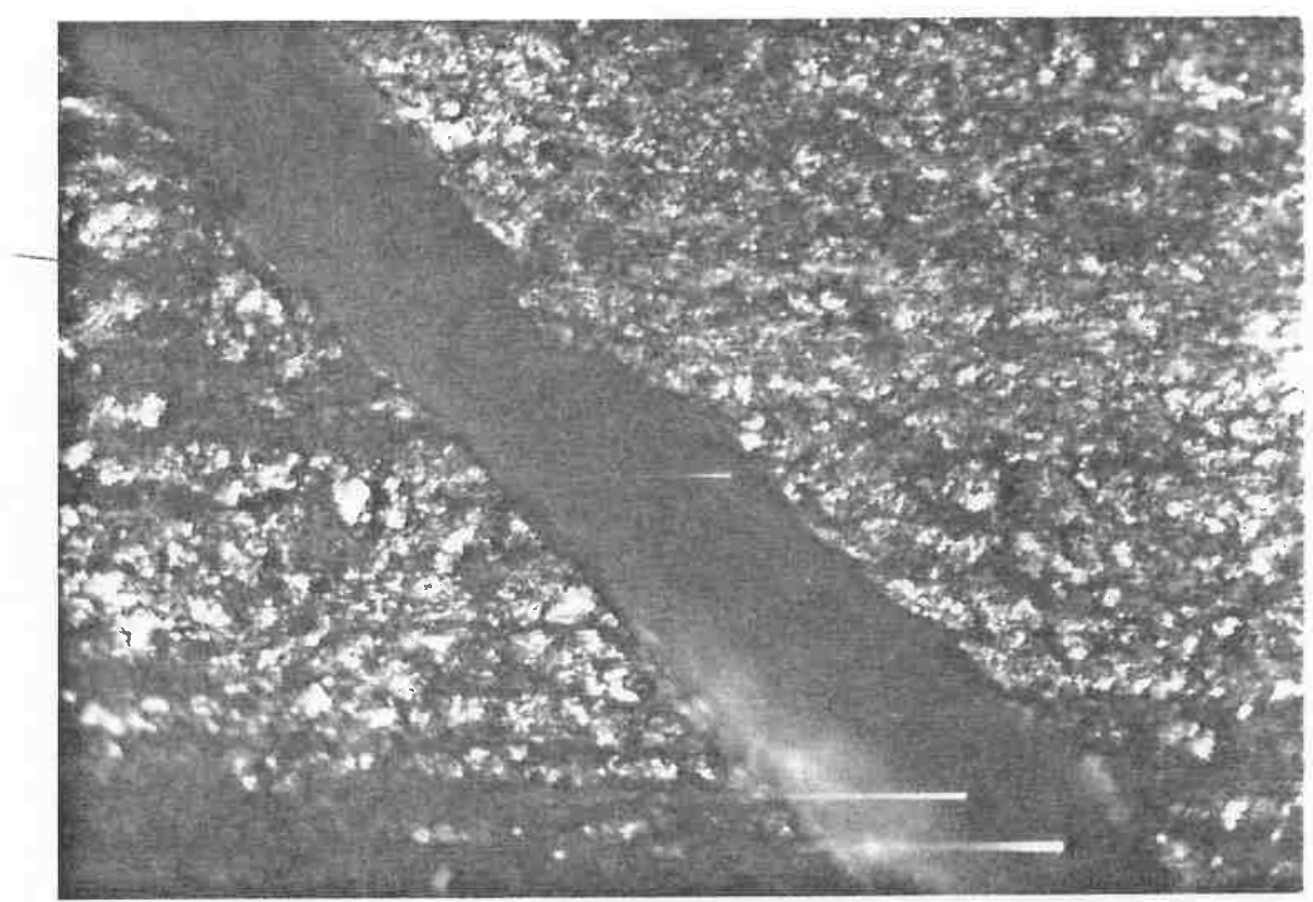

b

Figura 7.3 Fotomicrografia de corpos de provas típicos mostrando as aberturas de trincas superficiais :

a) corpo de prova CP6i, região de abertura máxima

b) corpo de prova CP6f, região de abertura máxima 
As tabelas 7.1 e 7.2 mostram os valores necessários para construção das figuras $7.4,7.5$ e 7.7 pelo uso das integrais invariantes da mecânica da fratura não-linear elasto-plástica. os mapas de conformabilidade plástica representados pelas figuras 7.5 e 7.6 . mostram que os menores valores da integral- $\hat{J}$ são os críticos e convergem para um único par de valores de deformações que formam um critério fortemente discriminador nos diagramas. o valor critico da integral-j é o fornecido pelo processo mais severo' de conformação plástica, representado pelo ensaio de, compressão com ausência de lubrificante na interface matriz-obra. A integral- $\hat{J}$ nessa condição de severidade de processo de compressão plástica pode ser considerada como um parâmetro característico do processo de conformação plástica.

Os valores da integral-j, definida pela equação 4.50 , foram obtidos pela expressão 4.54 baseado na expressão variacional $3.122 \mathrm{a}$ e pela equação geral 3.38 . 
票

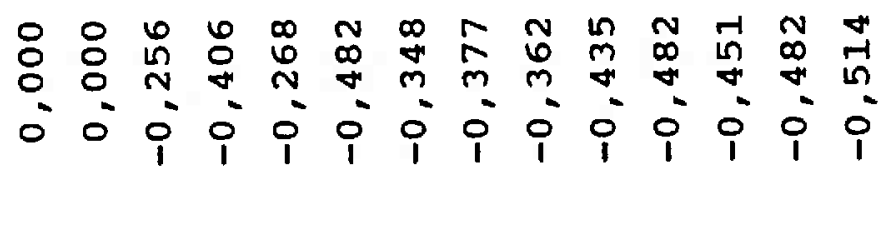

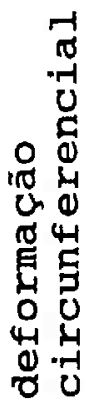

焉

芯

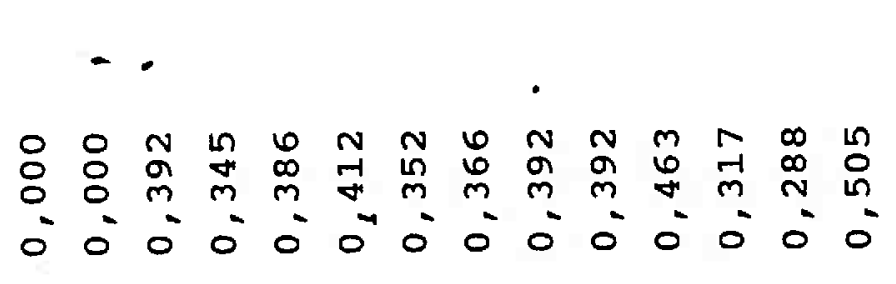

$\stackrel{0}{0}$

-

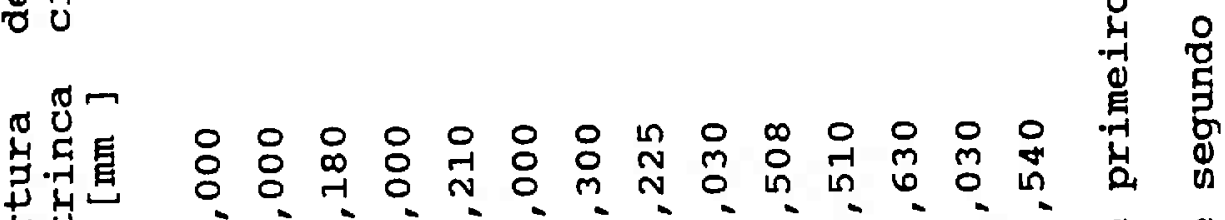

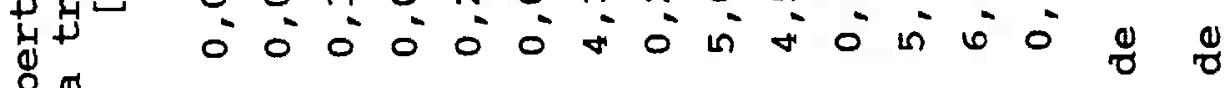
要

点:

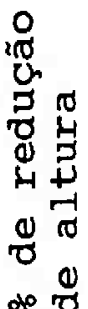

웅울

임

क्ष

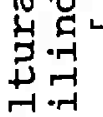

तु

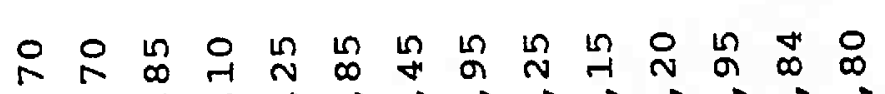

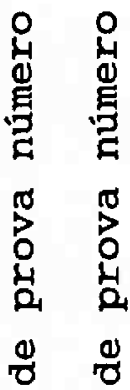
向

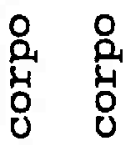

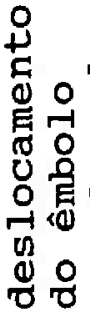

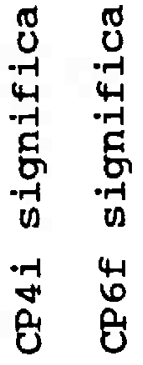

焦

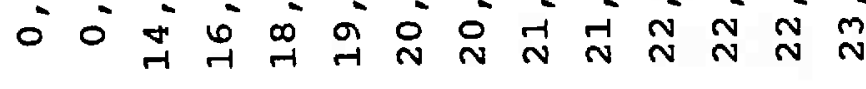

$\underset{\infty}{+1}$

Q)

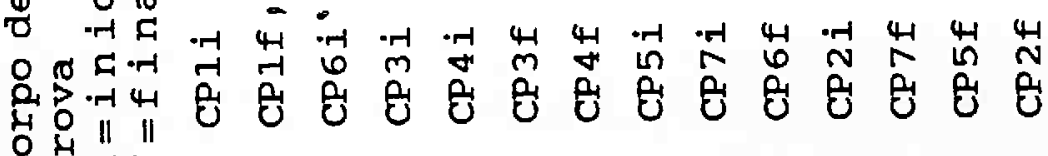




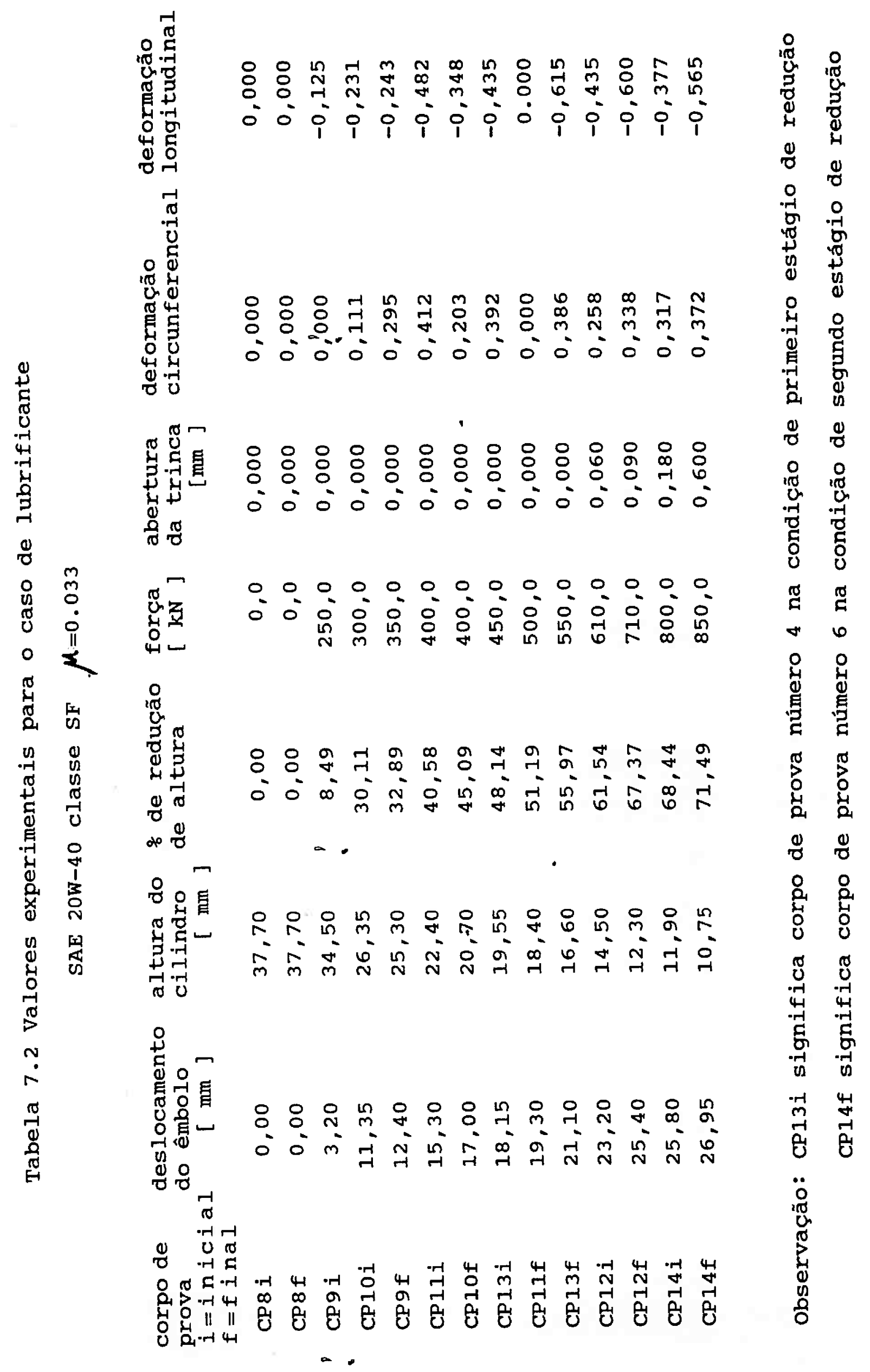


As deformações correspondentes aos valores críticos da integral- $\hat{J}$ foram obtidas através das rełações $5.28 \mathrm{~b}$, considerando a maior severidade possivel de deformação plástica que é o estado de deformação plana, com o auxílio das figuras $5.2 a$ e 5.3 , sendo que o valor radial r-foi relacionado à condição de abertura de trinca expressa pelas equações $5.30,5.31 a$ e 5.32 . 


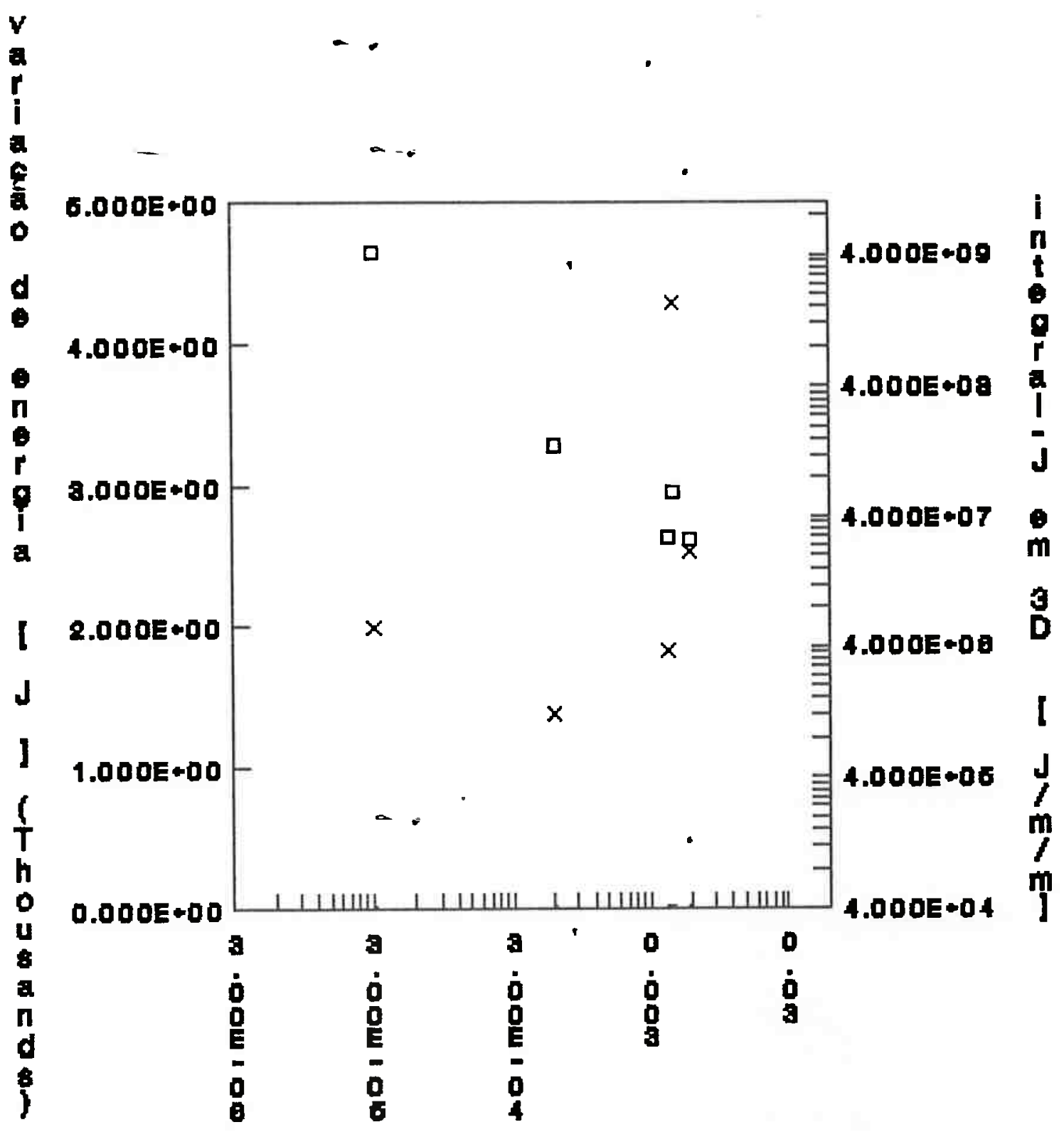

variaçäo abertura da trinca $[\mathrm{mm}]$

\section{mapa das varlap бes}

- var. abert. trinoa $X$ varlapio energla

- Intogral-d / aD

Figura 7.4 Mapa da variação de energia e da integral- $\hat{\jmath}$ na condição de atrito a seco $\mu=0,319$ em função da variação da abertura da trinca 

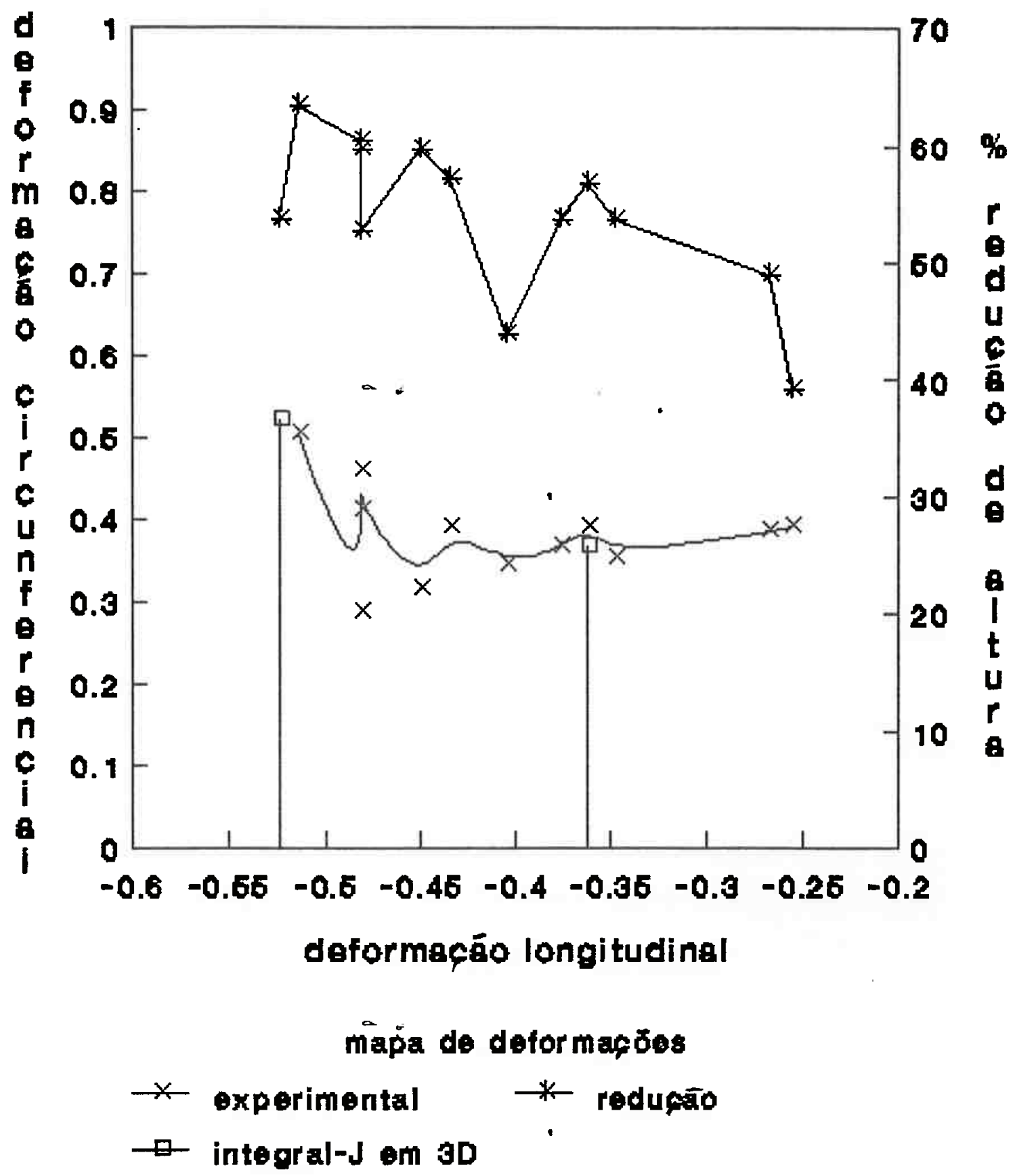

Figura 7.5 Mapa de conformabilidade plástica na condição de atrito a seco $\mu=0,319$, relacionando deformações e porcentagem de redução de altura. Os símbolos se referem à presença de trincas 

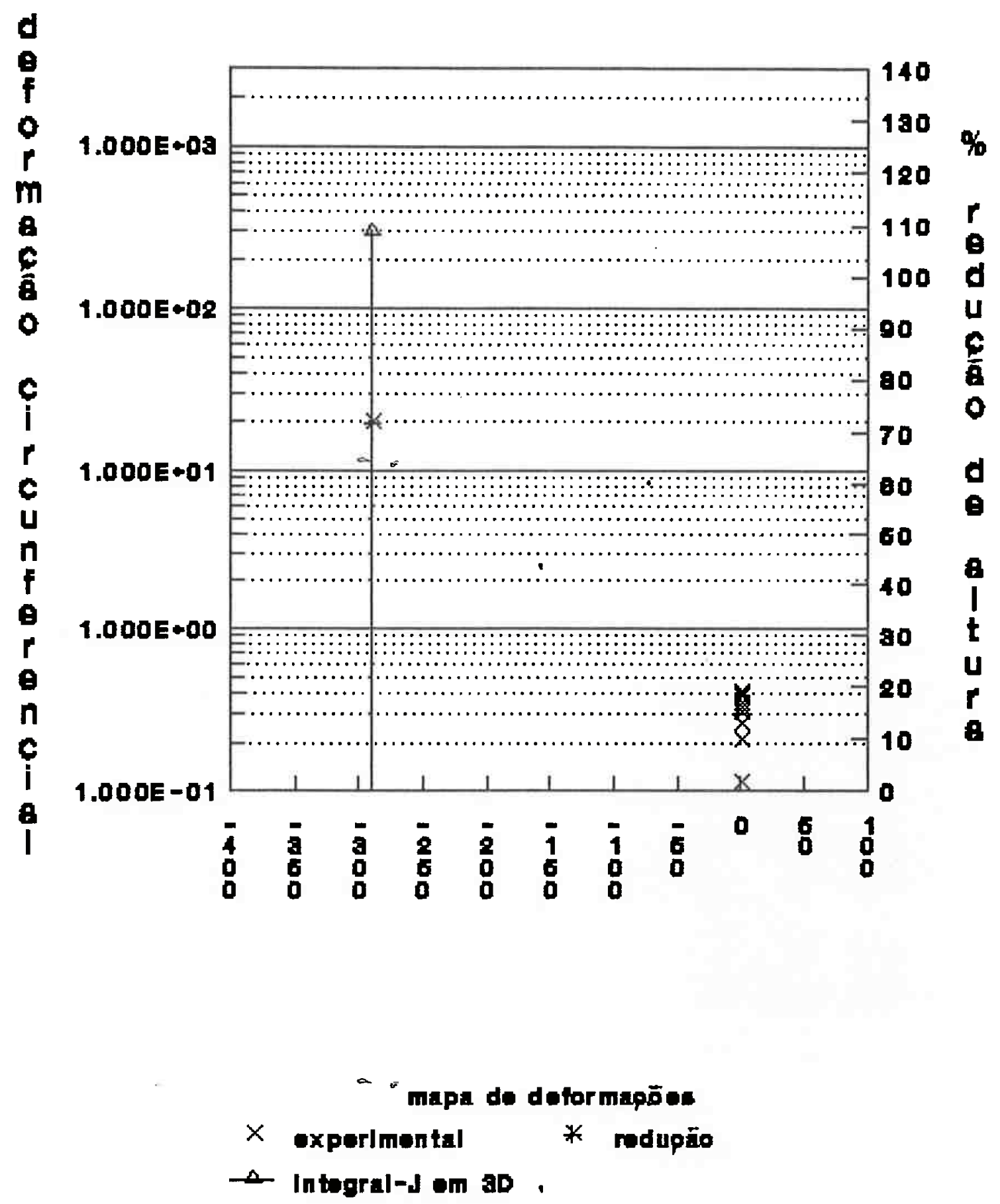

Figura 7.6 Mapa de conformabilidade plástica na condição de atrito lubrificado SAE $20 \mathrm{~W}-40$ classe SF $\mu=0,033$ relacionando deformações e porcentagem de redução de altura. Os símbolos se referem à presença de trincas. 


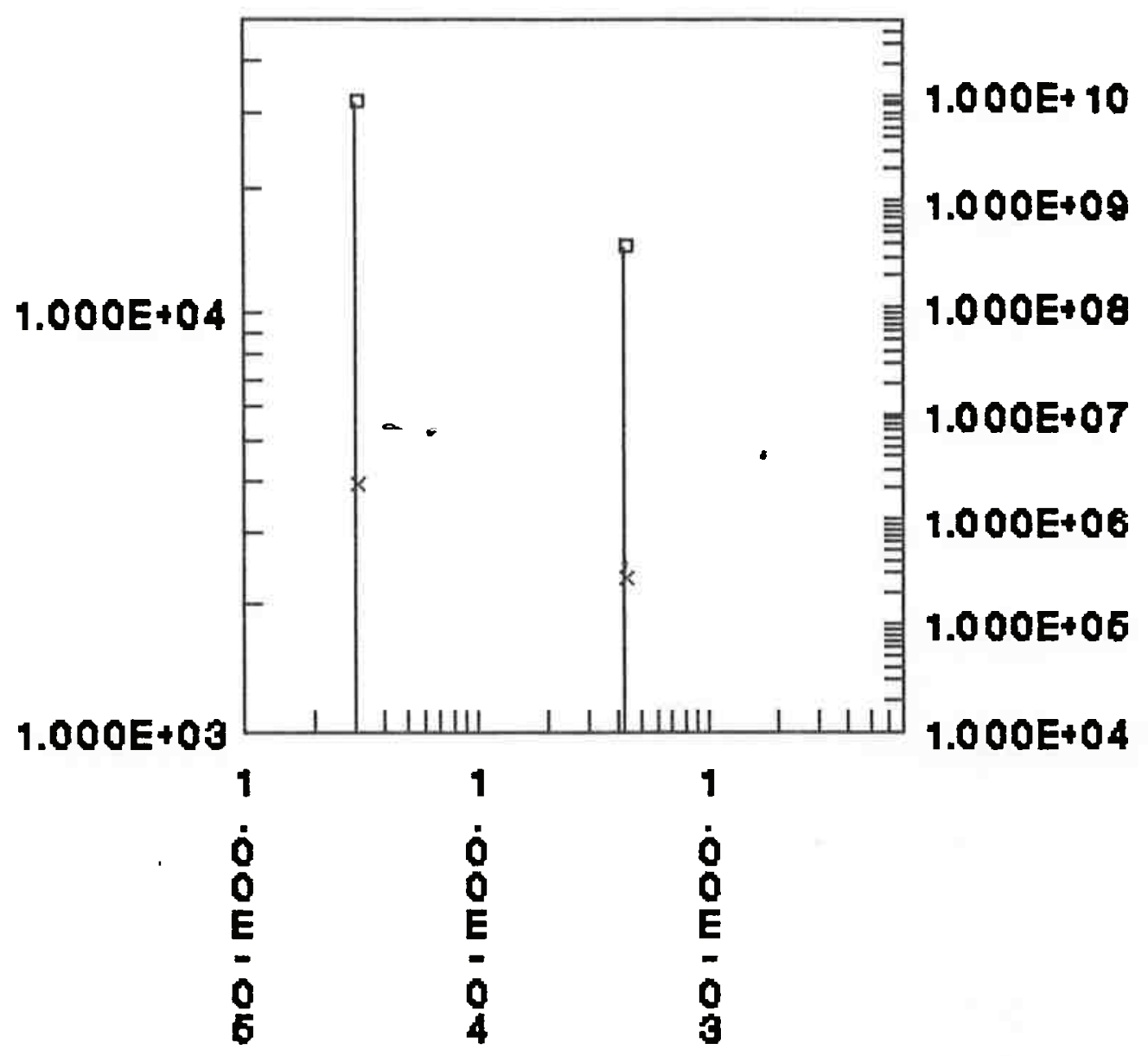

varieç̄o abertura trince var.abert.trinca

x variacta emeftiaintegral-J / aD

Figura 7.7 Mapa da variação de enérgia e da integral- $\hat{J}$ na condição de atrito com lubrificante $\mu=0,033 \mathrm{em}$ função da variação da abertura da trinca 


\section{REFERENCIAS BIBLIOGRAFICAS - Capitulo 7}

1. RAMBERG, W. and OSGOOD, W. Description of stress-strain curves by three parameters, NACA TN 902 , July 1943.

2. JENNRICH, R.I. Nonlinear regression in: BMDP statistical Software 1981. University of California, Berkeley, 1981. pp. 290-343.

3. MALE, A.T. and COCKCROFT, M.G. A method for the determination of the coefficient of friction of metals under conditions of bulk plastic deformation. Journal of the Institute of Metals. $93: 38-46,-1964 / 1965$. -

4. DIETER, G.E. (editor). Workability testing techniques. American Society for Metals. Metals Park, 'Ohio. 1984. 


\section{CONCLUSరES E SUGESTRES DE TRABALHOS}

\subsection{Conclusరes}

1) 0 método de ensaio de conformabilidade plástica, desenvolvido neste trabalho, ́resultou na construção de um mapa de conformabilidade baseado em uma integral invariante da mecânica da fratura não-linear elasto-plástica denominada de integral- $\hat{J}$, com a vantagem de que não apresenta pontos dispersos de deformações.

2) o método mostrou-se adequado para a análise das condições severas de conformabilidade representada pela ausência de lubrificação na interface matriz-obra.

3) o trabalho foi realizado por simulação experimental, através de ensaios de compressão em matrłz aberta, do forjamento a frio de um material apresentando propriedade de média ductilidade; essa propriedade permitiu a obtenção de fraturas superficiais macroscópicas de fácil deteç̧ão por meios de instrumentação óptica de baixo custo.

\section{2 Sugestores de trabalhos}

o desenvolvimento desta pesquisa contribui para o estudo de importantes problemas de conformabilidade plástica, e para tanto é importante padronização do método de ensaio proposto. Essa possivel padronização permitirá a construção de mapas de conformabilidade plástica para a maioria dos materiais metálicos em uso na industria. Cita-se como exemplo os aços carbonos comuns.

Uma pesquisa importante a ser realizada pode ser $\circ$ estudo dos 
efeitos das mais variadas condições de atritos na interface matriz-corpo de prova.

Os efeitos da temperatura de conformação no mapa de conformabilidade, construido pela mecânica da fratura não-linear, principalmente a influência do trabalho a quente no mesmo mapa é uma importante sugestão de trabalho, juntamente com os possiveis efeitos nos mapas da variação das taxas de deformações impostas nos processos de conformação.

- desenvolvimento desta pesquisa permitiu elaborar as seguintes sugestões de trabalhos futuros:

1) Estudo da padronização do ensaio proposto;

2) Costrução de mapas de conformabilidade plástica dos materiais metálicos e estudos da influência de diversas variáveis microestruturais na conformabilidade desses materiais:

3) Estudos da Influência das, condiçōes de atrito na interface ferramenta-peça na conformabilidade plástica ;

4) Estudos da influência da temperatura e das velocidades de deformações na conformabilidade dos materiais.

5) Estudo da propagação de fraturas internas caso seja possivel relacionar as deformaçöes externas mensuráveis com as propriedades invariantes das integrais- $\hat{J}$. 


\section{LISTAS DE FIGURAS E TABELAS}

\section{Figuras}

Figura 3.1. - Deformação de um corpo em função de suas coordenadas generalizadas curvilíneas:

Figura 3.2. - Incrementos de Tração nos estados original e deformado.

Figura 3.3. - Problema a ser resolvido pelo método variacional num volume V, limitado pelo contorno da superfície $\mathrm{S}$.

Figura $\overline{3.4}$. Fronteîrás de descontinuidades no campo de velocidades.

Figura 3.5. - Variação da tensão de cisalhamento em função da tensão de contato, AVITZUR ${ }^{62}$.

Figura 3.6 - Modelo de atrito de OROWAN. Separação do atrito em dois mecanismos independentes.

Figura 3.7 - Modelo de atrito de SHAW.

Figura 4.1 - Modelo de DUGDALE para fratura não-linear

Figura 4.2 Representação geométrica do campo de tensões

numa frente de trinca

Figura 4.3 Geometria para aplicação das integrais $J$ e $M$

Figura 4.4 Representâção geométrica da"região de processo de fratura

Figura 4.5 Representação esquemática de uma trinca em 3D

Figura 4.6 - Representação tridimensional de um problema de extensão de trinca.

Figura 4.7 - Configuração da frente de uma trinca e o volume para integração.

Figura 5.1 Sistema de coordenadas na ponta de uma trinca em 2D Figura 5.2a - Estruturas do modo I de trinca na deformação plana. Figura 5.2b - Estruturas do modo I de trrinca na tensão plana. 
Figura $5 . \overline{3}$ - Variação de $I_{n}$, com $n$ para tensão plana e deformação plana.

Figura 5.4 - Definição do deslocamento de abertura da trinca CoD.

Figura 5.5 - Dependência de $d_{n}$ função de $n$ e $\sigma_{0} / E$.

Figura 6.1 - Diagrama esquemático do ensaio de compressão.

Figura 6.2 - Ilustração dos estados superficiais de deformações para os ensaios (a)recalque, (b) laminação, (c)flexão.

Figura 6.3 - Diagrama para determinação do Coeficiente de atrito $\mu$, pelo ensaio de anel.

Figura 6.4 - Cargas para $\mu=0,31.9 \pm 0,050$ a seco, superficies como torneadas por faceamento de desbaste.

Figura $6 . \overline{5}$ - Cargas para $\mu=0,033 \pm 0,005$, óleo Iubrificante automotivo SAE 20W-40, Classificação API-SF.

Figura 6.6 - Dimensões dos corpós de provas, padronizadas para a realização do ensaio de conformabilidade, utilizada neste trabalho.

Figura 6.7 Mapa de deformações para o caso de ausência de Iubrificante.

Figura 6.8 Mapa de deformações para $\circ$ caso da presença de Iubrificante.

Figura 7.1 Corpo de prova típico mostrando os estágios de deformações inicial, intermediários e final do ensaio - de compressão em matriz aberta.

Figura 7.2 Fotomicrografia de corpos de provas típicos mostrando as aberturas de trindas superficiais.

Figura 7.3 Fotomicrografia de corpos de provas típicos mostrando as aberturas de trincas superficiais. 
Figura 7.4 Mapa da variação de energia e da integral- $\hat{J}$ na condição de atrito a seco $\mu=0,319$ em função da variação da abertura da trinca.

Figura 7.5 Mapa de conformabilidade plástica na condição de atrito a seco $\mu=0,319$, relacionando deformações e porcentagem de redução de altura. Os símbolos se referem à presença de trincas.

Figura 7.6 Mapa de conformabilidade plástica na condição de atrito lubrificado $\operatorname{SAE} 20 \mathrm{~W}-40$ classe $\mathrm{SF} \mu=0,033$ relacionando deformações e porcentagem de redução de altura. Os símbolos se referem à presença de trincas.

Figura 7.7 Mapa da variação de energia e da integral- $\hat{J}$ na condição de atrito com lubrificante $\mu=0,033$ em função da variação da abertura da trinca.

\section{Tabelas}

Tabela 6.1 Composição da liga UNS A92014-T6.

Tabela 6.2. Expressões do ensaio de tração da liga UNS A92014-T6. Tabela 6.3 - Determinação do coeficiente de Atrito $\mu$ pelo ensaio de anel.

Tabela 7.1 Valores experimentais para o caso de ausência de lubrificante coeficiente de atrito $\mu=0.319$.

Tabela 7.2 Valores experimentais para o caso de lubrificante SAE $20 \mathrm{~W}-40$ classe SF $\mu=0.033$. 


\section{$\cdots \quad$ APENDICE \\ FLUXO DE ENERGIA PARA O INTERIOR DE UMA REgIT̃o DE PROĆESSO DE FRATURA}

Este apêndice descreve o método de análise do fluxo de energia para o interior de uma região de processo de fratura, baseado no trabalho de $\mathrm{AOKI}^{1}$ e colaboradores.

seja um problema de propagação de uma trinca no estado tridimensional, como mostra a figura A.1, onde:

$\Gamma_{\text {final }}$ é a fronteira da região de processo $A_{\text {final }} \Gamma$ é uma curva arbitrária, que envolve a curva $\Gamma_{f \mathfrak{n a l}}, \Gamma_{\mathrm{s}}$ são curvas ao longo das superficies de trincas, A é a região regular envolvida pelas curvas $\Gamma_{,} \Gamma_{\mathrm{s}}$ e $\Gamma_{\text {final }}$. O sistema de referência é retangular fixo, com origem em 0 e centrado na ponta da trinca no instante inicial $t=t_{0}$ e com os eixos definidos em $x_{1}$ e $x_{2}$.

Na região $\mathrm{A}$ são válidas as relações da mecânica dos meios contínuos definidas pelas equação de movimento, relação de formação e deslocamento da frente da trinca, primeira e segunda lei da termodinâmica, definição de energia cinética $\mathrm{k}$ e relação entre tensão e tração superficial, respectivamente, descritas a seguir pelas relações válidas para a região A:

$$
\begin{aligned}
& =\sigma_{1, j}+F_{i}=\rho \ddot{u}_{i} \\
& \varepsilon_{1 j}=\frac{1}{2}\left(u_{1, j}+u_{j, i}\right) \\
& \rho \dot{e}=\sigma_{1 j} \dot{\epsilon}_{1 j}-q_{1,1}+\rho \gamma \\
& \rho \dot{n}=-\left(\frac{q_{i}}{T}\right)_{, 1}+\rho \frac{\gamma}{T}+\rho v
\end{aligned}
$$




$$
\rho \dot{K} \cdot=\rho \ddot{u}_{1} \ddot{u}_{1}
$$

sendo que:

$$
\text { - } T_{1}=\sigma_{1 j}-\bar{n}_{j}, \quad \text { sobre } \Gamma, \Gamma_{s} \text { e } \Gamma_{\text {final }}
$$

e:

$F_{1}$ : força de corpo

$\rho$ : densidade

$q_{i}:$ fluxo de calor

$\gamma$ : calor produzido por fontes internas

e : energia interna

$\mathrm{n}$ : entropia

$v \geq 0:$ produção de entropia

$T$ : temperatura

$\mathrm{n}_{1}$ : norma unitária sobre as curvas $\Gamma, \Gamma_{s}$ e $\Gamma_{\text {final }}$

$$
\begin{aligned}
& \dot{f}=\frac{d}{d t} f \\
& f_{, 1}=\frac{\partial}{\partial X_{1}} f
\end{aligned}
$$

Considerando, agora, uma extensão infinitesimal de uma trinca, a fronteira da região do processo é pode mover com a ponta da trinca, como na figura A.1. 


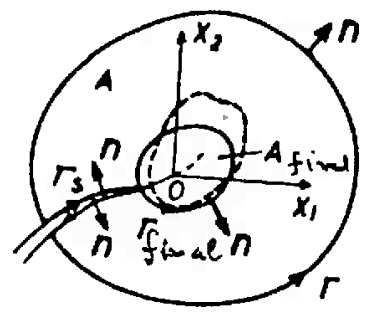

Figura A.1 - Trinca em um material elasto-plástico no caso de um problema bidimensional. AOKI ${ }^{1}$

E as equações dos balanços de energia e de entropia são representadas por:

$$
\begin{gathered}
\int_{\Gamma+\Gamma_{s}}\left(T_{1} \dot{u}_{1}-q_{1} n_{1}\right) d \Gamma+\iint_{A}\left(F_{1} \dot{u}_{1}+\rho \gamma\right) d A=\frac{d}{d t} \iint_{A} \rho(K+e) d A+\Phi \\
\int_{\Gamma+\Gamma_{s}}\left(\frac{-q_{1} n_{1}}{T} d \Gamma+\iint_{A} \rho\left(\frac{\gamma}{T}+\nu\right) d A=\frac{d}{d t} \iint_{A} \rho \eta d A+s\right.
\end{gathered}
$$

onde:

$\Phi$ é o fluxo total de energia na região de processo

S é a entropia na região de processo ou seja, s e $\phi$ são as taxas que a entropia e a energia total são absorvidas na região de processo de fratura.

Usando o teorema de Gauss e para $V_{1}$ representando a velocidade da curva $\Gamma_{\text {final }}$, obtém-se: 


$$
\begin{aligned}
& \Phi=\int_{\Gamma_{f(n a)}} \phi d \Gamma \\
& S=\int_{\Gamma} \quad s d \Gamma
\end{aligned}
$$

onde:

$$
\begin{gathered}
\phi=\rho(K+e) V_{1} n_{1}+T_{1} \dot{u}_{1}-q_{1} n_{1} \\
s=\rho \eta v_{1}-n_{1}-\frac{q_{1} n_{1}}{T} .
\end{gathered}
$$

o fluxo de energia livre $F$, a taxa na qual a energia é livre é absorvida na região de processo, é representada por:

$$
F=\int_{\Gamma \text { fna } 1}\left(\phi-T_{s}\right) d \Gamma
$$

A combinação de A.4, A.5 e A.6 fornece a expressão:

$$
F=\int_{\Gamma_{\text {final }}}\{\rho(K+f) V n+T \dot{u}\} d \Gamma
$$

f é a energia livre de HELMHOLTZ.

A velocidade de $\Gamma_{\text {final }}$, pode ser decomposta nos componentes de translação, tendo a trinca uma velocidade $v_{1}$, de rotação com velocidade angular da trinca sendo $\omega_{3} e$ expansão auto-similar a $\mathrm{x}_{1}$ e distorção $\mathrm{h}_{1}$ :

$$
v_{1}=v_{1}+e_{1 z 1} \omega_{3} x_{1}+a x_{1}+h_{1}
$$

válido para quando $t=t_{0}$,

sendo $e_{i z l} \circ$ tensor alternante. 
A velocidade de uma particula na curva $\Gamma_{\text {final }} \dot{u}_{1}$ é escrita como sendo:

$$
\dot{u}_{1}=\left.\frac{\partial u_{1}}{\partial t}\right|_{\Gamma_{\text {final }}}-\frac{\partial u_{1}}{\partial X_{j}} v_{j}
$$

Das equações A.4, A.5, A.8 e A.9, obtém-se

$$
\Phi=v_{\alpha} \hat{J}_{\alpha}+\omega_{3} \hat{\mathrm{L}}_{3}+a \hat{\mathrm{M}}+I
$$

para $\alpha=1,2$

onde:

$$
\begin{aligned}
& \hat{J}_{\alpha}=\int_{\Gamma_{\text {rinal }}}\left\{\rho(\mathrm{K}+e) \mathrm{u}_{\alpha}-\mathrm{T}_{1} \frac{\partial \mathrm{u}_{1}}{\partial \mathrm{x}_{\alpha}}\right\} \mathrm{d} \Gamma= \\
& =\int_{\Gamma_{\text {final }}} e_{131} x_{1}\left\{\rho(K+e) n_{1}-T_{j} \frac{\partial u_{j}}{\partial x_{1}}\right\} d \Gamma \\
& \hat{M}=\int_{\Gamma_{\text {final }}} \cdots x_{1}\left\{(K+e) n_{1}-T_{j} \frac{\partial u_{j}}{\partial X_{1}}\right\} d \Gamma \\
& \hat{I}=\int \Gamma_{\text {final }}\left\{(K+e) h_{1} n_{1}+T_{1}\left(\left.\frac{\partial u_{i}}{\partial t}\right|_{\Gamma_{\text {final }}} \cdot-\frac{\partial u_{1}}{\partial X_{1}} h_{j}\right)-q_{1} n_{1}\right\} d \Gamma
\end{aligned}
$$

$\hat{J}_{\alpha}, \hat{L}_{3}, \hat{M}$ e $\hat{I}$ poderão ser interpretados como os componentes do fluxo de energia total associados, respectivamente, com: translação, rotação, expansão auto-similar e distorção, sendo que $\hat{I}$ envolve, também, o termo associado com o fluxo de calor.

A aplicação do teorema de Gauss na equação A.11, fornece a expressão:

$$
\hat{J}_{\alpha}=\int_{\Gamma+\Gamma_{s}}\left(W^{e} n_{\alpha}-T_{1} \frac{\partial u_{1}}{\partial X_{\alpha}}\right) d \Gamma+\iint_{A}^{\infty}\left\{\left(\ddot{u}_{1}-F_{1}\right) \frac{\partial u_{1}}{\partial X_{\alpha}}+\right.
$$




$$
\left.+\sigma_{1\}} \frac{\partial \varepsilon_{1\}}}{\partial X_{\alpha}}\right\} d \Gamma+\int \Gamma_{f \text { inal }}\left\{\rho(\mathrm{K}+e)-\mathrm{w}^{0}\right\} \mathrm{n}_{\alpha} \mathrm{d} \Gamma
$$

onde a deformação foi decomposta na forma:

$$
\varepsilon_{1 j}=\varepsilon_{1 j}^{e}+\varepsilon_{1 j}^{*}
$$

para os seguintes parâmetros:

$\varepsilon_{1}$ é a deformação inelástica (deformação térmica ou deformação plástica)

$\varepsilon_{1 j}^{e}$ é a deformaçẽo elástica, relacionada com a tensão elástica $\sigma_{1 j}$ e a densidade de energia elástica, na forma:

$$
\frac{\partial W^{e}}{\partial \varepsilon_{1 j}^{e}}\left(\varepsilon_{1 j}^{e}\right)=\sigma_{1 \mathrm{~J}}
$$




\section{REFERENCIÄ BIBLIOGRAFICA - - Apendice}

1. AOKI, S.;KISHIMOTO, K. and SAKATA, M. Energy flux into process region in elastic-plastic fracture problems. Engineering Fracture Mechanics, 19(5):827-836, 1984. 